
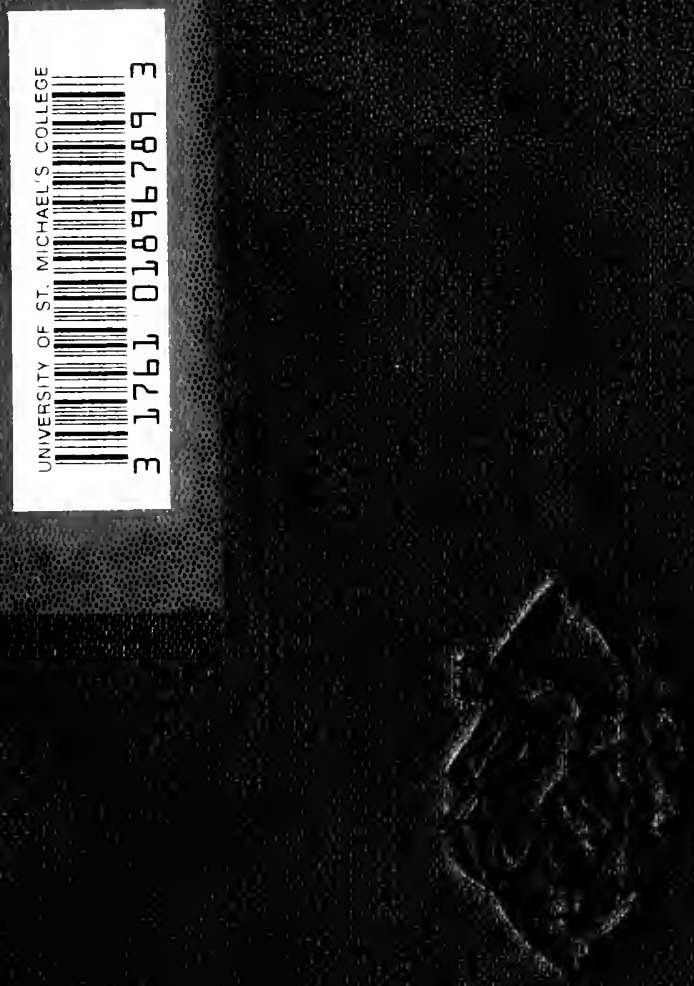



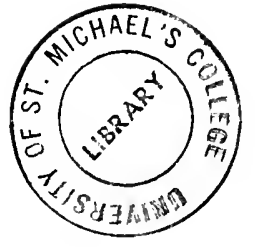



The INTERnational Critical Commentary

\section{A CRITICAL AND EXEGETICAL COMMENTARY}

uN

\section{THE PASTORAL EPISTLES}

(I \& II TIMOTHY AND TITUS)

kV

The Rev. WALTER LOCK, D.D. 

The international Critical commentary

\title{
A CRITICAL AND EXEGETICAL COMMENTARY
}

\author{
ON \\ THE PASTORAL EPISTLES \\ (I \& II TIMOTHY AND TITUS)
}

\begin{abstract}
BY
The Rev. WALTER LOCK, D.D.

2ADY MARGARET PROFESGOR OF DIVINITY IN THE UNIVERSITY OF OXFORD AND CANON OF CHRIST CHURCH
\end{abstract}

Edinburgh : T. \& T. CLARK, 38 George Street 


\section{PKINTED IN GREAT BRITAIN BY}

MORRISON AND GIBB LIMITED

FOR

1. \& C. CLARK, EDINBURGH

NEW YORK : CHARLES SCRIBNER'S SONS

FiRST IMPRESSION • . . I924

LATEST IMPRESSION . . . 1959

The Rights of Translation and of Reproduction are Reserved 


\section{JOANNI CHRYSOSTOMO \\ HERMANNO VON SODEN \\ MARTINO DIBELIO}

HARUM EPISTOLARUM INTERPRETIBUS LOCUPLETISSIMIS

HOC VOLUMEN

QUOD IIS MULTUM ACCEPTUM REFERT

GRATUS DEDICO 



\section{PREF A C E.}

THE preparation of this volume was promised some years ago, but has been delayed by the many and multiform duties of practical life which have come to the author. If there are still occasional marks of the want of that concentration on one task which is so necessary for a Commentary, there is this compensating advantage: coming back again and again to these Epistles my mind has seemed to feel a truer sense of the proportion of the various parts to each other: I feel more able to "make the salient points salient," to put the first things first.

The first purpose of the writer was, I am sure, ethical: he wanted to build up a high level of character in the Christian communities, such as would attract the outside world to Christ. "You have" (he says to his Churches) "to take your share in the life of the world around you and to attract it to Christ; you have to be good citizens, good neighbours; for this you must embody the natural virtues which the heathen world around you rates most highly, and must add to them the graces of faith, hope, and love: and this you can do, for you have the power of the Incarnate and Risen Christ to help you." To emphasize the true features of that character and the spiritual dynamic 
which would make it possible was his first aim, and should be the first aim of his commentator.

Quite subordinate to this, though important for its cfficiency, is the ecclesiastical organization. Very little is said about the duties of any grade in it; little about the method of ordination to any of them or about the relation of each grade to the rest; even the problem of the relation of the $\epsilon \pi i \sigma \kappa o \pi о s$ to the $\pi \rho \epsilon \sigma \beta \dot{v} \tau \epsilon \rho$ os only admits of a probable solution. Taking the references at their face value and assuming an early and Pauline date for the composition, it is practically certain that they are two different names for one and the same grade of ministry; but assuming a late date, say in the 2 nd century, near the time of Ignatius, when the distinction between the two was clearly marked, no reader would then have any doubt that they represented distinct grades, any more than a modern reader would have.

Subordinate also to this is the problem of the authorship on which so much careful and meticulous scholarship has quite rightly been spent hitherto. I have tried to show (p. xxxi) how truly Pauline in spirit these letters are, whoever was the amanuensis who took them down and whoever the person who dictated them; but, apart from the special reasons which apply to these lipistles, 1 cannot but think that by this time in the history of Christianity the question of authorship of almost any book of the Bible has become of only secondary importance. Every century which has borne its witness to the intrinsic value of a book has so far diminished the apologetic importance of knowing its author, and a long line of witnesses, from Ignatius in his letter to Polycarp, through the many Church Orders, 
through Chrysostom and Gregory, through Calvin and George Herbert, down to the latest treatises on pastoral or missionary work ${ }^{1}$ or the last addresses to candidates for Holy Orders, bears witness that, as long as the Church endures, these Epistles will have an abiding value, and the careful study of them will repay the student with fresh insight into their meaning and fresh guidance for building up his own character, be he layman or be he an official minister of the Church. $^{2}$

In conclusion, I have to express my warmest thanks to the Rev. Henry Austin Wilson, Fellow of St. Mary Magdalen College, Oxford, who corrected the proofs of the first half, and to the Rev. Edward Charles Everard Owen, formerly Fellow of New College, Oxford, who continued the work when Mr. Wilson was prevented by illness. To both I owe useful suggestions as well as most careful correction of the proofs.

Nor must I end without a special word of thanks

${ }^{1}$ Mr. E. F. Brown's Commentary in the Westminster Commentaries is a great proof of the value attached to these Epistles by missionaries working in India.

${ }^{2}$ Since the Introduction was in print a fresh test has been applied to the problem of the Pauline authorship. In the Journal of Theological Studies for Oct. 1923, Professor H. J. Rose has examined and classified carefully the clausula, the rhythms of the endings of the sentences, in the whole Pauline Corpus, and by comparing those in these Epistles with those predominant in the admittedly genuine Epistles, comes to the conclusion that 2 Timothy is in the main genuine, that Titus is doubtful, and that I Timothy is definitely non-Pauline. It is striking that this method of approach should lead to a result very similar to that which had been reached by other methods, and it certainly weakens the case for I Timothy. But it is very doubtful whether this rhythmical test, however applicable to set speeches, can be transferred with any confidence to informal letters: Mr. Rose has to admit exceptions to its rigid application ; and for it to be conclusive these Epistles should only be compared with the practical sections of the earlier Epistles; the more argumentative or more poetical and rhetorical sections ought not to be thrown into the scales. 
to the patience and good nature of my publishers, and to the carefulness and suggestive thoughtfulness of their compositors.

Christ Church, January 1924.

WALTER LOCK. 


\section{G ONTENTS.}

ABbreviations
INTROdUCTION





\section{ABBREVIATIONS USED IN THE COMMENTARY}

(CF. also PP. Xli-Xliv).

A.V. - . - Authorized Version of the English Bible.

Egypt. K.O. . . See Egypt. C.O.

Ambst. . . . Ambrosiaster.

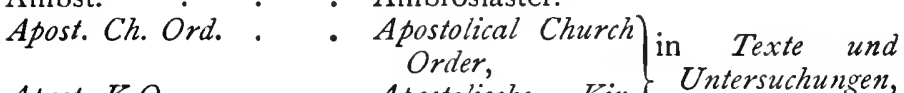
Apost. K.O. . . Apostolische Kir- $\left\{\begin{array}{l}\text { Untersuchungen, } \\ \text { ii. 5. }\end{array}\right.$ B.G.U. . . . (Berlin) Griechische Urkunden, I 895Bibl. Antig. (Philo) . The Biblical Antiquities (of Philo), ed. M. R. James, S.P.C.K., I 9 I 7.

Blass, N.T. Gr. . . Grammar of New Testament Greek, English translation, I 898 .

Brightman, L.E.W. . Liturgies Eastern and Western, Oxford, I 896.

Canones Apost. . . Canones Apostolorum (from the Apostolical Constitutions, viii. 47), ed. F. Lauchert, I 896.

Canones Hipp. . . Die Canones Hippolyti, ed. Achelis, in Texte und Untersuchungen, vi. 4 .

Clarom. . . . Codex Claromontanus.

Clem. Hom. - . - Clementis Romani Homilia, ed. Dressel, 1853 .

Const. Apost. - . Constitutiones Apostolorum, ed. P. A. de Lagarde, I 862.

Cov. . . . . Coverdale's Nere Testament.

Deissmann, B. St. . Biblical Studies, by A. Deissmann, Eng. translation, I90I.

Deissmann, L.A.E. Light from the Ancient East, by A. Deissmann, Eng. transln., I 9 Iо.

Dict. Chr. Ant. ～. Smith and Cheetham, The Dictionary of Christian Antiquities, I 875-80. 
Dittenberger, Syll

Egypt. C.O. .

Encycl. Brit.

Fuld.

Geneva

H.K.

Hand $C$.

H.D.B.

I.C.C. .

I.G.

IIl. Bible Dictn.

Inscr., Cagnat

J. Th. St.

K.O

M.M.

McGiffert, $A . A$.

Moffatt, L.N.T.

Moulton, Gr. N.T.

N.T. in Afost. Fathers .

Nägeli .

O.G.I.S.

O.L.

Orelli, Inscr.

Orelli, Henz.

P.B.

Pat. Eleph.

Pap. Oxyr.
Sylloge Inscriptionum Grecarum, ed. W. Dittenberger, I 888.

Egyptian Church Order, ed. Connolly, in Texts and Studies, viii. 4 .

Encyclopadia Britannica, 1899-1903.

- Codex Fuldensis.

- The Geneva New Testament, 1557.

- Hand Commentar zum N.T., vol. iii., Freiburg, I89I.

Dictionary of the Bible, ed. J. Hastings, 1898-1904.

International Critical Commentary.

Inscriptiones Grace, Berlin, I873-

Murray's Illustrated Bible Dictionary, ed. W. C. Piercy, r 908.

Inscriptiones Grack, ad res Romanas pertinentes, ed. R. Cagnat, Paris, 19I I-

The Journal of Theological Studies, London, I9IC-

Kirchen-Ordnung. See Apostol K.O.

The Vocabulary of the Greek Testament, by J. H. Moulton and G. Milligan, 1914-

History of Christianity in the Apostolic Age, by A. C. McGiffert, 1897 .

Introduction to the Literature of the $N . T$., by J. Moffatt, rgir.

A Grammar of N.T. Greek, by J. $\mathrm{H}$. Moulton, 1906-

The New Testament in the Apostolic Fathers, Oxford, 1905.

Das Wortschatz des Apostel's Paulus, von T. Nägeli, 1905.

Orientis Graci Inscriptiones Selecta, ed. W. Dittenberger, 1903-5.

Old Latin Version.

Inscriptiones Latina Selecta, I. II., ed. J. E. Orelli, I 828 .

Inscriptiones Latince Selecta, III., ed.

IV. Henzen, 1856 .

Die Pastoral Briefe.

Elephantine Papyri, ed. C. Rubensohn, Berlin, I907.

The Oxyrhynchus Papyri, ed. Grenfell and Hunt, vols. i. -xv., London, I 898- 
Pap. Paris . . . Paris Papyri, ed. Brunet de Presle, Paris, 1865 .

Pap. Tebt. . . . The Tebtunis Papyri, ed. Grenfell, Pirke Aboth. . . The Sayings of the Jezoish Fathers, ed.

Pss.-Sol . . . The Psulms of Solomon, ed. Ryle and James, r89r.

R.V. • . . - Revised Version of the English Bible.

S.-H. . . . . The Epistle to the Romans, by Sanday and Headlam, in the I.C.C.

Schürer, H.J.P. . . A History of the Jeweish People in the si v.l. . . . . si vera lectio.

Souter. . . Novum Testamentum Grace. Textui a Retractoribus Anglicis adhibito brevem adnotationem criticam sub. jecit, A. Souter, Oxford, 19 Io.

T. und U. . . . Texte und Untersuchungen zur Geschichte der Altchristlichen Literatur, von Gebhart und Harnack, Leipzig, I 882-95.

T. und U.N.F. - . Texte und Untersuchungen Neue Folge, I $896-$

Test. Dom. Nostri . The Testament of Our Lord, ed. Cooper and Maclean, 1902.

Test. XII Patrum . The Testaments of the Twelve Patriarchs (Greek Version), ed. Charles, I 908.

Texts and Studies. . Ed. J. Armitage Robinson, Cambridge, I 89 I-

Tischdf. • . . Novum Testamentum Grace, ed. C. Tischendorf and C. R. Gregory, ed. octava, I 894 .

Trench, Syn. - . Synonyms of the Nere Testament, by Archbishop Trench, 8th edition, 1876.

Tynd. . • . . Tyndale's Nerw Testament, I 534 .

W.-H. . . . . The New Testament in Greek, with Introduction and Appendix, by Westcott and Hort, Cambridge, I $88 \mathrm{I}$.

Zahn, Einl. . . . Einleitung in das Neue Testament, von Theodor Zahn, I897-09.

Zeitschr.N.T. Wissenschaft Zeitschrift fïr die neutestamentliche Wissenschaft, Giessen, I 900- 



\section{INTRODUCTION.}

NamL.-These Epistles were from the first separated from the letters to the churches as part of a group of private letters to friends, written "pro affectu et dilectione": as such they are, in the Muratorian Canon and in all MSS., classed with Philemon. But they were soon separated from it, as having a bearing on church life (Canon Mur. " in honore tamen ecclesiæ catholicæ in ordınationem ecclesiasticæ disciplinæ sanctificatæ sunt." Tert. adv. Marc.v. 2 I "ad Timotheum duas et unam ad Titum de ecclesiastico statu compositas"); and Marcion, while accepting Philemon, rejected them. The earliest reference to a common name for them is found in the $\mathrm{I} 7$ th century, "qua Pontificiae vocari solent" (Cosmas Magalianus, Lugduni, 1609); and from the 18 th century the title "Pastoral," suggested first by P. Anton in 1726, soon became a recognized title in Germany; .cf. Michaelis, Einleitung, I 777, "die so-genannten Pastoral-briefe" (cf. Wohlenberg, p. 68; Zahn, Einleitung, i. 444 ; Harrison, pp. I3-16), and has since gained universal currency.

Unity of purpose.-This title well describes them, though in rather different degrees : I $\mathrm{Ti}$ is entirely pastoral, and perhaps intended to be of universal application; Titus is mainly pastoral, but also a letter of commendation and a letter of recall; $2 \mathrm{Ti}$ is mainly personal, a letter of recall, and only incidentally pastoral; yet all may be for many purposes treated as a unity. For the main purpose of them all is the same; it may be summed

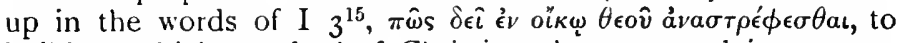
build up a high standard of Christian character and intercourse in the Church as the family of God, or in those of Tit $2^{12-13}$ (of the purpose of the Incarnation and Atonement), to enable men

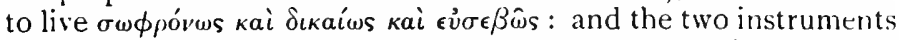
which are to achieve this aim are the same in all--a high standard of character and loyalty to the Apostolic teaching.

The Chrisilan Character. - The secret of the character is a personal relation to Christ as one who had lived a human life, and is now a Risen and Ascended Lord ( $\left.\mathrm{I} 3^{16}\right)$, a constant 
remembrance of Him as a Risen Lord able to help (II $\left.2^{8}\right)$ : a constant expectation, nay, a whole-hearted desire (áám $\eta$ ) for His Returning Presence ('Tit $2^{13}$, II $4^{8}, \mathrm{I}^{14}$ ): for He is the mediator between man and a God of life ( $\mathrm{I}_{4}{ }^{10}$ ), a God who has made all creation good (I $\left.4^{4}\right)$, and who wishes all men to be saved $\left(\mathrm{I}^{4}\right)$;

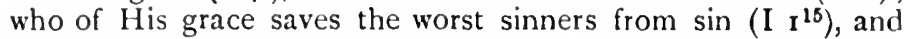
brings them back to share His own glory (I I $\left.{ }^{11}\right)$. Man's attitude towards God is expressed in the Pauline triad, faith $\left(\mathrm{I}_{1}^{4.14} 2^{15} 4^{12}\right.$, 'Tit $3^{15}$ ), love $\left(\mathrm{I}_{1^{5.14}}\right)$, and hope (I $\mathrm{I}^{1} 4^{10} 5^{5} 6^{17}$, II $4^{8}$, Tit $\left.\mathrm{I}^{2} 3^{7}\right)$. His ideal is to live a quiet and peaceable life in a religious and serious spirit (I $\mathbf{2}^{2}$, cf. II $\mathbf{2}^{22}$ ) : his essential characteristics are sincerity, a good conscience, a pure heart; he models himself on the Divine qualities of goodness and loving-kindness (Tit $3^{4}$ ); he receives power from Christ: hence he holds himself well in hand

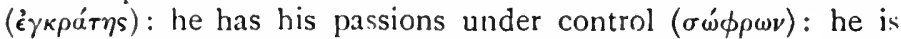
content with little (I $6^{7.8}$ ): he is sober-minded ( $v \eta \phi a ́ \lambda$ ios: cf. $v \eta^{\prime} \phi \epsilon \iota$, II $4^{5}$; $\alpha v \alpha v \eta^{\prime} \phi \epsilon \iota v^{\prime}$, II $\left.2^{26}\right)$ : his virtues are kept healthy, fret. from any feverish excitement (iviaive ${ }^{2}$, Tit $2^{2}$; $c f$. I $6^{4}$ ) : he avoids profitless discussion and speculations $\left(\mathrm{I}^{4} 6^{3}\right)$. Hence he is prepared for every good work, ready to be used by his Master at a moment's notice ( vै $\left.\chi^{\prime} \eta \eta \sigma \tau o s\right)$ : he lives a life useful to his

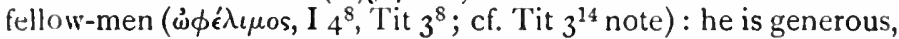
if he has wealth (I $\left.6^{17-19}\right)$ : he is careful of justice to others

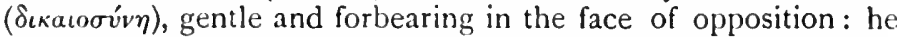
is not content with merely good works, he aims at excellence

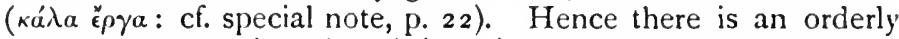
beauty about all his actions (кó $\sigma \mu c o s)$ : they adorn the teaching he has received (Tit $2^{10}$ ): nay, there is a religious dignity ( $\sigma \epsilon \mu \nu$ ćt $\left.^{\prime}\right)$ that marks him out: he moves through life as though it were a

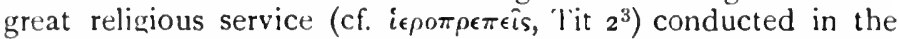
sight of $G$ i)d and of Christ (I $5^{21} 6^{13}$, II $2^{15} 4^{1}$ ), with the hope that his life may attract outsiders to share the joy of the procession. This type of character is to be exhibited in family life (for the family is the type of the Church, I $3^{5} 5^{1}$ ): in a high conception of marriage ( $\mathrm{I}^{15} 4^{3} 5^{14}$ ), in fidelity of husband to wife and wife to husband, in the control of and provision for children by parents, and in the obedience of children to parents, in the training of the young by the old, in the care for widowed relations, in the kindness of master to slave and faithfulness of slave to master, in a more willing service to Christian masters: it is to be exhibited in civic life, for the Christian is to pray for his rulers $\left(\mathrm{I} 2^{2}\right.$ ), to be obedient to authority (Tit $3^{1}$ ), to join in any good civic work, to be occupied in any trade that is respectable, and not to incur the charge of being a useless citizen ('Tit $3^{1.8 .14}$ notes). It is to be exhibited in Church life: for the character of the ministers is to be the model for all, and their life 
is to be under supervision and discipline, their work duly rewarded, their sins duly punished. The whole life is being disciplined, educated in righteousness, under the grace of God

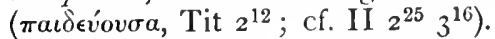

Two things may be noted about this type of character: $(a)$ it denotes a second stage in the Christian life; that life has passed through the excitement of conversion; there is none of the restlessness which St. Paul had to rebuke in the Corinthian Church; none of the upsettal of ordinary duties and family life which resulted from the expectation of a speedy coming of the Returning Lord ; there are only slight hints of the controversy between law and grace $\left(\mathrm{I}^{8}\right.$, Tit $\left.3^{5}\right)$ : the true purpose of law is seen in due proportion, and the "sound teaching" of the Christian Church is felt to incorporate, while it transcends, the commands of the decalogue ( $1^{8-11}$ notes). Another cause operated to effect the same result. The sense of the speedy Parousia of the Lord had passed away: we have no longer a "crisis-ethic"; the more abiding relation of the Church to this world is being defined. In a sense Christian Teachers are necessarily falling back on the Rabbinic effort to regulate exactly the duties of daily life, but the teaching is quite free from meticulous scrupulousness; the central religious motives are kept central. The ideal is the same as that described in Clement of Rome (c. I) and Justin, as that which Tertullian pointed to as realized in his time as marked by "gravitas honesta," and

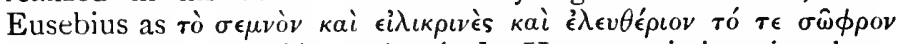

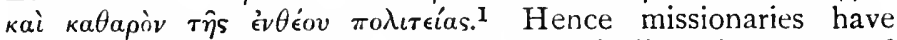
turned to these Epistles for guidance in dealing with a second generation of converted heathen. ${ }^{2}(b)$ While it stands in striking contrast to the past heathen life of the converts and to the general standard around them (Tit $3^{1-5}$ ), yet it shows how close the Christian character comes to the best ideal found in Greek and especially in Stoic Ethics. St. Paul had bidden the Philippians note well, wherever they might be found, all things

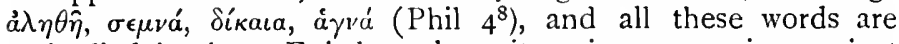
embodied in these Epistles : the writer gives a warning against falling short of a heathen standard ( $\mathrm{I}^{8}$ ): $\sigma \omega \phi \rho o \sigma v v \eta^{\prime}$ and '́ $\gamma \kappa \rho a \tau \epsilon i \alpha$ are as central in Plato and Epictetus as here : $\epsilon \dot{v} \sigma \epsilon \beta \epsilon \epsilon^{\prime} a$ (I $2^{2}$ note) and $\theta \epsilon o \sigma \epsilon \beta \epsilon i a\left({ }^{\prime} 2^{10}\right.$ ) are common terms in Greek religion: аитаркєía is a special note of Stoicism: many of the qualities required for Christian men and women are found already on Pagan Inscriptions; the illustrations quoted in the

${ }^{1}$ Clem. Rom. i. I ; Justin, Apol. i. Io; Tert. ae Preser. Har. c. 43. Eusebius, H.E. iv. 7, quoted by Bright, Some Aspects of I'rimilive Church life, pp. $140-52$, an excellent account of the early Christian ideal.

${ }^{2}$ Cf. Brown, The Pastoral Epistles, passim 
notes of Wetstein and Dibelius are illuminating in this respect; the qualities required for a ruler in the Church have many points of contact with those of the Stoic wise man or those of a Greek general ( $13^{2}$ note); the ideal of Marcus Aurelius is very similar: for him man acts as priest and servant of the gods (iii. 4), his conduct is serious and dignified ( $\sigma \epsilon \mu \nu o ́ s$, i. 9, ii. 5): with him goodness is beautiful (ii. I) : man-even an emperor-should be

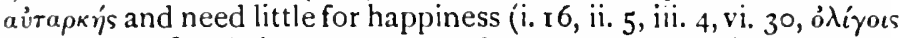

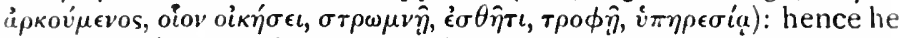
is $\dot{\epsilon} \gamma \kappa \rho a ́ r \eta s$ (i. I 5), sober-minded ( $\nu \hat{\eta} \phi o v \dot{\epsilon} v \pi \hat{a} \sigma \iota$, i. I6, iv, 26, vi. 31 ): sound in judgment (íyins, iv. 5 I , x. 35), of ordered beauty (кó $\sigma \mu \iota$ s, iii. 7); he is an athlete in the noblest contest (iii. 4); he has the same dislike for profitless speculations (i. 7). The lists of moral virtues found in him correspond very much with those of these

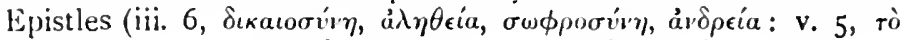

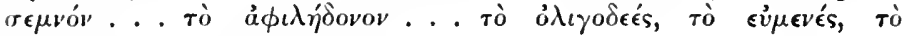

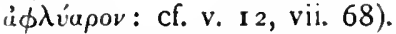

The writer wishes to say to his churches: You are settling down to join in the life of the Empire, to hold your own with your Pagan neighbours; therefore you must not fall short of their moral standard: your life must incorporate the highest virtues on which their teachers lay stress; nay more, it must aim at a standard of excellence which shall adorn the doctrine of your Saviour, because the Christian life is one of the chief means which will attract Pagans to Christ (I 61, 'Tit 25.8.10, and cf. I $\mathrm{P}_{2}{ }^{12} 3^{1.2}$ ).

"The true ecclesiastical life and the true Christian life and the true human life are all one and the same;" 1 but there lies behind the two former a motive in the relation to a personal Saviour from sin, which enabled Christianity to win its way to all classes of men to a degree which Stoic Ethics never touched. ${ }^{2}$

The Apostolic Teaching.-One means for securing this high level of character is loyalty to the Apostolic teaching. This in based upon "the words of the Lord Jesus Christ" (I $6^{3}, \mathrm{cf} .5^{18}$ ), on the Gospel of St. Paul ( $2_{2}{ }^{7}$, II ${ }_{1}^{13} 2^{8} 3^{10}$ ), on the inspired Scriptures of the O.T. ( $\mathrm{I}_{5}{ }^{18}$, II $3^{16}$ ). It is expressed in stereotyped phrases: it is $\dot{\eta} \delta, \delta a \sigma \kappa a \lambda i a\left(\right.$ I $\left.6^{1}\right): \dot{\eta} \kappa a \lambda \dot{\eta} \delta i \delta$. (I $4^{6}$ ):

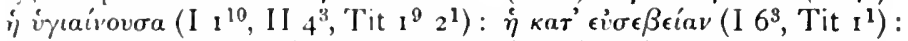

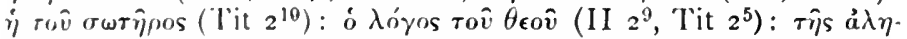

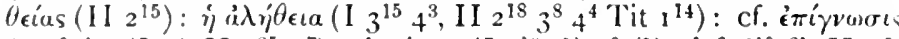
à $\lambda \eta \theta \operatorname{cius}\left(\right.$ I $2^{4}$, II $2^{25} 3^{7}$ ): $\dot{\eta} \pi i \sigma \tau \iota s$ (I $1^{191}$ (?) $3^{9}$ (?) $4^{1.6} 6^{10.21}$, II $3^{8}$,

'Ilort, The Christian Ecclesia, p. 200.

${ }^{2}$ For a full account of the trealment of the Greek cardinal virlues by I'hilo and by the carlicest Chri-tian teachers, cl. Strong, Christian Ethics, Nole on Leclures III. and IV. 


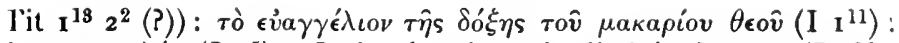
$\dot{\eta} \pi \alpha \rho \alpha \gamma \gamma \epsilon \lambda i a\left(\mathrm{I} \mathrm{I}^{5}\right)$. It is already embodied in hymns $\left(\mathrm{I}_{3}^{16}\right)$, in faithful sayings ( $\mathrm{I}^{15} 3^{1} 4^{9}$, II $2^{11}$, Tit $3^{8}$ ), and the germs of a creed seem to be implied in I $6^{13}$, II $4^{1}$.

In contrast to this there are false teachers and false teaching, but the allusions to their exact doctrines are not clear. They are teachers within the Church (cf. Acts $20^{30}$, Rev $2^{2}$, which both show the existence of false teachers at Ephesus), some of whom have already been handed over to Satan ( $\mathrm{I}^{19.20}$, II $2^{1 \tau}$, cf. Tit $3^{10}$ ); they lay great stress on the importance of their teaching (I I ${ }^{7}, \delta<\alpha \beta \varepsilon$ -

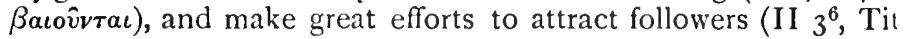
$\left.{ }^{11}\right)$. Some of them are Jews, others are not (Tit $\mathrm{I}^{10}$ ): there is no reason for supposing all the allusions to be to one set; there were many varieties of false teaching in Ephesus (Acts 19 $9^{\mathbf{1 - 4 . 9}}$.13 $^{3}$ and $20^{29.30}$, and there seem two distinct tendencies.

(i) Jezvish.-This is clearly marked in Titus ( $\mathbf{I}^{10}$ oi $\boldsymbol{\epsilon}^{\prime} \kappa \tau \hat{\eta} \mathrm{s}$

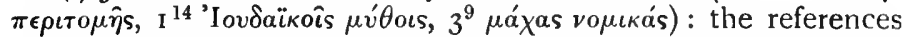
to "myths and genealogies" in $\mathrm{I} \mathrm{I}^{4-7}$ (where the teachers clain to be $\nu 0 \mu \sigma \delta \iota \delta \alpha \dot{\sigma} \kappa \alpha \lambda o \iota) 4^{7}$, II $4^{4}$ would most naturally be explained by the passages in Titus and probably do refer to Jewish Haggada, though they certainly are capable of adaptation to the Gnostic æons and genealogies and the Gnostic stress on knowledge as the method of salvation (vid. notes ad loc.). The falselycalled knowledge (I $6^{20}$ ) will in this case refer to Rabbinical pride in knowledge of the law.

(ii) Gnostic.-Springing out of a belief in the evil of matter : this is the probable reference of $I^{1-5}$, where the reference to the prohibition of marriage and ascription of the source of the teaching to "devils" make it almost impossible to trace that source to Judaism. With this may be classed the denial of the literal Resurrection (II $2^{17}$ ) and the possible allusion to magic (II $3^{8.13}$ ). These are forms which and century Gnosticism took (vid. notes ad loc.); but similar tendencies were in existence in the ist century (cf. I Co $15^{12}, \mathrm{Col}_{2}^{8}$, Ro ${ }_{14}, \mathrm{Heb}_{1} 3^{4}$ ).

Of our Epistles, $2 \mathrm{Ti}$ is the least determinate and gives little guidance as to the nature of the teaching: Titus is markedly anti-Jewish; I $\mathrm{Ti}$. has the most definite statements, yet they are ambiguous and are capable of reference either to Jewish or Gnostic teaching; if it was uritten after Titus and was intended as a general direction to all the Pauline churches, it may have intentionally widened the allusions in Titus, so as to make the warning applicable in different directions. But the main reason of this ambiguity is that the writer is not so much concerned with the doctrines as with the moral tendency of the rival teachings. On the one hand, the Apostolic teaching tends to produce excellence of character $\left(\kappa \kappa \lambda \eta^{\prime}\right):$ it is sound and healthy 


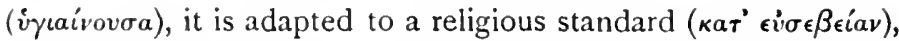
its one aim is "love out of a pure heart" $\left(\mathrm{I}_{1}{ }^{5}\right)$, the Lord has placed His own stamp upon it (II $2^{19}$ ). To remain loyal to it appeals to the deep instinct which regards the care of a deposit as a solemn trust (cf. note on $\pi a \rho a \theta \eta^{\prime} \kappa \eta$, II $\mathrm{I}^{12}$ ). On the other hand, the filse teaching is aimless $\left(\mathrm{I}_{1}{ }^{6}\right)$, empty of real substance (I $6^{20}$ ), useless (Tit $3^{9}$ ), ruinous to character (II $2^{14}$ ); it springs out of failure to keep a good conscience (I ${ }^{19}$ ), and leads to quibbling argumentation, to discord and ill-will $\left(\mathrm{I}_{\mathrm{I}^{4}} 6^{4}\right)$. The writer's feeling is closely akin to that of Socrates towards the Sophists, of St. Paul towards the Corinthians who placed knowledge before love ( $\mathrm{r} \mathrm{Co} \mathrm{8,} \mathrm{Col}$ 2), of Marcus Aurelius, who was grateful to Rusticus that he had first learnt from him the need of moral correction and amendment, and renounced sophistic ambitions (i. 7).

Church Organization and Ministry.-The Church addressed is one organized community, an ecclesia of a God of life,

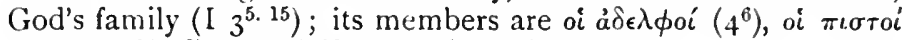
$\left(4^{12}\right.$, cf. $\left.5^{16} 6^{2}\right)$, å $\gamma \iota \iota \iota\left(5^{10}\right)$, oi $\dot{\eta} \mu \epsilon^{\prime} \tau \rho \circ \iota$ (Tit $3^{14}$ ).

There are meetings for worship both evening and morning

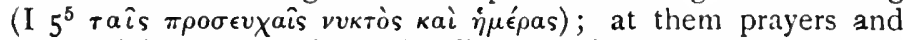
thanksgiving are combined $\left(\mathrm{I}^{1}\right)$; there is reading of Scripture, exhortation, teaching ( $\mathrm{I}_{4}{ }^{13}$ ); men and women worship together and the desire of women to teach is checked by the writer: it is not clear whether any man present might lead the prayers, or whether this was confined to a minister ( $\mathrm{I}^{8}$ note).

Baptism is the method of salvation and new burth (Tit $3^{5}$ ), and an allusion to a baptismal profession of faith in God and in Christ Jesus is probable in I $6^{12}$.

There are also meetings for discipline ('́vóm $5^{20}$ ), though it is not clear whether these would be meetings of the whole Church or only of the presbyters.

Ministry.-(a) The Apostle.-The Apostle, as receiving his commission from Jesus Christ, and as in the service of God (Tit $1^{1}$, I $1^{1}$, II ${ }^{1}$ ), has the supreme authority. He lays stress on his own Gospel $\left(\mathrm{I}_{\mathrm{I}^{11}} 2^{7}\right.$, II $1^{10-13} 3^{14}$, Tit $\left.\mathrm{I}^{3}\right)$, solemnly entrusts it to his delegates ( $\mathrm{I}_{\mathrm{I}^{18}}{ }^{18}$, hands over false teachers to Satan (I $\left.\mathrm{I}^{20}\right)$, and, though contemplating a speedy return, sends to his delegate exact instructions and wishes about his teaching, the details of common worship, the choice of and discipline over the ministers.

(b) The Prophets are referred to as having in the past pointed out 'Timothy to St. Paul for his work $\mathrm{I} \mathrm{I}^{18} 4^{14}$, but there is no reference to any present action by them. 
(c) The Afostle's delegates, Timothy and Titus. - No official title is given to them: Timothy is called an "Evangelist" (II $4^{5}$ ), a man of God (I $6^{11}$ ), the Lord's servant (II $2^{24}$ ); his task is one

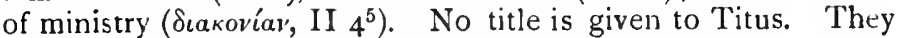
both have power given them to teach themselves, to hand on the Apostle's Gospel, to control the teaching of others (I ${ }^{3}$ II $2^{14}$ ); to ordain ministers, to exercise discipline over them "with all authority" (I $5^{17-25}$, II $4^{2}$, Tit $2^{15} 3^{10}$ ), both for reward and for punishment; to remit penalties once inflicted (?) $\left(I 5^{22}\right)$; to regulate the roll of widows $\left(\mathrm{I} 5^{9}\right)$. Each is to be a model of character as well as of teaching (I $4^{12}$, Tit $2^{7}$ ).

But it is not clear whether they received special consecration for this task. No allusion is made to this in the case of Titus: in the case of Timothy it is probably implied in $11^{18} 4^{14}$, II $1^{6}$ : he has had hands laid upon him by the Apostle and by presbyters at some time, but all these allusions may refer to some earlier event in his life. Nor is it clear what was their exact status. They may have been only temporary delegates $s \in \mathrm{nt}$ to deal with temporary emergencies, as they had been sent before to the Church at Corinth, and I Ti $1^{3} 3^{14.15} 4^{13}$, Tit $\mathrm{I}^{5} 3^{12}$ point this way (cf. II $4^{10}$ where Titus is sent to Dalmatia) : or they may have received some permanent commission and consecration to act as the Apostle's delegate at any place to which from time to time he might send them: and II $4^{12}$, Tit $3^{12}$ may imply that, when they were recalled, someone else was put in their places; or, lastly, it is possible that they had received permanent commission with permanent localization at Ephesus and Crete, their recall being only temporary. II $4^{5.6}$ seems to imply that Timothy would remain at his task after the Apostle's death, though not necessarily at Ephesus. I Timothy and Titus favour the first of these views, 2 Timothy the last, and a change may have been made in Timothy's position when Paul returned to Ephesus; but in any case they are "the instruments of an absent rather than the wielders of an inherent authority" (Moberly), and it is ordination at some point in their lives which gives them grace and power, to the fact of which the Apostle can appeal. They are Vicars Apostolic rather than monarchical bishops, but they form the transition to the monarchical Episcopate of the 2nd century.

(d) Local ministry.-There are grades in the ministry: the $\dot{\epsilon} \pi \iota \kappa \kappa \pi \dot{\eta}$ is already an object of desire: the deacon, if he serves well, may pass to a higher grade $\left(\mathrm{I}^{1.13}\right)$. But it is not clear whether there are two or three grades. Three titles are

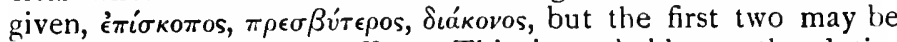
different titles for one office. This is probable, as the duties assigned to each, and the requisite character of each, are almost identical; cf. $13^{2-7}$ with Tit $1^{6-9}$; and this is confirmed by the 
absence of any reference $10 \pi \rho \epsilon \sigma \beta v i \tau \epsilon \rho \circ$ in $\mathrm{I} 3^{2.13}$, and tc

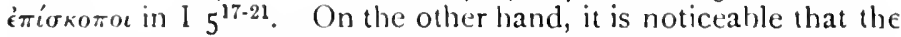
bisholl is always referred to in the singular with the definite article prefixed (

The Bishop's relation to the Church is like that of a father to a family: his duty is $\pi \rho \operatorname{ti}_{\sigma \tau} \alpha \sigma \theta a \iota, \epsilon^{\prime} \pi \iota \mu \epsilon \lambda \epsilon i \sigma \theta u \iota, 13^{4.5}$, to preside at meerings, to keep discipline, to take forethought for the whole, to teach $(\delta \iota \delta \alpha \kappa \tau \iota \kappa o ́ v), ~ t o ~ e x h o r t$, to rebuke (T'it $\left.{ }^{9}\right)$ : he represen's the Church to the outside world $\left(\mathrm{I}_{3}{ }^{7}\right)$, and has to welcome Chris-

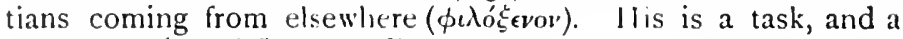

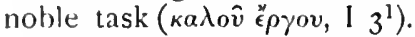

The Presbyters are a group of elders in each city (Tit $\mathbf{1}^{5}$, $2 \mathrm{Ti} 2^{2}$, cf. $\left.\tau \hat{o} \pi \rho \epsilon \sigma \beta v \tau \epsilon^{\prime} \rho v^{\prime}, \mathrm{I}^{14}\right)$ : they are formally appointed (Tit $\mathrm{I}^{5}, \mathrm{I} \mathrm{Ti}^{22}\left(\right.$ ?) ) and tested before appointment ( $\mathrm{Ti} 3^{10} \kappa \alpha i$ ovirou): their duty is to "preside" and to teach ( $1 \mathrm{Ti}^{17}$ ): they receive some honorarium, which is increased if their work is well done: they are liable to censure and formal judgment before the whole body (ib. ${ }^{19-22}$ ). They also take their part in laying hands

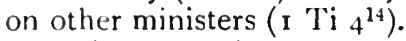

It is then quite possible that these are two different titles for one status; and if so, "presbyters" would be the title, springing out of the analogy of the Jewish synagngue, a small group of leading men chosen by the founder of each church to manage its affairs after he had gone: and "bishops" would be a description of their function as taking oversight. This is strongly supported by Acts $20^{17}$ and ${ }^{28}$; cf. Phil $\mathbf{r}^{1}$. But it would be frequently necessary for the church to be represented by some one officer, whether to manage the finances and exercise hospuitalıty to strangers, or to preside at a meeting for exercising discipline, or more frequently s!ill for presiding at the Eucharist (cf. o mpoєorós, Justin M. Apol. i. 67), and the title "the overseer" would naturally be applied to the preshyter so acting, without implying any difference of grade or permanent status. This would explain the constant use of the singular.

Deacons.-The existence of the office at Ephesus is assumed, and their duties are not defined. Stress is laid upon their character, both as fitting them for their own work of assisting in church service and administration of charity, and as preparing them for the higher office of the presbyterate to which they may aspire. Their character, perhaps also their soundness in the faith, has to be formally tested before they can enter upon their office. They are not mentioned at all in the churches of Crote.

(e) Mfinistry of zeomen.-(i) The ministry of deaconosses is almost certainly referred to in I Ti $3^{\prime \prime}$, but no definition of their duties or of the method of their appointment is given.

(ii) Widmers.- There is already in existence an order of 
Church IVidows whose names are kept on a regular list. The writer's aim is to limit this list. It is possible that those on the list were used for deeds of kindness to others, but this is not clearly stated. The main purpose of the order was eleemosynary. No one is to be placed on it who is under sixty years of age, or who can be supported by her own relations: only excellence of character qualifies for admission.

For fuller details cf. the notes on each passage. The following books should be consulted: Bp. Lightfoot, The Christian Ministry; Hort, The Christian Ecclesia, cc. xi. xii.; Hatch, The Bampton Lectures, 1880; Lindsay, The Church and the Ministry in the Early Centuries, r903; Lowrie, The Church and its Organisation (based on Sohm's Kirchenrecht), r 904 ; Harnack, Constitution and Lave of the Church, Eng. Ir., I9Io; Swete, The Early History of the Church and Ministry, Essay II., I918; Gore, The Church and the Ministry, c. v., I9I9; Headlam, The Bampton Lectures, c. ii., 1920.

For the previous use of the words $\epsilon \pi i \sigma \kappa o \pi o s$ and $\pi \rho \epsilon \sigma \beta \dot{\tau} \tau \epsilon \rho \circ$ in connexion with religious officials, cf. Deissmann, B.S. s.vv., M.M. s.vv.; Gore, ubi sup., ed.2, Note K.

Theology.-(i) The conception of God is mainly that of the O.T., with the sense of His Fatherhood deepened by the revelation of Christ, and with more abstract qualities emphasized, perhaps through the influence of Greek philosophy upon Jewish thought. ln essence $\mathrm{He}$ is One only $\left(\mathrm{I} 2^{5} 6^{15}\right)$ : a God of life $\left(\mathrm{I} 3^{35} 4^{10}\right)$ : the Happy God (I $\left.\mathbf{r}^{11}\right)$ : immortal, invisible (I $\left.6^{15}{ }^{16}\right)$. In manifestation $\mathrm{He}$ is creator of all things $\left(\mathrm{I}_{4}^{4}\right)$, holding them in life (I $6^{13}$ ), giving them bountifully for man's enjoyment (I $\left.6^{17}\right)$. $\mathrm{He}$ is father of men, willing all to be saved ( $\left.\mathrm{I}^{4}\right)$ : true to $\mathrm{His}$ promises (Tit $\mathrm{I}^{2}$ ): the King of all the ages $\left(\mathrm{I}^{17} 6^{16}\right)$ : revealing

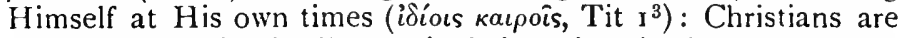
His elect (II $2^{10}$, Tit $\mathrm{I}^{1}$ ): He is their saviour in the fullest sense $\left(\mathrm{I} 4^{10}\right)$ : the Church is His family $\left(\mathrm{I} 3^{5.15}\right.$, II $\left.2^{15.19}\right)$ : its ministers are His slaves (II $2^{24}$ ), His stewards ("Tit $\mathbf{r}^{7}, \mathrm{I} \mathrm{I}^{4}$ ), His "men "

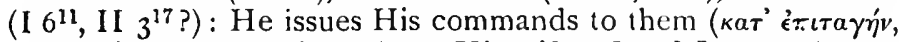
I $1^{1}$, Tit $1^{3}$ ): He gives them $\mathrm{His}$ gifts (II $1^{0.7}$ ): He is the source of grace, mercy, and peace $\left(\mathrm{I}_{\mathrm{I}^{2}}{ }^{2}, \mathrm{II}_{\mathrm{I}^{2}}\right.$, Tit $\left.\mathrm{I}^{4}\right)$ : the giver of repentance to those who have gone astray (II $2^{25}$ ): the object of hope $\left(\mathrm{I} 5^{5}\right)$ : the future Judge (cf. I $5^{21}$ ).

(ii) The conception of Christ is primarily that of the Jewish Messiah-X never 'I $\eta$ roûs alone or Xpırós alone (cf. Harrison, p. 57)-but the Messiah as one with Crod in His universal love and work; perhaps also modified by an intentional contrast with the deified 
Roman Emperor (Tit $2^{13}$ note). He is thought of as existing betore all time (II $1^{9}$ ): His earthly life was a manifestation $\left(\mathrm{I} 3^{16}\right)$, a coming into the world $\left(\mathrm{I}^{15}\right)$; yet $\mathrm{He}$ was truly man, able to represent all mankind before $\operatorname{God}\left(\mathrm{I}_{2}{ }^{5}\right)$. His teaching is perhaps referred to $\left(\mathrm{I}^{3}\right)$ : His true confession before Pontius Pilate $\left(\mathrm{I} 6^{13}\right)$ : His self-sacrifice $\left(\mathrm{I}^{\mathbf{2}^{6}}\right)$ : His atoning death (Tit $\mathbf{2}^{14}$ ). But He is mainly thought of as the Risen Lord; the mediator between God and man ( $\left.2^{5}\right)$; the saviour, the source with the Father of grace, mercy, and peace: the giver of wisdom (II $2^{7}$ ): the source of life itself $\left(\right.$ II $\left._{1}{ }^{1} \cdot{ }^{10}\right)$ : the inspirer of courage (II $\left.\mathbf{2}^{8}\right)$ : the object of our faith $\left(\mathrm{I}_{1}{ }^{16}\right)$ and of our hope $\left(\mathrm{I}^{1}\right)$ : for whose final appearing Christians long (II $4^{8}$ ), because He guards safely our deposit (II I ${ }^{12}$ ), and with the Father will be the righteous Judge, giving the crown of righteousness to the righteous and rewarding the wicked according to their deeds (II ${ }^{18} 4^{8.14}$ ). $\mathrm{He}$ is called "the glory of our great God and Saviour," or perhaps "our great God and Saviour" (Tit $2^{13}$ note).

(iii) To the Holy Spirit there is little allusion; He may be referred to in I $3^{16}$ as the inspirer of Christ's perfect life. He is the source of the inspiration of Christian prophets $\left(\mathrm{I}^{1}\right)$ : to all Christians $\mathrm{He}$ is the source of the renewal given in Baptism (Tit $3^{5}$ ), and the indwelling power which enables them to be loyal to their trust (II $\mathbf{1}^{14}$ ).

Date.-On the assumption of the Pauline authorship the date must be subsequent to St. Paul's imprisonment at Rome and before his death, and will fall between A.D. 60 and 64 . But deferring this problem, the evidence is very uncertain. Any date between 60 and $I_{1} 5$ is possible; between 60 and 90 probable.

External evidence.- The surest starting-point is the rejection of their Pauline authorship by Marcion. This implies their existence and their attribution to St. Paul by others before A.D. I 40. About the same date they were included in Syriac and Latin versions. Further, there are striking coincidences with their language to be found in the Epistles of Ignatius and Polycarp, which make it probable that they were well known before A.D. I 15. There are again possible reminiscences of their language and a real sympathy of tone between them and the Epistle of Clement, A.D. 95. (For reference, cf. von Soden, Hdc.,p. 15 I ; The Neal Testament in the Apostolic Fathers, p. 137 ; Harrison, pp. I77, 178 ; Von der (ioltz, T. und U. xir. iii., pp. 107-18, 186-94.)

Internal evidence. - (a) Church organization. - A regular ministry of at least two grades is already in existence: the presbyters are salaried: they are liable to discipline: they form a higher grade to which deacons may be advanced: the position of $\dot{\epsilon} \pi \dot{\sigma} \sigma \kappa \pi \%$ is already an object of desire; only those who are 
not newly-converted may be appointed to office. There are many widows, some of more than sixty years of age; some have already been untrue to their profession. This implies a Church of some years' standing, but is possibly consistent with a period of twelve years, which may have elapsed between the first foundation of the Ephesian Church by St. Paul and his imprisonment at Rome. On the other hand, the uncertainty of the exact position held by Timothy and Titus, and the uncertainty of the

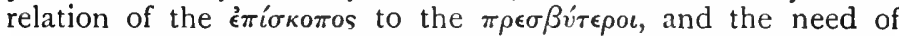
regulating the worship of men and women, are quite different from the situation implied in the letters of Ignatius, and point to a date not later than the ist century. The need of the enforcement of prayer for the Empire points to a time before Clement's letter.

(b) Relation to the outside world.-The chief danger of false teaching comes from Judaism ; there are also traces of Gnosticism, but in an incipient form, not nearly so developed as in Marcion. The Church is settling down to play an active part in the world : it prays for the Empire; its members are encouraged to loyalty and active service as citizens ; the characteristic of Christian life embodies all the virtues of Stoicism: "The writer is a type of the time when the ethical voice of a noble Hellenism and the Roman instinct for organization are uniting themselves with the Christianity which had sprung as religion out of Judaism" (von Soden): the notes of the Christian character already found in the Corinthian Church in the time of Clement of Rome (c. I) recall those of these Epistles. Some of the best illustrations of the writer's meaning are to be found in Ignatius or Tertullian or Cyprian (cf. notes on $\mathrm{I}_{2}{ }^{15} 5^{22}$, Tit $3^{8}$ ): but there is no indication that those imply customs which had arisen in the and century. Tertullian often adds cautions to guard against dangers which might arise from the language of the Epistles; cf. Tert. de Idol. c. 8: "cavere debemus ne quid scientibus nobis ab aliquibus de manibus nostris in rem idolorum postuletur." Ib. I2 : "ut non usque ad idololatriæ affinitates necessitatibus largiamur." Ib. I 5 : "subditos magistratibus ... sed intra limites disciplinæ, quousque ab idololatria separamur." In the same way a comparison of the advice to slaves in I $6^{\mathbf{1 . 2}}$ as compared with that in Ignatius and Polycarp points to an earlier date.

(c) Literary dependence.-(a) The Gospels.-There is no reference to the existence of written Gospels: in I $5^{18}$ a saying recorded in St. Luke's Gospel is quoted; possibly as Scripture, though probably not (vid. note): I $6^{3}$ possibly implies a collection of the Lord's discourses, and Q may have been known to the writer; but the coincidences with the Gospel sayings are quite explicable as due to oral tradition. The more striking are: 


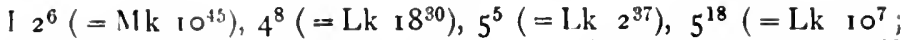
I.h agrees verbally, Mt differs $), 6^{17-19}\left(=\mathrm{Lk} \mathbf{1}^{20.21}\right)$, II $2^{19}$ $\left(=\mathrm{MI} 7^{23}\right)$, II $4^{18}\left(=\mathrm{Mt} 6^{13}\right)$, Tit $\mathrm{I}^{15}\left(=\mathrm{Mk} 7^{19}\right.$, Lk $\left.{ }_{1}{ }^{41}\right), 3^{5}$

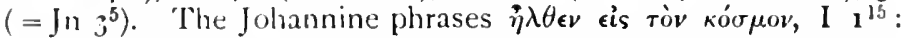
$\dot{\epsilon} \phi a v^{\epsilon} \rho \dot{\omega} \theta \eta \dot{\epsilon} \dot{\epsilon}^{\prime} \sigma \alpha \rho \kappa i, \mathrm{I} 3^{16}$, are found in quotations Irom "faithful sayings" or "hymns."

(b) The Epistles.- There are many coincidences of thought and language with St. Paul's Epistles, especially with Ro., I Co., Eph., Phil. Nearly all the reminiscences of the O.T. are of passages quoted by St. Paul: I $2^{13}$, cf. I Co I I $^{8}$ : I $2^{14}$, cf. $2 \operatorname{Co~}_{11}{ }^{3}:$ I $5^{19}$, cf. 2 Co $13^{1}$ : I $6^{1}$, cf. Ro $2^{24}$ : II $2^{20}$, cf. Ro $9^{21}$ :

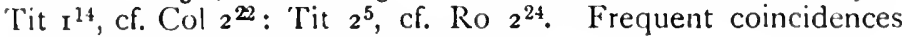
occur with St. Paul's own language:

with Ro.: I $1^{1.17}=\operatorname{Ro} 6^{26}: 1^{5}=\operatorname{Ro} I 3^{10}: 1^{8}=$ Ro $7^{16}: 2^{5}=$ Ro $3^{30}: 2^{7}=\operatorname{Ro} 9^{1}$.

II $1^{3}=\operatorname{Ros}^{8}: I^{7}=\operatorname{Ro} 8^{15}: I^{8}=\operatorname{Ros}^{16}: I^{9}=\operatorname{Ros} 6^{26}:$ ${ }^{14}=\operatorname{Ro} 8^{11}: 2^{11-13}=\operatorname{Ro} 6^{8} 8^{17}$.

Tit $1^{1-4}=\operatorname{Ro}_{1} 6^{26}: 1^{15}=\operatorname{Ro} 14^{20}: 3^{1}=$ Ro $13^{1}$.

with I Co. : $11^{12.13}=1$ Co $7^{25} 15^{10}: 2^{11.12}=1$ Co $14^{34}: 4^{4}=$ I Co $10^{30}: 5^{13}=1 \operatorname{Co}^{9}: 5^{17}=1$ Co $9^{14}$.

II $2^{4-6}=1$ Co $9^{7}:$ 'Tit $3^{3}=$ I Co $6^{9-11}$.

with 2 Co. : I $1^{11}=2$ Co $4^{4}$,

with Eph.: II $1^{8}=$ Eph $4^{1}$ : II $1^{9}=$ Eph $1^{4} 2^{8}$ : Tit $3^{3}=$ Eph $2^{3}$ : Tit $3^{5}=\mathrm{Eph} 2^{8} 5^{26}$.

with Phil.: II $4^{6}=\mathrm{Phil} \mathrm{I}^{23} 2^{17}$.

Of these, one or two passages $\left(\mathbf{I ~}^{2}\right.$, II $4^{6}$, Tit $\left.\mathbf{1}^{2.3} 3^{5}\right)$ suggest the possibulity of conscious literary imitation; but they, like the rest, are consistent with a general acquaintance with the Pauline language. They certainly imply a date when these Epistles were well known, and in $112^{11-19}$ we have a faithful saying formed out of Pauline phrases. For a fuller list of coincidences, cf. Harrison, l'p. I67-1 75; but many are included by him which are probably accidental.

The relation to $\mathbf{I}$ Peter is less clear. I $\mathrm{Ti}$ and $\mathrm{Tit}$ both deal like I $\mathrm{P}$ with the duties of family life and of obedience to government; I, like I P, deals with the dress of women with some linguistic sinilarity, but not sufficient to suggest dependence. Tit has also many points in common with I P: "the peculiar people" (Tit $2^{14}, \mathrm{P}_{2}{ }^{9}$ ): salvation by baptism (Tit $3^{5}$, ( $\left.\mathrm{P}_{1}{ }^{3} 3^{21}\right)$ : the stress on hope, on redemption from lawlessness (Tit $2^{14}, \mathrm{I}_{\mathrm{P}} \mathrm{I}^{18}$ ). Cr. Dr. Big , I.C.C., p. $2 \mathrm{I}$, who believes in a conscious connexion between T'it and I P ; von Soden, Handc., p. 174 , who thinks this also true of $\mathbf{~ ' ~} \mathrm{Ti}$; and Harrison, pp. I 75-6. But it is doubful whether there is more than the use of current Christian language; there may be a common dependence of each on some earlier Christian mannal of duties; and as between the 
two, there is no clear mark of priority. The only certain indica tion of date from literary dependence is that the Epistles are lates than the second and third groups of Pauline letters.

Authorship.-In face of the many points of connexion will the Pauline Epistles, the alternative theories of the authorship resolve themselves into two.

(a) They were written by St. Paul, after the other letters, all late in his life, $2 \mathrm{~T} i$ in the face of death. "These are my last instructions to my most trusted sons." This theory is consistent with the possibility of later additions to the original letter.

(b) They were written at the end of the Ist or beginning of the 2nd century by some Pauline Christian anxious to guard against false tendencies of teaching and a low standard of life; for this purpose writing in Paul's name in order to strengthen his own authority, and perhaps incorporating genuine fragments of Paul's letters. This would scarcely have been regarded as a forgery, but only as equivalent to saying, "This is what Paul would say to you, if he were now alive."

The farewell address of St. Paul to the elders of Ephesus Ac $20^{17-38}$, has many points of contact with the Past. Epp. They would be a natural sequel to it by St. Paul himself, or it might have been taken by an imitator as a model on which the Epistles were framed: cf. the appeal to his own past sufferings (Ac $20^{19.23}$, $\left.2 \mathrm{Ti} 3^{11} 4^{7}\right)$; his anticipation of future false teachers and apostasy $\left(20^{29}, \mathrm{I} \mathrm{Ti} 4^{1}, 2 \mathrm{Ti}^{1}\right)$; his eagerness to fulfil his course

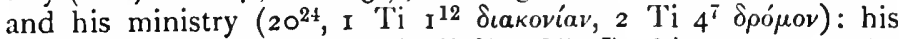
sense of his independence $\left(2 \mathrm{O}^{33.34}\right.$, I Ti $\left.6^{7}\right)$ : his stress on " the church of God," "the peculiar people" $\left(20^{28}\right.$, I Ti $3{ }^{15}$, Tit $\left.2^{14}\right)$ : the interchange of $\pi \rho \epsilon \sigma \beta \dot{\tau} \tau \epsilon \rho \circ$ and $\dot{\epsilon} \pi \boldsymbol{i} \sigma \kappa o \pi \circ:$ his deposit with $\operatorname{God}\left(20^{32}, 2 \mathrm{Ti}_{1}{ }^{12}\right)$ : his stress on the true use of money $\left(20^{35}\right.$, 1 Ti 69.10.17-19).

Either they are genuine "letters" or artificial "Epistles" (like the Ars Poetica of Horace): the nearest analogy to their form is the letter of Ignatius to Polycarp, which strongly favours the first alternative.

External evidence. - The evidence of Church writers is the same as for the other letters of St. Paul. They are all quoted as St. Paul's by Irenæus (c. Har. Praf. ii. 14. 7, iv. 16. 3 (1 Timothy)): iii. 2. 3 , iii. 14. I (2 Timothy); i. 16. 3 ('Titus)). They were incorporated, with St. Paul's name embodied in them, in Latin and Syriac Versions of the and century: their existence is almost certainly implied by coincidences with their language in Barnabas, Ignatius, Polycarp (cf. N.T. in Apostolic Fathers, pp. I 2-I 4, 71-73, 95-98), and probably in Clement (cf. Harrison, p. I77), so that it is probably carried back to a Ist 
century date, when a mistake about their authorship is unlikely No other author's name has ever been suggested.

On the other hand, there were doubts from early in the and century. The Pauline authorship of all was denied by Basilides and Marcion (Tert. aav. Marc. v. $2 \mathrm{I}$ ); that of $\mathrm{I}$ and 2 Timothy by Tatian, who accepted Titus (Jerome, Prol. ad

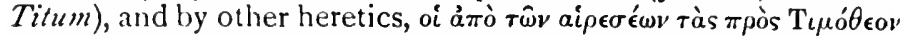

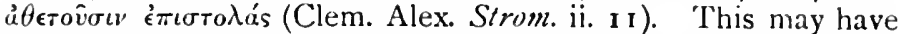
been due, as Tertullian, Clement, and Jerome assert, to dislike of their teaching; or to some special source of knowledge, such as Marcion seems to have had about the destination of the Epistle to the Ephesians. Dislike of the doctrine would naturally have led Marcion to treat them as he did the otler Epistles, erasing sections rather than repudiating the whole.

Internal evidence.-The Pauline authorship is not only stated in the Salutation of each letter, but in $\mathbf{I}$ and 2 Timothy is implied in constant personal references either to St. Paul's own life (I ${ }_{1}^{11 .}$ 12-16 $_{2} 2^{7}$, II $1^{3}$. $11.12 .15-183^{10} 4^{6-8.9-18}$ ) or to his relations with Timothy (I $\mathrm{I}^{3.18} 3^{14} 4^{6-16} 5^{23} 6^{12.20}$, II $\mathrm{I}^{5.13 .18} 2^{1} 3^{10.11 .14}$ ). These references spring out of the situation; they are natural to an old man entrusting an inportant task to a younger; they correspond with the traits of St. Paul's character as seen in the earlier letters. There is the same practical wisdom, the same sense of the dependence of character on doctrine, the same self. consciousness recalling his own unworthiness, asserting his own commission, bursting out into doxologies, dependent on the affection of others, trusting them with great tasks, very sensitive to any failure in loyalty to himself, very confident of Christ's protecting grace, with loving eyes fixed on His appearing. The references are equally true to the character of 'Timothy as known elsewhere; he is young, not strong in health, timid, needing selfdiscipline, needing also encouragement and reminder of all that has prepared him for his task, of all his past training and loyalty, yet withal a "genuine" and "loved" son whom he can trust.

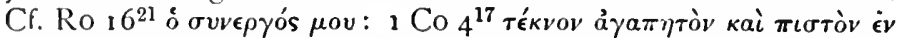

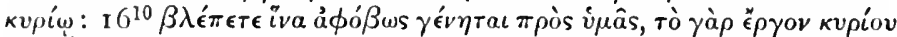

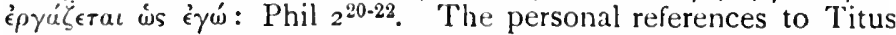
are much slighter, $\mathrm{I}^{5} 3^{12.13}$ : a comparison of $2^{15} \mu \eta \delta \epsilon^{\prime}{ }^{\prime} s$ on

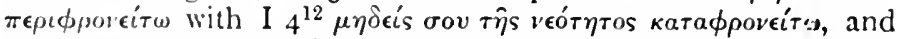
the absence of ${ }^{\prime} \lambda \epsilon$ s in the salutation, perhaps imply an older and stronger man ; and this corresponds with the impression convejed in 1 and 2 Co. (For a careful examination of these personal references, cf. Parry, c. 2.)

The doctrinal background is essentially Pauline. The "gooriness" of all creation ( $4^{4}$, 'Tit ${ }^{15}$ ), the universalism of salvation (I $2^{1-7}$ ), the Iivine initiative in it (II $1^{9}$, Tit $3^{5}$ ), the 
Divine overruling of the world and its history ( $\mathbf{I}^{17} 6^{15}$, Tit $1^{8}$ ): the conception of Christ's nature and work as the Risen Lord ( $\mathrm{I} 3^{16}$ II $2^{8}$ ), the thought of the Church as a family ( $\mathrm{I} 3^{1-15}$ $\left.5^{1}\right)$ and as the inheritor of the promises made to the Jewish nation (Tit $2^{14}$ ), are no longer discussed, but are all implied as the basis of Christian life. There is the same stress as in Col. and Eph. on the importance of a regulated family life: in one respect, indeed, there is a difference; here younger widows are advised to remarry, in I Co $7^{39.40}$ all widows were advised to remain unmarried, but that passage recognized the widow's freedom, and that advice was given under the expectation of a speedy Parousia of Christ. As we have seen (p. xv), there has been an advance, a change towards a more regulated life, a closer intercourse with the heathen world; but this would be quite natural in one who was a Roman citizen and brought up in Tarsus, a centre of Stoic Teaching.

Equally Pauline is the stress upon organization and discipline. He had impressed this upon his churches from the first (I Th $5^{12-15}$, 2 Th $\left.3^{6-14}\right)$ : he had called upon the Corinthian Church to join in the severe exercise of discipline ( 1 Co $5^{3.5}$ ): in his estimate of spiritual gifts he had ranked those that were organized, regular, that made for edification and for peace, above the more showy and emotional ( 1 Co $12^{28} 1_{4}^{1-33}$ ): the mininters were regarded as gifts of the Ascended Lord to the Church (Eph $\left.4^{11}\right)$. He is the Apostle of Subordination no less than the Apostle of Christian fieedom : ${ }^{1}$ these Epistles are (as Sir Wm. Ramsay has said) only an expansion of the message sent to Archippus, "Take heed to the ministry which thou hast received in the Lord, that thou fulfil it" $\left(\mathrm{Col} 4^{17}\right)$ : and such stress would naturally increase with the prospect of his own death (cf. $M k 3^{6.14}$ ). The details of the organized ministry correspond with those of Ro $16^{1}$ (deaconess):

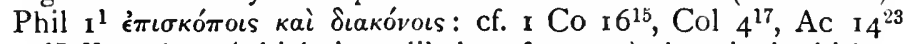
${ }^{2}{ }^{17.28}$, unless (which is unlikely, cf. p. $\mathrm{xx}$ ) the single bishop constitutes a separate grade. The position of widows is more defined than in $\mathbf{x}$ Co 7 ; but it is apparently being regulated in a very early stage, and Ac $6^{1} 9^{39}$ bear witness to the eleemosynary care for widows, and to their charitable activities, in the earliest days of the Church.

The style raises a more difficult problem. There are slight differences between II and I and Tit., II being more intricate in structure and often less clear in expression; but this is not more than is due to a difference of mood, and is very parallel to the difference between 1 and 2 Th. The style of the three may therefore be treated together, and clearly it is more like

${ }^{1} \epsilon \lambda \epsilon v \theta \epsilon p^{\prime a}$ and its cognates occur twenty-eight times in the earlier Epistles, inoтar $\eta^{\prime}$ and its cognates lwenty-1wo. 
that of St. Paul than that of any other N.T. writer, if it is compared, as it ought to be compared, not with either the argumentative parts of previous letters (e.g. Ro 1-9, Gal.) or the parts written under strong personal provocation ( 2 Co $\mathrm{I}-7$, 10-13), but with the more quiet and practical sections (e.g. Ro $10-15,2$ Co 8. 9). There is the same basing of practice upon doctrine, the same personal touches with references to his own past life, the same sense of his own responsibility, a similar fondness for adapting O.T. language, a similar use of Rabbinical Haggada and of quotations from classical writers (I $4^{4}$, Tit ${ }_{1}^{12}$ ), the same love of oxymoron ( $\zeta \hat{\omega} \sigma a \tau \epsilon^{\prime} \theta \nu \eta \kappa \epsilon \nu,{ }^{1} 5^{6}$ :

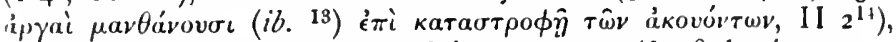

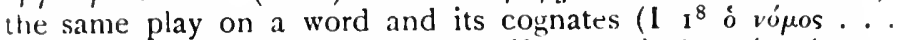

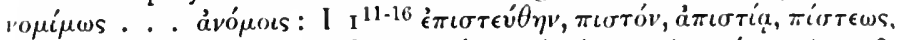

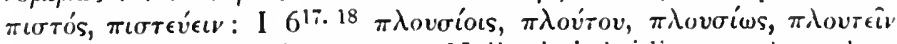

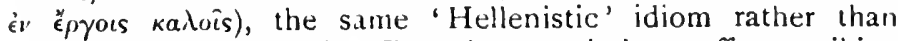
that of literary Greek. But the vocabulary offers striking differences. About $85^{\circ}$ words are used: of these over 170 are not used in N.T. writers, over 300 (including these I 70 ) not in the earlier letters, only about 50 are common to St. Paul and the writer alone; again, where 1 and 2 Th. show 8 in $\pi a \xi \lambda \epsilon \gamma^{\prime} \mu \epsilon v a$ to a page, Gal. Ro. 1 and 2 Co. from II to I 2 , Phil. 13, these Epistles show from 19 to 21. St. Paul shows, indeed, always a great choice of vocabulary and fondness for different groups of words at different times: thus of the words that he uses (about 2500), i 257 occur only in some one Epistle ; and whereas the proportion of $\alpha \pi a \xi \lambda \epsilon \gamma{ }^{\prime} \mu \epsilon v a$ is $\mathbf{I}$ for $\mathbf{I} 55$ verses in these Epistles, in 2 Co. it is 1 for every 3.66 , 11 I Co. I for $5.53^{2}$ Much is due to a difference of subjects treated, and a somewhat similar but scarcely an equal variety has been shown to exist in Shakespeare (Expository Times, June 1896, p. 418) and in the different parts of Dante's Divina Commedia (Butler's Paradise, p. xc). But the difference extends beyond mere words, it includes many stereotyped and

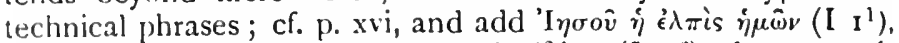

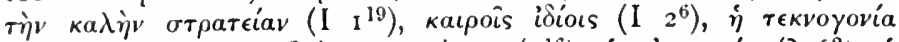

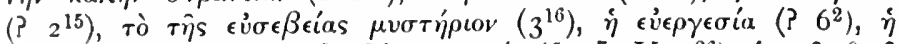

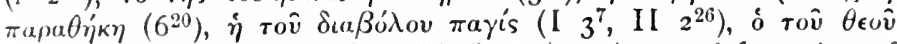

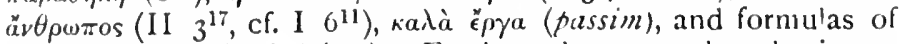

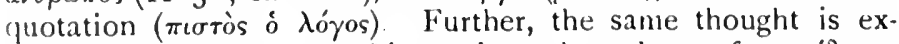

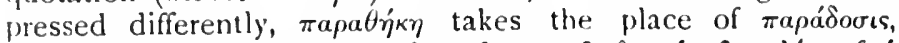

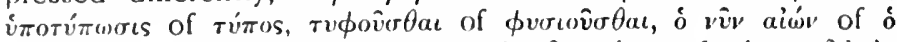

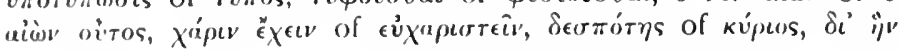

' Ceher die Sprache in den Pastoralbriefen, von Dr. F. Torm, Zisch. NT Wissenschaft, 1918, p. 229 sqq.

${ }^{2}$ Kö̈lling, ap. N'eiss, p. 51. 


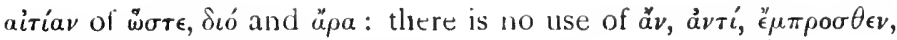

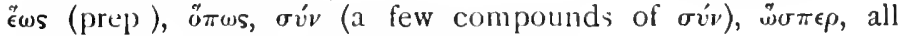
of which are fairly common in St. Paul.

This linguistic argument against the Pauline authorship has lieen greatly strengthened by the proof that the vocabulary shows a much greater approximation to the vocabulary of Christian and other writers of the 2 nd century than to that of the earlier letters. Thus of $175 \ddot{a} \pi \alpha \xi \lambda \epsilon \gamma^{\prime} \mu \epsilon v^{\prime} \alpha$ in these Epp., 6r occur in the Apostolic Fathers, 6I in the Apologists, 32 of which are not in the Apostolic Fathers, making $93 \mathrm{in}$ all (Harrison, pp. $68 \mathrm{ff}, \mathrm{I} 50, \mathrm{I} 5 \mathrm{x}$ ); and 82 words which are not lound either in the N.T. or in these Christian writers are found in Pagan writers of the and century (ib. p. 16r). This though very striking is not quite convincing, as these Epistles may have influenced the Christian writers, and as there is no evidence that the words are not earlic r than the and century.

The conciuiun is difficult. There is no word impossible to St. Paul, no word not natural to him. 'lhere are indeed three wurds which soon acquired a technical ecclesiastical meaning,

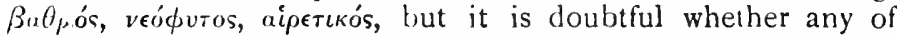
these has that meaning here; they are on the way to it, but have scarcely arrived. Much change of vocabulary, including even particles, is due to the kind of letter, not argumentative or impassioned but full of practical warning and guidance, not written to churches or to private friends but to close intimate fellow-workers (this would explain the use of stereotyped phrases); much may be due to lapse of a few years tending to introduce fixity of phrase and formula; something, perhaps, to the freedom used by the amanuensis, - it is a natural suggestion from II $4^{10}$ (if that is a part of the whole letter) that St. Luke was the amanuensis of $2 \mathrm{Ti}$, and there is a considerable quantity of Lucan non-Pauline words in all these Epistles (cf. Holtzmann,

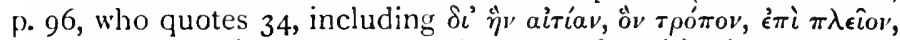

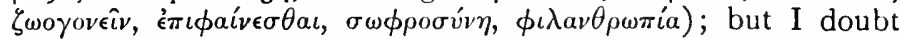
whether St. Paul would have allowed much freedom to an amanuensis. Some of the ${ }_{a}^{z} \pi a \xi \lambda \epsilon \gamma \delta \mu \epsilon \nu a$ are also semi-quotations from faithful sayings, from liturgical doxologies and hymns, very possibly from existing manuals on the qualifications for various offices: The argument from style is in favour of the Pauline auth'rship, that from vocabulary strongly, though not quite conclusively, against it.

[For th: arguments against, cf. Holtzmann, P.B. i. $\S 7$; Nägreli, der Wortschatz des Apostels Paulus, pp. 85-88, Göttingen, 1005 ; Miffatt, Introd. to N.T., I 9 I I ; Harrison, The Problem of the Pastoral Epistles, 1922 (far the most thorough, making previous discussions out of date) : for the arguments for, cf. (.. (i. 
Findlay in Sabatier, The Apostle Paul, I891; James, The Genuineness and Authorship of the Pauline Epistles, Igo6; P. Torm, "Ueber die Sprache in den Pastoral-Briefen," Zischr. fïr NT Wissensihaft, 1918, p. 225.]

The vocabulary in all the letters, and the impression, especially in $\mathrm{r} \mathrm{Ti}$, of a comparatively late stage in Church life, favour a late date; on the other hand, the lapse of years since the earlier letters and since the foundation of the Church at Ephesus, combined with the quickness of development which marks the early growth of a religious community, especially when face to face with other organized religious communities, as the Christian Church was face to face with the Jewish synagogue and the Pagan mysteries, make it possible to place these letters within St. Paul's lifetime, at any rate on the assumption that he was released from the first Roman imprisonment $;^{1}$ and the personal notes embodied in the substance of the letters, the doctrinal assumptions, the stress on character and ordered life, the incorporation of the best elements of Stoic morality, are all in favour of St. Paul. In this Commentary the whole of the Epistles are treated as coming direct from St. Paul's hand; that is what their author intended, whoever he was. But the strength of the case against them, especially as presented by Mr. Harrison, is doubtless very great, and every student should carefully examine his reconstruction of them as represented in his Appendix IV. He will see at once the extent of the nonPauline vocabulary, the dependence of the author on Pauline phrases, and the possibility of separating genuine fragments from the rest. Yet he will feel also the artificiality of the way in which Pauline phrases are borrowed and ofien slightly altered, the great improbability of the invention of such a detail as I $5^{23}$

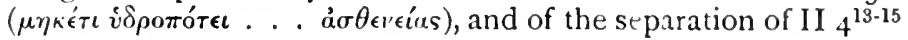

1 The queslion of the release of St. Paul from the Roman imprisonment of Ac $2 S$ is not of primary importance with regard to the authorship of these letters. For (i) either on the supposition of the Pauline or of a non-Pauline authorship it is possible that $2 \mathrm{Ti}_{4}^{4-21}$ (for which the release is mainly needed) consists of notes written at a different date and incorporated alterwards, whelher intentionally or accidentally, by a later editor or scribe. (ii) The arguments from the state of the ecclesiastical organization and from the vocabulary would still remain.

let there seems no valid reason for doubling the tradition that St. Paul was releaced. It is a natural inference from Ac $2 S^{: 30}$ (cf. I'arry, p. xv) ; it is at least a pissible, hough perhaps not the most probable, inference from

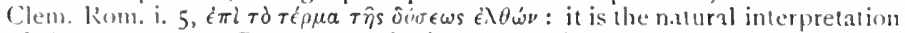
of the Muaturan Canon. "profectionem Pauli ab urbe ad Spaniam"; and if I)r. (Billond (Speatier's Comm., Lomans, pp. 24-29) is right, as seems very probalile, in treating Ro 16 as a letter written by Si. l'aul o kome after his release, $w$ th messages to the friends whom he hat made during the two years' impriscment, this supplies first-hand evidence of contemporary date. 
from ${ }^{20.21 a}$ if they were parts of one genuine letter carefully preserved because it was genuine. Yet neither for problems of doctrine nor of exegesis is the question of primary importance ; if they were not written as they stand by St. Paul, they probably in. corporate some earlier notes of his (v. infra, p. xxxii); the whole was written by one who thought himself a devoted follower of St. Paul, whose mind was steeped in the very language of St. Paul's letters, who has tried to express his spirit ; and this attempt was accepted by the Church as true to its memory of what St. Paul had been and tauyht. They may seem to lay more stress on a regulated life and an ordered ministry than the earlier letters; but those letters showed him from the first conscious of the need of such regulation, and the consciousness grows with each letter; the regulation of community life in $\mathrm{I}$ and $2 \mathrm{Th}$. is followed by that of citizen life in Ro., of family life in Col. and Eph. (cf. W. Lock, St. Paul, the Master Builder, c. 4). As the thought of the imminent Parousia recedes before the sense of the work to be done in the world and the sense of the reality of the abiding Presence of Christ in the heart, so the problem of the Christian society to the world around it becomes more pressing. The experience of many a missionary in China or in India in the present day shows how quickly the converting missionary has to organize and regulate his group of converts (cf. T. M. Lindsay, The Church and the Ministry, 1903, p. 139). All the letters are a sufficient proof that the mystic who lives "in Christ," in whom "Christ" lives, is also the practical statesman, caring for all the Churches, providing things honest in the sight of men; the chief message of him who was constrained by the love of Christ has been defined as loyalty to the Christian society (cf. Royce, The Problem of Christianity); and this picture of the man and of his message is reproduced in these letters.

Integrity.-On the theory of Pauline authorship there is $a$ priori little reason to doubt the integrity. A private letter by an Apostle would naturally be preserved entire; yet when it was first made public and canonical an editor might add his comments and illustrations and bring up to date some of the regulations. Thus Professor C. H. Turner (Inaugural Lecture, Oxford,

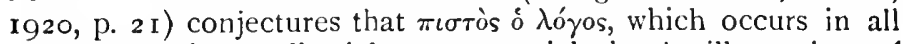
three letters, is an editorial note; so might be the illustrations of

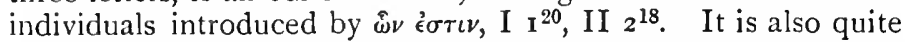
possible that fragments of other letters should have been combined, whether intentionally or accidentally, at the end of the genuine letter.

On the theory of the non-Pauline authorship of the letters as they stand, the problem will differ in each, according as the later 
editor has or has not attempted to incorporate earlier Pauline fragments.

Each letter must therefore be considered separately.

I Timothy.-Assuming the Pauline authorship there is no conclusive reason for treating any part as a later insertion. Yet the

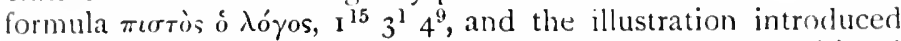

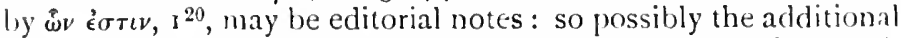
note about $\delta$ sako'm and the reasons alleged for it in $3^{12.13}$ (n.b. $\delta(\alpha \kappa o v \eta \dot{\gamma} \sigma \alpha \nu \tau \epsilon$ and $\beta \alpha . \theta \mu o ́ v) 6^{10}$ (n.b. a $\left.\pi \epsilon \pi \lambda \alpha \nu \dot{\eta} \theta \eta \sigma \alpha v\right)$; also the whole section $5^{9-16}$ the regulation of the viduate, the section which more than any other suggests a late date; and the apparent reference to future false teaching in $4^{1-5}$; and the allusion to "knowledge falsely so called" in $6^{20}$.

Assuning the non-Pauline authorship there is less ground still for doubling the integrity, though it is almost incredible that $\mathbf{1}^{12-16}$ $5^{23}$ are not genuinely Pauline; and von Harnack, who dates the writing of the Epistle between 90 and roo, still regards the sections on the bishops and deacons (c. 3 ), and the discipline over the presbyters (c. 5$)$, and the last verses $\left(6^{17-21}\right)$, as additions of a later writer between A.D. I 40 and 150 (Chronologie, i. Pl). 48085). Critics have separated a genuine Pauline letter in $\mathrm{I}^{1-10.18-20}$

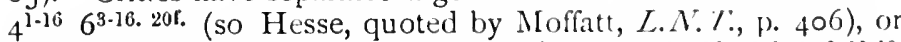
even two, one written from Corinth ( $1^{3 f}, 18-202^{1-10} 4^{12} 5^{1-3 .} 40-6.11-13$. 19-23. 2+f. $)$ and one from Cæesarea (1 ${ }^{12-17} 3^{14-16} 4^{1-11.13-16} 5^{\text {if. }} 6^{17-19}$ ${ }^{5-11} 6^{2-16.20 .21}$ ) (so Knoke $a p$. Moffatt, l.c.). But such re-arrangement is most unlikely, and the uniformity of style is almost conclusive against such hypothesis (so Moffatt, l.c., and Harrison).

There are, however, very possibly some dislocations of the text. Ewald would transpose $1^{3-11}$ and $1^{12-17}$, and place $3^{14}-4^{16}$ after $6^{2}$, but without any necessity. More probably $6^{17-19}$ should follow or precede $6^{1.2}, 5^{23}$ might follow $4^{12}, 5^{16}$ after $5^{4}$. Parry would arrange the section $5^{3-9}$ in the order 3.4 .8 .7 .5 .6 .9 .

2 Timothy. - The Pauline authorship of the whole Epistle as written at one and the same time in its present form is open to two objections: (a) Throughout the whole two different thoughts are intertwined; the one, "come and join me at Rome," the other, "Io your work as an Evangelist at Ephesus and hand on your work to others." "These are not really inconsistent, as the absence from Ephesus for a visit to Rome may have been the reason for the command to hand on his teaching to others, and the advice about the nature of the teaching may be meant chiefly for those who were to take 'Timothy's place. But the possibility remains that two letters have been combined, one private and jersonal $\left(4^{9-21}\right)$ to which the personal greeting belongs $(22 a)$, the 
other more general and pastoral $\left(\mathrm{I}^{1}-4^{8}\right)$ to be communicated to others with the plural greeting $\left({ }^{22 b}\right)$. If these two are separated the apparent inconsistency disappears.

(b) But, further, there are great difficulties about the unity of $4^{9-21}$. It is difficult to fit the allusions into St. Paul's life, as known from the Acts, and there are inconsistencies within the paragraph itselt. The command in ${ }^{21}$ seems scarcely needed after that in 9,11 scarcely consistent with ${ }^{21}$; the double salutation in 22 needs explanation. It is therefore most probable that an earlier note, or perhaps more than one earlier note, from Paul to 'Timothy, has been, whether intentionally or unintentionally, added to the main letter at the end, as apparently Ro I 6 was added to $\mathrm{I}-\mathrm{I} 5$. The most probable suggestion is that of $\mathrm{Mr}$. Harrison ( $P$. Epp.), who distinguishes three separate notes written at separate times, which can be fitted into the structure of the Acts :

(i) 13. 14. 15. 20. 21a, written by St. Paul, while in Macedonia (Ac $19^{22}$ ), after visiting Troas $\left(2 \mathrm{Co}_{2}{ }^{12}\right.$ ) on the third missionary journey, to Timothy after he had returned from Corinth to Ephesus. This is possible, but it is hard to account for the separation of the two parts of one short note 13-15. 20.21a when reproduced. (For a very similar reconstruction, cf. McGiffert, Christianity in the Apostolic Agre, p. 400.)

(ii) 16. 17. $18 \mathrm{a}$, written from Casarea (Ac $23^{25}$ ), the first defence referring to Ac $22^{1}$, the I.ord's standing by him to the appearance in $\mathrm{Ac} 23^{11}$. This is the least happy suggestion. The verses include what is called elsewhere (p. 28) the non-Pauline meaning of $\pi \lambda \eta \rho \circ \phi \rho \rho \eta \theta \hat{n}$, and St. Paul could scarcely have expected any one to stand by him on the occasion of Ac $22^{1}$.

(iii) 9. 10. 11. 12. 21, written early in the imprisonment at Rome to Timothy at Lystra, pressing him to come quickly. This leaves the apparent inconsistency between ${ }^{10}$ and ${ }^{21}$ still existing.

Without feeling entirely satisfied with all these details, I am inclined to think that ${ }^{9 \cdot 22 a}$ consists of earlier notes, and to regard the whole Epistle as Pauline, $\mathrm{I}-4^{8}$ written from Rome, during a second imprisonment, $4^{9-22}$ at some earlier times.

Those who treat the present form of the letter as due to a later editor still think that it retains some earlier Pauline fragments besides those in $4^{9-22}$. Various suggestions will be found in Moffatt (L.N.T., p. 400); but Mr. Harrison's is again the most probable. He treats the following as a farewell letter to Timothy, from. St. Paul at the end of the first Roman impris. onment, after his final trial and condemnation : $\mathbf{1}^{1 \text { 1a. } 2.16-18} 3^{10.11}$ $4^{1-8}$. But the allusions to Timothy's childhood and parentage $\left(\mathrm{I}^{5} 3^{14 .} \mathrm{1}^{5}\right)$ seem at least to carry their own credentials, and these to outweigh linguistic differences. 
Titus.-On the theory of Pauline authorship there is no reason to suggest editorial redaction or dislocation by scribes.

Some who ascribe the letter to a later editor think that genuine Pauline fragments are embodied. Von Soden finds Pauline materials in $\mathrm{I}^{1-4} 3^{12.13}$; McGiffert, in $1^{1-6} 3^{1-7.12 .13}$; Harrison only in the short address Ilav̂̀os Tít $\omega$ and $3^{12-15}$, which he regards as written by Paul from Western Macedonia (Ac $20^{2}$ ), perhaps having already preached in Illyricum (Ro $15^{19}$ ), to 'l'itus who is still at Corinth on the mission of $2 \mathrm{Co}_{2}{ }^{13}$, and who on the receipt of this letter joins him at Nicopolis with the good news of $2 \mathrm{Co}_{7}$, which led to the writing of 2 Co $1-9$. But this ignores the implication of 2 Co $7^{5} 8^{1} 9^{2}$, that the whole of 2 Co. was written from Macedonia, and it is difficult, though possible, to reconcile it with Paul's intention to spend this winter at Corinth, ${ }_{1}$ Co $16^{6}$. It is also noticeable that these four verses contain six words or meanings which are non-Pauline, vopєкóv, $\lambda \in i \pi \omega$, oi

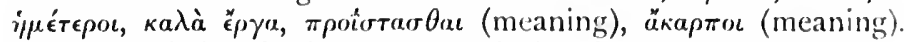
If the linguistic criterion were conclusive these verses would have to be condemned.

Order of composition.-On the theory of Pauline authorship I 'Ti. and 'Tit., in both of which St. Paul is free to move about, clearly precede $2 \mathrm{~T} \%$. when he is a prisoner in expectation of death. 'Tit. perhaps preceded $\mathrm{r} \mathrm{Ti}$. as simpler and dealing less with organization, but they may well have been written about the same time, the differences being adequately explained as due to the different circumstances of Crete and Ephesus.

Those who accept the theory of a later editor generally prefer the order 2 'Ti., Tit., I Ti. (cf. von Soden, pp. $154 \mathrm{ff}$; Moffatt, Lit. N.T., pp. 559-60). The chief reasons urged are (i) the greater number of personal allusions in II, and the fact that the earlier notes in $4^{9-22}$ have been annexed to it point to its being nearer to the lifetime of St. Paul; but the whole circumstances are more personal as between Paul and 'l'imothy, and the position of the notes may be purely accidental, the work of a scribe.

(ii) The greater definiteness in describing the false teachers in 'Tit. and I, and the greater severity in the way they are treated, e.g. contrast $112^{24} 4^{2}$ with Tit $3^{11} \mathrm{I} \mathrm{I}^{20}$ : but the passages in II are not dealing directly with teachers but with tendencies, those in 'Tit. and I with definite persons. The references to Hymenæus $I_{1} 1^{20} 112^{18}$ do imply greater severity, but these may be notes added later (cf. poxxxi).

(iii) Possible literary dependence of Tit. and I upon II and upon I J, e.g. I $1^{4} 4^{7}$, 'Tit $3^{9}$ upon II $2^{23}, I_{2^{7}}$ upon II ${ }^{11}$, I $4^{\prime}$ upon II $3^{\prime}$ (von Soden, p. 155), and again 'l'it $2^{3.5}$ upon I $\mathrm{P}^{13-16},{ }^{6-9}$ upon I $\mathrm{P} 5^{1-4}, \mathrm{I}_{2^{9-11}}$ upon $\mathrm{I} \mathrm{P}^{1-6}, \mathrm{I} 3^{16}$ upon I P $3^{18-22}$ (von Soden, P. I 74): but in no case is there 
proof of literary dependence, they may all be independent treat ment of similar subjects; nor is there any clear proof of the priority of 1 Peter.

\section{TExT.}

The authorities for the text are the same as for the other Pauline Epistles, except that these Epistles are lost from B and that we have a conmentary by Jerome on 'Titus. It will be sufficient to refer for the main problems to Sanday-Headlam, Romans, Introd. $\$ 7$, and to the articles by C. H. Turner in Murray's Ill. Bibl. Dictionary, and by J. O. F. Murray in II.D.B. Suppl., who has a careful examination of the Syrian readings in I Timothy, and to B. Weiss, Tivlivitik der Paul. Briefe, T. und $U$. xiv. 3 .

An examination of the variants quoted in lischendorf or in Souter shows that by far the greater number are unimportant and almost accidental. Even these are interesting as illustrating the habits and aims of scribes. Some are purely accidental, e.g.

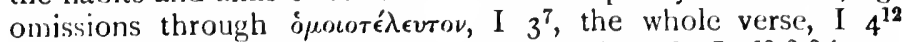

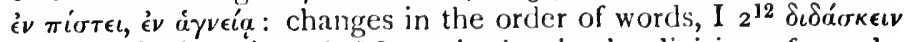

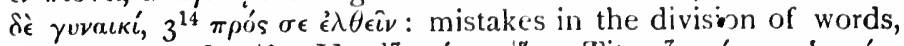

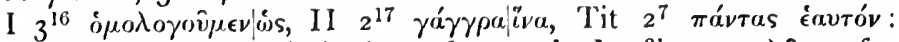
mistakes through similarity of sound, I $5^{21} \pi \rho \sigma \sigma \kappa \lambda \hat{\eta} \sigma \iota v$ for

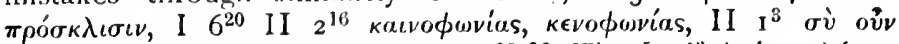

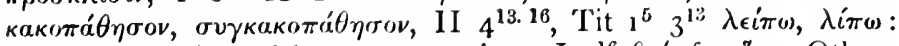
mistaken reading of letters, so perhaps I $3^{16} \theta \epsilon$ ós for ös. Others are semi-conscions reminiscences of cognate passages, I $\mathbf{I}^{\mathbf{1}}$

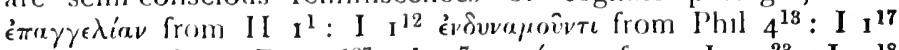

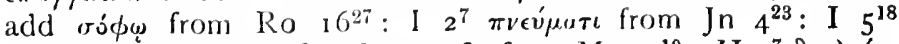

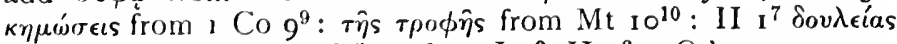
from Ro $8^{15}$ : Tit $\mathrm{I}^{4}$ add $\epsilon^{2} \lambda \epsilon o s$ from I $\mathbf{I}^{2}$, II $\mathbf{I}^{2}$. Others are more conscious attempts to improve the text: sometimes to make the

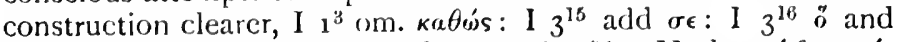

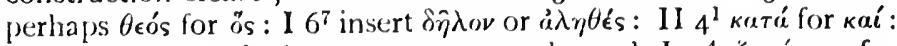
sometimes to substitute a more usual word, 1 $1^{4}$ לy rijoses for

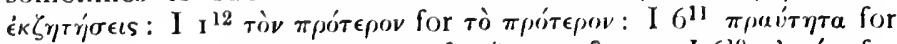

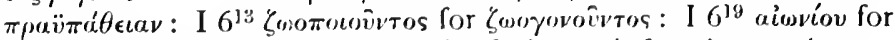

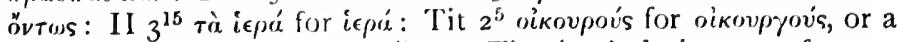
more usual form iva $\sigma \omega$ ppovílowtv, Tit $2^{4}$ A desire to enforce a moral duty may possibly underlie I $5{ }^{5}$ speret, instet, for sperat, instat.,

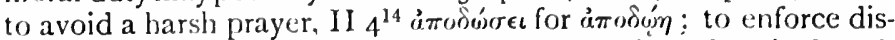

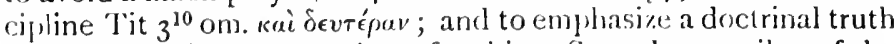
I $3^{16} \theta$ cós for os : but sce above for this. Some later scribes of the minuscules add facts apparently from apocryphal sources, e.g. II

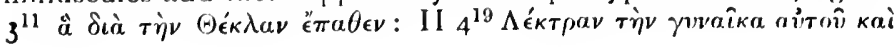




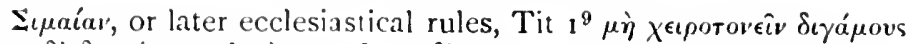

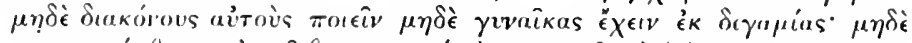

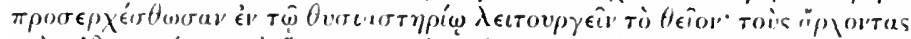

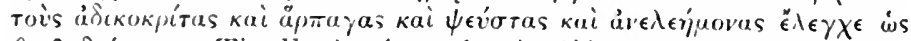

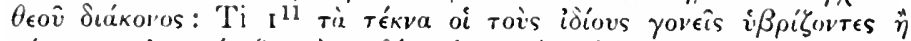

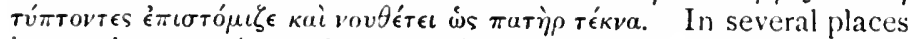
interesting questions of punctuation arise, vid. note on $\mathrm{I}^{5} 3^{1} 4^{9}$, II $2^{2.11} 4^{1}$, Tit $2^{7.9}$. On I $2^{4} 4^{10} 6^{4}$, II $2^{15} \mathrm{G}$ has the marginal note "goddiskalkon" or "cont goddiskolkon"; a hint that these texts refute the predestinarian views of Godeschalk (cf. Scrivener, 1. 122 ).

IV.-H. allow possibilities of variation of reading in 46 p!aces. The majority of these affect the order of words, 'I or Xpertós 'I zooves, I $\mathbf{I}^{16} 6^{\mathbf{1}}$, Tit $\mathbf{I}^{\mathbf{l}} \mathbf{2}^{\mathbf{1 3}}$; the insertion or omission of the article, I $6^{11}$ II $2^{18}$; a variation of tense, I $1^{12.18} 4^{6}$, II $3^{10}$ $4^{1.13 .16}$, Tit $\mathrm{I}^{8} 3^{13}$; of voice, I $5^{8.16}$; of number, I $2^{8} 6^{8}$; of punctuation, I $3^{1} 6^{2}$, all making some slight difference in meaning, but none that requires discussion.

The following are the more important. [The authorities quoted are from Souter except where otherwise stated.]

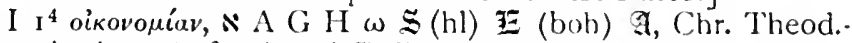

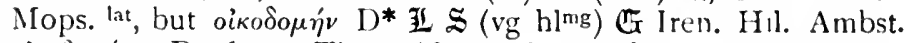

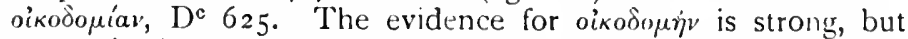
оікоиона $а$ is perhaps the more likely to have been altered; it

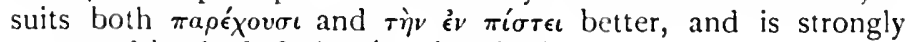
protected by $\dot{\omega} \varsigma \theta \epsilon o \hat{v}$ оiкоr

I $\mathrm{I}^{15} \dot{a} v \theta \rho \omega ́ \pi w o s$, humanus, $\mathfrak{Z} \mathrm{vt}^{\mathrm{r}}$ only, but also in Latin MSS known to Jerome (ad Mrariell., Ep. 24); so, too, in Ambst, Julian, and sometimes in Augustine, both here and in $3^{1}$ where I) also has it. The MSS authority is not strong, but the correction from $\pi \iota \sigma \tau o ́ s$ is unlikely (but rid. IV.-H., N'otes on Select Readingrs on $3^{1}$ ), whereas the assimilation to $\pi \iota$ orós in $4^{9}$, II $2^{11}$, Tit $3^{8}$, where there is no variant, is very probable. It is therefore possibly right, and the meaning will be "true to human needs" (cf. Ambst. "ut hominem peccatis ablueret . . . ut plus esset adhuc in beneficiis humanis ... presidium tulit homini... conversationi humanæe se miscuit "), and so akin to $\dot{\eta} \phi(\lambda \alpha \nu \theta p \omega \pi i$ i rov $\sigma \omega \tau \hat{\eta}$ pos $\theta \epsilon o \hat{v}$, 'I it $3^{4}$. So in $3^{1}$, if the words are there to be joined with the preceding verses.

I $2^{1} \pi u p a \kappa a \lambda\left(i\right.$, almost certainly right, cf. ${ }^{8}$, and the direct

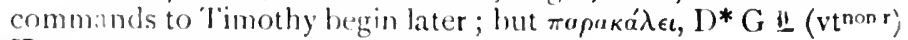
琶 (sah) Hul. Ambst. is possible; cf. $6^{17}$.

I $3^{1}$. Vil. note on $\mathbf{I}^{15}$.

I $3^{16}$. 05 is accepted in all critical editions. It was probably. altered to $\tilde{o}$ in order to agree with $\mu v \sigma \tau \eta \dot{p}$ pov', and to $\theta$ tós possibly by accidental misreading, or to supply a rominative, or. less 
likely, for dogmatic definiteness. For a full examination of the evidence, cf. Tischdf. ad loc.; W.-H., Select Readings, p. 134.

I $4^{2} \dot{a} \pi \epsilon^{\prime} \chi \epsilon \sigma \theta \iota$. There is no variant, and no change seems necessary ; cf. $2^{12}$ where $\dot{\epsilon} \pi \iota \rho \hat{\epsilon} \pi \omega$ has to be carried on from oúk

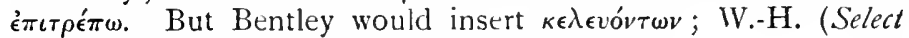
Readings) conjecture $\hat{\eta} a \tilde{a} \pi \tau \epsilon \sigma \theta a \iota$ or кai $\gamma \in v^{\prime} \epsilon \sigma \theta a \iota$.

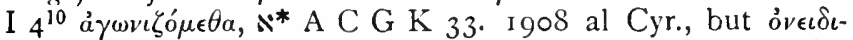
$\zeta o ́ \mu \epsilon \theta \aleph^{* c} \mathrm{D} \omega$ verss. Orig. Chrys. Ambst. Theod.-Mops. lat. 'I here is thus strong support for o ${ }^{\prime} \epsilon_{\epsilon} \delta \iota \zeta^{\circ} \mu \epsilon \theta a$, which may be right (especially if $4^{10}$ is the faithful saying), and which is unlikely to have been substituted for $\dot{a} \gamma \omega \nu \iota \zeta{ }^{\circ} \mu \epsilon \theta a$ : but $\dot{a} \gamma \omega \nu \iota \zeta^{\prime} \mu \epsilon \theta a$ suits the context better; cf. $\gamma v_{\mu \nu}^{\prime} a \zeta \epsilon, \gamma v \mu \nu a \sigma i a$, and is protected by $6^{12}$, II 4 .

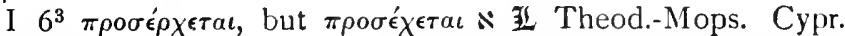
Lucif. Ambst. "acquiescit," "intendit." There is no necessity

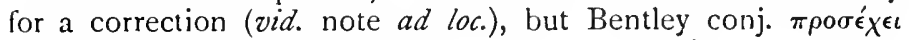
from $I^{4}$, which was doubtless in the writer's mind. IVas the original reading $\pi \rho \circ \sigma \epsilon_{\chi} \in \iota$ toîs ?

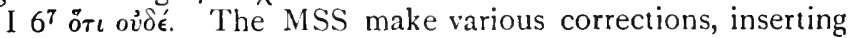
$\delta \hat{\eta} \lambda o v, a \dot{a} \lambda \eta \theta \dot{\epsilon} s$, verum, haud dubium: Hort would omit o̊ $\tau \iota$ as an.

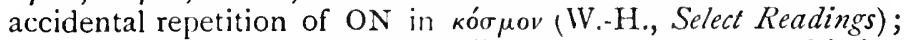
Parry would invert the order ov $\delta$ " õ $\tau$, " not to speak of being able to carry anything out"; but is any change necessary? vid. note ad loc.

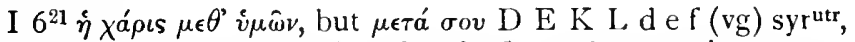
Arm. Eth. Thdrt. Dan. (Tischendorf), perhaps points to a combination of two letters; or a change to the plural would have been natural when the Epistle was treated as canonical and as affecting the whole Church.

II I ${ }^{13} \tilde{\omega}_{\nu}$ all MSS. Hort conj. $\stackrel{o v}{ }$, "hold as a pattern of sound doctrine that doctrine which . .." (IV.-H., Select Readings); but the attraction, though unusual, is possible; cf. v.l. on Tit $3^{5}$; Blass, $§ 50.2$.

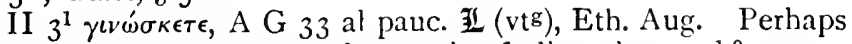
accidental change, perhaps due to the feeling that $\mathrm{vv}^{1-9}$ are so much more general than $2^{22-25} 3^{10 \mathrm{fr}}$.

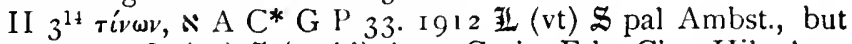
rivos $C^{\mathrm{c}} \mathrm{D} \omega \mathbf{l}(\mathrm{vg}) \mathbb{S}(\mathrm{vg}$ hl) Arm. Goth. Eth. Chr. Hil. Aug. Theod.-Mops. lat, probably an alteration under the impression that the reference is to the Apostle; cf. ${ }^{10.11}$.

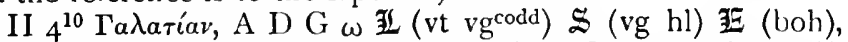

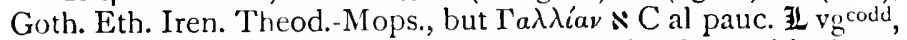
Eus. Epiph., probably a later change to avoid the ambiguity of radariav: and if so, a witness at that time to the belief that St. Paul had been in Gaul ; cf. W.-H., Select Readings, ad loc. 


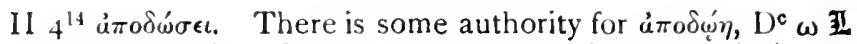
$\left(v^{d} \mathbf{v g}\right) \$(h l)$, Diod. Chrys. Theod.-Mops. lat, and this is the reading more likely to have been altered to avoid the appearance of an imprecation (cf. Tischdf. ad loc.); but the indicative is

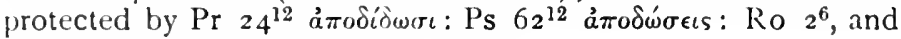
the spirit of Ro $12^{19}$, and cf. ${ }^{16}$ infra.

II $4^{22}$ : cf. note in I $6^{21}$.

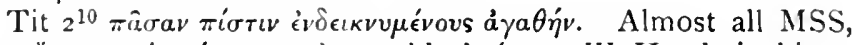

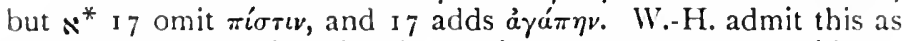
a possible alternative; but it may be an attempt to avoid the awkwardness of the position of a $\gamma a \theta \dot{\eta} v$.

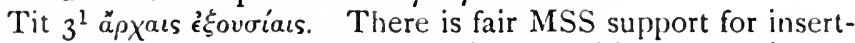
ing кai : it may have been a conscious addition to avoid the asyndeton, but may it not have accidentally dropped out after äpXaıs?

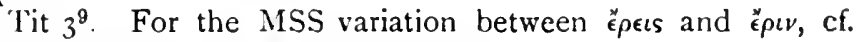
IV.-H., Notes on Orthographi1, p. 157.

Tit. $3^{10}$ kai $\delta \in v \tau$ épal. The MSS authority is almost unanimous for the insertion of these words, but with differences of

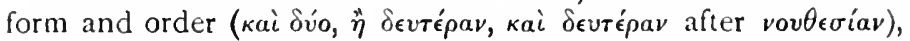
and they were omitted in one MS of the Vetus Latina, by other MSS known to Jerome, as well as by Irenæus, Tertullian, Cyprian, Ambr., Ambrst., and Augustine $\frac{3}{3}$. Their omission, if genuine,

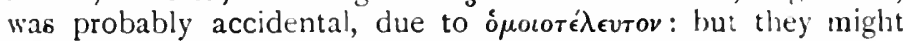
have been inserted later to relax the severity of $\mu i a v$.

\section{Later Influence of the Eptstles.}

These Epistles had great influence from the first, affecting the Liturgical services of the Church at once, and giving a model on which were framed later the Church Orders and treatises on Ministerial Character.

(i) Liturgical.-The most direct, immediate, and permanent effect is to be seen in the introduction of prayer for all men and for kings and rulers into the Eucharistic Liturgy. This is already found in Clem. Rom. i. 6r, and Polycarp, Ep. 1 2, and remained permanently in the Eastern Liturgies (vid. note on $\mathrm{I} 2^{2}$ ), and the exact words are often borrowed from $\mathrm{I} \mathrm{Ti}^{1-4}$ and the same reason given for the prayer; cf. Brightmall, L.E. $I V$. i. pp. 55, 92, I $4,128,168,288$, "make wars to cease in all the world and scatter the divided people that delight in war, that we may lead a cuiet and pleasant life in all sobriety and godliness" (from the Persian nite), 33.3 .

But apart from this passage the language of these Epistles is often borrowed in the Liturgical prayers: the titles of God, "King of the ages" (pp. 32, 5 I, 162, 200). "King of kings" (pp. 4 I, 128). 
dwelling in light unapproachable (pp. 5, 26, 263, 369, 41 2 , 436), who cannot lie (p. 170), the Saviour of all men, especially of them that believe (p. 263): the titles of Christ, as "Our Saviour" (p. 24), "our (great) God and Saviour" (pp. 9, 33, 97, 103, 1 I3, I 1 4, I 32, 322, 337, 444), "our Hope" (pp. 5, 21, 322): His work as saving sinners (p. 394), giving His life as a ransom (p. 347), as abolishing death (p. 232), as preparing a peculiar people, zealous of good works (pp. 264, 326) : the Christian life as the real life, $\tau \hat{\eta}$ s ö $\nu \tau \omega s \zeta \omega \hat{\eta} s$ (p. 4), the good fight (pp. 94, 352), as requiring a pure heart (pp. 1 16, 1 23, 1 35, 293, 295), a pure conscience (p. 34), as begun in the laver of regeneration (pp. 4, 157, 315): the work of the Episcopate as "rightly dividing the word of truth" (passim). These are the most frequent: Dr. Brightman would add the doxology $\delta o ́ \xi \alpha$ кai $\tau \iota \mu \eta^{\prime}$, the combination "with faith and love," the prayer, "The Lord be with thy Spirit," as borrowed from I I ${ }^{17}$ ${ }^{14}$, II $4^{22}$; but these seem more doubtful.

In the Roman Mass it is the practice that when the Epistle is read: "si desumpta est ex Actibus Apostolorum incipit, In diebus illis; si ex epistolis, Fratres; si ex epistolis Pauli pastoralibus, Carissime." This has perpetuated the note of personal affection struck in $11 \mathrm{I}^{2}$.

In the English Ordinal, $\mathrm{x} \mathrm{Ti} 3^{8-13}$ is an alternative Epistle in the Ordering of Deacons; $1 \mathrm{Ti} 3^{1-7}$ in the Consecration of Bishops; and the language of Tit $\mathrm{I}^{9} 2^{8.12}$ underlies the questions addressed to the Bishop before Consecration; $2 \mathrm{Ti} \mathbf{1}^{6.7}$, I $\mathrm{Ti}$ $4^{13-16}$ the exhortation after Consecration; $2 \mathrm{Ti} 4^{2}$, I ${ }^{\mathrm{Ti}} 4^{12}$, $2 \mathrm{Ti}_{4}^{7.8}$, the final prayer.

The prayer in the General Confession at morning and evening prayer "that we may hereafter live a godly, righteous and sober life," is taken directly from 'Tit $2^{12}$.

(ii) Ecclesiastical.-(a) The Didache.-This resembles the Pastoral Epistles in laying down rules for the character of the Christian Life in general and of the ministry in particular: but it deals more fully in details about the Ministers, their testing, their election, their maintenance, and their relation to the Apostles and prophets and with the Sacraments. It offers some interesting points of illustration (cf. notes on $I_{2} 2^{8} 5^{17} 6^{17.20}$ ), but neither quotes these Epistles, though quoting some other Epistles of St. Paul, nor shows any verbal correspondence with their language even when dealing with similar subjects (cf. Did. 2, the summary of the Commandments, with $\mathrm{I}_{1}{ }^{8-10}$; Did. 5 , the list of heathen vices, with II $3^{2-5}$; Did. $4, \S 3$, judicial action, with I $5^{21}$; Did. $4, \S$ Io, masters and slaves, with $16^{1.2}$, Tit $\left.2^{9}\right)$. The tone of the Didache is more akin to I Thessalonians than to the Pastoral Epistles; on the other hand, there is no trace of our author having used the Didache. They are two entirely independent documents, one 
dealing with a Church in a mainly Jewish environment, the other with Churches face to face with Gentile life.

(b) The Egyptian Church Order is now recognized as the earliest of the extant Church Orders, and as being the a $\pi$ orrod $(x i]$

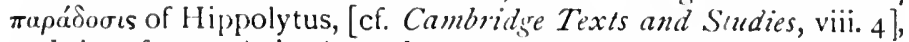
and therefore early in the 3 rd century. But this, too, shows little influence of the l'astoral Epistles. Its tone is ecclesiastical rather than ethical : it does lay much stress on the character of candidates for baptism, but in dealing with the ministry it is mainly an Ordinal, dealing with the method of appointment and the prayers to be used at the ordination of Bishops, Priests, and Deacons, the setting apart of IVidows, Readers, Sub-Deacons for minor olfices, the administration of Baptism and the Eucharist, the rules for fasting, private prayers, attendance at church, the sign of the cross.

(c.) The so-culled Canons of Hiffolytus.-All the later Church Orders, of which it will be sufficient to take this as a specimen, make much more use of the Pastoral Epistles. These Canons quote them twice: $\$ 7$, "Episcopus sedatus sit sicut de illo in Apostolo scriptum est" =I $3^{2}$ : $\$ 217$, "secundum mandatum apos:olorum [? leg, apostoli], dum venio attende lectioni" $=\mathrm{I} 4{ }^{13}$, and there are frequent reminiscences of their directions or actual vocabulary, e.g. $\S \mathbf{I}$, "de fide sacra sana quæ est de domino nostro Jesu Christo" =I 63 $: \S 4 \mathrm{I}$, "mores sine peccato coram omnibus hominibus" =I $3^{7}: \S 5^{8}$, "duplici honore afficiatur" =I $5^{17}: \S 59$, "Viduis honos tribuntur" $=\mathrm{I} 5^{3}: \$ \S 8 \mathrm{I}-\$_{7}$, on women's dress, esp. 87 , "neque tu quæ pretiosorum lapidum et margaritarum ornamentis superbis tam pulchra es ut illa quæ sola natura et bonitate splendet" = I $2^{9 \cdot 15}$ : $\$ 88$, "neve loquatur in ecclesia, quæ est domus Dei" $=\mathrm{I} 2^{11} 3^{15}$.

All these later orders take their tone and many details from the Pastoral Epistles, but do not seem to have treated their regulations as necessarily of permanent obligation: e.g. in some, celibacy is put forward as the ideal of a bishop, "It is good that he be without a wife, but at any rate that he have been the husband of one wife only." Test. Dom. Nostri, § 20 (with Cooper and Maclean's note).

Harnack attempts to show the dependence of the Pastoral Epistles on an early "Kirchenordmeng" which underlies th: Earliest Church Orders (Chronologie, i. p. $483 ;$ T. und U. ii. 5), but in most instances quoted the priority seems clearly on the side of the Pastoral Epistles, and in none is their dependence clear.

(iii) I'astoral.- The ethical influence of the Pastoral Epistles has been even more emphatic and permanent. 'Two illustrations will be sufficient.

St. Chrysostom, De Sacerdotio, deals with the dignity and respronsilility of the Priest's office, dwclling even more than 
the Pastoral Epistles on the spiritual peril to which the holder is exposed; he emphasizes the difficulty of dealing with individual sous. and the importance of intellectual ability for the needs of teaching. But St. Patul is his ideal throughout; to his teaching he most frequently appeals: he quotes his requirements for the

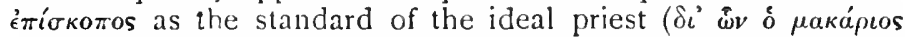

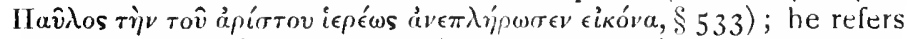
directly to I $3^{1.17}$ (S I 35,228 ), II $2^{25}$ (S I 19), and adopts the language of $13^{6} 4^{12}(\$ 163)$, ' Tit $2^{14}(\$ 88)$. His rules for the treatment of widows (\$ $299 \mathrm{ff}$.), and his warning of the danger to a priest of sharing the sins of others, help to explain the meaning of $\mathrm{I} 5^{5 \mathrm{tr}}$ and ${ }^{22}$.

St. Gregory the Great, Regula pastoralis liber. This book is even more closely akin to the l'astoral Epistles, as its main themes are the character of the Pastor and the different ways in which he must deal with different classes of men both in preaching and in private intercourse. St. Paul is for him "predicator egregius" the "magnus regendi artifex": his subjects follow the lines of I $3^{1-7} 5^{1-6^{2}}$, Tit $2^{1-9}$ : he also quotes $\mathrm{I} 4^{1.2}$ $5^{1.8 .23} 6^{1.10 .17}$, II $4^{1.2 .3}$, Tit $1^{9.15} 2^{15}$; but he uses as often , ther Epistles of St. Paul and the Old Testament, especially the Prophets and the Wisdom Literature, at times even the minute prescriptions of the Levitical Law. These are allegorized in a way that is always ingenious, often very apt, sometimes grotesque. But apart from this the whole tone is wise, spiritual, with a kten insight into human nature and the characters of men-in a word, worthy of St. Paul.

\section{Commentaries on these Epistles.}

[This list does not aim at being exhaustive; it represents those books which have been used for this edition; those asterisked represent those which are still of great value to the student. Fuller information on the Patristic Commentaries will be found in Hastings, D.B., Extra Volume, "Greek Patristic Commentaries"; Lightfoot, Galatians, Add. Note; Swete, Theodore of Mopsuestia, Introd. V.; a con plete bibliography of all that has been published on these Epistles since I880 in Harrison, The Problem of the Pastoral Epistles, App. III.; and a list covering the whole ground in Wohlenberg in Zahn's Kommentar.]

Cent. 11. Clement of Alexandria. A few notes preserved in Ecumenius.

Cent. 1II. Origen. A few notes on Titus only, mainly embodied in Jerome. 
Cent. Iv. **Ambrosiaster (ap. Ambrosii Opera, vii., ed. Benedict, Venice, 178I ; cf. A. Souter, Cambridge Texts and Studies, vii. 4), c. 375, written at Rome by an anony. mous layman, probably to be identified as a converted Jew named Isaac. Independent, practical and dogmatic, with special interest in questions of Church organization, and with illustrations from Jewish teaching and practice.

*** St. Chrysostom (ed. Field, Oxford, i 86 I ; Eng. tr., Tweed., Oxford, r843), Homilies, probably delivered at Antioch c. 385-95. Sound sensible exegesis, invaluable as interpreting the sequence of thought, the personal bearing and the spiritual application.

St. Jerome (ed. Vallarsi, vii. pp. 685-740), c. 388 , on Titus only. Generally sensible exegesis, with some strange mystical interpretations; pressing home with a satirist's outspokenness the moral and spiritual bearings; interesting in the account of his own studies and those of Origen.

Cent. v. Pelagius (ap. Hieronymi Op., ed. Benedict, xi.), c. 400-09. Short pointed notes, partly exegetical, partly moral and doctrinal; always shrewd and practical. (For a careful account, cf. Cambridge Texts and Studies, vol, ix., Cambridge, 1922.)

* Theodore of Mopsuestia (ed. H. B. Swete, Cambridge, 1880 , with most valuable notes; Migne, Putrol. Gr. 66), c. 4I5. Fragments only of the Greek extant in Catenæ; Latin tr. (c. 550) complete. Good literal and historical exegesis, with keen practical and theological interest, but tending to rationalize doctrine.

Theodoret (ed. C. Marriott, Oxford, vol. i., I852; vol. ii., C. M. and P. E. Pusey, I 870), c. 450. Clear, sensible, doctrinal, but mainly compiled from Chrysostom and Theodore.

? Cent. vi. Catena Anonyma (ed. J. A. Cramer, Oxford, I 84 I-44). Valuable, as containing extracts from lost earlier commentators, down to the $5^{\text {th }}$ century.

Cent. vilı. John of Damascus (ed. Le Quien, Paris, r 7 I2). Notes on a few passages; fairly full on I Ti. ; very slight on $2 \mathrm{Ti}$. and Tit.; mainly extracts from Chrysostom.

Cent. 1x. Ecumenius: Catena (Migne, Patrol. Gr. II9). Mainly abbreviated from Chrysostom, with extracts from others, especially Photius and Theodoret, and notes of his own, exegetical and doctrinal.

Cent. xı. 'Theophylact: Catema (Migne, Patrol. Gr. 125). Extracts, mainly from Chrysostom, but from a greater variety of previous commentators than in Ecumenius. 
Cent. xI11. St. Thomas Aquinas (ed. J. Nicolai, Lugduni, 1689). On the Vulgate, not on the Greek text : a careful examination of the meaning of each Latin word, of the reason why it is used, and of the structure of each sentence and paragraph. He shows a shrewd knowledge of human nature (vid. notes on Tit $1^{7-9} 2^{1-10}$ ), and illustrates from Aristotle and Cicero. His quotations also show the kinship of practical advice between the Epistles and the IVisdom Literature (Proverbs, Wisdom, Ecclesiasticus).

Cent. xvi. J. Calvin, Commentarii in NT, Berlin, 1833-34. Strong clear-headed exegesis, but dominated at times by controversial aims.

Cent. xvirr. ** J. A. Bengel, Gnomon Novi Testamenti (Tübingen, I 734, ed. 5, J. C. F. Steudel, I 835). Spiritual, epigrammatic, rich in beauly and suggestiveness.

**J. J. IVetstein, Novum Testamentum Gracum, Amsterdam, I 75I-52. A repertory of classical illustrations, especially valuable for these Epistles.

Cent. xix. H. Alford, The Nere Testament, ed. 5, I863. Always thoughtful and well balanced.

C. J. Ellicott, The Pastoral Epistles, ed. 4, 1864. Most thorough lexically and grammatically.

**H. J. Holtzmann, Die Pastoral-Briefe, Kritisch und Exegetisch behandelt, Leipzig, 1880. A masterly treatment of the problem, with verdict against the Pauline authorship.

B. Weiss in Meyer's Kommentar über das NT, ed. 5, Göttingen, I886. Careful introduction and execresis.

A. Plummer, The Expositor's Bible, 1888. Interesting analysis of the subject-matter.

***H. von Soden, Hand-Commentar zum NT, Freiburg. I $S_{9}$ I. Quite excellent in scholarly exegesis; the strongest statement of the case against the Pauline authorship.

J. B. Lightfoot, Biblical Essays, London, 1893, Essay xi. "The date of the Pastoral Epistles."

***Th. Zahn, Einleitung in das NT, vol. i. c. vii., Leipzig, i 897. The most thorough and learned defence of the Pauline authorship.

H. P. Liddon, London, 1897. I Timothy only. Careful analysis and good patristic illustrations.

E. Riggenbach, Kurzgef. Komm. z. d. bibl. Schriften, Mïnchen, I 898 . Terse exegesis, with suggestive analysis of the sequence of thought.

**J. H. Bernard, Cambridge Gk. Test., I 899. Thoughtful, interesting, with good knowledge. 
F. Field, Otium Norvicense, Pars Tertia, Cambridge, 1809. Exrellent examination of a few selert passages.

*: (;. Wohlenberg in Zahn's Kommentar zum NT, Leipzir, rgo6. Very careful work; independent, with subtle analysis of the thought, and interesting classical illustrations.

N. J. D. White in Expositor's Greek Testament, London, I9I0. Thoughtful.

*** M. Dibelius in Lietzmann's Handbuch zum NT, Tübingen, I9I3. Terse, pointed notes, with most valuable illustrations from pagan, especially religious sources.

**E. F. Brown, IVestminster Commentaries, I ondon, 1917. Useful illustrations from work as a missionary in India.

A. E. Hillard, London, r9ig. Excellent on the pastoral spirit.

**R. S. J. Parry, Cambridge, I920. Most scholarly.

**P. N. Harrison, The Problem of the Pastoral Epistles, Oxford, I92r. Indispensable on the linguistic arsuments against the Pauline authorship. 


\section{TIMOTHY}

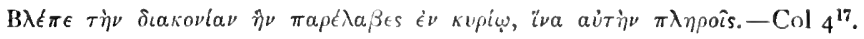

Historical situation.-There is no certain indication of the place at which the letter was written. St. Paul had been with 'Timothy at Ephesus, or possibly Timothy had come from Ephesus to meet him at some point on a journey that he was making to Macedonia (cf. the situation of Acts $20^{17}$ with $1^{3}$ ): St. Paul was bound to go forward, but was so much impressed with the dangerous tendency of some false teachers at Ephesus that he pressed Timothy to stay on in order to counteract them. St. Paul has continued his journey to Macedonia, and is perhaps now there: perhaps he has heard that all is not prospering in Ephesus: more probably his natural anxiety prompts him to write, for Timothy is still young $\left(4^{12}\right)$, naturally timid, liable to frequent illnesses $\left(5^{23}\right)$ : his hands need strengthening. Paul hopes to be able to return himself soon $\left(3^{14}\right)$, but he may be delayed $\left(3^{15} 4^{13}\right)$, so he writes at once (cf. the similar circumstances that led to the writing of $\mathrm{I} T h\left(2^{17}-3^{5}\right)$, and also I Co $4^{17-19}$, Philem ${ }^{22}$ ), to reinforce his charge about the false teachers, to lay down rules on certain points of public worship and the character of the officers in the Church, and to give Timothy guidance as to his own life and teaching.

General character.-In large parts of the letter the personal and local element is strongly marked-either in allusion to St. Paul's own life $\left(1^{1.3 .11 .12-16} 2^{7} 3^{14}\right)$ or to Timothy's character and circumstances $\left(1^{1.3 .18} 3^{15} 4^{6-16} 5^{23} 6^{11-13.20}\right.$ ) or to local conditions at Ephesus $\left(1^{6.19} 5^{15} 6^{3-10.17-19.21}\right)$. On the other hand, some sections are quite general and might have been sent to any Church (e.g. $2^{1-6.8-15} 3^{1-13} 5^{1-16} 6^{1.2}$ ), and the greeting is not to Timothy but to the Church. It is probable, therefore, that these parts at least were intended for public reading. It is further possible that the writer was thinking of a wider audience, and intending the more general parts to be circulated among other

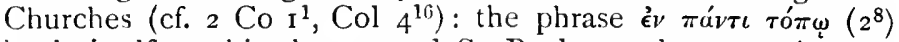
lends itself to this theory, and St. Paul was always anxious to secure uniformity of practice and order in his Churches (cf. 
I Co $\mathrm{II}^{16} \mathrm{I}^{33}$ ). Or the explanation may be slightly different : the general problems discussed in these sections are problems that would arise in every congregation: St. Paul must have had to deal with them again and again: and his teaching would have become stereotyped in some form which could be embodied without change when sent to a particular Church.

Date.-There is no reference to external events to throw any light on the date of writing. On the other hand, the many similarities with the subject and language of Titus prove that it was written about the sanne time as that Epistle, probably a little after, as the thoughts are fuller here. The similarities between both these Epistles and I P (cf. Introd. p. xxiv) point the same way, though the priority of $\mathrm{I} P$ is doubtful. The use of the Pauline Epistles, especially Ro. and Co., may imply adaptation by a later writer, but is consistent with repetition of the same thoughts by the same writer. The quotation of three "iaithful sayings" $\left(1^{15} 2^{15} 4^{9}\right)$, of a Christian hymn $\left(3^{16}\right)$, of lit.urgical doxologies $\left(1^{17} 6^{15.16}\right)$, of a Christian prophecy $\left(4^{1}\right)$, the possible allusion to some early form of creed $\left(6^{13}\right)$, and the possible, though not probable, reference to "Scripture" for a saying of the Lord $\left(5^{18}\right)$, all favour a comparatively late date, though not necessarily one later than St. Paul's life. Hence most editors who favour a non-Pauline authorship place this Epistle as the latest of the three (so von Soden, H.K., p. I 54 ; Moffatt, L.N.T., p. 560 ; McGiffert, $A . A$., p. 4 r 3 ).

For the evidence from Church organisation, the false teach. ing attacked, and the style, cf. pp. xvii ff.

Spiritual value.-(i) The chief contribution which the Epistle makes is the picture of the true Teacher and the true Teaching. The teacher eagerly pursuing righteousness, godliness, faith, love, patience, meekness $\left(6^{11}\right)$, keeping a good conscience $\left(\mathrm{I}^{19}\right)$, disciplining himself $\left(4^{8}\right)$, self-controlled in all respects $\left(3^{1-3}\right)$, free from the love of money $\left(3^{3} 6^{10}\right)$, a pattern for his people $\left(4^{12}\right)$, controlling his own family well $\left(3^{4}\right)$, treating his church as his own family $\left(5^{1-3}\right)$, growing in courage and boldness of speech $\left(3^{13}\right)$, free from favouritism and impartial in judgment $\left(5^{17-25}\right)$, keeping the commandment without spot, as he remembers God as the source of life and Christ Jesus as the example of courage, and looks forward to His reappearance to judge $\left(5^{21} 6^{14}\right)$. There is not the unveiling of the deepest motives of the minister of Christ, such as is found in 2 Co., but there is the practical outcome of such motives.

So, 100 , with the nature of the teaching: it is healthy and sane $\left(I^{10}\right)$, free from feverish excitement $\left(6^{4}\right)$, its standard and aim is godliness $\left(6^{3}\right)$ : it ains always at the central verities, love, 
faith, truth, a pure heart, a good conscience $\left(\begin{array}{ll}1^{5} & 2^{7}\end{array}\right)$ : it is impatient of aimless speculations, of old wives' fables, of all that hinders the work of God's steward $\left(\mathbf{I}^{4} 4^{7}\right)$ : it is loyal to the Apostolic teaching and based on the words of the Lord Jesus and the Gospel of the glory of the blessed God $\left(\right.$ I $\left.^{11} 6^{3}\right)$, and falls back quickly on great doctrinal truths $\left(1^{15} 2^{4.5} 3^{16} 4^{10}\right)$.

(ii) This high spiritual level is consistent with a regulated worship and an organized ministry. In the regulations, worship is first dealt with as giving the keynote for life: in all the churches prayer is to be offered for all mankind and for the rulers, regulations which have influenced all liturgies and have done much to promote a missionary spirit based upon a belief in human nature, and also helped to favourable relations between the Church and the State. This carries the duty of obedience to government as given in Ro 13 to a higher level $\left(2^{1-7}\right)$. The following regulation about the relation of men and women at service does not add to that in I Co.

Some organization of the ministry is assumed as already existing, but there is a clearer picture than elsewhere of the relation of the deacon to the "bishop," of the possibility of passing from one grade to another, a fuller reference to the work of deaconesses and to the order of widows.

But it is a striking fact that a church so organized is not left independent, to deal with its own difficulties: it is subordinate to the Apostle's delegate, who has to control the teaching, to arrange for the services, to exercise discipline over the presbyters, and for these tasks stress is laid upon his ordination: he has received a definite gift: stress is laid upon its "given-ness" $\left(\chi \alpha ́ \rho \iota \sigma \mu \alpha, \epsilon^{\prime} \delta \delta \theta \eta, 4^{14}\right)$ : given by prophecy and the laying on of hands of the presbytery: it is in the strength of such prophecies

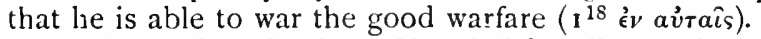

Both as a handbook of Church Discipline and Worship, and as a treatise on ministerial character, the Epistle has bad a great influence on the services, the organization, and the literature of the Church ; cf. Introduction, p. xxxviii.

\section{Analysis of THE EPISTLE.}

A. $\mathbf{1}^{1-20}$. Introduction.

1. 2 Greeting.

3-20 Appeal to Timothy to have courage to rebuke the false teachers:

1-11 (a) because their teaching does not promote the central spiritual purpose of the true Gospel committed to the writer himself. 
12-17 (b) because he himself can tell of power for ministry given to himself though the chief of sinners.

18:20 $(c)$ because of the prophecies about 'T'imothy's own ministry.

B. $2^{1}-6^{2}$. General Regulations:

$2^{1}-3^{13}(a)$ fir the Church.

$2^{1-7}$ (i) the scope of public prayers.

8-15 (ii) the conduct of men and women at public worship.

$3^{2-13}$ (iii) the character of ninisters: the bishop $\left({ }^{1-7}\right)$; deacons $\left({ }^{8-10}\right)$; deaconesses $\left({ }^{11}\right)$; deacons as aspirants to higher office (12. 13).

$3^{14 \cdot 16}$ Central doclrine. The Person of Christ the source of true religion.

$4^{1-5}$ Transition to the following regulations. I)anger of the teaching of a false asceticism.

$4^{6}-6^{2}$ (b) for Timothy himself.

$4^{\text {fi-16 }}$ (i) his own life and teaching.

$5^{1}-6^{2}$ (ii) his treatment of others; the old and young $\left(5^{\text {l. } 2}\right)$; widows $\left({ }^{3-16}\right)$; discipline over presbyters $\left({ }^{17-25}\right)$; slaves $\left(6^{1.2}\right)$.

C. $6^{3-21}$. Conclusion. Contrast between the false and the true teacher.

3-10 The false teacher misled by the hope of gain.

11-16 Appeal to Timothy to be a true man of God and fight the good fight.

11-13 Based on Timothy's past confession.

14-16 " "the example of Christ Jesus and the though! of $\mathrm{His}$ return to jucige.

17.19 The proper teaching to be given to the rich.

20. 21a Final appeal to 'Timothy.

21b Greeting.

\section{The Greeting.}

i. 1-2. I Paul, writing with all the authority of an Apostle of Christ Jesus, and in obedience to the direct commandment of God who has saved us from our sins, and of Jevus Christ, who is the object of our hope, send this letter to you Timathy, with all the conlidence which a father feels in a true son in the laith; and I ask God, the Father of us all, and Christ Jesus our Lord, to give you grace for your work, to aid you in your difficulties, and give you peace at heart. 
The greeting is formal and elaborate; it is partly personal to

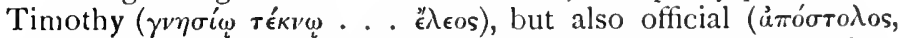
$\kappa \alpha \tau^{\prime} \dot{\epsilon} \pi\left(\tau a \gamma \eta^{\prime}\right)$, perhaps because the letter is meant to be read tc others (cf. $\left.\mu \in \theta^{\prime} \dot{v} \mu \hat{\omega} v, 6^{20}\right)$, and to be treated as an authoritative guidance for the Church or Churches to which Timothy has to communicate its regulations; it is to strengthen Timothy's hands against false teachers; cf. $\mathrm{I}^{11} 2^{7}$.

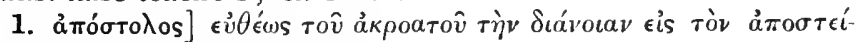
$\lambda \alpha \nu \tau \alpha \pi \alpha \rho \alpha \pi \epsilon ́ \mu \pi \epsilon \iota$ (Chrys.).

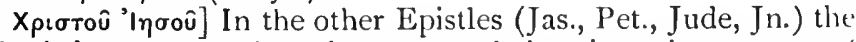
order is 'I $\eta \sigma . \mathrm{X} \rho$., perhaps because to their writers the memory of the earthly life had been the first thing; in St. Paul the order is generally $\mathrm{X}_{\rho}{ }^{\text {. '} I} \eta \sigma$. , perhaps because the knowledge of the Heavenly Messiah came before that of the earthly life; but there is no uniformity in him, though when he refers to facts of the earthly life the order is often ' $\mathrm{I} \eta \sigma . \mathrm{X} p .6^{3}$, II $2^{8}$, I Co $2^{2} 3^{11}{ }^{11} 5^{57}, 2$ Co $8^{9}$.

For a full examination of the usage, cf. I.C.C., Galatians, pp. 392 ff.

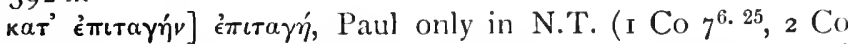

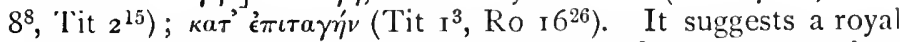
command which must be obeyed, cf. Esth $\mathrm{I}^{8}$, and was used of

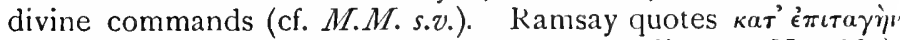
rov̂ Kupíov Tupávvov $\Delta$ ıós (Inscr. Le Bas IVaddington, No. 667). Here it refers primarily to the choice of Paul as an Apostlis: $\left(2^{7}\right.$, Acts $\left.22^{14}\right)$, though it may include the wider command of the King of all the ages (cf. $I^{17} 6^{15}$ ), revealing the message of salva-

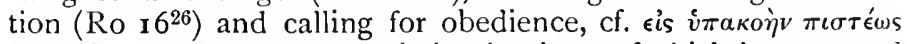
$\left(\operatorname{Ro~}^{5}\right)$. It gives the commission in virtue of which he acts, and the rule and standard of his work. Paul writes because necessity is laid upon him ( 1 Co $9^{16-18}$ ); he is anxious to be able to report

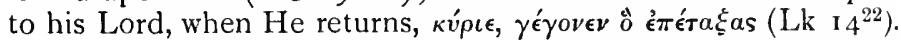

$\left.\theta \in o \hat{v} \sigma \omega r \hat{\eta} \rho \circ \hat{\eta}_{\mu} \hat{\omega} v\right]$ Possibly with an allusion to the heathen use of the title as applied to Zeus, Apollo, or Asculapius (Tit $2^{13}$ note); cf. Harnack, Exp. of Christianity, i. 2.2 ; but the phrase is Jewish, Dt $3^{25}$, Ps $24^{5}$, Lk I ${ }^{47}$, Jude ${ }^{25}$. By St. Paul it is applied to the Father in I Ti., to Christ only in 2 Ti. $\left\langle 1^{10}\right)$, to the Father and to Christ in Tit.: in the earlier Epistles only to Christ, Eph $5^{23}$, Phil $3^{20}$, but $\mathrm{cf}$. I Co $\mathrm{I}^{21}$. Here it anticipates the thoughts of $\mathrm{r}^{15} 2^{3.4 .15} 4^{10.16}$.

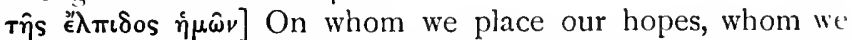

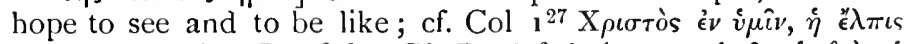

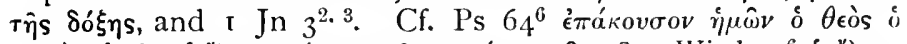

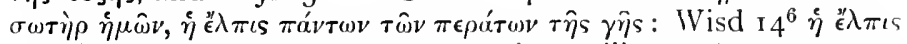
rov̀ кó $\mu$ ov, of Noah (Wohlenberg). Liv. xxviii. 39: "spem omnen

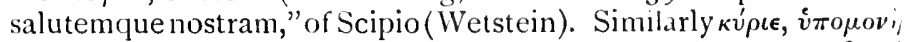
'I $\sigma \rho a \eta$, Jer ${ }^{2} 7^{13}$. Here the phrase has almost become a fixed 
titic, as it has become by the time of Ignatius (Trall. Inscr. and

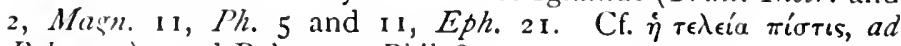
Polyc. ro): and Polycarp, Phil. 8.

2. T $\left.\iota \mu \circ \theta^{\prime} \omega\right]$ Cf. Introd., p. xxvi.

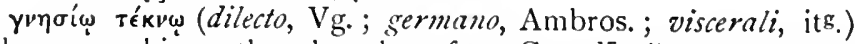
perhaps combines the thought of $\mathrm{I}$ Co $4^{17}$ "my true son whom I have begntten and to whom I have a right to alpeal,"

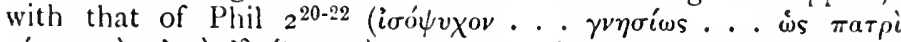

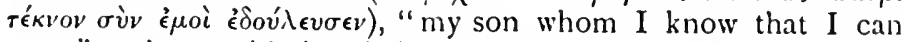
trust," perhaps with implied contrast to others who had failed him, inf. ${ }^{3-11} 6^{3-10}$. Dibelius compares the use of father and son for teacher and pupil in the Mysteries, quoting Poimandres

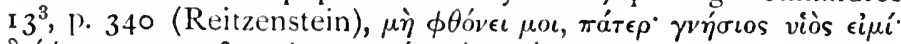

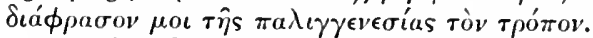

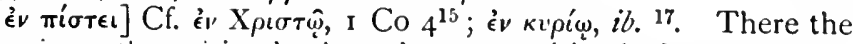
stress is on the spiritual sphere, here on spiritual character, faith

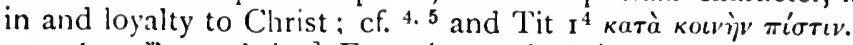

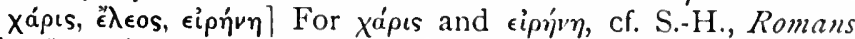

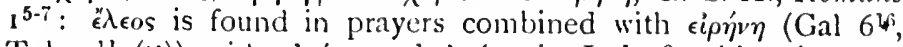

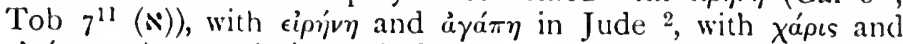
єip Ti. (not in Titus) may have reference to Timothy's difficulties

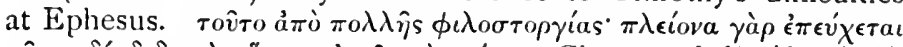

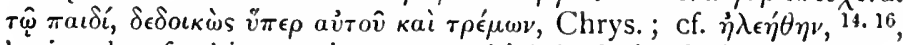
he invokes for his son the mercy which had aided himself.

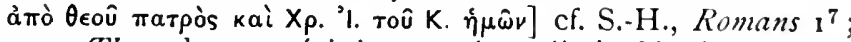

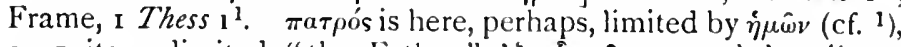

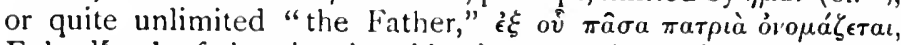
Eph $3^{15}$; the father invokes blessings on his spiritual son from the source of all fatherhood.

i. 3-20. Appeal to Timothy. Warn the false teachers at Ephesus not to waste their time on myths and genealogies and teachings about the law to the neglect of the true spiritual aim of the gospel. They entirely misunderstand the true purpose of the law, as seen in the light of the gospel. Its purpose was to control sin, but the gospel saves from sin; yes, it saved me the chief of simners, and I was allowed to be its preacher. Do you then, as my true child, hand on this charge, and be warned by the fate of Hymenæus and Alexander.

Note.-The key-words of the section are $\pi i \sigma \tau \iota s$ with its

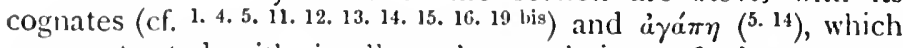
are contrasted with intellectual speculation: cf. the contrast between $\gamma^{2} \hat{\omega} \sigma \iota s$ and $\dot{a} \gamma a ́ \pi \eta$ in I Co 8 , between speaking with tongues and prophesying in I Co 14. 
3-11. Paraphrase. I wrote to press on you the purpose with which I urged you to stay in Ephesus when I had to leave for Macedonia. It is that you should strictly charge certain teachers there-I need not mention their names-not to pride themselves on being teachers of novelties, or to waste their time on untrustworthy legends and questions of genealogies which are unending, for they only supply them with abstruse investigations, and do not help them to do their work as God's stewards, whose one aim is to produce faith. The whole purpose of the charge which Christ has given us, His stewards, is to produce a true spirit of love, springing out of simplicity of aim, of a clear conscience, and a sincere faith. But some of these teachers have wholly failed in these qualities, and turned out of the narrow path into worthless discussions: they claim to be Christian rabbis, but they do not understand their own assertions, nor the meaning of the subjects on which they are so positive. But we know that the law is of high value, if a teacher enforces its right purpose, if he realizes that law is never enacted to control one who is already acting rightly, but it is to control the wilful and restless, those who violate their duty to God and their neighbour in any way that is inconsistent with the sound teaching of Christ. This is the position of the law in the light of the good news that the blessed God has now communicated His glory to men and enabled them to obey. It is this good news with which I was entrusted, I on whose behalf you have to speak.

Note.-With the whole section cf. Acts $20^{30}$, and inf. $6^{3-10}$ : here, the stress is laid on the character of the teaching; there, on the character of the teachers.

3. For the historical position, cf. p. xvii. On the duty of the Bishop to check his clergy from useless discussions, cf. Chrys., de Sacerd., $\$ \$ 409-12$.

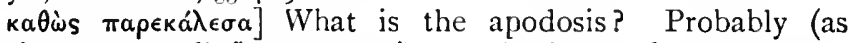

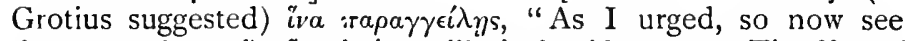
that you charge"; iva being elliptical, vid. note on Tit $3^{13}$. If this is not so, then the sentence is an anacoluthon, cf. Ro $5^{12}$; such anacolutha are common at the commencement of letters; cf. Ignatius, Rom. I, Eph. I, Sm. I ; Pap. Oxyr. x. I 299, quoted in M.M. s.v. katws. 'The reason is that the act of writing takes the place of an apodosis. "As I urged, so now I write." So on the stage the apodosis has often to be supplied from some movement on the part of the actor; cf. Soph. O.T. 325 . A similar movement explains $\mathrm{Mt} 26^{50}$.

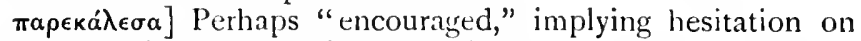
T.'s part (so Chrys., Theod.-Mops.), but more probably "urged." cf. $2^{1}$, Philem ${ }^{9}$. 
mporpeiva, (cf. $5^{5}$, not in the earlier lipistles, but cf. Acts $\left.13^{13}\right)$, slightly stronger than $\mu \epsilon^{\prime} \epsilon \iota v$, "stay on."

rıoi] 'They have not reached the point of shipwreck of faith, and have not had to be dealt with judicially like Hymenæus and Alexander $\left({ }^{20}\right)$; so he tactfully mentions no names; cf. 6.19 $5^{15.24} 6^{10.21}$, and compare $2 \operatorname{Co} 3^{1} 10^{2}$.

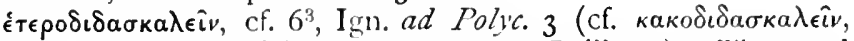

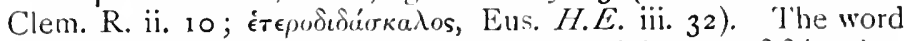

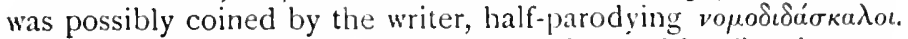
They pride themselves on being "teachers of law"; they are really only teachers of novelties, of things alien to the true

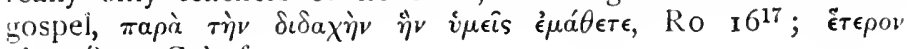

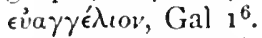

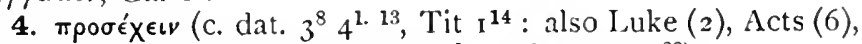
Ileb (2), not in the earlier letters; but cf. Acts 2028).

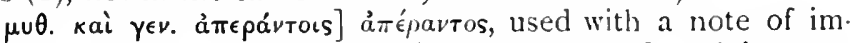

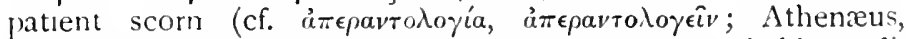
Strabo ap. Wetstein), is the emphatic word, and probably qualifies both $\mu v \theta$. and $\gamma \in \nu$. Cf. the similar protest in Epict. iii. 24 ,

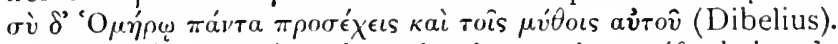

$\mu v \theta$. kai $\gamma \in \nu$. to be taken closely together, $\mu \varepsilon^{\prime} \theta$ o being defined by $\gamma_{\epsilon} \epsilon a \lambda o \gamma^{\prime} \alpha \iota$, legendary stories about genealogies; but $\gamma \in v \epsilon \alpha-$

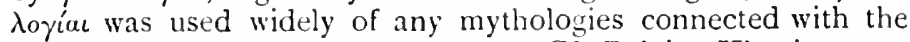
history of early founders of states. Cf. Polyb. Hist. ix. 1. 4,

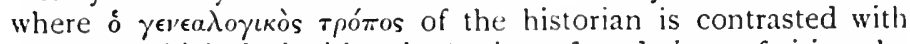
the parts which deal with colonizations, foundations of cities, the policy of nations, and is said to be specially attractive to the

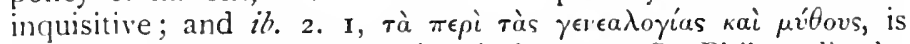
contrasted with these more historical parts. So Philo calls the

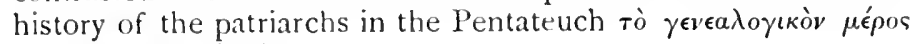
(de V. Mosis, ii. 8).

There may be implied here a contrast with the short, clear historical life and teaching of the Lord, "the mystery of godli-

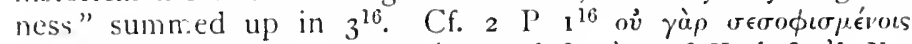

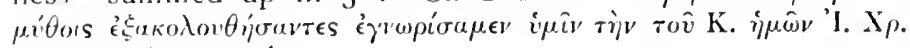

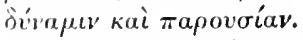

The exact reference of the words is uncertain.

(i) Probably they refer to something Jewish; and if so, to legencls and stories centring round the pedigree of the patriarchs and O.'P. history which were handed down in tradition, the Rabbinical Haggada, and which are prominent in Jewish $A_{\text {poca- }}$ lypeses (so cf. Hort, Judaistic Christiunit;', p. I 35), and were used (1) support the institutions of the Jewish law. The Book of Jubilees, "an attempt to rewrite prinitive history from the

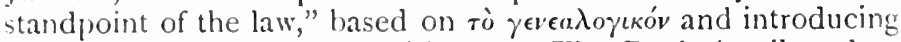
many legends about evil spirits, or "The Book (attributed tc 
Philo) concerning Biblical Antiquities," a legendary chronicle of O.T. history from Adam to Saul, dating from the ist century A.D. (ed. M. R. James, S.P.C.K., I9I7), would be the best illustrations of this. Cf. also Justin M. Dial. c. Tr. c. I I 2 ; Irenæus, i. 3o, for similar profitless discussions. This Jewish reference is made probable (i) by the fact that these teachers claimed to be

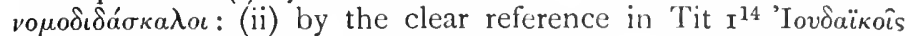

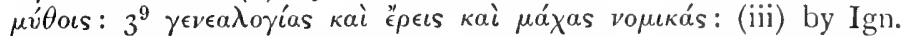
ad Magn. c. 8 (possibly an allusion to this place), where

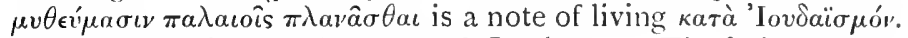
(iv) The allusion to Jannes and Jambres, $2 \mathrm{Ti} 3^{8}$, is perhaps drawn from such legendary Haggada.

This reference is supported by Chrys., Pelagius, Thdt. $\tau \dot{\eta} \nu$

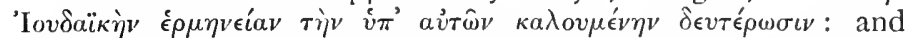
Ambrosiaster, "de fabulis quas narrare consueti sunt Judæi de generatione suarum originum." F. H. Colson ( $J$. Th. St. xix. 265-71) thinks that the reference is not to a Pharisaic Judaism, but to a "somewhat conceited pseudo-Hellenic Judaism," which treated the O.T. as the "grammatici" and "rhetores" treated Homer in literary circles; and he quotes a similar criticism of such points by Suetonius, Tiberius, c. 70, "Maxime curavit notitiam historiæ fabularis, usque ad ineptias atque derisum," quoted with other reff. by Mayor on Juv. 7. 234 .

(ii) But, possibly, to the genealogies of the æons, which in Cnostic teaching separated the supreme God from the material world, cf. $4^{1 \cdot 4}$. Irenæus directly applied these words to the teaching of Valentinus ( $a d v$. Har. praf. i.), and so did Tertullian (Prescr. 7 and 33); but neither states that our writer was referring to them, for Irenæus applies Mt $7^{15}$ and Tertullian $\mathrm{Col} 2^{8}$, Gal $4^{3} 5^{2}$ to the same heretics; and Tert. (adv. Valent. 3) supposes St. Paul to anticipate these teachers, and to meet the germs of their teaching ("his jam nunc pullulantibus seminibus hæreticis damnare prævenit"); cf. Introd. p. xvii.

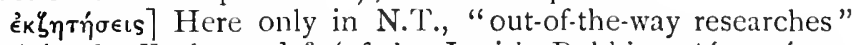

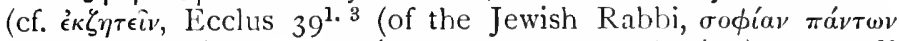

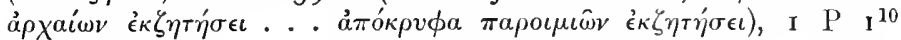
and "eruere"). For the distinction from $\zeta \eta \tau \eta \mu \alpha \tau a$, cf. Acts I $5^{2}$

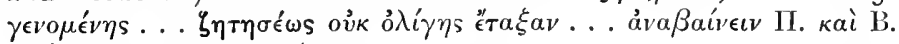

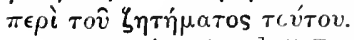

oikovopiav $\theta \epsilon o \hat{u}$ ] "God's stewardship," i.e. they do not help them to carry out the stewardship entrusted to them by God; cf.

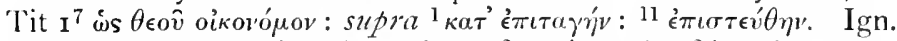

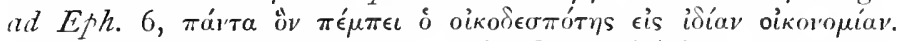
The metaphor is a favourite one with St. Paul (cf. esp. I Co $9^{17}$ ) and St. Luke: elsewhere only in $\mathrm{I} \mathrm{P} 44^{10}$. This is ultimately "God's own method," His "scheme of salvation" (cf. Eph ${ }_{\mathrm{I}}^{10}$, 
Ign. Eph. 1 8. 20 (ubi v. Lightfoot), Clem. Alex. Strom. i. 24: oikovo.

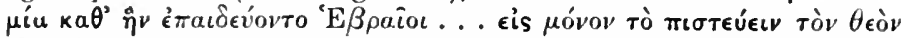
ival (quoted with other interesting illustrations in Tatiani, Or., ed. Schwarz, Texte und Unters. i. 4. I, pp. 86-90); but the analogy of Tit $\mathbf{r}^{\tilde{7}}$ shows that this is not the primary thought here, and is almost conclusive against the reading of the Western text, oiko$\delta o \mu \eta^{\prime}$, for which cf. $3^{15}$, 1 Co $3^{9}$, and supra, p. xxxvi.

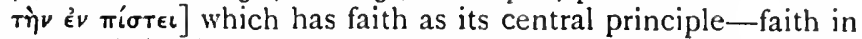
the steward (cf. ${ }^{1}$ ) and faith in those whom he teaches (cf. ${ }^{5}$ ); faith, not abstruse questionings (cf. ${ }^{4}$ ); faith, not stress on law (7-11); cf. Col 2, Gal 3.

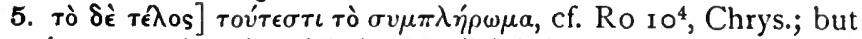

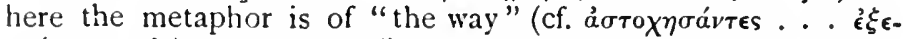

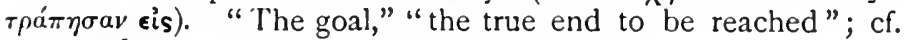

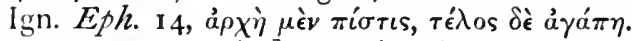

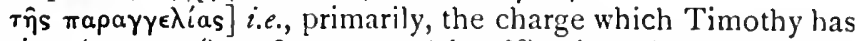

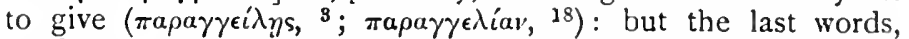
oikod. $\theta \epsilon o \hat{v} \tau \hat{\eta} \nu$ év $\pi i \sigma \tau \epsilon \iota$, have carried the mind on to the whole scheme of salvation, and perhaps extend the meaning more widely - the end of all Christian moral preaching, the whole moral charge which is given to God's stewards; cf. $\dot{\eta} \delta i \delta a \sigma \kappa \alpha \lambda i^{\prime} a, 6^{1}: \dot{\eta}$

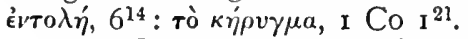

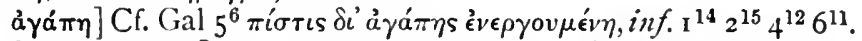

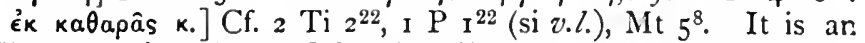
O.T. conception, Gen $20^{5.6}$, Job I I ${ }^{13} 33^{3}$, Ps $23^{4} 50^{12}$.

$\sigma u v \epsilon \_\delta \dot{\eta} \sigma \epsilon \omega s$ ả $\gamma$.] I ${ }^{19}$, I $\mathrm{P} 3^{16.21} ; \kappa a \lambda \dot{\eta}^{\prime}$, Heb I $3^{18}$; contrast $\sigma v v \epsilon \epsilon \delta . \pi \circ v \eta \rho$ á, Heb $10^{22}$. For the history of the word, which is of Greek philosophic origin, cf. S.-H. on Romans $2^{15}$; Bonhoffer, Epiktet und das NT, p. I 56 .

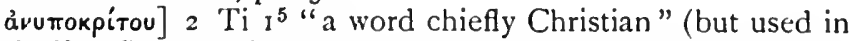
Wisd $\left.5^{19} 18^{6}\right)$, "as might be expected from Our Lord's warnings

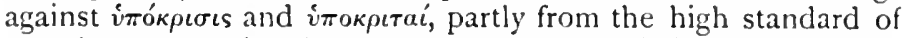
veracity set up by the Apostles; cf. Jas $3^{17}$ ( $\left.\sigma o \phi i ́ a\right)$, Ro $12^{9}$,

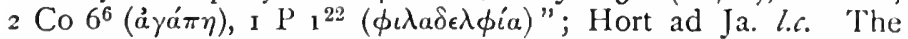
words are in an ascending scale, simplicity of aim, which is

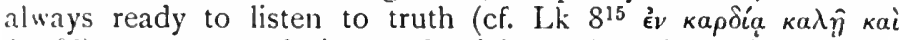
$\dot{a} \gamma u \theta \hat{\eta})$, a constant desire to do right, and a faith which accepts Christ as its guide with sincerity and consistency (cf. Gal $2^{13}$ ), resulting in love for God and man.

All these qualities can be re-created in the penitent sinner; cf. P's $50^{12}$, Heb $10^{22} 3^{12}$.

6. $\dot{\omega} v]$ Failure in these moral qualities loses sight of the true goal ; cf. I ${ }^{19}$.

åorox.] $6^{21}, 2^{2} \mathrm{Ti}^{18}$ (only in N.T.), Ecclus $7^{19} 8^{9}$, and common in Polybius and Plutarch, "failing to strike," or perhaps, rather more definitely, "taking no pains to aim at the right 
path" ; cf. the description of their character in 63-5, Ecclus $8^{9}$

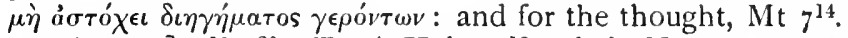

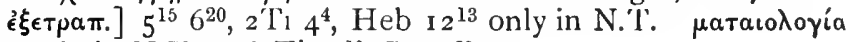
here only in N.T.; cf. Tit $\mathrm{I}^{10}$, Ro $\mathrm{I}^{21}$.

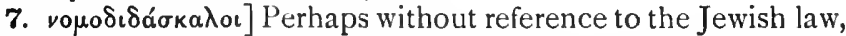
half-ironical, "claiming to be professors of moral philosophy";

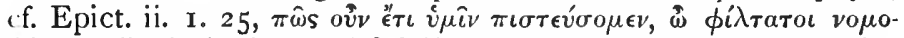
$\theta$ '́taı (Dibelius); but vv. ${ }^{4.8 .9 .10}$ make a reference to the Jewish law more probable.

Tivwv] The interrogative is probably used for the relative for the sake of variety alone, as in late Greek they tended to become interchangeable; cf. Moulton, N.T. Greek, p. 93 ; Blass, p. I 75 .

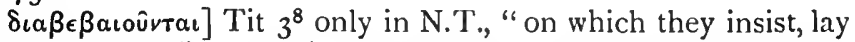
so much stress." Hort (W.H. App., pp. 167 and I 7 I) suggests

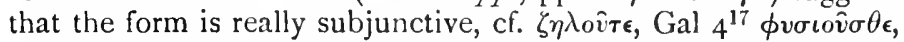
I Co $4^{6}$, "nor on what points they ought to insist"; cf. Ro $8^{26}$

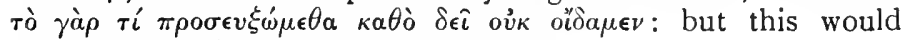
probably have been stated more clearly.

8. o" $\delta \alpha \mu \epsilon \nu]$ "We Christians," with, perhaps, a conscious refer-

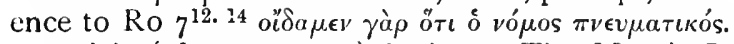

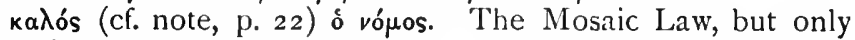
as the instance used by these teachers of what is true of all law, vómos 9 .

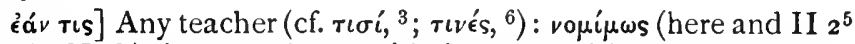
only in N.T.), in accordance with its true spirit, "as a law," not "as a Gospel." "Si quis sciat quibus, quare, et quamdiu habenda sit data," Pelag. Law with its penalties is needed to control sinners, but when once the true love of God is created in a man's heart, there is no longer need to appeal to its sanctions; Love fulfils it: the true Christian is "non sub lege sed cum lege" (Aug. on Jn I, Tr. 3), he is " amicus legis" (Ambrosiaster on Ro $\left.2^{12}\right)$, and law is put on a firmer basis, not as a penalizing force, but as the guidance of a loving God; cf. Ro $3^{31} 7^{14} 8^{4}$ ${ } 3^{8-10}, \mathrm{Gal} 5^{23}$. "When at last love suffuses all the mind-love of God and His Laws, and love for our neighbour as made in His image and the chief mirror of His goodness, then indeed the yoke becomes easy and the burden light," Inge, Personal Idealism, p. 16.

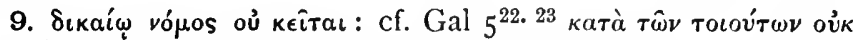

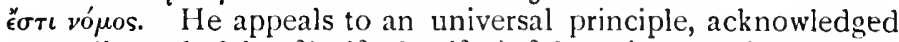

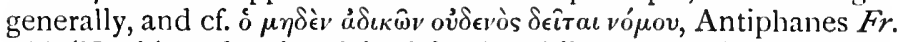

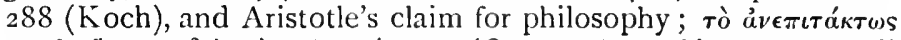

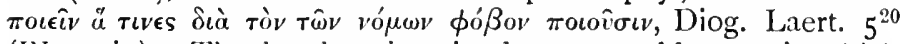
(Wetstein). The heathen imagined a past golden age in which law was not needed (Tac. $A n n$. iii. 26 ; Ovid, $M$. i. 90 ), and the 
Christian Fathers attributed the same to the patriarchal period; cf. Ambrosiaster, ad loc., "Custodientes legem naturalem, quam si humanum genus ducem habuisset, lex in litteris per Moysem data non esset"; and Iren. iv. 16. 3, quoting this verse, "lex non posita est justis': justi autem patres virtutem decalogi conscriptam habentes in cordibus et animabus suis . . . non fuit necesse admoneri eos correptoriis literis." Ambrose, de Off. iii. 5. 3 I, "Justus legem habet mentis suæ et æquitatis et justitıæ suæ normam, ideoque non terrore pœnæ revocatur a culpa sed honestatis regula" (Wohlenberg).

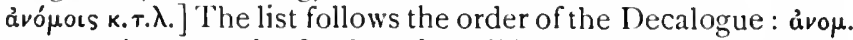
кai åvumor., the general refusal to obey all law: ả $\sigma \in \beta$. кai å $\mu$. (cf. I P $4^{18}$, Jude ${ }^{15}$ ) the general refusal to obey the law of God: arvor. kai $\beta \epsilon \beta \eta^{\prime} \lambda$., the more detailed opposition to the law of God: $\pi a r \rho o \lambda . \mu \eta \tau \rho \circ \lambda$. the 5 th, a $v \delta \rho \circ \phi$. the 6th Commandinent, cf. Ex $20^{15}$,

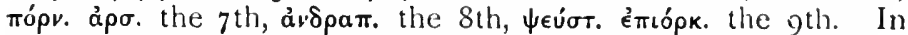
each case extreme forms of the sin are chosen to emphasize the strength of the evil in the heathen world and the real need of law for those who have not heard of the gospel: cf. Ro I 21-32. ['lato, Phred., pp. I I 3, I I4; Verg. EEn. vi. 608 sqq.

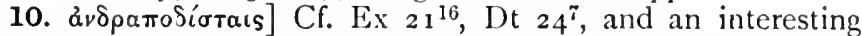
chapter in Philo, de Spec. Legg. iv. 4, which condemns ả $\nu \delta \rho \pi 0$.

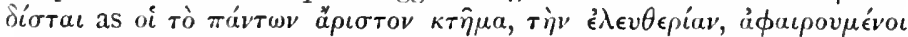

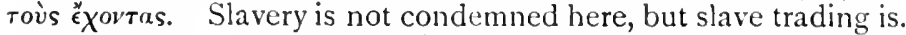

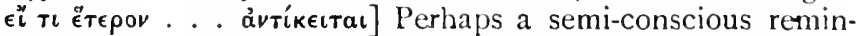

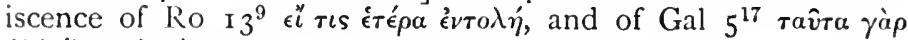

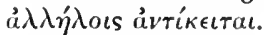

Tท̂ ưıaเvoú but as these sins have just been treated as sins controlled by the Mosaic Law, the gospel is thought of as absorbing in itself the Law of Moses and, we may add, the natural law written in the hearts of the heathen, which itself often, as embodied in legislation, condemned many of these vices ; cf. $5^{8}$, ICo $5^{1}$; so Pelag. "legem evangeliis concordare demonstrat," and Ambrosiaster, quoted above.

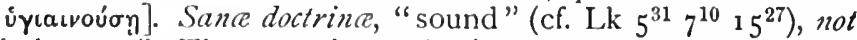
"wholesome." There may be an a!lusion to the diseases of the soul

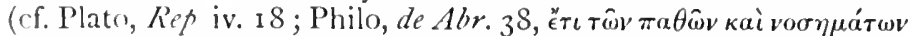

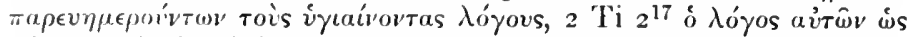

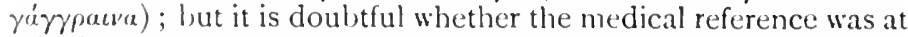
this time more conscious than in our word "sound": cf. Prov $24^{76}$

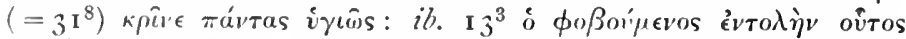

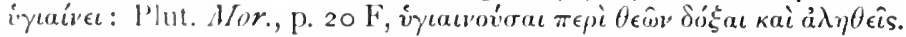
The metaphor is common in and conlined to the Pastoral Epistles in N.T. $6^{3},{ }_{2} \mathrm{Ti}^{13} 4^{3}$, 'Tit $1^{9.13} 2^{1.2 .8}$ : it is of a piece with the stress on an ordered regulated life, and is found in Stoic writers: íyı̀̀s hóyos, Marc. Aur. viii. 30. 


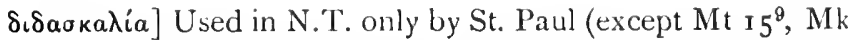
$7^{7}$ in quotation from Is $\left.29^{13}\right)$, 5 times in Past. Epp., 4 elsewhere. It varies elsewhere between the sense of "active teaching" (cf. 4" ${ }^{13-16} 5^{17}, 2$ T' $3^{16}$, Tit $2^{7}$, Ro $12^{7}{ }^{1} 5^{4}, \mathrm{Col} 2^{22}$ ) and "the body of doctrine" $\left(4^{6}{ }^{61.3}, 2 \mathrm{Ti}^{10}(\right.$ ? $), 4^{3}$, Tit $\mathrm{I}^{9} 2^{1 .}{ }^{10}$, Epl $\left.4^{14}\right)$ : here the latter is probably right, as it implies a definite standard; but the

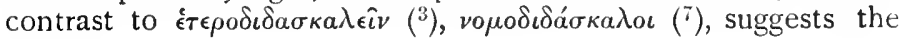
former.

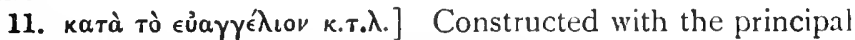
sentence oï $\delta \mu \mu v$... . $\chi \rho \hat{\eta} \tau a \iota$ : cf. Ro $2^{16}$.

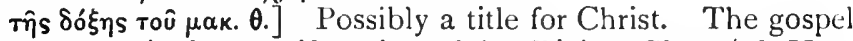
of $\mathrm{Him}$ who is the manifestation of the Divine Glory (cf. Hort on Jas $2^{1}$ and Tit $2^{13}$ note); but the context suggests rather the glory of God as manifested in man, of which all sinners fall short (Ro $3^{23}$ ), but whıch gives liberty to the children of God (Ro $8^{21}$ ), which is the note of a ministry of righteousness and of the Spirit, and into which we are gradually transformed, 2 Co $3^{7 \cdot 18} 4^{4 \cdot 6}$ I $\mathrm{P}_{4}{ }^{14}$. It is thought of here as a present glory, though its complete realization will come with the Retuming Christ, of. $6^{15.16}$.

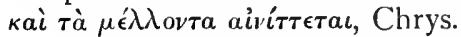

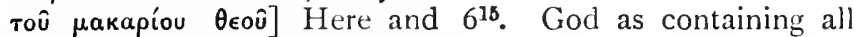
happiness in Himself and bestowing it on men. "Beatus beat" (Bengel) ; cf. Is $65^{19}$ "I will rejoice in Jerusalem, and joy in my people." The exact title is not found elsewhere, but "the happy gods," $\theta \epsilon o \grave{i} \mu \dot{\alpha} \kappa \alpha \rho \epsilon s$, is frequent from Homer's time; and the idea of God as independent of men, and containing all happiness in

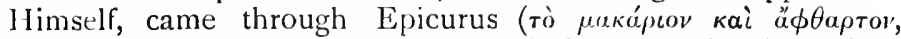

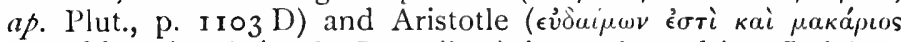
. . . Si aúròv aúrós, de Rep. vii. I) into Alexandrine Judaism,

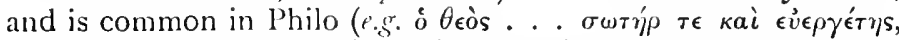

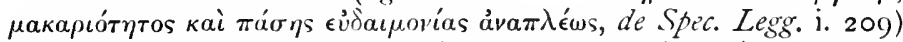

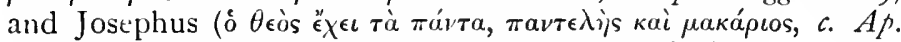
ii. 22). See other instances in Wetstein and Dibelius.

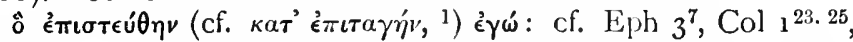
Tit $I^{3}$. I, your father, whom you have to represent; I, the found $\mathbf{r}$ of the church, who have authority to enforce against false teachers (cf. I Co $4^{15}$ év $_{\text {è } \rho} \mathrm{X} \rho$. 'I $\left.\epsilon^{\prime} \gamma^{\prime} v^{\prime} \eta \sigma \alpha \dot{v} \mu \hat{\alpha} s\right)$; I, who know the power of the gospel to rescue from sin.

12-17. Paraphrase. Yes, it was entrusted to me; but when I say me, I must stop to thank Him who gave me strength for the task, Christ Jesus our Lord, for He deemed that He could trust me; for His own purpose He chose me for service,-me who before had blasphemed His truth and persecuted and harried $\mathrm{His}$ followers. But mercy was shown to me, because $I$ did it in 
blindness while still unbelieving; but the grace of our Lord overfowed its channel and flooded my heart with faith and love, that perfect love which is known only in Christ Jesus. Faithful, undeed, is that saying, and worthy of whole-hearted acceptance:

\section{"Christ Jesus stooped this world within} Sinners to rescue from their sin,"

sinners-of whom I am chief; yet for this very purpose was mercy shown to me, that in me first Jesus Christ might make clear that there are no limits to His long-suffering, and so make me the first sketch of all the myriads who are going to believe on Him and win life eternal. Now to Him who rules the ages, to the immortal, the invisible, the only God be honour and glory age after age. Amen.

This section is a personal digression, dominated by the

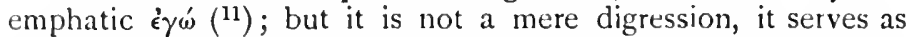

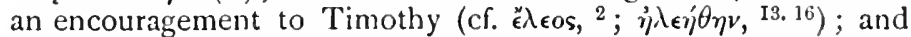
it illustrates the main purpose of the gospel, to save sinners and to produce love and faith; $\mathrm{cf} .2 \mathrm{Ti}^{12-14}$.

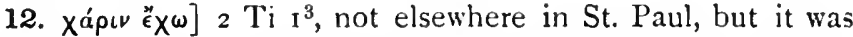

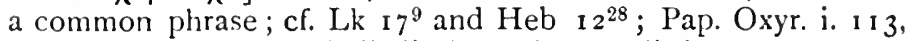

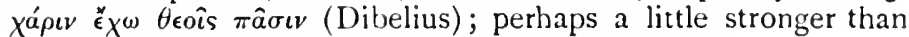

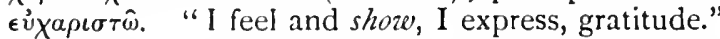

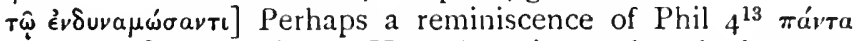

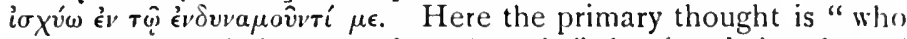
gave me strength for my task as Apostle," the time being that of

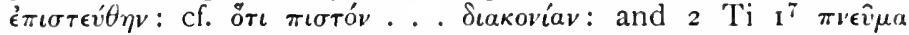

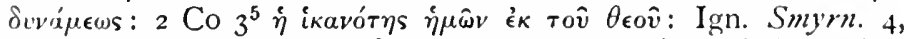

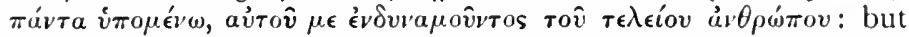
there lies behind this "the strength to conquer sin and obey the law" (cf. Ro $5^{6} 8^{3}$ ), and this thought emerges in 14-16, cf. 10-11.

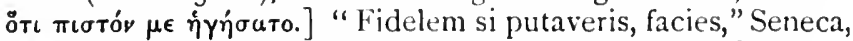

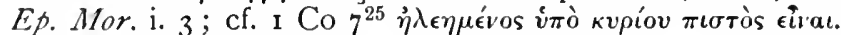

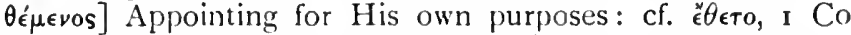

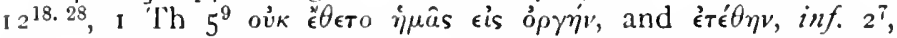
$2 \mathrm{Ti}_{1}{ }^{11}, \mathrm{P} \mathrm{P}_{2}{ }^{8}$ (utiv $v$. Hort). There is perhaps a reminiscence

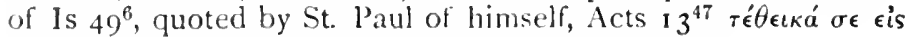

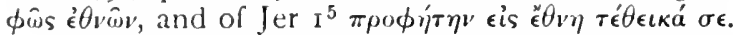

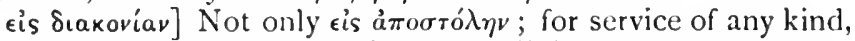
cf. 1 Co $16^{15}, 2 \mathrm{Ti}^{11}$, Heb $1^{14}$, Acts $1_{1}{ }^{29}$ (when Paul was used for much humbler service), $20^{24}$ in Paul's address to the elders of Ephesus; but, above all, for the ministry of reconciliation, 2 Co $5^{18}$.

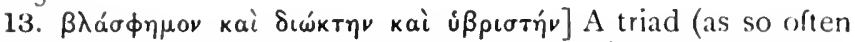
in St. Paul) with perhaps an ascending scale rising from words to 
acts of authorized persecution and of illegal violence; $c f$. Ps $I^{1}$. Bengel would treat them as sins against God, against others, and against himself (insulting his own Saviour), all failures in love; but though $\beta \lambda \alpha$ á $\phi \eta \mu \nu v$ may include blaspheny against God, the other distinction is fanciful; and the main thought of each word is of attacks on the Church; $\mathrm{cf}$. Gal I ${ }^{13.23}$, Phil $3^{6}$, Acts $22^{4}$ 26-11. $^{9-1}$.

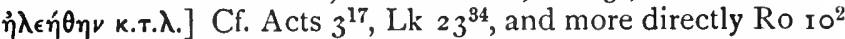

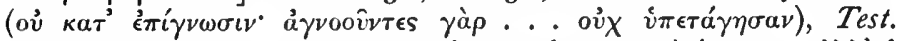
XII. Patr., Jud. I9, of which this may be a ren iniscence, $\alpha^{3} \lambda \lambda^{2} \dot{o}$

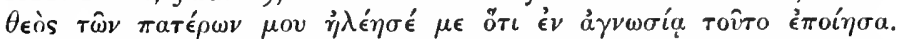

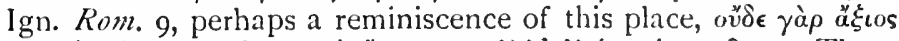

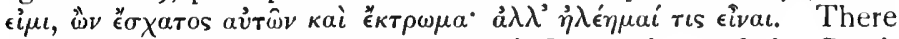
is therefore no reason to assume the influence here of the Greek conception that $\sin$ is the result of ignorance.

14. $\left.\varepsilon \pi \epsilon \rho \epsilon \pi \lambda \epsilon v^{\prime} \alpha \sigma \epsilon\right]$ Here only in N.T., but found in Ps.-Sol $5^{19}$;

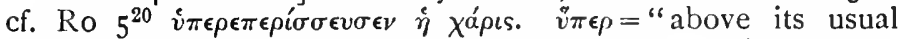
measure," rather than "rising higher than my sin." This v. was the origin of the title of Bunyan's autobiography, Grace Abounding.

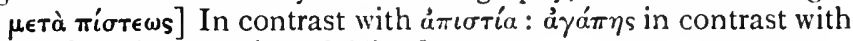
$\beta \lambda$. каi $\delta$. каi $i \beta \rho \iota \sigma \tau \dot{\eta} \nu$ : cf. 'Tit $3^{3}$.

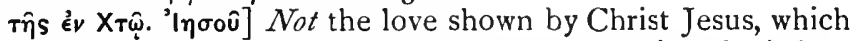
is already implied in $\dot{\eta} x a ́ p t s, b u t$ the true love which Christians feel, cf. ${ }^{5}$ supra, and which is only felt in union with Christ,

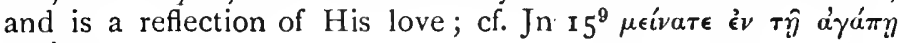
$\tau \hat{\eta} \epsilon \mu \hat{\eta}$.

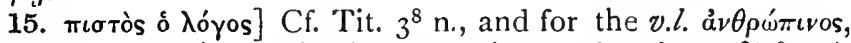
cf. Introd. p. xxxvi. Probably a quotation, as the phrase $\dot{\eta} \lambda \theta \epsilon \nu \in \hat{i}$

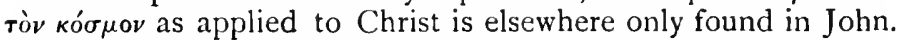
The whole phrase implies a knowledge of Synoptic and Johannine language ( $\mathrm{cf}$. Lk $5^{32}, \mathrm{Jn} \mathbf{1}^{47}$ ), and is a witness to their essential unity, but does not imply direct quotation from either.

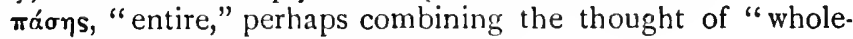
hearted," cf. ${ }^{16}$, and "universal," cf. $2^{4}$.

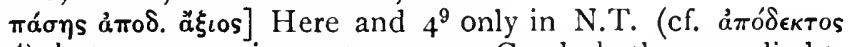
$2^{3} 5^{4}$ ), but common in contemporary Greek, both as applied to persons-cf. Dittenberger, Syll. 246, fronı Sestos, c. I 30-I 20 B.C.,

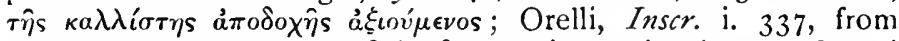

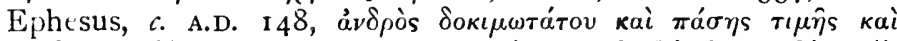
$\dot{a} \pi \circ \delta o \chi \hat{\eta} s \dot{\alpha} \xi i o v$ and to things or sayings; cf. Diodorus Sic. xii.

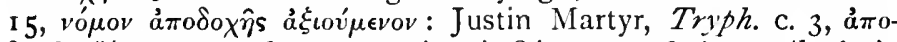

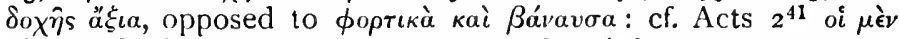

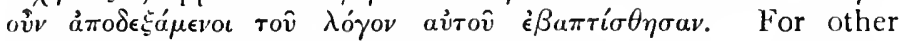
instances, see Field, Otium Norvic, ad loc., and Wetstein. Its meaning varies between mere "accemance" and stronger

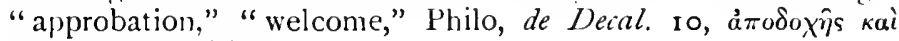
$\tau \iota \mu \hat{\eta}$ s $\mu \epsilon \tau \alpha \lambda \alpha \mu \beta u ́ v \epsilon \iota \nu$. 


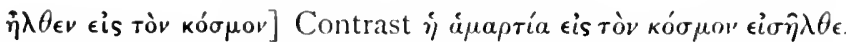
Ro $5^{12}$ and ef. Jn $1^{9} 12^{46}{ }^{2} 6^{28}$. 'The analogy of $\mathrm{Jn} 6^{14}$, Ro $5^{12}$ shows that the idea of Divine pre-existence is not necessarily involved in it.

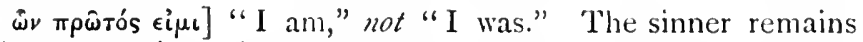
a sinner even if forgiven; the past is always there as a stimulus to deeper penitence and service. The sins for which he reproaches himself are not sins against the moral law (ef. Phil $3^{6}$ ), but sins against the truth and the light; sins which disqualified him from Apostleship Hence the longer he lives, the more he knows of the power of Christ and His truth, the severer becomes the self-reproach for having opposed it; cf. I Co $15^{9} \dot{\epsilon} \lambda a ́$ ícoros

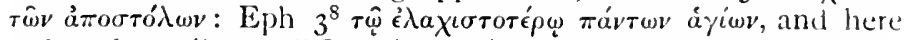
$\pi \rho \hat{\omega} \tau$ os $\dot{\alpha} \mu \alpha \rho \tau \hat{\omega} \lambda \omega \nu . " Q u o n i a m$ enim præ ceteris Sacramento se imbuit Salvatoris, propius ad cognoscendam magnificentiam ejus accedens, accusat se magis qui tantum boni tarde agnovit," Ambrosiaster. For similar self-condemnation, cf. Tert. de Pan. c. 4 and c. 12, with Glover's comment, Conflict of Religions, P. 3r3, and Mr. Keble's Letters of Spiritual Counsel, l'reface, pp. $\times x \times v-1$. Celsus used this verse to point his taunt against the character of the Apostles, Orig. c. Cels. i. 63; cf. Ep. liarn. v. 9. Moreover, by this time Paul had himself been evil-spoken of (Ro $3^{8}$, I Co $4^{13} 10^{30}, \mathrm{Ac}_{1} 3^{45}$ ), persecuted ( 1 Co $4^{12}, 2$ Co $4^{9}$, Ac $13^{50}$ ), insulted ( $\mathrm{T}$ Th $2^{2}, 2$ Co $12^{10}$ ), and so could more keenly enter into the feelings of those whom he had wronged.

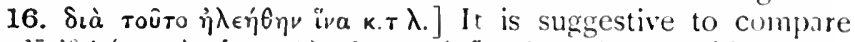

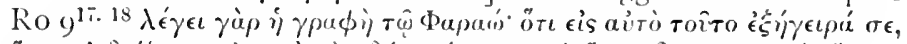

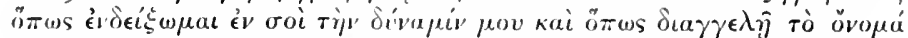

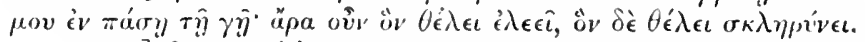

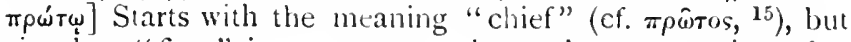
also implies "first" in contrast to those who are coming after $(\tau \hat{\omega} \nu \mu \epsilon \lambda \lambda o ́ v \tau \omega \nu)$.

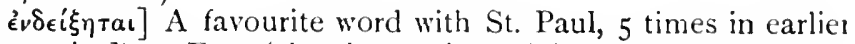
Epp., 4 in Past. Epp. (elsewhere 2 in Heb.). He only also uses $\tilde{\epsilon} v \delta \epsilon \iota \gamma \mu \alpha$ and $\epsilon^{*} \nu \delta \epsilon \iota \xi \iota s$.

'Inooûs Xpıotós] The change of order (contrast vv.1. 2. 12.14. 15) perhaps emphasizes the note of personal affection, and recalls the moment of conversion, and the words é $\gamma \dot{\omega} \epsilon i \mu \iota ' I \eta \sigma o \hat{v} s$ òv $\sigma \grave{v}$ $\delta \iota(\omega) \kappa \epsilon \iota s$, Acts $9^{5}$.

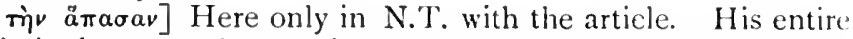
unlimited, ever-patient patience, not only converting, not only choo-ing me for service, but making me Apostle, and keeping me faithful.

úmorúrwoเv] Here and $2 \mathrm{Ti}^{13}{ }^{13}$ only in N.T.: an incomplete

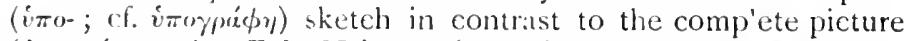

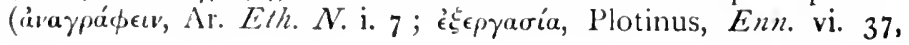


ap. Wetstein, who quotes other instances): the first sketch for a gallery of portraits; cf. $\sigma$ kiá, Heb $\mathrm{I}^{1}$. The substantive may be consciously active, "that He might draw a sketch," "ad informationem," Vulg.; "Cleformationem," $\Lambda \mathrm{m}$. : or of the result "to serve as a sketch," "ad exemplum," Ambrosiaster. The former is more common elsewhere: the latter suits 2 Ti $1^{13}$ better; of

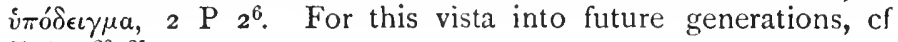
Eph $3^{20.21}$

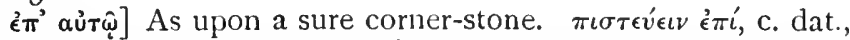
is only applied elsewhere to Christ in quotations from Is $28^{16}$ (Ro $9^{33} \mathrm{IO}^{11}, \mathrm{I} \mathrm{P}^{6}$ ), and that passage may be in the writer's mind here.

17. For similar doxologies, cf. Gal $\mathbf{1}^{5}$, Ro I I $^{36}{ }_{16} 6^{27}, \mathrm{Ph}_{4}{ }^{20}$, Eph $3^{21}$ inf. $6^{16}$.

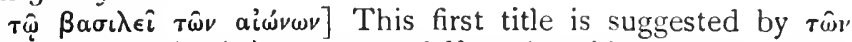

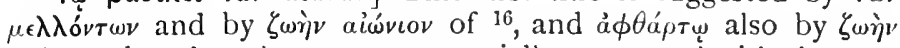
ai ívıov: but the others are not specially connected with the context, and the whole is probably a semi-quotation from some Jew-

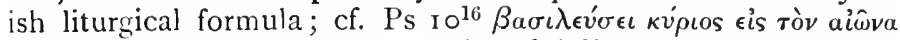

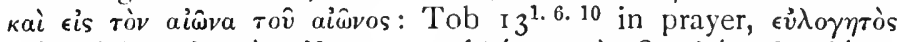

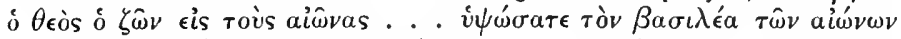

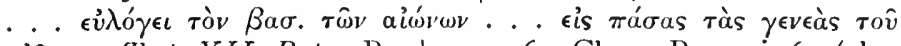
aîuvos: Test. XII. Patr., Reuben, c. 6 ; Clem. Rom i. 6r (also in a prayer), Liturg. Jacobi, Brightman, $E$. and $W$. Lit., p. 5 I.

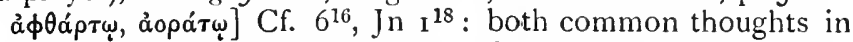
Greek philosophical conceptions of God, and in later Jewish speculations ; cf. Wisd I $2^{1}$; Philo, de Abr. 75 f.; Vita Mosis, ii. I 7 I ; Josephus, Bell. Jud. vii. 346 ; Epicurus ap. Diog. Laert. x.

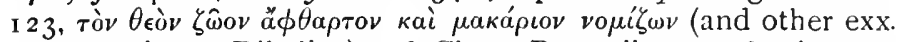
in Wetstein or Dibelius); cf. Clem. Rom. ii. $20, \tau \hat{\omega} \mu \hat{\nu} \nu \omega \Theta \epsilon \hat{\omega}$

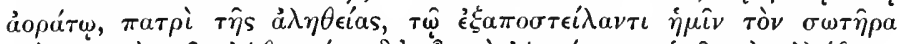

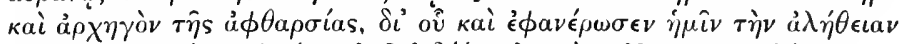

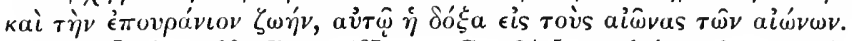

róvw] Cf. $6^{16}$, Ro $16^{27^{2}}$. I Co $8^{4.5}$ explains the emphasis on this.

18-20. Paraphrase. This charge, then, I now in my absence place in your care, my own son Timothy; recalling to mind the words of the Christian prophets which led me to choose you to help me in my work, that in the strength of these words you may carry on God's true campaign, holding fast yourself faith and a good conscience, for remember how some refused to listen to their conscience and so made shipwreck of their faith : of such are Hymenæus and Alexander on whom I formally passed sentence, that they may learn under discipline not to speak against the truth.

Compare the similar warning from the example of others in $2 \mathrm{Ti}_{1}{ }^{15}$. 
18. $\tau a u ́ \tau \eta v ~ \tau i ̀ v ~ \pi a p a \gamma \gamma \in \lambda i ́ a v]$ i.e. the charge of ${ }^{5}$ as expanded in 11 .

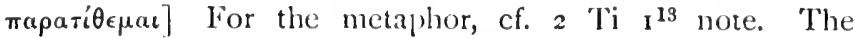
middle show's that he still feels his own responsibility : he will still have to give account for that which had been entrusted to him, "1. "That I may be faithful to my trust, I choose one whom I can trust," cf. 2 Ti $z^{2}$.

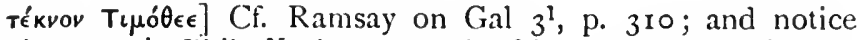
how here, as in Phil $4^{15}$, the personal address to another follows directly on an account of his own work and of Christ's power to aid him. Is there a play on Timothy's name, "You whose name commits you to giving honour to God"? cf. $\tau \hat{\omega} . . \theta \epsilon \hat{\omega}$ $\tau \iota \mu \eta^{\prime}{ }^{17}$.

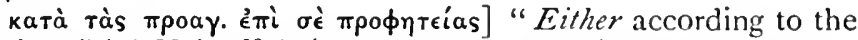

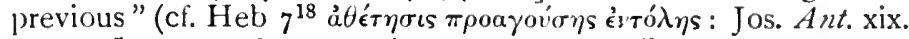

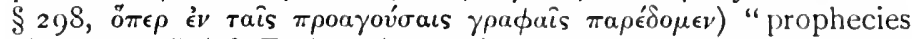

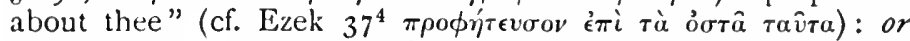
"according to the prophecies leading" (cf. $5^{24} \pi$ poó $\gamma$ ovora $\epsilon$ is

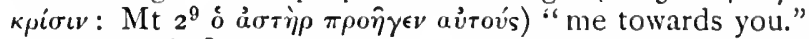

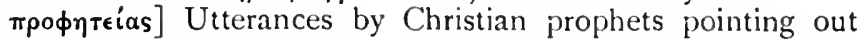
T.'s promise of useful work. The plural points to more than one such occasion, and may well include St. Paul's first choice of

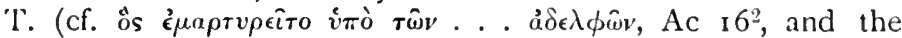
appeal to their first common work in $2 \mathrm{Tl}^{\mathrm{Il}}$ ), and his delegation of him for the special work at Ephesus; cf. $4^{14}, 2$ Ti $1^{6}$ (of 'Timothy himself), Ac $13^{1-3}$ (of St. Paul's delegation to new work),

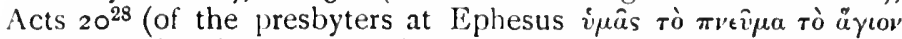

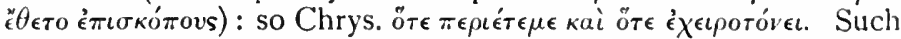
prophecies may have come from Silas, who himself was a prophet, Acts $15^{32}$.

iva oтpateún... oтpateíav] The metaphor is perhaps suggested here by $\tau \hat{\omega} \beta \alpha \sigma \iota \lambda \epsilon \hat{\imath} \tau \hat{\omega} v$ ai $\omega v \omega v$, the true campaign in

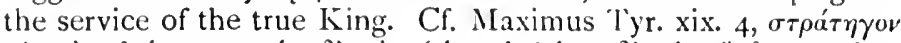

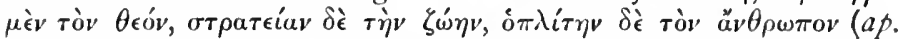
Wetstein). It was a common metaphor both in philosophical

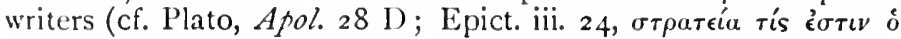

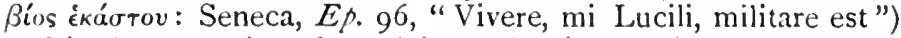
and in the mysteries, cf. Apuleius, Met. xi. I 5 , "da nomen sancta huic militix." "Enrol thyself in the sacred soldiery of Isis." 'These may have influenced the Christian use of it, but the thought here is more of an aggressive campaign against evil, and its use is

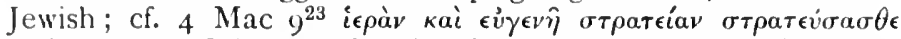
$\pi \epsilon \hat{\imath}$ tìs $\epsilon \dot{v} \sigma \epsilon \beta \epsilon \epsilon^{\prime} a s . ~ " O m n i s$ vita hominis militia (Jol) $7^{1}$ ) imprimis hominis Christiani (2 Co $10^{4}$ ) maxime vero pastoris evangelici ( 1 Co $9^{7}, 2$ Ti $2^{3.4}$, Phil $2^{25}$ ), "Grotius. For interesting illustrations cf. Wetstein and Dibelius, ad loc. 


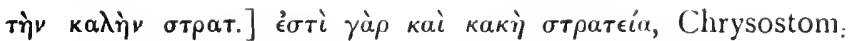
but the contrast is rather with service of earthly kings.

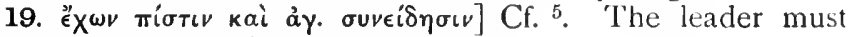
have the qualities he is going to enfurce.

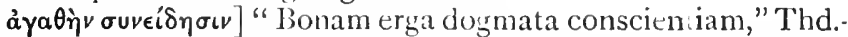
Mops. 'This may be included, but the thought is as wide as in 5 .

$\left.\ddot{\eta}^{\prime}\right]$ ] $i$ e. $\sigma v v \epsilon i \delta \eta \sigma \iota v, \mathrm{cf} .{ }^{6}$ note. The teacher who does not practise what he preaches will find his faith fail him.

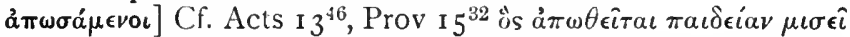

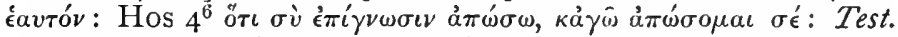

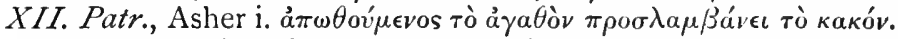
The word implies violent effort, a kicking against the pricks; cf. Bengel, "Invita recedit: semper dicit Noli me lædere"; cf. $\dot{\alpha} \pi \eta \lambda \gamma \eta \kappa o ́ \tau \epsilon \varsigma$, Eph $4{ }^{19}$.

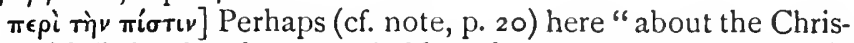
tian faith," i.e. they have not held to the central doctrines, cf. ${ }^{6}$;

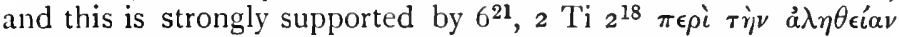
$\dot{\eta} \sigma \tau o ́ \chi \eta \sigma \alpha \nu$, and perhaps by $\mu \grave{\eta} \beta \lambda \alpha \sigma \phi \eta \mu \epsilon \hat{\imath}\left({ }^{20}\right)$; but the connexion

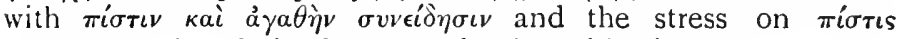
throughnut the whole chapter make the subjective meaning more probable.

Évauáyquav] For the metaphor, cf. Orelli on Hor. Od. i. I4; Lightioot on Ign. ad F'olyc. c. 2 ; Cebetis Tabula, vaváyovotv év

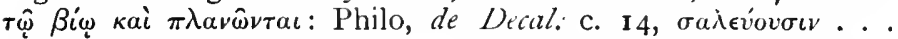

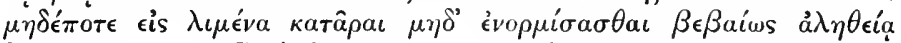
$\delta v \nu \alpha ́ \mu \epsilon v o c$. The Christian teacher must be good soldier and good sailor too.

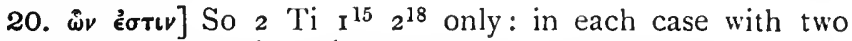
nominatives, perhaps implying some common action of the two.

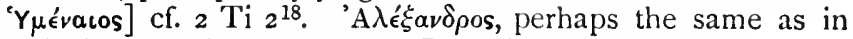
$2 \mathrm{Ti}_{4}{ }^{14}$, but not the same as the Jew Alexander, Ac $19^{33}$.

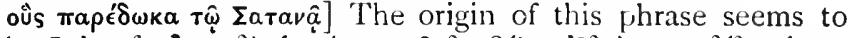

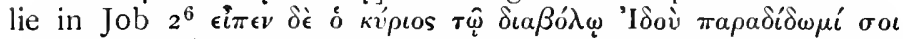

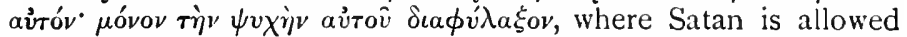
to inflict any bodily suffering short of death on Job to test the sincerity of his religion. Hence it seenıs to have become a formal phrase for passing sentence, perhaps in the Jewish synagogue, certainly in the Christian Church; and it is also possible that the use may have been influenced by, it is at least illustrated by, the contemporary Pagan "execration-tablets" by which a person who had been wronged handed over the wrong-doer to the gods below, who inflicted bodily suffering upon him; cf. Greek

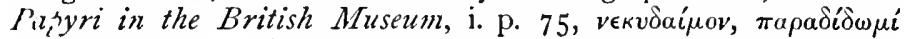

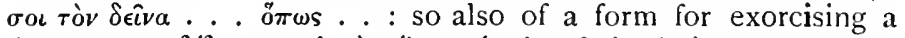

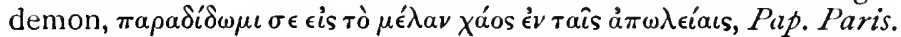
574. In the same way a ceremonial or moral offence against the 
God was punished by infliction of disease; it was only healed after confession of the sin (Deissmann, Light from the East, 1. 304 ; Sir IV. Ramsay, ad loc., and in Expository Times, Oct.Dec. I 898 ).

The punishment implied is either (i) an exercise of the power

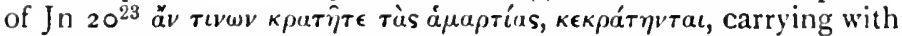
it exclusion from the society, cf. 2 Th $3^{14}$, I Co $5^{11}$, $3 \mathrm{Jn}{ }^{10}$ é $^{\mathrm{t}}$

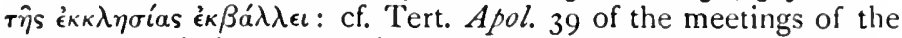
Church for discipline, "judicatur magno cum pondere ... . si quis ita deliquerit ut a communicatione orationis et conventus et

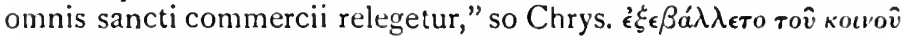
$\sigma v v \varepsilon \delta \rho i o v:$ Theod. "abalienavi ab ecclesia"; or also(ii) the infliction of some bodily suffering: and the analogy of Job, of the Pagan

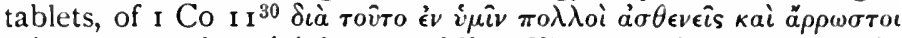

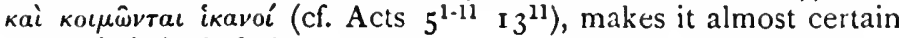
that this is included.

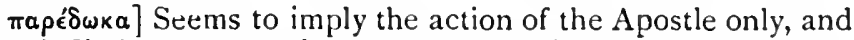
if the infliction was only bodily suffering this would be probable, cf. Acts I $3^{11}$; but the action of the whole community is not excluded; there would be no need to repeat the whole details to Timothy, and it is included in I Co $5^{3-5}$ where the language is

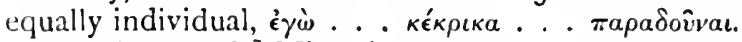

$\mu \grave{\eta} \beta \lambda a \sigma \phi \eta \mu \epsilon i v]$ Might include the thought not to speak evil of us, cf. $6^{4}$, Ttt $3^{2}$; but as the warning is against false teaching, the main thought is not to speak evil of God, to misrepresent His truth, cf. 1 Cu $15^{15}$.

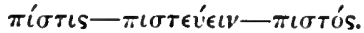

A careful account of the previous history of these words will be found in Burton, Galatians, I.C.C., pp. 475-85; cf. also Hort on ${ }_{1} \mathrm{P}_{\mathrm{I}^{21}}$. Here it will be sufficient to note the usages in these Epistles and to compare them with the earlier Pauline letters. miors $=(a)$ faithfulness, Tit $2^{10}$, and perhaps $\mathrm{I}$ Ti $2^{15} 5^{11}$, $2 \mathrm{Ti}_{2}{ }^{22}$; so $\mathrm{Ro}_{3}{ }^{3}, \mathrm{Gal} 5^{22}$. In both groups the usage is rare.

(b) faith as the essential quality of each Christian life, so passim: as in St. Paul; but whereas St. Paul frequently

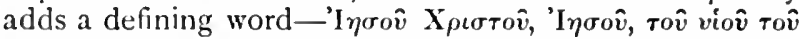

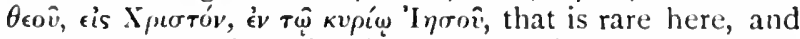

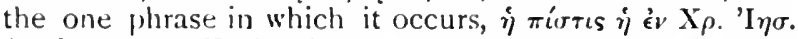
(I $3^{13}, \mathrm{II}_{1}{ }^{13} 3^{15}$ ), is slightly different: "the faith which is found in union with Christ." The object of the faith no longer needs defining.

(c) the principle of faith as characteristic of Christi. anity, and as professed and taught : almost equal to "the Creed," "the doctrines believed"; but it is doubtful 
whether it is ever quite equivalent to that. The strongest

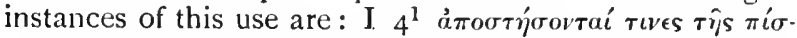

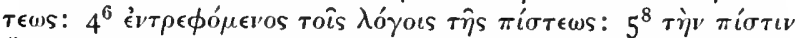

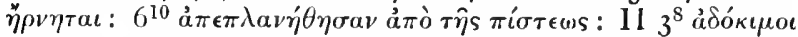
$\pi \epsilon p i \tau i v v i \sigma \tau \iota v$. More doubtful are $\mathrm{I}^{2 .}{ }^{29} 3^{9} 6^{12.21}, 114^{7}$

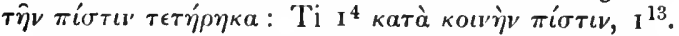

This scarcely goes beyond St. Paul's use of $\dot{\eta} \pi i ́ \sigma \tau \iota s$ :

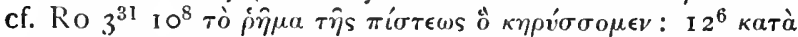

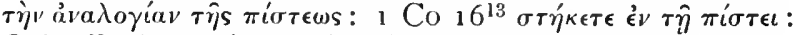

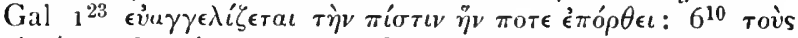

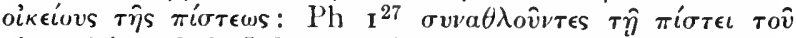

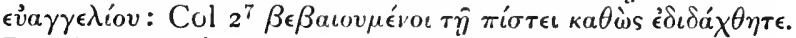
But the usage is more frequent here, and perhaps slightly more fixed.

$\pi \iota \sigma \tau \epsilon$ é $\epsilon \nu=(a)$ to entrust, commit to, $2 \mathrm{Ti}^{1}{ }^{12}$, and in passive I I ${ }^{11}$, Tit $1^{3}$; so Ro $3^{2}$, I Co $9^{17}$, Gal $2^{7}$, I Th $2^{4}$.

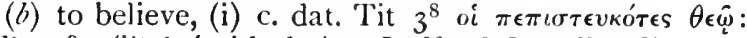
cf. Ro $4^{3}$; (ii) $\epsilon \pi i$ with dative, I ${ }_{1}^{16}$, cf. Ro $9^{33}{ }_{10}{ }^{11}$.

Once in the passive, I $3^{16} ; \mathrm{cf}_{2} 2 \mathrm{Th}^{10}$ (si vera lectio).

In the verb there is no difference in usage.

$\pi\left\llcorner\sigma \operatorname{có}^{\prime}=(a)\right.$ trustworthy: I $1^{12.15} 3^{1.11} 4^{9}$, II $2^{2.11 .13}$, Tit $1^{6}$ (2) $93^{8}$; so 10 times in St. Paul.

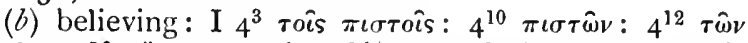

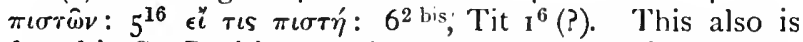
found in St. Paul but much more rarely, Gal $3^{9}, 2$ Co $6^{15}$, and more doubtfully, liph $\mathbf{I}^{1}, \mathrm{Col}^{2}$; but never oi $\pi \iota \sigma \tau o i$ $=$ the believers, the Christian body: yet oi ă $\pi \iota \sigma \tau o \iota$ is a Similarlyregular title for "unbelievers."

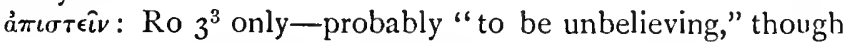
perhaps "unfaithful."

2 Ti $2^{13}$ only-probably "to be unfaithful"

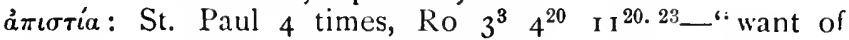
faith," "state of unbelief."

Past. Epp. I ' $\mathrm{Ti}^{13}$ only, in the same sense.

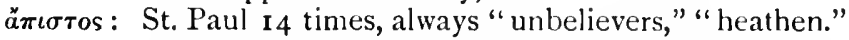
Past. Epp. twice, I Ti $5^{8}$ "unbeliever," 'Tit I $^{15}$ "wanting in faith."

There is then a slight difference from the Pauline letters, and a rather greater fixity of meaning. $\pi i \sigma \tau \iota s$ as the Christian quality is not felt to need a defining object: it approaches nearer to the meaning of a faith professed and taught; and $\pi \iota \sigma \tau o$ 's has become the natural antithesis to "heathen"; oi $\pi \iota \sigma \tau o$, a common term for the Christian Body. The difference is slight and conceivable within St. Paul's own lifetime and in his own writing, but it is noteworthy; cf. also Parry, pp. ciii-cx. 


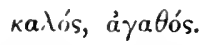

The distinction between áyatos, practically good, morally

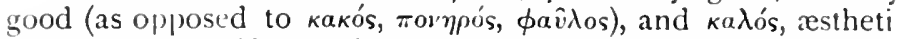
cally good, beautiful, good to men's eyes (as opposed to aioxpós), ${ }^{1}$ is still present in Hellenistic Greek, though the contrast had

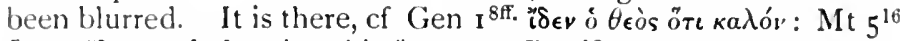

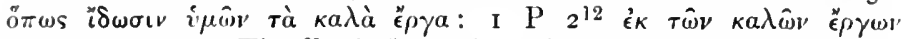

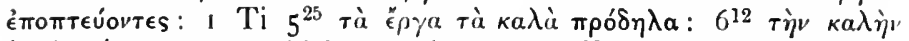

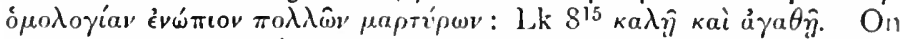

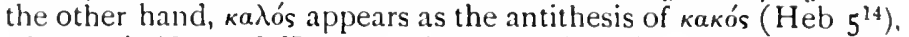

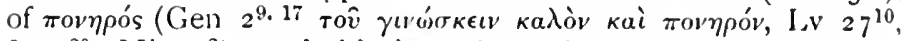
Is $\left.5^{20}, \operatorname{Mic} 3^{2}\right)$ : and this is perhaps the most common usage of it in the N.T. It is clear then that the distinction cannot always be pressed: it may often be a mere desire for euphony or variety which decides the choice between the two words, except where there is a clear reference to the effect upon others.

A comparison of the Pastoral Epistles with St. Paul's earlier

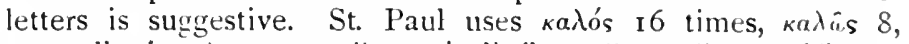
generally in the sense "practically" or "morally good"; cf.

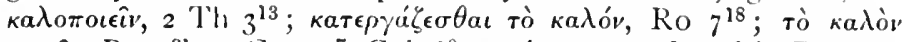
$\pi$ ot $\hat{i v}$, Ro $7^{21}$, 2 Co $13^{7}$, Gal 69, a phrase not found in Pastoral

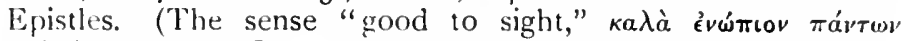
ave $\rho \dot{\omega} \pi \omega \nu$, Ro $\mathrm{I} 2^{17}, 2$ Co 821 , is a quotation from Prov $3^{4}$.) $\mathrm{He}$

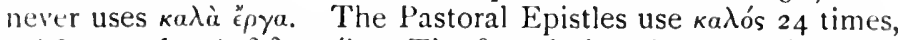

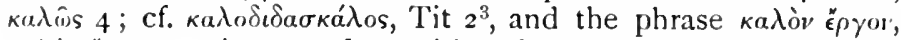
$\kappa a \lambda \dot{a}$ ép $\gamma a, 7$ times: often with reference to a deed as scen

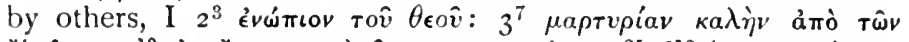

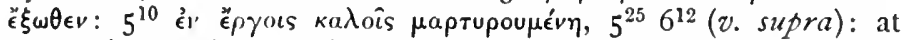
other times with the idea of excellence in contrast to other

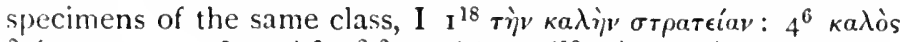

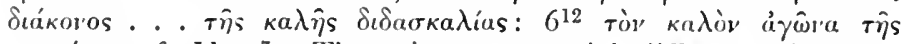
$\pi \iota \sigma \tau \tau^{\prime} \omega \varsigma$ : cf. Il $4^{i}$. There is no essential difference between

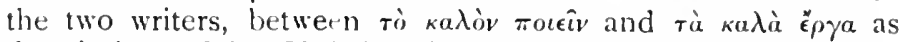
descrijtions of the Christian life, and Pastoral Epistles also use

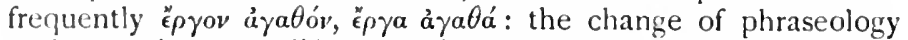
perhaps points to a different writer, but in any case is due to the growing sense in Christian teachers, so marked in I P, that the lives of Christians must be one of the chief means of winning the heathen to Christ: and this would be quite natural to St. Paul, always insistent on the duty of his converts to the heathen world, cf. Gal $6^{10}, \mathrm{Ro}$ I $2^{18}$.

"No one English word will express ka入ós fully, the meaning

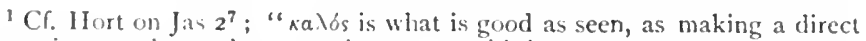
impression on those who come in contacl with it: contrast aratos, which is good in result." 
changing with the context. Thus 'every creature of God is good' ( $\mathrm{r} \mathrm{Ti}_{4}^{4}$ ), i.e. free from defilement, fit for human use. with the Creator's stamp upon it. 'The law is good' ( $\mathrm{r}$ Ti $\mathrm{r}^{8}$ ), valuable, working a good purpose, an excellent instrument in a teacher's hand, if he use it in accordance with that purpose. One who desires a bishopric sets his heart on 'a good task' ( $\mathrm{I} \mathrm{Ti}^{1}{ }^{1}$ ), on an honourable post that sets him before the world's eye, and that requires constant labour: he must rule his family with dignity and success ( $\mathrm{I} \mathrm{Ti} 3^{4}$, cf. $5^{17}$ ), he must have an excellent reputalion from those without $\left(\mathrm{r} \mathrm{Ti}^{7}\right)$ : the deacon who gains distinction ( $\kappa \alpha \lambda \hat{\omega} s$ ) acquires a distinguished position for higher service ( $1 \mathrm{Ti}^{13}$, cf. $4^{6}$ ). The widow must not only have taken part in every good work $\left({ }_{\epsilon}^{\prime \prime} \rho \gamma \omega \dot{a} \gamma \alpha \theta \hat{\omega}\right)$, but be well reported

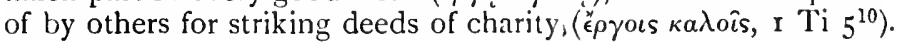
The Christian soldier must endure hardness as a well-trained soldier $\left(2 \mathrm{Ti}^{3}\right)$, engaged in a noble struggle ( I Ti $6^{12}, 2 \mathrm{Ti}_{4}{ }^{7}$ ) in the most honourable of all campaigns ( $\mathrm{T} \mathrm{Ti}$ ${ }^{18}$ ). The doctrine which he preaches is attractive, winning, with the glow of healthy life upon it ( $\mathrm{I} \mathrm{Ti}_{4}{ }^{6}$, Tit $2^{1.7}$ ). Timothy's public profession had something heroic about it, as had that of his master $\left(\tau \grave{\eta} \nu \kappa a \lambda \dot{\eta} v \delta \mu o \lambda o \gamma i \alpha \nu\right.$, I Ti $6^{12.13}$ ): 'Titus is to be an example of 'excellent' works (T'it $2^{7}$ ): the rich are not only to do good ( $\alpha \gamma \alpha \theta 0 \epsilon \rho \gamma \epsilon \hat{i \nu})$, but to use their wealth for works of special

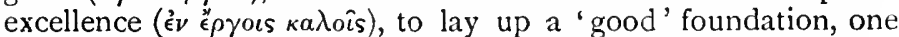
well-laid, a sound base for an eternal life (I Ti 6 ${ }^{18.19}$ ). All members of the Christian family are to take the lead in honest, honourable occupations (Tit $3^{14}$ ), for this is the duty of those who believe in God, who had purified unto Himself a peculiar people for the very purpose that they should be zealous for works that should rise above the level of the world and exhibit the beauty of holiness ( $\zeta \eta \lambda \omega \tau \grave{\eta} v \kappa a \lambda \hat{\omega} \nu$ $\epsilon^{\prime} \rho \gamma \omega \nu$, Tit $2^{14}$, where Theo-

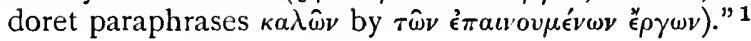

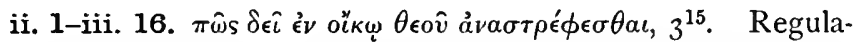
tions for the Church, as regards (a) public worship, the proper objects of prayer $\left(2^{1-7}\right)$, and the position to be occupied by inen and women $\left(2^{8-15}\right) ;(6)$ qualifications for the officers: the bishop $\left(3^{1-7}\right)$, deacons $\left(3^{8-10.12 .13}\right)$, deaconesses $\left({ }^{11}\right)$.

ii. 1-7. Paraphrase. I come to special regulations to guide you in your true work, and I want to urge first of all that Christians should realize the universality of the message of the gospel. For this, prayers and thanksgivings are to be made in public worship for all mankind, and primarily for rulers and all in any position of authority, that so we may be able to live a quiet life

${ }^{1}$ From my St. Paul the Master Builder, p. I18. 
undisturbed by war and persecution, in a religious and serious spirit. Such prayer is true prayer and well-pleasing to God who has already saved us, but wishes all men to be saved too, and to reach a full knowledge of truth.

For there is one and one only God, one and one only who stands between God and men, He who shares human nature, Christ Jesus, and He gave Himself in life and death for all mankind, so bearing witness to God's great Love in God's own time; and it was to carry on that message that I myself was chosen as a herald, as a commissioned Apostle-yes, whatever my opponent may say, that is true: He did commission me-whose one task is to train Gentiles in the spirit of faith and in truth.

The keyword of this section, as of the Epistle to the Romans,

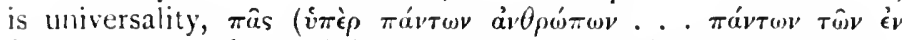

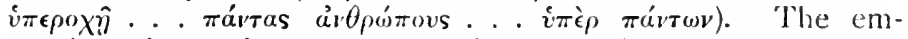
phasis on it may be due to Gnostic tendencies to exclusiveness, laying undue stress on knowledge, and distinguishing between

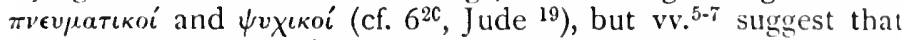
it is rather due to Jewish exclusiveness. St. Paul would naturally be anxious that the Christian Church should not fail, as the Jews had done, in recognizing the universality of its mission.

1. oưv marks the return from a digression to the main subject, but perhaps suggesting a logical connexion. "Since, then, our one object is to produce love $\left(\mathrm{I}^{5}\right)$, and to carry the message of salvation to all sinners $\left(x^{15}\right)$, there must be prayer for all men." Chrysostom has some excellent remarks upon the power of intercession to break down the barriers of prejudice.

$\pi \rho \hat{\omega} \tau o v \pi a ́ v \tau \omega v]$ Because worship gives the note which action has to take up.

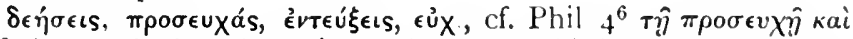

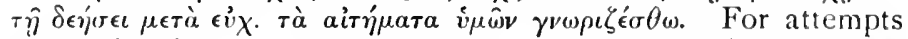

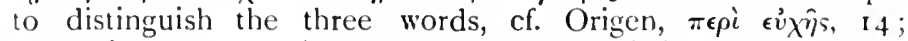
Augustine, Ep. 50 (who refers them to distinct parts of the Jiturgy), Bengel, and Bernard. Probably $\delta \in \eta^{\prime} \sigma \iota s$ emphasizes the

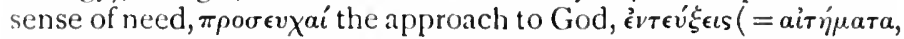
Phil $4^{6}$ ) the actual petition, but the distinction was not meant to he emphasized: the triad is a favourite feature in St. Paul's style. The connexion with ${ }^{8-15}$ and the effect of this passage on the Liturgies makes it clear that the primary reference is to public

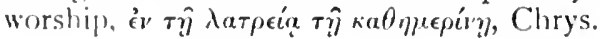

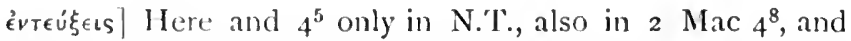

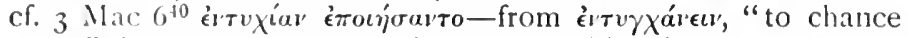
upon," then "to have an audience with a king," to have the good fortune to be admitted to an audience, so to present a petition : 


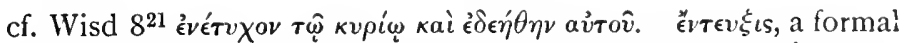
petition, especially to a king; so frequently in Josephus, Diodorus, and the Papyri (Deissmann, B.S., pp. I2 I, 146). The thought of the King of the ages, $\mathrm{I}^{17}$, may still be in the writer's mind.

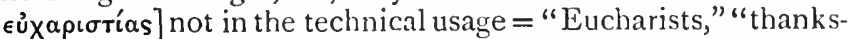
givings in offerings"; cf. Lightfoot on Clem. Rom. i. 4I, and the careful examination of the use of the word by Dr. Swete (J. Th. St. iii. p. 16r ) and Dr. Hort (ib., p. 594); but "thanksgiving in words," thought of as part of common worship, cf. I Co $14^{16}$. It will include gratitude for the past kindnesses of those

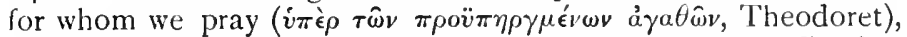
for God's past mercies to them (Chrys. quoting Mt $5^{45}$ ); but more widely-for what they are, God's creatures, the object of His love, whom He wishes to be saved. Chrysostom says finely,

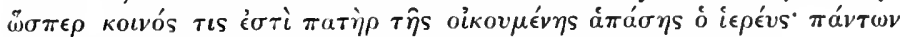

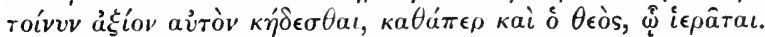

úmép $\pi \dot{v} v \tau \omega v \dot{a} v \theta \rho \omega \dot{\pi} \omega v]$ There is no one for whom the Christian Church has not 10 pray; no one for whose creation it has not to thank God! Even for God's enemies its duty is "et quod facti sunt diligere et quod faciunt increpare: mores pravorum premere, vitæ prodesse" (Gregory, Reg. P'ast. iii. c. 22).

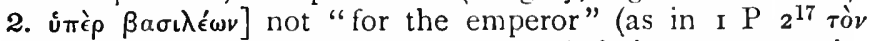
$\beta a \sigma \iota \lambda \epsilon ́ a \tau \iota \mu \hat{a} \tau \epsilon)$, but "for emperors," the rule being meant to be universal and lasting; cf. Tert. Apol. 30 , "pro omnibus imperatoribus"; or perhaps "for kings," including local kings under the Empire; cf. Mk $13^{9} \dot{\epsilon} \pi i \dot{\eta} \gamma \epsilon \mu o ́ v \omega \nu$ кai $\beta \alpha \sigma \iota \lambda \hat{\epsilon}^{\prime} \omega \nu$. The duty is emphasized perhaps because of the Jewish tendency to rise against the Empire ("Judæos assidue tumultuantes," Suet. Cl. 25), which might pass over into the Christian Church under a misapprehension of Christian liberty (cf. 6 $6^{\mathrm{I} .2}$, I $\mathrm{P}_{2^{16}}$ ), and under the stress of persecution and growing suspicion (Tac. Ann. xv. 44); but apart from this it would be natural to St. Paul with his pride in the Empire and its citizenship, Ro $\mathbf{I}_{3}$.

Compare Jeremiah's advice to the Jews in Babylon, $\pi \rho 0 \sigma \epsilon v^{\prime} \xi \alpha \sigma \theta \epsilon$

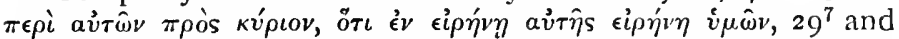

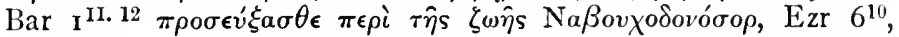
I Mac $7^{33}$. The later Jews prayed "for the peace of the kingdom, since but for fear thereof we had swallowed up each his neighbour alive," Pirke Aboth, iii. 2, and prayed for the emperor in their sy nagogues (Philo, ad Flaccum, p. 524 ), and offered sacrifices twice a day in Jerusalem for the emperor and people of Rome; but this was stopped with the outbreak of the last Roman war, Jos. B.J. ii. Io and I 7 ; cf. Abrahams, Studies in Pharisaism, $\S$ viii.

For a similar command, probably based on this, cf. Polyc. Ep. 12 (ubi v. Lightfoot); and for the substance of the prayer,

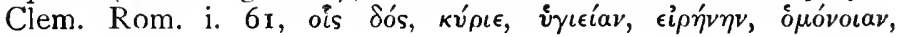




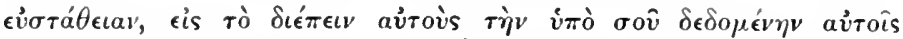

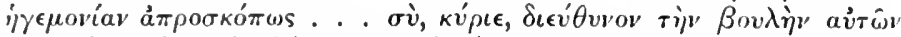

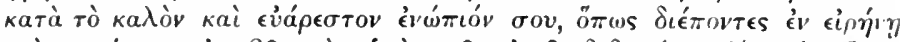

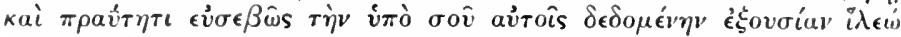

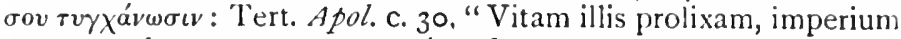
securum, domum tutam, exercitus fortes, senatum fidelem, populum probum, orbem quietum"; ib. c. 39 , "Oramus pro imperatoribus, pro ministeriis eorum ac potestatibus, pro statu sæculi, pro rerum quiete, pro mora finis." For the effect of this passage

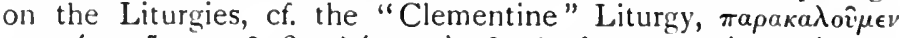

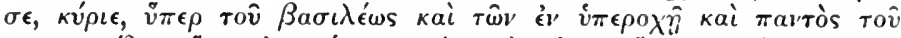

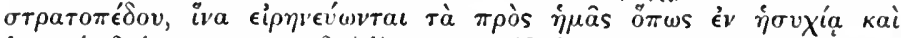

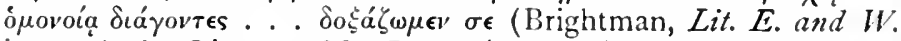
i. p. 21 ), the Liturgy of St. James (ib. p. 55), the Coptic Liturgy (ib. p. 168), the Prayer for "the whole state of Christ's Church" in the English Prayer Book.

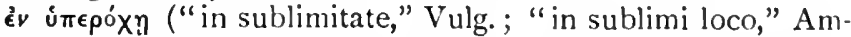
brosiaster): here and I Co $2^{1}$ only in N.T., but cf. Ro I $3^{2}$

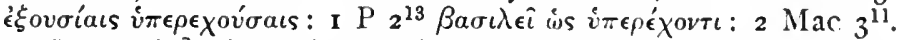

iva k.T.A.] gives the result of the prayer. Pray for good government, for that will secure you a quiet life. Perhaps also (so Holtzmann) dependent on $\pi$ olei $\sigma \theta a$, giving the result of the fact that they pray. Pray for the government, that the heathen may recognize your loyalty and you be left in peace. Cf. Tertullian, Apol. 39, and Seneca (Ep.Mor. 73), who defends philosophers from the charge of disloyalty to rulers, " $\mathrm{e}$ contrario nulli adversus eos gratiores sunt: nec immerito: nullis enim plus præstant quam quibus frui tranquillo otio licet."

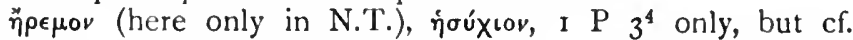
$\dot{\eta} \sigma v \chi^{a} \zeta \epsilon \iota v$, I Th $4^{11} ; \mu \epsilon \tau \dot{a} \dot{\eta} \sigma v x i a s, 2$ Th $3^{12}$, a retired and quiet life (cf. M.M. s.v.), undisturbed by war or persecution from outside ; free from such tumults as that at Ephesus had been Acts $19^{23}$.

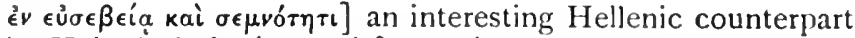

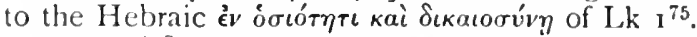

$\epsilon u ̛ \sigma \in \beta \in i a]$ ("pietate," Vulg.) godliness; the true reverence towards God which comes from knowledge; characteristic of Past. Epp. here and $3^{16} 4^{7.8} 6^{3.5 .6 .11}, 2$ Ti $3^{5}$, Tit. $1^{1}$, but also in Acts and $2 \mathrm{P}$, and common in LXX and classical literature; cf. Bernard and Trench, Syn. s.v. It may include a true respect and reverence for human superiors (cf. $5^{4}$ ), and perhaps does so here.

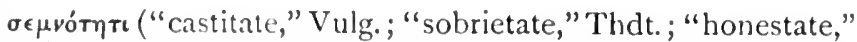
Calvin), dignity, gravity, seriousness, the demeanour of the $\epsilon \dot{v} \sigma \epsilon \beta$ ' $/$ s towards men (cf. 'lert. Prescr. 43, "ubi metus in Deum, ibi gravitas honesta"): "a grace and dignity not lent him from earth, 
but which he owes to that higher citizenship which is also his: being one who inspires not respect only, but reverence and

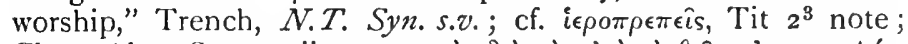

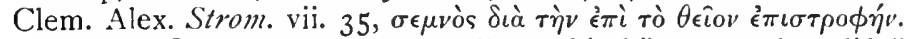

3. тойтo] "Such prayer for all mankind," or "such a life" (so Pelagius, von Soden): either will help on God's purpose and help to save men. Cf. Euseb. H.E. iv. 7 , who speaks of the

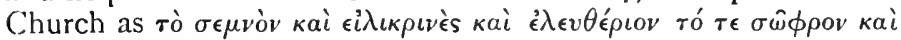

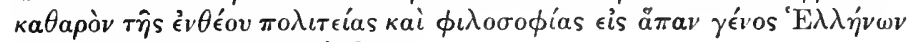

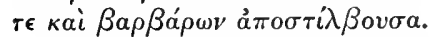

кa入óv] Cf. additional note, p. 22. Here it may be joined

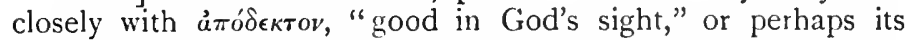
reference is manward. This will win men and please God. Cf.

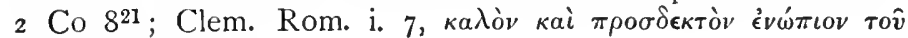

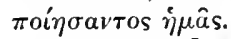

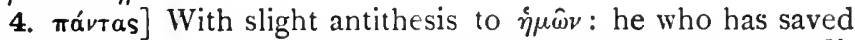
us, ${ }^{3}$ including the chief of sinners $\left(1^{15}\right)$, wills to save all, cf. $4^{10}$, IVisd $16^{7} \delta \iota \grave{a} \sigma \epsilon^{\prime} \tau \grave{\nu} \nu \pi \alpha ́ v \tau \omega \nu \sigma \omega \tau \hat{\eta} \rho \alpha$. There is no limitation, such as Tertullian, "eorum quos adoptavit" (de Or. 4); Augustine, "omnes prædestinati, quia omne genus hominum in eis est" (de corr. et gr. 44). His will to save is as wide as His will to create and to protect, "omnes vult salvari quia et omnes tuetur" (Thd.-Mops. ad loc., with Swete's note); cf. Ezek $18^{23}$, Wisd $1^{13-16}$,

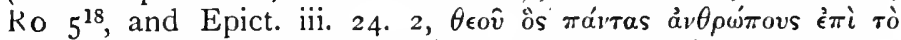

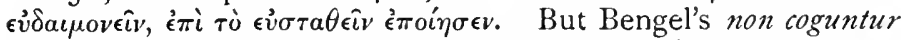
and Ambros. si et ipsi velint add the necessary limitation to the working of God's will; cf. Herm. Sim. viii. I ; Hooker, Eccl. Pol v. 49 .

$\epsilon \dot{\epsilon} \boldsymbol{i} \gamma v \omega \sigma \omega]$ Favourite word with St. Paul (ro times; see Armitage Robinson on Eph., detached note); elsewhere Heb. (1), 2 P (4).

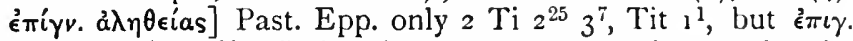
$\tau \hat{\eta} s{ }_{a} \lambda \eta \theta$., Heb $10^{26}$. It has become a techn'cal term for the intellectual acceptance of Christianity; cf. $\mu \epsilon \tau \alpha v a \sigma \tau \grave{\alpha} s \epsilon i s ~ a ̉ \lambda \eta \theta \epsilon i a v$ of the proselyte to Judaism, Philo, de Spec. Leg. 4. I 78 (Dibelius),

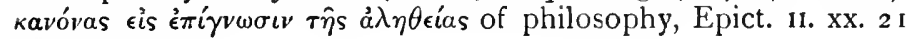
(M.M. s.v.).

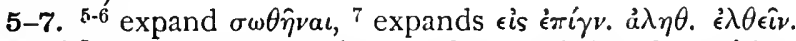

5. $\epsilon i s]$ Correlative to $\pi \alpha^{\prime} v$ sas. One, and therefore with a will for all mankind, for Gentile as well as Jew; cf. Ro $3^{29.30} \hat{\eta}$

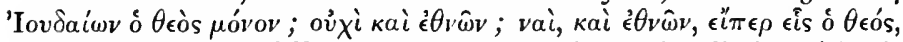
Eph $3^{4-6}$ and Is $45^{20-23}$. There may also be an implied antithesis "one and not many" (cf. I Co 84-6).

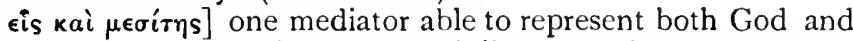
man entirely (cf. Iren. iv. 20, "hominibus osteridens Deum, Deo autem exhibens hominem"), again with an implied antithesis, one and not more: not Moses any longer $\left(\mathrm{Gal} 3^{19}\right.$; Philo, de Vita 


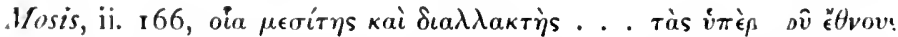

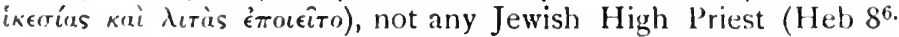
$9.15{ }_{12}{ }^{21}$ ), nor any angel (Col ${ }^{18}$, Heb $2^{16}$; Test. XII. Patr.,

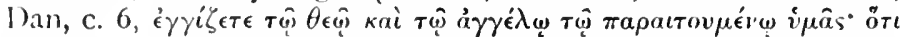

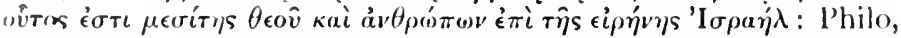
Bibl. Antiq. xxxii. 14), nor any being in the mysteries intermediate between (rod and the creation, like Mithras (Cumont, Les mystires de Mithra ${ }^{3}$, pp. 1 29, 139), nor any Gnostic xon intermediate between God and the world. Philo had regarded the Word of Cod as occupying such an intermediate position; cf. Quis rerum

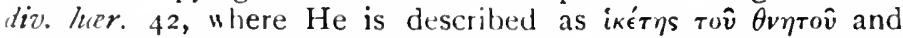

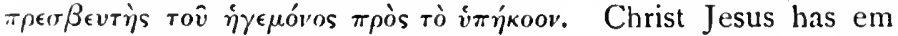
bodied this function in a human life.

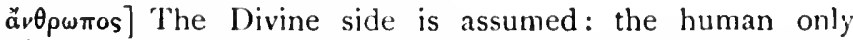
mentioned, as he is thinking of the gift given in the human life, a true man, no angel, no mere phantom appearance, but one living a human historic life, a "second Adam," "The Son of man." 'There is much to be said for Lachmann's punctuation, putting the comma after a ${ }^{\prime} \theta_{\rho} \omega \pi$ os. For there is one only God, one only man too, representative of God and man, viz. Christ Jesus.

6. ó Soùs éautóv] prob. a reminiscence of the Lord's own saying,

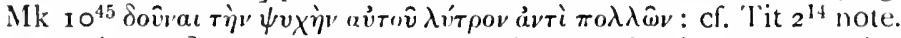

ávrílutpor] Here only in N.T.: in Ps $48^{9}$ it is an alternative

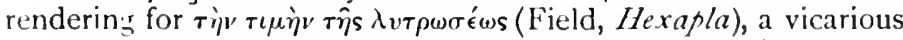

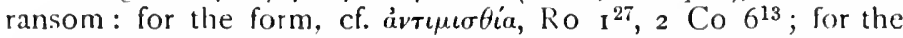
thought, 'Tit $2^{14}$ note, and cf. Eleazar's prayer that the sacrifice of

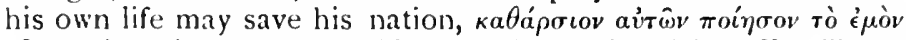

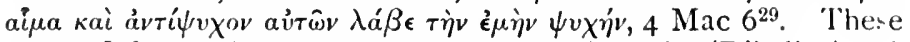
verses ${ }^{5.6}$ may be quoted from some formula (Dibelius), cf. I Co $8^{6}$, but they spring naturally out of the context.

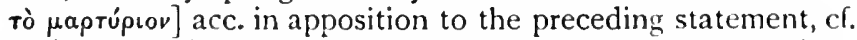
Ro $12^{1}, 2$ 'Th $1^{5}$ : the great truth revealed in God's own time. But by whom? It may include the whole chain of witnesses. (a) The law and the prophets pointing to it, cf. Ro $3^{21} \mu \alpha \rho \tau v \rho o v \mu \epsilon \operatorname{s} \eta$ vimo

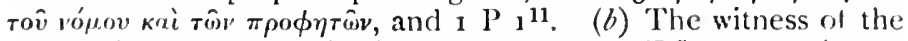

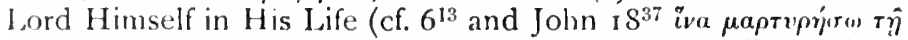
à $\eta \theta \epsilon i a c$ and $1 \mathrm{P}_{1}{ }^{11}$. "Sancte vitre dedit exemplum," Pelagius),

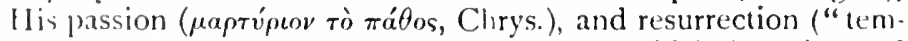
pore quo resurrexit," Thd.). (c) The witness w hich the writer and all future teachers have to give, $\mathrm{cf}$. $\mathrm{I} \mathrm{Co}_{\mathrm{I}} \mathrm{w}_{2} \mathrm{Th} \mathrm{I}^{10}$. "This is the fact to which we are to bear our testimony, as opportunities present themselves," Truentieth Century N.T. "The outlook is to the future of the Church," Bernard. "This suits the context, ordering prayers for all wen that so the message of salvation may reach to all: and this will need time. But 'Tit $\mathbf{I}^{3}$ makes any reference to the future doubtful. 
kaıpois idioıs, cf. Tit $\mathbf{I}^{3}$ note.

7. Gis ồ ét $\left.\epsilon^{\prime} \theta \eta v\right] 2$ ' $\mathrm{Ti} \mathrm{I}^{\mathrm{ll}}$, and supra, $\mathrm{I}^{13}$ note.

кńp $\xi]$ The word was associated not only with the games ( $1 \mathrm{Co} 9^{27}$ ) but also with the Eleusinian mysteries; cf. rov 'E $\mathrm{E} \lambda \epsilon$ ouviov iepov $\kappa \hat{\eta} \rho v \xi$, Philostratus, Vit. Soph. ii. 33, and other instances, $a p$. M.M. s.v.

$\dot{a} \lambda \eta \theta$. $\lambda \hat{\epsilon} \gamma \omega]$ Ro $9^{1}, 2$ Co ${ }_{1}^{31}$, Gal $r^{20}$. The language of one whose authority and whose truthfulness have been attacked in the past, and who is still face to face with opposition.

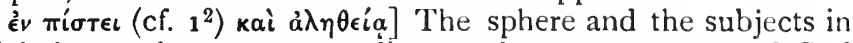
which he teaches; corresponding to the two purposes of God in ${ }^{4}$, faith in salvation and knowledge of Him. It may include his own loyalty $\left(\mathbf{r}^{12}\right)$ and truthfulness (cf. $\alpha^{\prime} \lambda \eta \theta \epsilon^{\prime} \alpha \nu \lambda^{\prime}{ }^{\prime} \gamma \omega$ ) (so Wohlenberg); but only by implication.

8-15. Paraphrase. The second point which I wish to stress is the spirit and order of public prayer. Men when they pray to God must lay aside all personal ill-will and irritation; women must dress quietly, for they are engaged in a sacred task, and their true adorning is that of good works, not of costly jewels and dress. The women should listen to the teaching quietly and submissively: I do not allow a woman to be herself a teacher, nor to dictate to men; and that for two reasons. The order of creation suggests man's taking the lead, first Adam, then Eve. The history of the Fall suggests women's weakness : it was not Adam but Eve who was deceived and so fell. Yet God's will to save all men extends to her:

\section{"A child from woman's seed to spring Shall saving to all women bring."}

That is a true saying; but to be saved they must continue faithful, loving, holy, and self-controlled.

The whole section refers primarily only to public prayer (though it appeals at times to principles that have a wider application); this is clear ( $a$ ) from its position between ${ }^{1-8}$ and $3^{1-13}$. (b) From the analogy of 1 Co $\mathrm{II}^{2-16} \mathrm{I}_{4}^{34-36}$ which were apparently in the writer's mind. (c) From its influence on subsequent Church orders; cf. Canon. Hitpol. \$§ 8I-88, "mulier libera ne veniat veste variegata in ecclesiam . . . neve omnino loquantur in ecclesia quia est domus Dei." Test. Dom. Nostri, ii. 4 ; Const. Apost. iii. 6 ; cf. Clem. Alex. Pad. iii. I I , émi

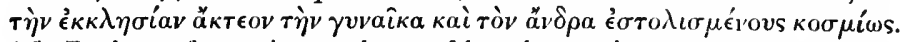
(d) Perhaps from the analogy of heathen priestesses ; cf. 10 note.

The purpose of the section is twofold. (a) Primarily, to secure a right spirit and character in those who pray, both men and women; cf. ${ }^{8.9 .10 .15}$. (b) To check a freedom which 
women were claiming to teach at the meeting. Nothing is men tioned about women prophesying, which was always exceptional, and the writer is laying down general rules. It is less clear whether any rule is laid down as to leading the prayers. This is not stated, and the language is consistent (i) with the theory that there was no leader, but that all prayed in silence until the Spirit moved some one, man or woman, to pray aloud (cf. Ramsay, E.x., Sept. 1909): (ii) with the theory that the érírколо acted as leader, the rest joining in with the Amen (I Co ${ }_{14}{ }^{16}$ ). This is more consistent with ${ }^{1.2}$ supra, and $3^{1-7}$.

8. Boúdopar (cf. $5^{14}$, 'Tit $3^{8}$, Phil $\mathrm{I}^{12}$ ) oủv, parallel to 1 , but perhaps suggesting a slight connexion with the last paragraph. 'The thought of God's universal salvation is still in his mind, $\sigma \omega \theta \hat{\eta} v a \iota,{ }^{4} ; \sigma \omega \theta \eta_{j} \sigma \epsilon \tau a,{ }^{15}$, and the ideal of the true Christian life; cf. ${ }^{2}$ with ${ }^{9-11}$.

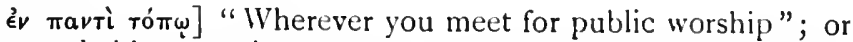
more probably the writer means the rule to be universal for all churches under his influence, $\pi \alpha \tau^{\prime} i$ being an echo of $\pi \alpha^{\prime} v$ tas $\left({ }^{4}\right)$,

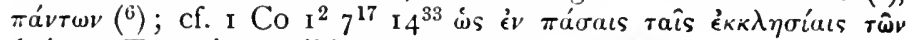

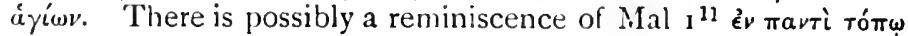

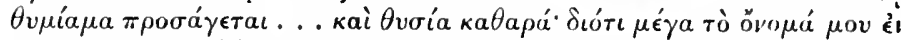

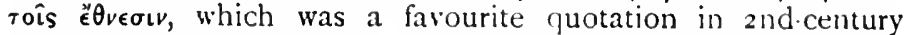
writers, as pointing to the universal offering of the Eucharist; cf. Justin, Dial. 4 I and 117 ; Iren. iv. I 7 ; so Didache, c. 14 , where it is given as a reason why no one who has a quarrel with another should join in the Eucharistic sacrifice.

émaíportas xeipas] Standing to pray, as was customary with pagans and Jews alike, and common with the early Christians; cf. Dict. Chr. Antiq., s.v. Oranti. For Greek and Roman illustrations, cf. Wetstein, Wohlenberg, and Deissmann, L.A.E., p. $42 \mathrm{I}$. ơoious Xeipas] Combines the idea of moral purity ("qua sanctis operibus ministraverint," Origen on Ro 6 ; cf. Job $16^{17} \ddot{a} \delta \iota$ коv $\delta \grave{\epsilon}$

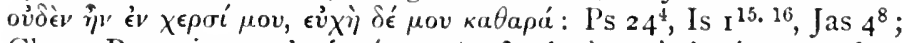

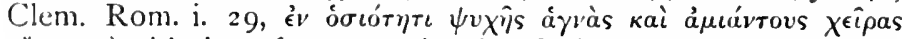
a priests, performing the tasks of holy priesthood $\left(\begin{array}{ll}1 & P_{2}{ }^{9}\end{array}\right)$. It is

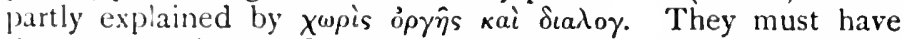
the consecration of Christian Love, if they are to pray aright. Cf. 'Tert. Apol. 3o, "manibus expansis quia innocuis"; De Orat. I 4, "manus expandimus, de dominica passione modulati," in imitation of the Cross. It is difficult to inmagine after Our Lord's teaching that Christians had taken over the Jewish practice of ceremonial ablutions. So Ramsay, ubis, but cf. Hippol. Canon, $\$ 24 \mathrm{~J}$, "Christianus lavet manus omni tempore quo orat."

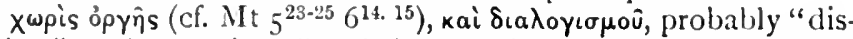
puting "("disceptatione," Vulg.); cf. Phil $2^{14} \chi^{\omega \rho i s} \gamma \sigma \gamma \gamma v \sigma \mu \hat{\omega} v \kappa a i$ 


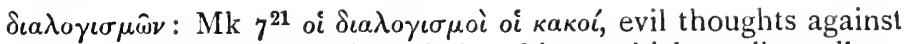
one's neighbour, the chief of the things which really pollute.

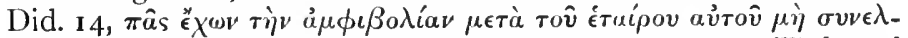
$\theta \dot{\epsilon} \tau \omega \dot{v} \mu \hat{\imath} v, \tilde{\epsilon} \omega s \delta \dot{\delta} \iota \lambda \lambda a \gamma \hat{\omega} \sigma \iota v$. Tertull. De Or. I I. 12. 'Thd. and l'hdt. interpret it as "doubt," "hesitation " (cf. Mk I I ${ }^{23}$, Jas $\mathbf{I}^{6}$, Herm. Mand. ix. I); with right feeling to man and God, with love and faith (cf. ${ }^{15}$ and ${ }_{1}{ }^{14}$ ); but the idea of doubt is alien to the context, which emphasizes man's relation to his fellow-men.

8-15. This section deals only with the dress and conduct of women at the meetings; but compare the general relation of husband to wife in $1 \mathrm{P}^{1-8}$, which appears to be influenced by the passage; cf. also Cyprian, De Hab. Virg., where an $a$ fortiori argument is drawn from this passage to the ordinary dress of virgins, and Tertull. De cultu Fem., where it is used as an argument for the ordinary dress of all Christian women, who may have to face martyrdom at any moment. Compare also the

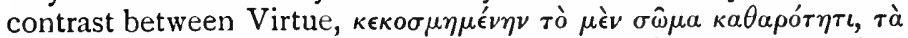

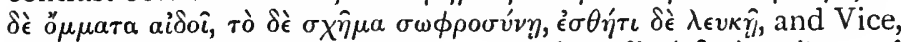

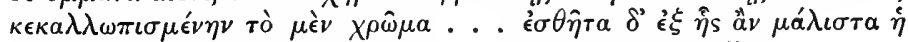
$\ddot{\omega} \rho \alpha \delta \iota \alpha \lambda a ́ \mu \pi o \iota$, in the story of Prodicus, Xen. Mem. ii. I.

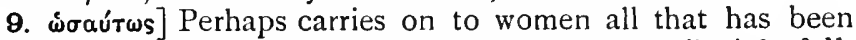
said about men (Chrys., Ramsay), but not necessarily (cf. $3^{8.11}$,

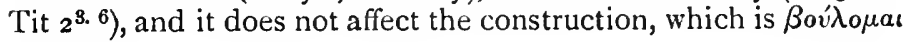

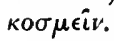

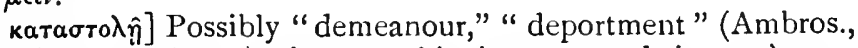
Dibelius, M.M. s.v.); but as this is expressed in $\mu \epsilon \tau \grave{a} . .$. $\sigma \omega \phi \rho \sigma^{\prime} v \eta s$, more probably "dress," which is implied by the

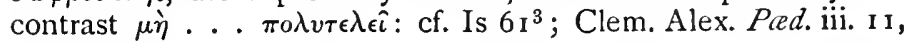
quoted above.

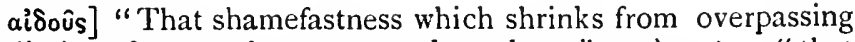
the limits of womanly reserve and modesty"; kai $\sigma \omega \phi \rho$. ., "that habitual inner self-government with its constant rein on all the passions and desires which would hinder temptation from arising, or at all events arising in such strength as should overbear the checks and barriers which aiow's opposed to it." Trench, Syn. s.v.; cf. Tert. de C. Fem. ii. 8, "ubi Deus, ibi pudicitia, ibi gravitas, adjutrix et socia ejus." For its meaning as applied to different ages and sexes, cf. additional note, p. 148.

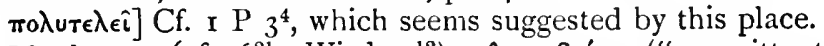

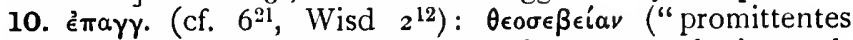
castitatem," O.L. ; "pietatem," Vulg. Ambros. ; "professing godliness," R.V., A.V.; but better, "promittentibus Deum colere," Thd., "that professe the worshippynge of God," Tyndale), refers to their action in coming to the Church's worship. There is perhaps a comparison with heathen priestesses ; cf. ócious $\chi \epsilon \hat{\imath} \rho \alpha{ }^{8},{ }^{8}$; $i \in \rho o \pi \rho \epsilon r \in \hat{s}$, Tit $2^{3}$, and an inscription describing the dress of the 


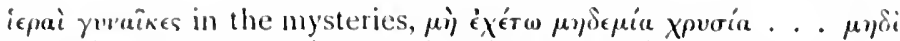

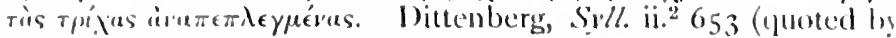
Dibelius) ; cl. "lert. de C. Fr. ii. 1 2, "sacerdotes pullicitie."

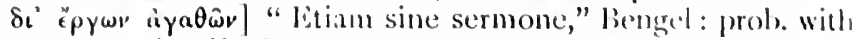

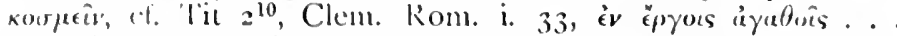

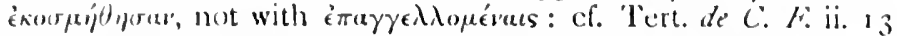
for a rhetorical expansion of this passage, and Hipp. Canow $S_{2-S_{7}}$, "Neque enim tu que pretiosorum lapidum et margarı tarum ornamentis superbis tam pulchra es ut illa quae sola natura "t bonitite splendet."

11-15. Still dealing directly with conduct at the meetings; but the word inoray sugerests a reference to the whole relation of wife to husbambl, ef. Eph $5^{23}$ The language is coloured

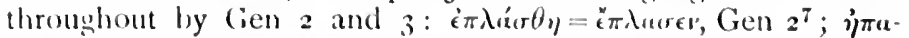

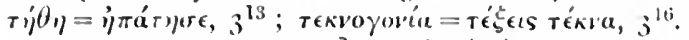

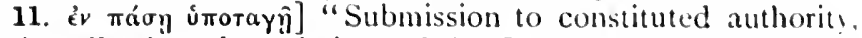
i.e. the officials and regulations of the Church," Ramsay, thougl, máory sugretests also "their husbands."

12. aúbevteiv] The earliest known use of the word, common in

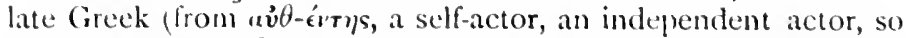
in vulgar (ireck $=\delta \epsilon \sigma \pi o ́ r y s$ (cf. Rutherford, The leze Phrymchus, $\$ 96$; Nägeli, p. 49; Moulton and Milligan, s.v.), "to lord it over," "to dictate to," the antithesis of airós oov nupetioet, Gen $3^{16}$.

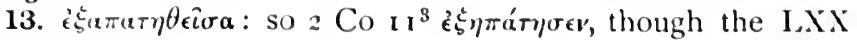
has irrúryiret.

14. Cf 2 Co $x^{3}$; and for the Jewish tradition that Eve was tempted by the serpent to infidelity, cf. 'Thackeray, The R'elation of St. Paul to Contemporary Jearish Thoushth, Pl). 50-57; for the Jewish attitude to women, Taylor, Sitring.s of the Jearish fiathers, i. 5 note; and for the connexion of live with trans-

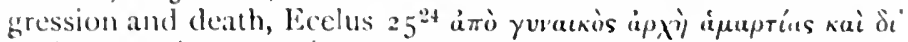

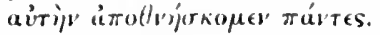

yeyórel-passed into and has remained in the position of transuressor.

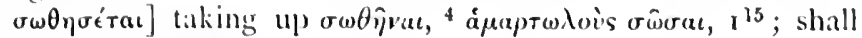
be spirttually saved.

Six rîs ("that of Gen $3^{10, "}$ or more technically " the great") rexvopovias. "Two interpretations seem possible. (a) "By bearing children," by that child-bearing which was once a thing of sorrow but now has become a source of salvation; not by spiritual activities at the meetings, but by motherhood and the quiet clutie's of home (cf. $5^{14}$ ); including perhaps (so Chrys.) the rearins of ehildren (of. $5^{10} \epsilon i$ étenventpópyoel, and Hippol. Canon Sz, "Neve det infintes quos peperit nutricibus sed ipsa sola eos nutriat . . neve administrationem familie negligat"), and all 
maternal instincts, which become the saving of a woman from self and draw out her soul both to others and to God; cf. Ramsay, Expositor, 1909, pp. 339-47. If so, there may be an implied protest against those who depreciated marriage, $4^{3}$.

(b) By the great child-bearing, by that which has produced the Saviour, the child-bearing of Mary, which has undone the work of Eve. This use of the article is very common in the

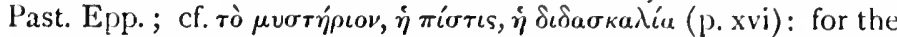

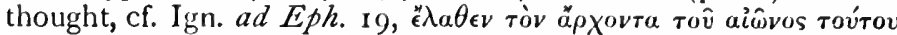

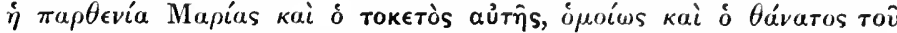
кupíov, Iren. Har. v. I 9, "si ea inobedierat Deo, sed hæc suasa est obedire Deo, uti Virginis Eve virgo Maria fieret advocata, et quemadmodum adstrictum est morti genus humanum per virginem, salvetur per virginem": cf. ibid. 3. 22 ; Pradic. Apostolica, c. 33 ; Justin, Dial. c. roo; Tert. de Carne, xli.

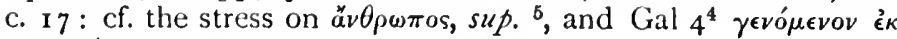
үuvackós.

(b) is probably right. It was given by some anonymous commentator (Cramer, Catena, vii. 22 ), and has been revived by Ellicott, von Soden, and Wohlenberg. Indirectly it reflects a glory upon all child-bearing, which has become the channel of the Salvation of the world.

The nominative to $\boldsymbol{\sigma} \boldsymbol{\omega} \theta \dot{\eta} \boldsymbol{\sigma} \epsilon \boldsymbol{\tau} \boldsymbol{\iota} \iota$ is perhaps Eva (cf. Irenæus, u.s.), or $\dot{\eta} \gamma u ́ v \eta$; Eve as the representative of women.

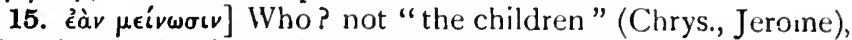
which is too far from the context, but $\gamma$ vvâkes, from 9.10 ; or possibly "husband and wife," suggested by ${ }^{12-14}$; cf. I $\mathrm{P}_{3}^{7}$

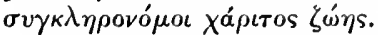

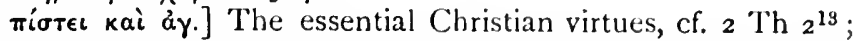

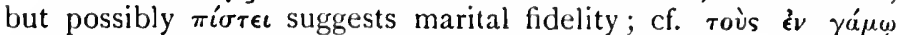

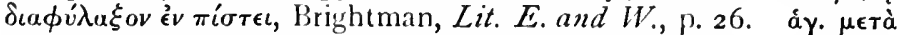
$\sigma \omega \phi \rho$. the right relation between busband and wife, cf. I Th $4^{7}$, and a rhetorical amplification of the section in Clem. Hom.

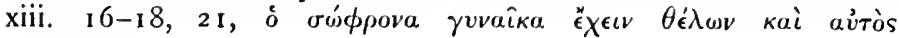
$\sigma \omega \phi \rho o v \epsilon \hat{\imath}$.

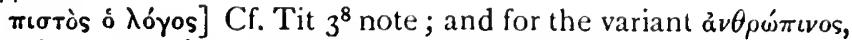
Introd., p. xxxvi. The words perhaps refer to the preceding statement (so Chrys., Holtzmann, IV.-H., Hillard), as the other faithful sayings deal with salvation. If so, it is still uncertain how much of that sentence is included in the quotation; prob-

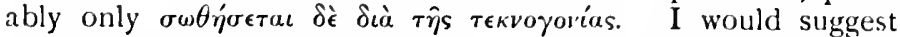

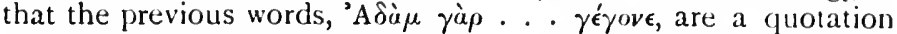
from some Jewish Apocrypha, scornful of women (I his would] make the perfect tense $\gamma \dot{\epsilon} \gamma o v \epsilon$ more natural), which is answered by quoting a well-known Christian saying about the effect of the Incarnation on women. 
But most editors connect the words with the following paragrapl.

iii. 1-13. 'The officials of the Church: (a) the overseer, the bishop $\left({ }^{1-7}\right)$; (b) ministers, deacons $\left({ }^{8-10}\right)$; $(c)$ deaconesses, $\left.{ }^{11}\right)$; (d) the deacons as possible candidates for higher office (12.13).

The transition is abrupt in form (cf. $5^{1} 6^{17}$ ), but the writer's mind passes naturally from the members of the community to those who act as officials and either as leaders or assistants regulate their worship and their life. In each case little is said of their duties, a knowledge of which is assumed; but, as in c. 2 , the whole stress is on character, on the moral and intellectual quali-

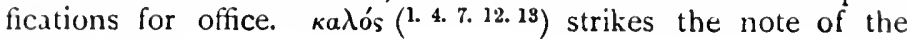
whole section.

Paraphrase. A third point on which $\mathrm{I}$ wish to lay stress is the character of those who hold any official position : and, first, for the leader of the worship, the bishop. You know the common saying:

"He who would play a leader's part

On noble lask has set his heart."

It is right, then, to wish for such a post; but such a noble task requires a character above reproach. So the bishop must not fall behind a high Christian morality in respect of marriage or sobriety, or self-control and dignity; and he must have special qualifications: he must be ready to welcome guests from other Churches, and able to teach in the assemblies: in dealing with m 2 mbers of the Church he must not be overbearing or hasty, but large-hearted, ready to make allowances, peace-loving: he must have no love of riches, as he has to control the finances: his power of ruling must be tested by his power of ruling his own household. Has that been a "noble task" with him? has he kept bis own children obedient to discipline with true dignity? if not, how will he be able to take charge of a Church of God's? Moreover, he must not be a recent convert; for, if so, his head may quickly be turned and the devil be able to bring accusations against him. Lastly, he must be well thought of by those outside the Christian body: otherwise he will easily cause scandal, and the devil will snare him to his ruin.

Then for assistants, deacons: they must have a character that inspires respect : their word must be trustworthy: they must not say one thing to one person, another to another: they must not be given to excess in wine: they must be above making money in unworthy ways: they must bold the truths of the gospel with a conscience free from stain. Yes, and like the leaders, they must be tested first, and only be admitted as deacons if no charge can be sustained against them.

Much the same has to be said about deaconesses: their 
character must inspire respect: they must not be gossips and scandal-mongers : they must be sober : entirely trustworthy.

There is another point about assistants (deacons), they may come to be leaders (bishops) : so in choosing them, see that they have the same qualifications about marriage and the discipline over their own families which are required for bishops. For those who have treated the diaconate as a noble task win for themselves another noble position and preach with full assurance in the faith which is in Christ Jesus. Cf. Tit $\mathbf{I}^{5 \cdot 9}$; St. Chrysostom, De Sacerdotio, ed. Nairn, pp. xxvi-xxviii.

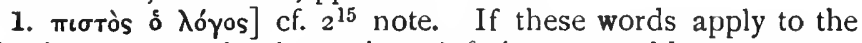
following paragraph, the variant $\dot{a} v \theta \rho \dot{\pi} \pi \iota v o s$ would seem more appropriate, the writer quoting a saying applicable to all overseership in human life ("allgemeinmenschlich," Wohlenberg) and applying it to the Christian Church. Deissmann (B.St., p. 230), shows that '́mírколоs was used as a pre-Christian religious title.

óé $\gamma \in \tau a \iota]$ "Aspires to," in no bad sense; but Clem. Rom. i. c. 44 shows how early a wrong ambition set in and was foreseen by the Apostles.

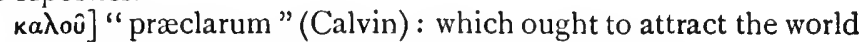
to Christ; and therefore difficult, $\chi \alpha \lambda \epsilon \pi \grave{\alpha} \tau \grave{a} \kappa \alpha \lambda \alpha$.

"̈prov] "negotium, non otium," Bengel, cf. 2 Ti $4^{5}$, I Th $5^{13}$

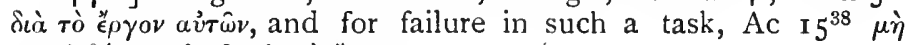

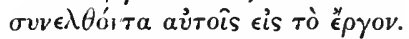

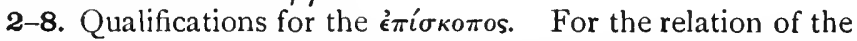

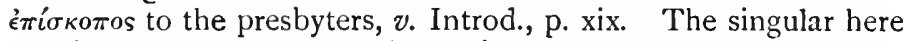
may imply that there was only one in the community, or it may be

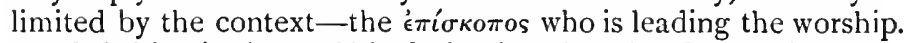
No definition is given of his duties, but the following are implied: (a) Presiding ( $\pi \rho \circ \hat{\imath} \sigma \tau \alpha \sigma \theta a \iota, \dot{\epsilon} \pi \iota \mu \epsilon \lambda \epsilon \hat{\imath} \sigma \theta \alpha \iota)$, i.e. (i) exercising discipline, cf. the analogy of the family ${ }^{5}$ ); (ii) (arising from the

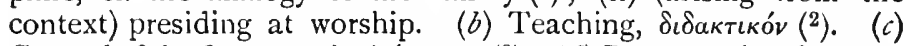

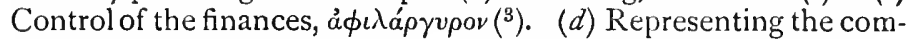
munity to Christians elsewhere $\left(\phi i \lambda o^{\prime} \xi \in v o v\left({ }^{2}\right)\right)$ and to the world outside ( 7 ).

These qualifications form guidance for "the scrutiny of candidates" who desire the office (Ramsay): they are partly the ordinary moral qualities which would be respected in a layman, and failure in which would imply censure; partly those which would be required for his special position. "To St. Paul the representative character of those who had oversight in the Ecclesia, their conspicuous embodiment of what the Ecclesia itself was meant to show itself, was more important than any acts or teachings by which their oversight could be exercised" (Hort). Hence it scarcely gives the ideal of a bishop, but the necessary

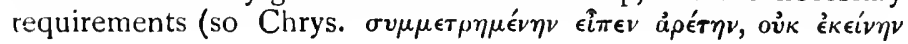


$\tau \grave{\eta} \nu \tilde{\alpha} \nu \omega, \tau \grave{\eta} \nu \dot{v} \psi \eta \lambda \dot{\eta} v)$. A comparison with Tit $\mathbf{1}^{5-9}$ shows how the list of moral qualifications was getting stereotyped: Bernard com. pares the recpuirements for the Stoic wise man, who was to be a married man $\left({ }^{2}\right)$, ürvoos $\left({ }^{6}\right)$, temperate in wine $\left({ }^{2}\right)$, and to combine

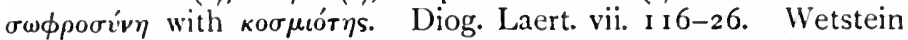
and Dibelius (q.v.) quote the close analogy of the requirements for the choice of a general, who was to be $\sigma \dot{\omega} \phi \rho o v \alpha, \dot{\epsilon}^{\prime} \gamma \rho \alpha \tau \hat{\eta}$,

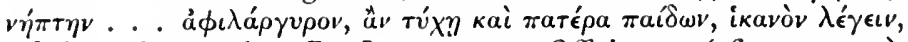

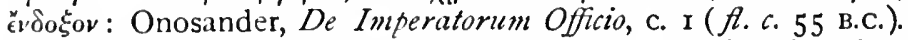
Either of such lists may have been known to our writer, but they are all probably independent.

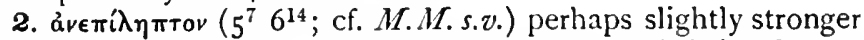

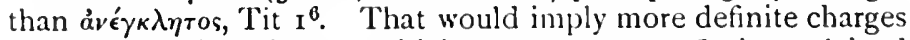
$\left(\kappa a \tau \eta \gamma o i^{\prime} a, i b.\right)$ : this, any criticism or censure. It is explained by the following words: Not liable to criticism as he would be if he failed in any of these qualities.

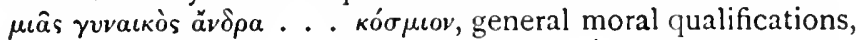
in relation to his own life: $\phi \iota \lambda \operatorname{có}_{\epsilon} \epsilon v^{\prime} \nu, \delta\llcorner\delta a \kappa \tau \iota \kappa o ́ v, ~ q u a l i f i c a t i o n s$ for his special office.

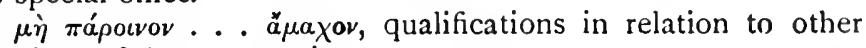
members of the community.

$\dot{\alpha} \phi \imath \lambda \alpha \gamma_{\gamma}$ pov, qualification in relation to the finance of the community.

rov̂ ióiov oǐkov, in relation to his own family.

$\mu \grave{\eta} v \epsilon о \phi v ́ \tau o v$, in relation to his standing in the community.

$\delta \in \hat{\imath} \delta \dot{\epsilon}$, in relation to the world outside.

$\mu \iota a ̂ s$ yuvaıkòs ă $\delta \delta \rho]$ In interpreting this difficult phrase, two facts guide us. (a) The standard is not the highest (v. supra); it must be something, failure in which would incur reproach; (b) but the standard is that of a Christian community; contrast $i$. It presupposes a knowledge of the teaching of Our Lord and of St. Paul.

(i) The phrase might imply that the bishop must be a married man (so Wordsworth, The Ministry of Grace, pp. 215-20; Lindsay, The Church and the Ministry, p. 145), and the writer might well prefer a man with the experience of the head of a family (cf. ${ }^{4}$ ) for the overseership of a church, and might wish to guard against any depreciation of marriage (cf. $4^{3}$ ); but to be unmarried would incur no reproach: such a requirement would be scarcely consistent with the teaching of Our Lord (Mt I $9^{12}$ ) and of St. Paul ( 1 Co $7^{7.8}$ ): so the writer is only thinking of the true character of a bishop, if married; as in ${ }^{4}$ he deals only with his relation to his children, if he has children.

(ii) It certainly implies - not a polygamist. Such a rule would still be neressary, as polygamy might still be found among Jews;

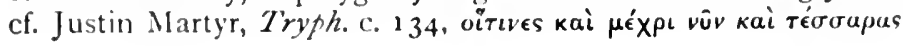




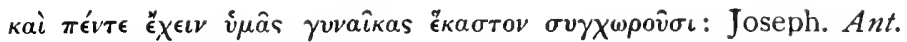

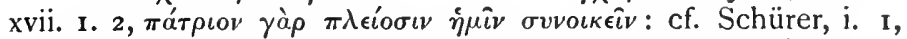
p. 455 note. Schechter, Documents of Jezvish Sectaries, i. I 7.

(iii) It also certainly implies "a faithful husband," married to one woman and loyal to her, having no mistress or concubine; $\mathrm{cf}$. Tertull. Apol. 46, "Christianus uxori soli suæ masculus nascitur."

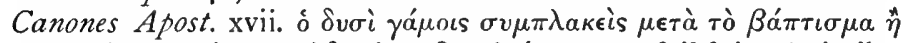

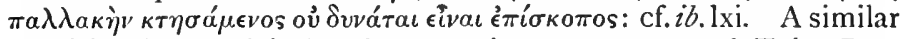
provision is found in heathen marriage contracts; cf. Tebt. Pap.

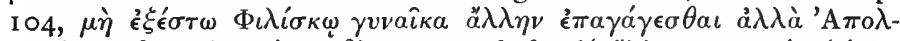

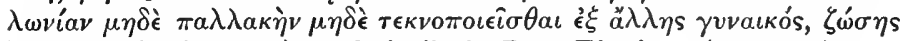
'A $\pi 0 \lambda \lambda \omega v i a s$ ( 92 B.C.), and similarly Pap. Eleph. I (310 B.C.).

(iv) It also implies, and was probably meant to imply, not divorcing one wife and marrying another. This would be a Christian rule, based both on Our Lord's teaching and on St. Paul's (cf. Hermas, $M$. iv. I, which forms a good commentary on this phrase), and very necessary in view of the laxity of divorce both among Jews (Schechter, u.s. ; Abrahams, Studies in Pharisaism, §9) and among heathen; cf. Friedländer (Eng. tr.), pp. 24243 ; Fowler, Social Life in Rome, c. 5. Dill, Roman Society from Nero to $M$. Aurelius, pp. $76-79$, though he points out that the heathen standard was rising: "The ideal of purity, both in men and women, in some circles was actually rising . . . there were not only the most spotless and high-minded women, there were also men with a rare conception of temperance and mutual love. ... Plutarch's ideal of marriage, at once severe and tender, would have satisfied St. Paul. . . . Seneca and Musonius, who lived through the reign of Nero, are equally peremptory in demanding a like continence from men and from women."

(v) Did it also imply, "not marrying a second time after his wife's death"? This is possible, but scarcely likely. No doubt the phrase led to this interpretation and was used to support it, and that by the end of the 2 nd century; cf. Tertull. ad Uxor. i. 7 ; Clem. Alex. Strom. iii. I 2 ; Origen, Hom. xvii. in Luc., and

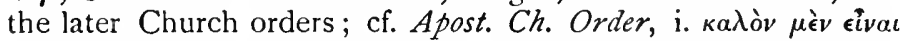

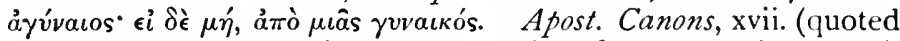

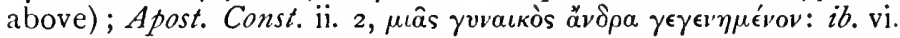
i 7. Test. Dom. N.J. Christi, c. 20 (where see Cooper-Maclean's note). There were also tendencies in the heathen world moving in the same direction. There was the feeling for the children of the first wife who might be harmed by the stepmother; cf. Eur. Alc. 30 I sqq.; Propert. iv. I I. 8I, and the law of Charondas forbidding such a second marriage, quoted in Diod. Sic. xii. 12 (Wetstein): there was also the natural devotion to a loved wife; cf. the Inscr. at Pisa (Orelli, ii. p. 517 , No. 4623), "conjug1 karissimæ ... cun quâ vixit annos xviii. sine querella, cujus 
desiderio juratus se post eam uxorem non habiturum"; cf. Bigg, The Church's Task, p. 102: "In the epitaphs two not uncommon words are virinius and virginia: they denote a husband who never had but the one wife, a wife who never had but the one husband." Such a feeling would be increased by the Christian thought of the eternal relation of husband and wife (cf. Chrys. on Tit $\mathrm{r}^{6}$ ); yet such a standard is always regarded as exceptional, and is too high for this context; and the later writers are influenced by a growing love for celibacy (áyúvaıos), which is certainly alien to this passage, and by the denunciation of second marriages in all cases (Athenag. Leg. 33), which is also alien to the Epistle, $5^{14}$; cf. Suicer, s.v. Siqupia. Dict. Christ. Ant., s.v. Marriage, p. 1097 and p. I103; and for a strong defence of the stricter view, The Library of the Fathers, Tertullian, vol. i. pp. $420-32$.

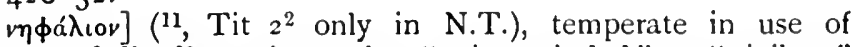
wine; cf. 8. $115^{23}$; perhaps also "sober-minded" or "vigilant" (äypvavov, Chrys., cf. Heb $13^{17}$, and Homer, Il. ii. 24, 25). Cf.

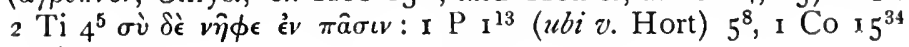
é $\kappa v \dot{\eta} \psi a \tau \epsilon$.

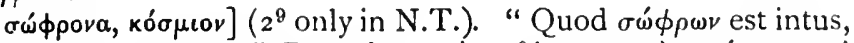

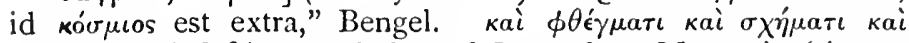

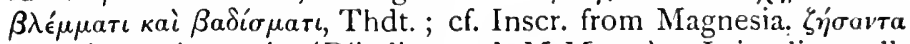

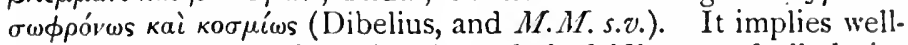
ordered demeanour, but also the orderly fulfilment of all duties and the ordering of the inner life from which these spring. Cf. Trench, Syn., p. 332. It is the quiet, orderly citizen, the antithesis of äтaктоs.

$\phi(\lambda o ́ \xi \epsilon \nu \vee v]$ The duty of individual Christians $\left(5^{10}\right)$ and of the whole Church ( $R$ o $2_{2}{ }^{13}$, I $\mathrm{P} 4^{9}, 3 \mathrm{Jn}^{5}$ ), with a special blessing

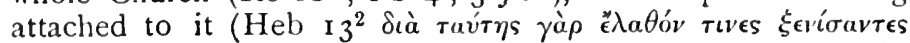

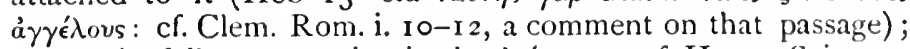
finding its fullest expression in the 'ंтiбколоs, cf. Herm. S. ix. 27,

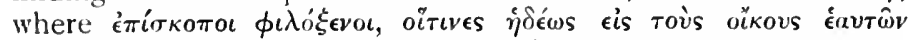

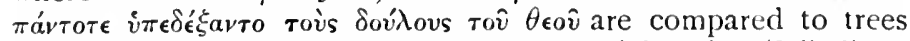
sheltering sheep, and singled out for special praise (Dibelius). For its importance, cf. Harnack, Exp. of Christ. I. ii. 3. ; Ramsay, Pauline Studies, pp. 382-86.

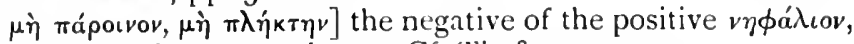
$\sigma \omega ́ \phi p o r ' a$, in relation to others. Cf. $\mathrm{Ti}^{8}{ }^{8}$ note.

$\dot{\epsilon} \pi\llcorner\epsilon \iota \hat{\eta}, \hat{a} \mu a \times 0 r]$ the mark of all Christians, ' $\mathrm{Ti} 3^{2}$, where see note.

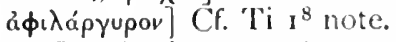

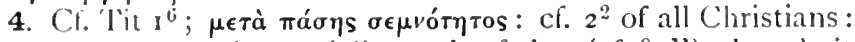
here the reference is specially to the father (cf. ${ }^{8} .{ }^{11}$ ), though it might include the effect on the whole household ( $\pi$ ár $\eta 5$ ).

5. For the analogy from the family to the Church, cf. Eph ${ }^{19}$ 


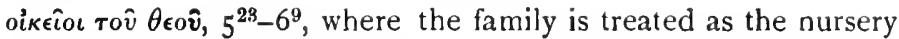
in which the virtues characteristic of the Church are trained. The analogy from the family to the State is common in classical writers ; cf. Sen. de Clem. i. 9., "quo hoc animo facis? ut ipse sis princeps? ... domum tuam tueri non potes," Tac. Agr. I9, and other instances in Vetstein and Dibelius.

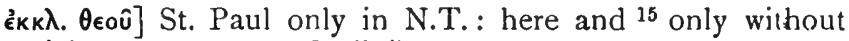
the article, " $a$ church of God's."

0. For later formulation of this rule, cf. Apostol. Canon lxxx.

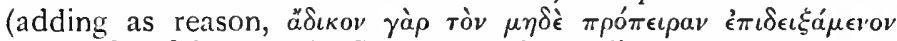

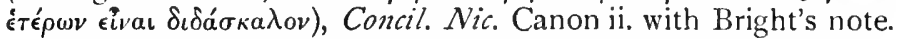

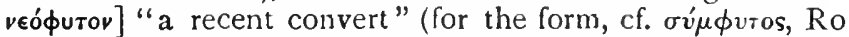
$6^{5}$; and for the metaphor, I Co $3^{6}$ ). The word is used literally in the LXX and Inscr. (Deissmann, Bible St. s.v.); as a simile,

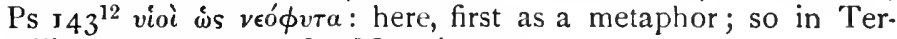
tullian, Prascr. 4 I, adv. Marc. i. 20.

$\left.\tau u \phi \omega \theta \in \epsilon^{\prime} s\right] 6^{4}, 2$ Ti $3^{4}$ only in N.T., from $\tau \hat{v} \phi o s$, smoke, with his head dazed and turned "in superbiam elatus," Vulg.; entêté. It combines the ideas of conceit and folly; he may behave arrogantly to others and teach foolishly. Wetstein aptly quotes the warning of Tiberius, "ne quis mobiles adolescentium animos præmaturis honorıbus ad superbiam extolleret," Tac. $A n n$. iv. I 7 . For the harm wrought by $\tau \hat{v} \phi o s$, cf. an interesting passage in

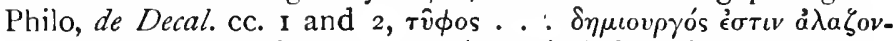

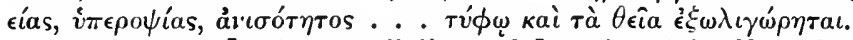

тoú Sıaßónou] The parallelism of 7 and 2 Ti $2^{26}$ makes it certain that this is "the devil," not (as Weiss) "some human accuser." But the analogy of $5^{14}$, Tit $2^{8}$ suggest that the devil is thought of as working through some human agent ; cf. Ecclus.

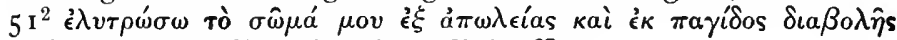
$\gamma \lambda \omega \sigma \sigma \eta s$, Prov $6{ }^{24}$, and perhaps Eph $4^{27}$.

крî́u roû Sıaß.] not (as Chrys. Pelag. Thdt. Calvin, Bengel) "the judgment passed on the devil," which is not parallel to ?, and would naturally be rò $\kappa p \hat{\imath} \mu \alpha$, but "some judgment which the devil, the slanderer, the setter at variance, the accuser of the brethren (Apoc. $12^{10}$, cf. Jude ${ }^{9}, 2 \mathrm{P}_{2}{ }^{11} \kappa$ cí $\left.\iota v\right)$, passes upon him. Such a novice is arrogant or foolish in teaching. The devil reproaches ( $\left.{ }^{7}\right)$. This is your humble Christian! this your learned teacher! The devil lays snares $\left({ }^{7}\right)$ to draw him on and to discredit the whole community. The man makes shipwreck of his faith by some moral $\left(1^{19}\right)$ or intellectual $\left(6^{21}\right)$ failure; he is handed over to Satan $\left(\mathrm{I}^{20}\right)$; and he passes judgment, perhaps some bodily infliction, upon him; cf. Joh I and 2 and Test. XII.

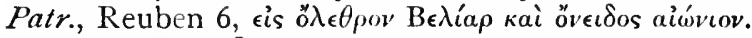

7. $\left.\tau \hat{\omega} \nu "{ }^{\prime \prime} \xi \omega \theta \epsilon v\right]$ For St. Paul s care for the opinion outside the Church, cf. I $\mathrm{Th}_{4}^{12}$, I $\mathrm{Co}{ }_{10}^{32}, \mathrm{Col} 4^{5}$. 


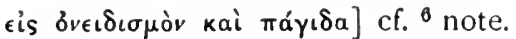

8-10. Deacons] For the earlier use of the word, cf. Hort, The Christian Ecclesia, pp. 198-211; a recognized title for an office alr ady existing. No definition of duties is given. The rame implies service-assistant ministration-perhaps in the Church services, certainly in administering charity and attending to the needs of the poorer members; and it is implied that they would naturally pass to higher office in the Church. The qualifications are partly central Christian virtues ( $\sigma \epsilon \mu v o v$ s), partly those needed for their office as they moved from house to house $(\mu \grave{\eta}$

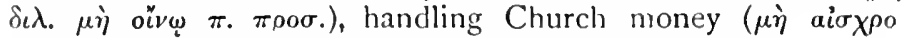

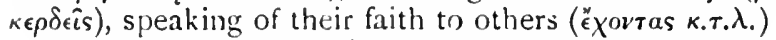

For similar qualifications, cf. Polyc. ad Phil. 5, perhaps based on this passage.

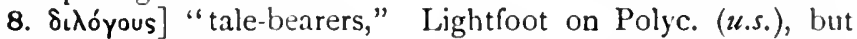
prob.ıbly "double-tongued," "ad alios alia loquentes" (Bengel);

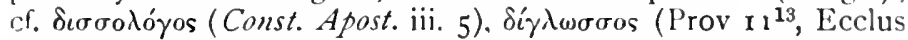

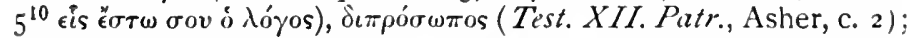
"the parion of our parish, Mr. Two-Tongues" (Pilgrim's Pro.

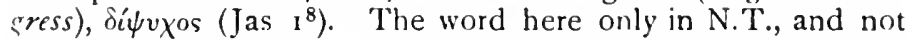
elsewhere in this sense. For the thought, cf. Test. XII. Patr., Benj.

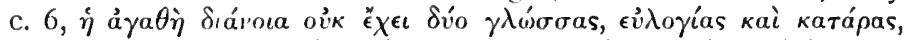

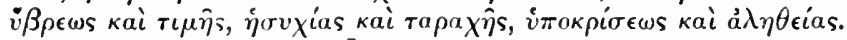

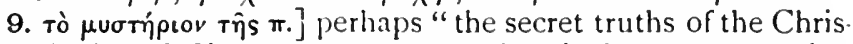
tian faith"; cf. I6, lay,ng stress on doctrinal correctness, but more probably, as there is no duty of teaching implied, holding their own fatth, the secret of their allegiance to Christ, secure under the protection of a good conscience, "a true inward religion and a true inward morality" (Hort., u.s.). The stress is on $\dot{\epsilon}^{\prime} \kappa a \theta$. $\sigma v v \epsilon \iota \delta \dot{\eta} \sigma \epsilon \iota$, the casket in which the jewel is to be kept ; cf. $1^{19}$ note.

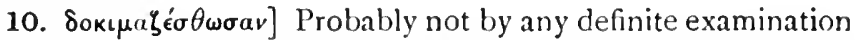
or ly a time of probation (Ramsay), but only in the same way

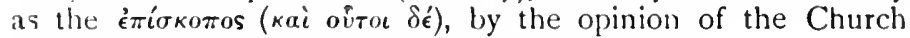
judging his fitness by the standard just laid down.

11. yuvaikas] From the context and from the parallelism between the qualities required for them and for the deacons

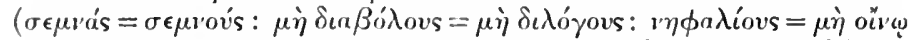

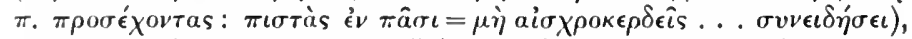
these must be "deaconesses" (not "wives of deacons"), women who help ; cf. Ro $16^{1}$; Pliny, E.p.x. 96 (written A.D. I 12 ), "ancillis quxe ministre dicebantur." Their duties in later times are defined as instructing and attending at the bajtism of female catechumens, of looking after them at the services and taking messages from the bishops to them; cf. Dict. Christ. Antiq. s.7'; Nic. Canon xix., with Bright's note. Apost. Const. ii. 26 , iii. i5, eis 


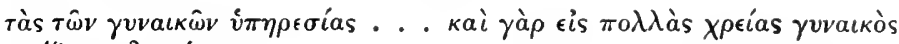

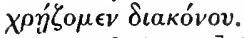

12. Sı́́kovol] The writer returns to deacons from a new point

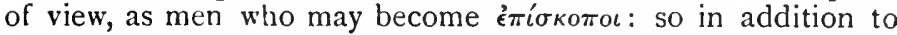
what they needed as deacons they must have the two external relations-to wi'e and children-which were required in the

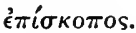

13. $\beta \alpha \theta \mu o ́ v$ (here only in N.T.), lit. "a step" (so in LXX, I S $5^{5}$, Ecclus $6^{36}, 2 \mathrm{~K} 20^{9}$ ); then "a standing," "position". This may be thought of as-

(a) Moral: a vantage ground for influence, analogous to

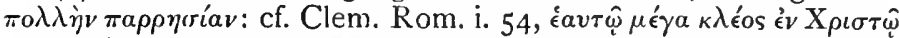

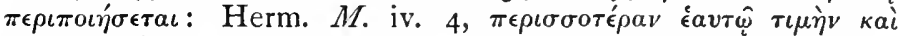

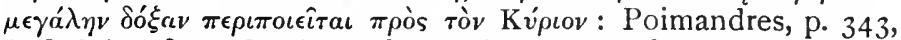

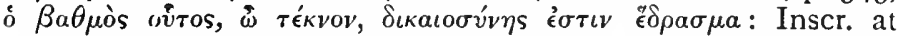

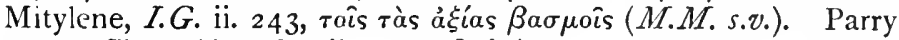

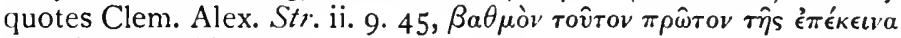

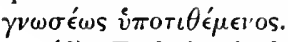

(b) Ecclesiastical: a higher grade, an honourable rank; cf.

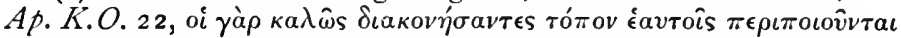

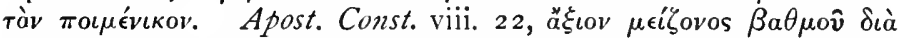

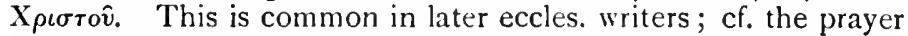

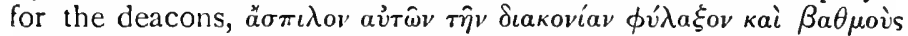
ả $\gamma \alpha \theta$ ò̀s $\pi \epsilon \rho \iota \pi \circ i ́ \eta \sigma \alpha \iota$, "Lit. of S. James," Brightman, E. and W. L.,

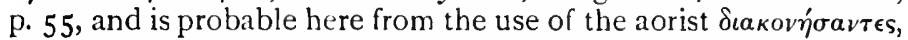

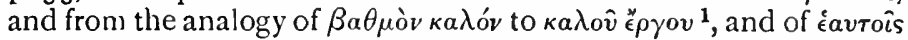
$\pi \epsilon \rho \iota \pi \circ \iota 0 \hat{v} v \tau a \iota$ to $\epsilon \pi \iota \theta v \mu \epsilon \hat{\imath}$. But such eccles. promotion will include all that was impled in $(a)$. It is used of promotion in the army ; cf. Harrison, p. 165, who quotes from Hadriani Sententice,

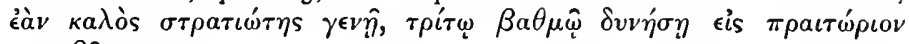
$\mu \in \tau \alpha \beta \hat{\eta} v a \iota$.

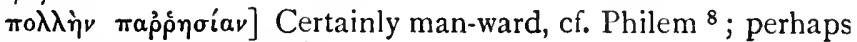
also God-ward, cf. Eph $3^{12}$.

With the whole verse contrast Herm. S. ix. 25, where dishonest deacons are compared to reptiles and wild beasts that

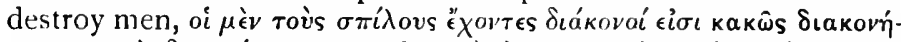

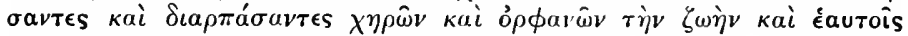

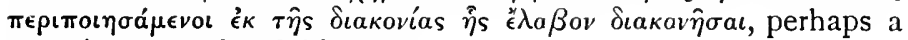
conscious parody of this verse.

\section{4-16. The Secret of True Christian Character.}

Paraphrase. I hope to come to you soon and strengthen your hands by my presence; but in case I should be delayed, I write at once that you may know what is the true Christian life, the true relation of one with another in God's own family, for it 
is a Church belonging to God Himself, the living source of all life; and its task is to hold up the truth for the whole world to see and to give it a firm support in the lives of its members. And confessedly the secret of a true religious life is very important; for it centres in a personal relation to a Living Person: to one of whom we sing in our hymns that He was-

"In flesh unveiled to mortals' sight,

Kept righteous by the Spirit's might,

While angels watched him from the sky:

His heralds sped from shore to shore,

And men believed, the wide world o'er,

When he in glory passed on high."

This section primarily gives the reason for the regulations in the preceding chapters, especially cc. 2 and 3 ; but it also leads on to the warning against false teaching and the advice about Timothy's teaching which follows. It thus becomes the very heart of the Epistle; it should be compared with similar doctrinal conclusions in $x^{15} 2^{3-5} 6^{13-16}$, Tit $2^{12-14} 3^{5-7}$. But this goes deeper than all in its picture of the Incarnate and Glorified Christ as the centre of the true life of the whole world, cf. $2 \mathrm{Ti}^{8}{ }^{8}$. It is the poetic expression of Gal $2^{20} \zeta \hat{\eta}$ ćv émoi X X

14. тaûta] i.e. mainly cc. 2 and 3 (with their constant stress on true character, on the knowledge of truth $\left(2^{4.7} 3^{9.13}\right)$, and on God's family); but it may include the whole letter.

Ė $\left.\lambda \pi i \zeta_{\omega \nu} \dot{e} \lambda \theta \in \hat{i} v\right]$ Not "although I hope," but "hoping." I write and hope to cone and strengthen your hands by my personal

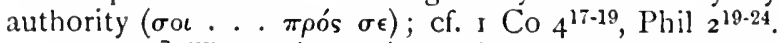

év TáX€ı] The variant ráxıov will mean much the same, as its comparative sense was dying out; cf. Jn I $3^{27}$, Heb I $3^{23}$; cf. $\beta \epsilon ́ \lambda \tau \iota$, II I ${ }^{18} ; \sigma \pi 0 v \delta \alpha \iota^{18} \tau \rho o v, v . l .$, II I ${ }^{17}$.

15. $\pi \hat{\omega} s \delta \epsilon \hat{\imath}$ ] Picking up $3^{2.7}$.

év oik $\omega$ house," but "God's family"; cf. 'T't $\mathrm{I}^{11}, 2 \mathrm{Ti}{ }_{1}^{16}$, and Eph $2^{19}$

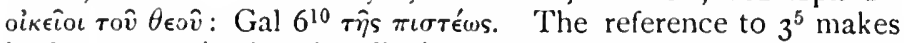
it almost certain that the allusion is not to the universal family, to the Church as a whole, but to the special community at Ephesus.

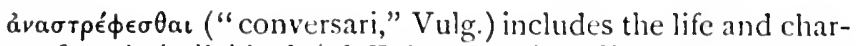
acter of each individual (cr. Eph $2^{3}$, Heb ${ }^{13} 3^{13}$, and $a v^{\prime} \alpha \sigma \tau \rho o \phi \eta$, Gal $\mathrm{I}^{13}$, Jas $3^{13}$, and instances from papyri in M.M. s.v.); but also the intercourse of each nember with other members, of men with "omen (c. 2), of parents with children, of ministers with those to whom they minister (c. 3 ); cf. Hort on I P I ${ }^{7}$. "He wishes 'fimothy to have before him an outline of the relation which must exist between the various parts of a congregation or houschold of God" (Ramsay). 
The subject of $\alpha \dot{\alpha} \nu \sigma \tau \rho \epsilon \in$. might be $\sigma \epsilon$ (which is found in a few MSS and Fathers), "how you ought to behave," as the oikóvoros in the household, but the general character of cc. 2-3 makes it almost certain that it should be wider, "how men ought to behave," "that you may know the right relation of class to class." $4^{12}$ shows that it will include Timothy himself as well as those to whom he is to be a model.

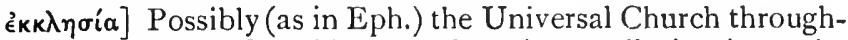
out the world; but $3^{5}$ decides that the primary allusion is to the Church at Ephesus as a separate congregation, though thought of as part of the larger whole; cf. Bengel, "Ecclesiam innuit universalem, non universe, sed quatenus pars ejus tum erat Ephesi, commissa Timotheo," and Hort, The Christian Ecclesia, pp. $172-75$. This increases the dignity attached to each Christian Church and therefore a fortiori to the whole Ecclesia which incorporates them.

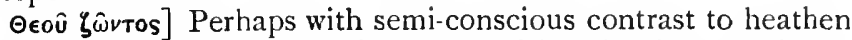
gods, cf. I Th $\mathbf{I}^{9}, 2$ Co $6^{16}$; but emphasizing the thought that a God of life can give life and make such intercourse possible, cf. $4^{10} 6^{13}$, and perhaps the thought that $\mathrm{He}$ is alive to punish those who fail to live the true life, cf. Heb $10^{31}$ : so " a contrast with the true God made practically a dead Deity by a lifeless and rigid form of religion" (Hort, u.s.).

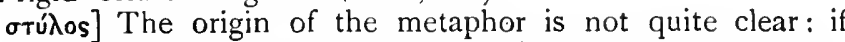
orv́dos is used of the Universal Church, it would be drawn from some one pillar standing alone and holding up to view a statue (such as was afterwards "Pompey's pillar" at Alexandria). If, however, it is applied to a local church or an individual ( $v$. next note), the thought will be of one of a row of pillars which support and give strength to the whole fabric, like one of the many pillars in the temple of Artemis at Ephesus: there will be no sharp distinction between it and E⿱㇒㠯幺a $\boldsymbol{i}_{\omega \mu \alpha}$. This is the more probable, the combination of the two words being common. According to Lightfoot (Horce Hebr., The Temple, c. 22), it was applied to the great Sanhedrin by the Jews; by $R$. Levi, to the reference to the Exodus in the Paschal precepts, "quia fundamentum id magnum sit et columna valida legis ac religionis Judaicæ" (Bengel).

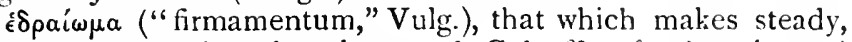
stay, buttress, rather than base; cf. Col ${ }^{23} \tau \epsilon \theta \epsilon \mu \epsilon \lambda \iota \omega \mu \epsilon^{\prime} v_{0 \iota}$ кui

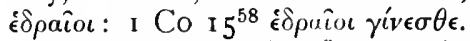

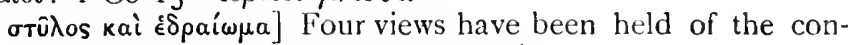
struction-(i) In apposition with é $\kappa \kappa \lambda \eta \eta \sigma i ́ a$.

(ii) In apposition with the nominative of $\epsilon i \delta$ iss.

(iii) In loose ungrammatical apposition with $\theta \epsilon \hat{v}$ (Holtzmann)

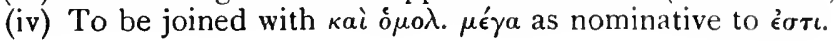


Of these (iii) and (iv) may be put aside. (iii) is unnecessarily artificial, and gives an inadequate description of the living God. (iv) though defended by Bengel, leads to an anticlimax, $\sigma \tau$. кai é $\delta$. каi $\mu \epsilon \gamma \alpha$, and is tautological, "the secret of godliness" is not the support of the truth, but the truth itself. In favour of (ii) it is to be said that $\sigma \tau \hat{v} \lambda$ os is used generally of individuals in the N.T. (Gal $2^{9}$, Rev $3^{12}$ ): that the combination of the same or similar words is also so used (cf. Eus. H.E. v. I of Attalus,

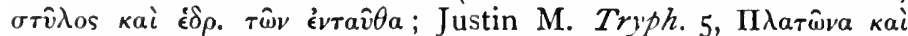

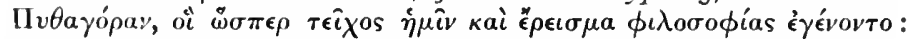

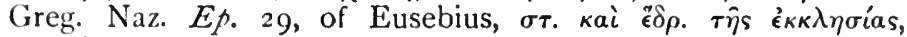

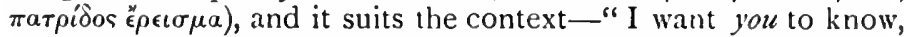
... because you are in position to uphold and support the truth," cf. ${ }^{18} 6^{20}$. Yet the stress of the preceding chapters has been more on what the Church than on what Timothy is to be, and this is decisive for (i). Each local Church has it in its power to support and strengthen the truth by its witness to the faith and by the lives of its members. A very full note on the usage of the words will be found in Suicer, Thesaurus, s.v. orî̀os.

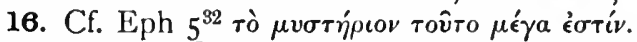

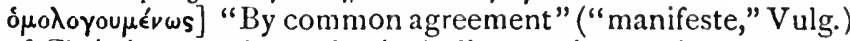
i.e. of Christians, perhaps also including the impression made on the pagan world around ; or perhaps "by common profession" ("omnium confessione," Ambros.), hinting that the following words come from some Church hymn, and so equivalent to o $\mu o \lambda o \gamma o v \tilde{\mu} \epsilon \nu$ is found in $\mathrm{D}^{*} \mathbb{S}$ (pal).

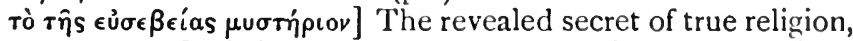
the mystery of Christianity, the Person of Christ: cf. Col ${ }^{27} \tau \dot{o}$

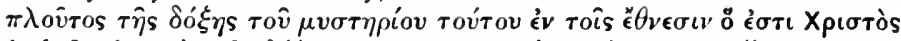
$\dot{\epsilon} \nu \dot{v} \mu \hat{\imath} \nu, \dot{\eta} \dot{\epsilon} \lambda \pi \hat{\imath} \boldsymbol{\tau} \hat{\eta} s \delta \dot{\delta} \xi \eta \varsigma$. The phrase is perhaps a deliberate con-

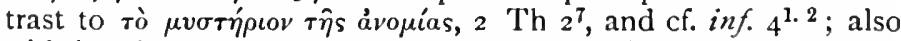
with implied contrast both to Judaism, cf. $1^{8-11}$ and Ep. Diogn.

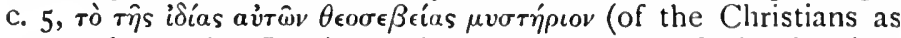
opposed to the Jews); and to the secrets of the heathen

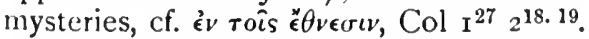

$\tau \hat{\eta} s \in \dot{U} \sigma \epsilon \beta \epsilon$ ías may perhaps include the thought of doctrine as well as of life, "Christianity," as it in later ecclesiastical Greek became the equivalent to orthodoxy : but the context here and the use of it as applied to the life of all Christians $\left(2^{2}\right)$ and of Timothy himself $\left(4^{7.8}\right)$, shows that the main stress is here on

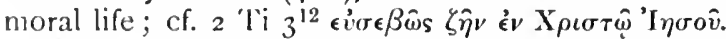

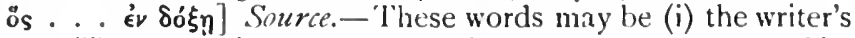
own, or (ii) a quotation. The latter is more likely because of its

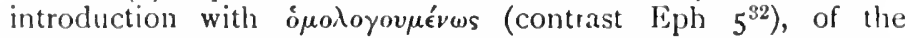
rhythmical form, of the use of words not found elsewhere in this

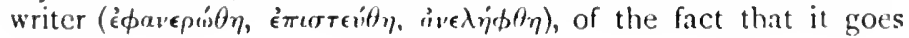


beyond the statements required by the context, and of the writer's fondness for quotation. If this is so, it will be from some well-known Christian hymn (cf. Eph $5^{19}$ ), possibly from the same hymn as that quoted in Eph $5^{14}$, in which case $\dot{o}$ X $\rho \tau \tau$ ó will supply the antecedent to oss. It implies a wide preaching of Christianity, but such as might fall within St. Paul's lifetime; cf. Col $1^{6} \dot{\epsilon}^{\prime} \nu \pi \alpha^{\prime} \nu \tau \iota \tau \hat{\omega} \kappa o ́ \sigma \mu \omega$. There are reminiscences of it in $E p$.

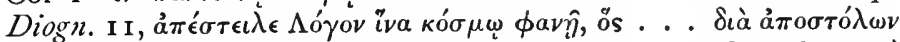

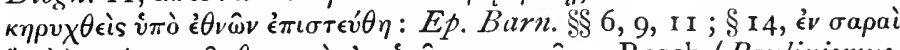

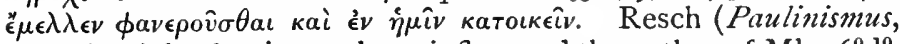
p. 397) thinks that it may have influenced the author of $\mathrm{Mk} \mathbf{1} 6^{9-19}$.

Structure. The arrangement is uncertain: it may be six parallel lines in groups of two, but this gives no clear correspondence of thought in the group: more probably it represents two stanzas of three lines, which balance each other, contrasting the Incarnate Lord with the Ascended Lord.

(i) The Life of the Incarnate-

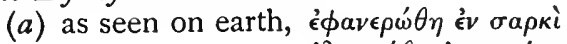
$\epsilon^{\epsilon} \delta \epsilon \alpha \iota \omega \dot{\theta} \theta \eta \dot{\epsilon} \nu \pi v \epsilon \dot{\mu} \mu \alpha \tau \iota$.

(b) as watched from heaven, $\ddot{\omega} \phi \theta_{\eta} \dot{a} \gamma \gamma \hat{\boldsymbol{\epsilon}} \mathbf{\lambda}$ oเs.

(ii) The Life of the Ascended Lord-

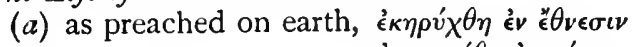
$\dot{\epsilon} \pi \iota \sigma \tau \epsilon \dot{v} \theta \eta \dot{\epsilon} v \kappa o ́ \sigma \mu \omega$.

(b) as lived in heaven, $\quad \dot{a} v \in \lambda \dot{\eta} \phi \theta \eta \dot{\epsilon}^{\prime} v \delta^{\prime} \dot{\xi}_{\eta} \eta$

The main thought, then, is that one who has really lived a perfect human life on earth has a message for the whole world, and lives to give his righteouness to all; cf. I $^{11} \tau \hat{\eta} s \quad \delta o ́ \xi \eta s: 2^{4-7}$ $\dot{v} \pi \grave{\epsilon} \rho \pi \dot{a} v \tau \omega \nu \ldots . . \dot{\epsilon} \theta v \hat{\omega} \nu$.

os] What is the antecedent? (a) \& X X in $\epsilon \dot{v} \sigma \epsilon \beta$. $\mu v \sigma \tau$ t ous verse of the hymn; cf. Eph $5^{14}$. It can scarcely be $\theta$ cós, to which $\epsilon_{\delta} \delta \kappa a i \omega \theta \eta$ would not be suitable, but might be $\theta \epsilon o \hat{v}$ viós; cf. Ep. Barn. c. 5, which seems reminiscent of the passage,

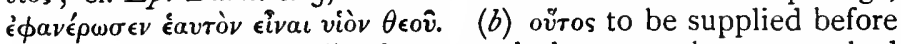
line 4. He who so lived on earth has now been preached throughout the world (von Soden); but this lays almost too much stress on the last stanza, and is less suited to poetic style.

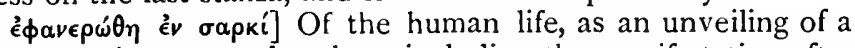
previous existence, and perhaps including the manifestation after the Resurrection; but the stress on $\sigma \alpha \alpha^{\prime} \xi \xi$ is on its reakness, in the weak flesh that we share; cf. Ro $\delta^{3}$, Gal $2^{20}$. Neither word is used of Christ in the Pastorals: the first is Johannine, the second, both Johannine and Pauline.

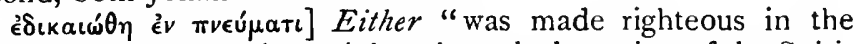
spiritual sphere," was kept sinless through the action of the Spirit

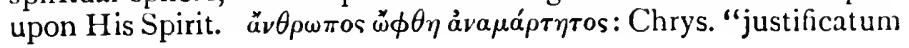


et immaculatum factum virtute sancti spiritus"; Theod.-Mops.;

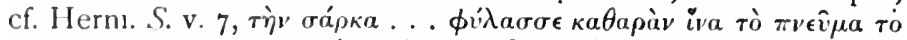

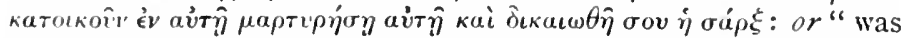
justilied" in His claims to be the Christ in virtue of the Spirit which dwelt in Him, enabling Him to cast out devils (cf. Mt I $2^{23}$ ), to con-

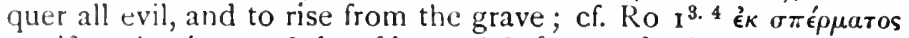

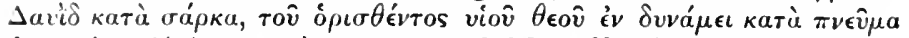

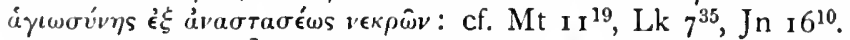

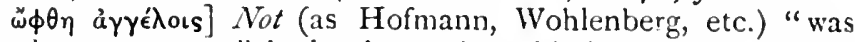
seen by messengers," i.e. by those who told the message of His

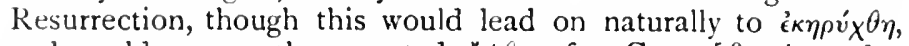
and would sum up the repeated $\ddot{\omega} \phi \theta \eta$ of I Co $15^{5-8}$ : the reference to the Resurrection, though included in $\epsilon^{\prime} \delta \iota^{\prime} \iota \omega \dot{\omega} \theta \eta$, is scarcely explicit enough for this : but "was seen by angels," who watched the earthly life, cf. $\mathrm{Lk}^{13}, \mathrm{Mk}^{13}, \mathrm{Jn}_{\mathrm{I}}{ }^{51}, \mathrm{Lk}^{2} 4^{23}$, and still watch $\mathrm{H}$ is working from Heaven, $\mathrm{Eph} 3^{10}$, $1 \mathrm{P} \mathrm{I}^{12}$. Dibelius quotes the Ascension of Isaiah, c. I I, "all the angels of the firmament and Satan saw Him and adored Him."

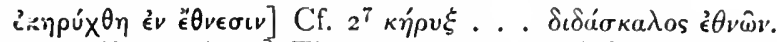

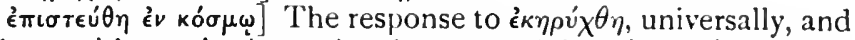
perhaps with emphasis on the character of the kó $\sigma \mu o s$, in a world full of sinners (cf. $\mathrm{r}^{15}$ ) which needed reconciliation ( $2 \mathrm{Co}_{5}{ }^{19}$ ).

ảve $\lambda_{\eta} \phi \theta \eta$ (Acts $\mathrm{r}^{2.11 .22}$, Ps -Sol $4^{20}$ with Ryle and James' note : Apoc. Baruch, ed. Charles, p. 73) '́v $\delta \delta^{\prime} \xi \eta$ in an atmosphere of glory in which He remains, and communicates His glory to men; cf. I $^{11}$ note.

For a somewhat similar reminiscence of a hymn about Christ's Life, cf. I P $3^{18-22}$.

iv. 1-5. Warning against false teaching.

Paraphrase. Yet, though each church has to uphold the truth, and though it knows the secret of the true human life, inspired prophets have given us clear warning that, in after days, some Christians will fall away from the true faith: they will pay heed to evil misleading spirits, to doctrines inspired by heathen deities, embodied in the false teaching of insincere men-men whose own conscience bears the brand of $\sin$ upon it, men who teach others that it is a duty not to marry, and a duty to abstain from certain kinds of food. Yet it was God who created those foods, and created them that those who have accepted Christ and come to know His full teaching might enjoy the mith thankfulness. For every created thing has the Creator's stamp of excellence upon it, and there is none that need be cast aside, if only it is accepted with a grateful heart, for then it becomes consecrated by the 1)rone blessing and our responsive prayer. Cf. Mt $24^{11}$, Acts $20^{24.30}, 2^{\text {I'h }} 2^{1-12}, 2 \mathrm{Ti} .3^{1-5}$, 'Tit $1^{14-16}$, and notice how in the 
address to the elders at Ephesus the warning against "grievous wolves" follows directly on the duty of feeding the flock and on the mention of "the Church of God."

The false teaching referred to. The prohibition of marriage and of certain foods finds an exact analogy in the Gnosticism of the 2 nd century; cf. Iren. Har. i. 28 , of the Encratites, $\dot{\alpha} \gamma \alpha \mu \mu^{\prime} \alpha \nu$

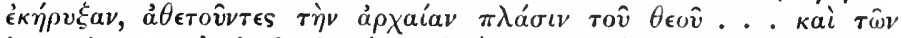

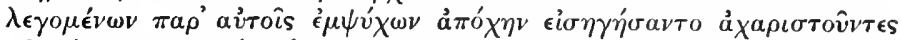

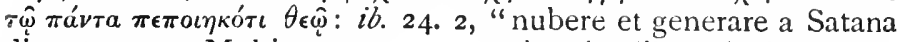
dicunt esse. Multi autem . . . et ab animalibus abstinent, per fictam hujusmodi continentiam seducentes multos" (both of which passages seem reminiscent of this place). Cf. the Acts of Paul and Thekla, c. 12. If the Epistle is not genuine, this is doubtless the reference. But there is no allusion here to the Gnostic central doctrine of an inferior Demiurge (cf. ${ }^{3}$ note), and there is nothing that goes beyond the teaching already denounced in Ro. 14 , Col $2^{10-23}$, Heb $13^{4.9}$. We may therefore trace it possibly to a Judaism

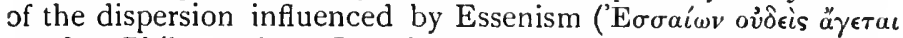
ruvaîka, Philo, p. 633; Josephus, B.J. ii. 8; cf. Ep. Diogn. c. 4), or perhaps more probably (cf. $\delta a \iota \mu o v i \omega \nu$ ) to Oriental tendencies which developed into Gnosticism. In such a syncretistic city as Ephesus there is no need to assume only one set of false teaching.

(2n the other hand, the allusions are too definite for it to be merely " an apologetic vade-mecum for all anti-Gnostic controversy" (Dibelius).

1. $\delta \epsilon]$ With slight antithesis to $3^{15}$ and the substance of $3^{16}$.

Tò $\pi v \in \hat{u} \mu a]$ The Spirit of the Lord speaking through some prophet, possibly the writer himself, "sibi," Ambros. ; cf. Ac $20^{29}$, but vide next note.

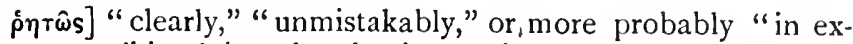
press terms," implying that he is quoting a prophecy (cf. Justin Martyr, Apol. i. 63). If so, the utterance of the Spirit will not have been made to the writer himself, but he is quoting that of some other Christian prophet. The person is ignored: the fact of his inspiration emphasized; cf. Charles, Revelation, i. p. cix.

év úotépoıs kaıpoîs] "In later days," "at some later crisis" (the plural not being pressed; cf. katpois idioıs, Tit $\mathrm{I}^{2}$ note); cf.

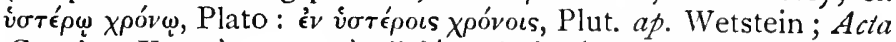

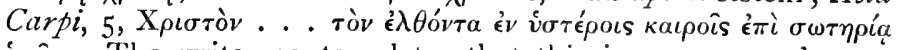
$\dot{\eta} \mu \hat{\omega} v$. The writer contemplates that this is a present danger, cf. 6-11 : hence we may paraphrase, "there is a past prophecy about a later crisis, which is now being fulfilled"; cf. I Jn $4^{1-3}$.

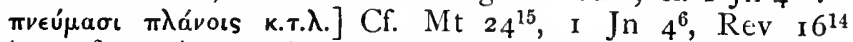

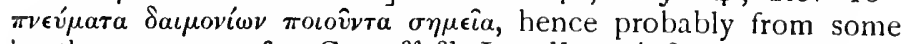

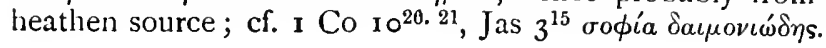


¿́v ímoxpí⿴\zh11ા] Insincere, because their own lives are inconsistent ; cf. MIt $23^{4}$, Ro $2^{17-23}$.

The clause is connected ciosely with $\delta \delta \delta a \sigma \kappa a \lambda$ ia s, teaching embodied in insincere utterances of lying teachers.

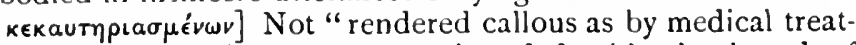
ment," cf. Eph $4{ }^{19}$, but rather "branded with the brand of slavery to their true master Satan," cf. 2 Ti $2^{26}$, and contrast

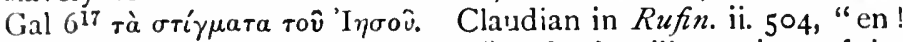
pectus inustæ Deformant maculæ," and other illustrations of the metaphor in Wetstein here and on Gal. l.c.

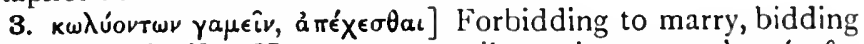
to abstain; cf. $2^{12}$. Hert unnecessarily conjectures кai $\gamma \in \dot{v} \epsilon \sigma \theta a \iota$ or $\ddot{\eta} \ddot{a} \pi \tau \epsilon \sigma \theta a \iota$, W.-H. note ad loc.

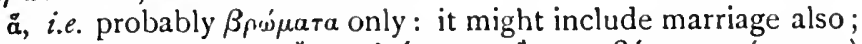

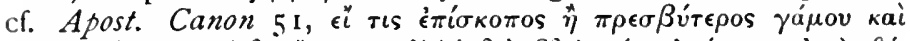

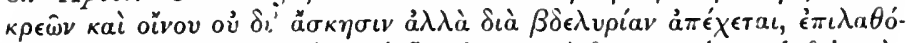

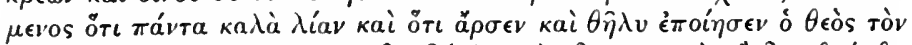

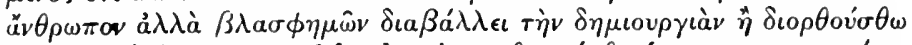

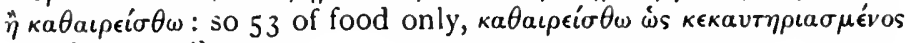

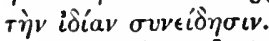

Tois mírors] those who have accepted the gospel-so not for the Jews, n whom the Levitical law was still binding: $k a i$ ' $\pi \epsilon \gamma^{\nu}$. Tे̀v ả $\eta^{\prime} \theta_{\text {ela }}$ - so not for weak Christians who have till late been used to idol worship or scruple about eating meat; cf. I Co

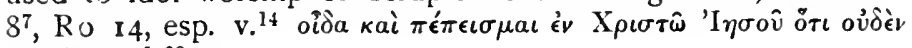
Kolvo' ${ }^{2}$, and ${ }^{23}$.

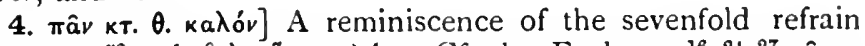

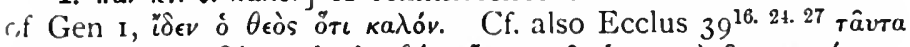

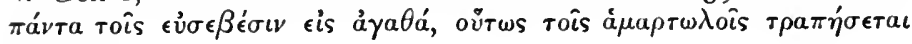
tis кaкá.

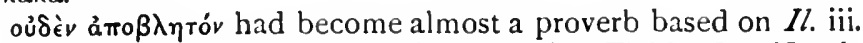

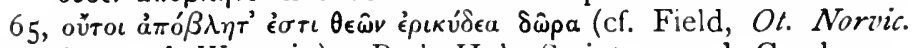
ad loc., and Wetstein). Both Holy Scripture and Greek proverbial wisdom condemn these teachers.

$\lambda a \mu \beta a ́ v o \mu \epsilon v o v]$ If taken as a gift-not treated as a right-and with gratitude. The divine word is constantly $\lambda a^{\prime} \beta \epsilon \tau \epsilon$, фú $\gamma \epsilon \tau \epsilon$ (Mt $26^{26}$ ).

áyı́ábral] It becomes holy to the eater; not that it was unclean in itself, but that his scruples or thanklessness might make it so to him. Possibly there is the further thought, it is protected from

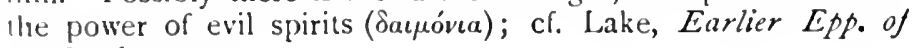
St. Pranl, p. 195.

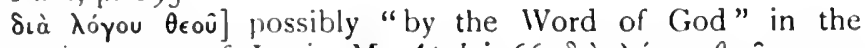

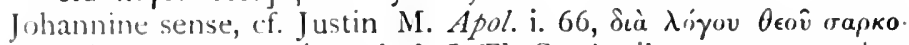

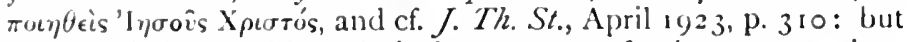
more probably, as this technical sense seems foreign to our writer. 
"through God's utterance," "with God's blessing upon it," referring directly to Gen I. "God said," peihaps more exactly to the word implied in $\pi \hat{\alpha} v \kappa$ кi $\sigma \mu \alpha \theta \epsilon o \hat{v} \kappa u \lambda o ́ v$. But this word is thought of as taken up in some word of Scripture used from meal to meal ( $\dot{\alpha} \gamma \iota \alpha^{\prime} \zeta \epsilon \tau \alpha \iota$, not $\left.\dot{\eta} \gamma \dot{i} \alpha \sigma \tau \alpha \iota\right)$ as grace: e.g. Ps $24^{1} \tau o \hat{v}$

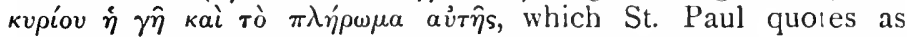
sanctioning the eating of all food sold in the market ( 1 Co $\left.10^{26}\right)$,

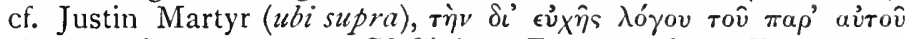

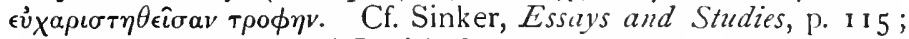
and for the influence of Jewish forms of grace upon the blessing of the bread and wine and other offerings in the Eucharist, von der Goltz, Tischgebete und Abendmahlsgebete. T. und U., N.F. xiv.,

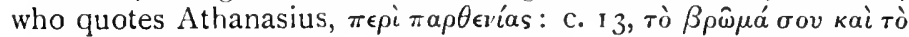

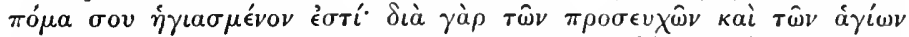

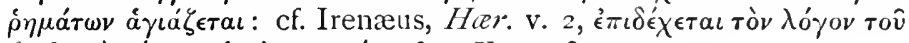

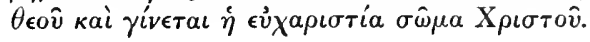

iv. 6-vi. 2. Personal advice to 'Timothy, as to $(a)$ his teaching and life as the chief officer of the Church $\left(4^{6 \cdot 16}\right) ;(b)$ his conduct to various classes of the members of the Church $\left(5^{1}-6^{2}\right)$.

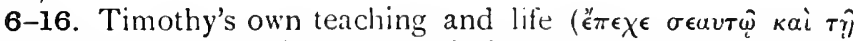
$\delta \ell \delta \sigma \sigma \kappa a \lambda i^{\prime}{ }^{16}$ sums up the paragraph, but the two parts are not kept distinct).

Paraphrase. Put these foundation truths before the brethren, and you will be a true servant of Christ Jesus, keeping your own soul trained by the precepts of the faith and of the true teaching which you have accepted and taught so faithfully until now. But as for those irreligious and old wives' fables which are so prevalent at Ephesus, have nothing to do with them at all.

Yet there is a training which you will need, and now you must be your own trainer, the training which helps towards a holy life. The bodily training of the athlete has some little value, but a holy life is valuable in every respect :

"To it God's promise standeth sure Of life that ever shall endure."

That saying is quite true and worthy of whole-hearted acceptance : for it is to win life that we spend our days in toil and take part in the spiritual contest, for our hopes have been set on a God of Life, on one who is a Saviour of all men, but, in the deepest sense, of those who put faith in Him. Hand on these truths from me and enforce them in your own teaching.

So teach and so live that no one shall slight you for your youth; nay, rather show yourself a model of what believers should be both in speech and in your dealings with others- 
lovins, trustworthy; pure. Until I can reach you, do you superintend the reading of the Scriptures, the sermons and the instructions given at the meetings. Do not neglect the divine gift which is in you, remembering that it was a gift from God, given after the guidance of prophets, and confirmed by the whole body of presbyters when they laid their hands on your head. Think carefully of these duties; throw yourself heart and soul into them, that everyone may note your constant growth. Keep careful watch over your own life and the teaching that you give: persevere in all these tasks. So will you work out your own salvation and that of those who hear you.

The keynotes of the paragraph are: (i) Doctrinal. yvuvaria,

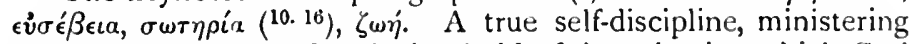
to holiness of life, and so laying hold of the salvation which God offers to all, and which is true life. (ii) Personal. Timothy's

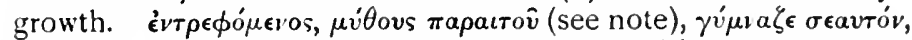

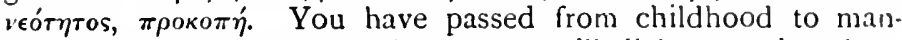
hood, when you can so act that no one will slight you; but there must still be growth, still constant self-discipline.

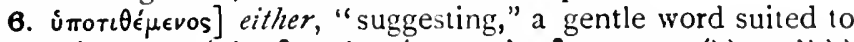

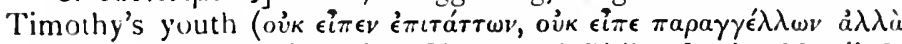

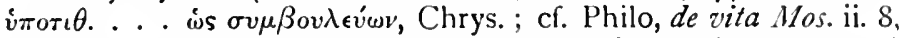

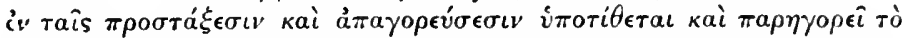
$\pi \lambda \epsilon^{\prime} \nu^{\hat{\eta}} \kappa \epsilon \lambda \epsilon v^{\prime} \iota$ ) ; or "supplying," as a foundation for their faith, the metaphor of building $\left(3^{15}\right)$ being still in his mind; cf. Jude ${ }^{20}$.

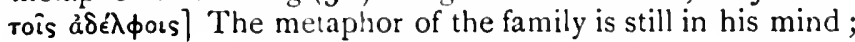
cf. $3^{15}$ and $5^{1}$.

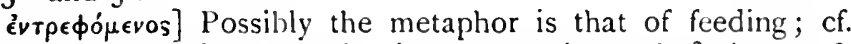

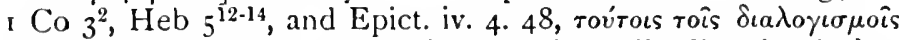
cvrpeфópєvos, M.M. s.v., "reading and inwardly digesting"; but more probably "training yourself in": cf. Eur. Phan. 368,

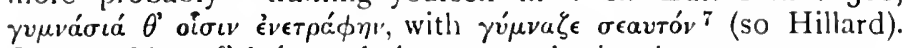

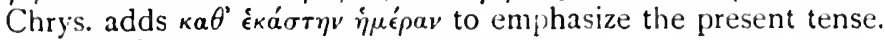

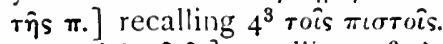

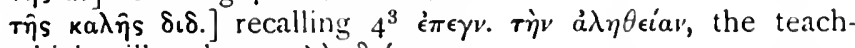

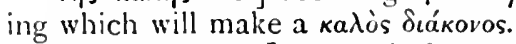

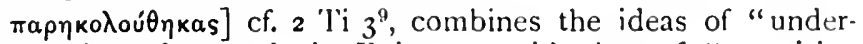
standing," as frequently in Epictetus, with that of "practising perseveringly."

7. roùs $\delta \grave{\epsilon} . . . \mu u$ tous] The myths which the false teachers are propagating, $\mathrm{cf} \mathrm{I}^{4}$ note; not necessarily to be identified with the teaching in ${ }^{1-5}$ supra.

$\beta \epsilon \beta$ ńtous] "ineptas," Vulg. ; "profanas," O.L., Ambros. ; contributin sothing to $\epsilon \dot{v} \sigma \epsilon \beta \epsilon \epsilon^{\prime} \alpha$.

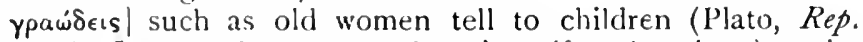

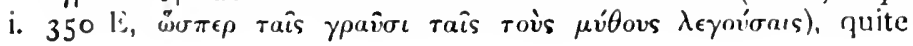


unfit for strong young men who have to be trained to discipline

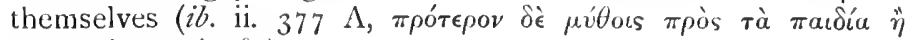

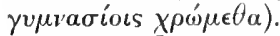

$\gamma u ́ \mu v a \zeta \epsilon]$ but you are full-grown, you have to be even your own trainer-perhaps with the thought "in my absence" (so Bengel) implied. Your training must be of your whole self, body and soul, not for health or a crown in the games, but for living a religious life. Dibelius quotes Isocr. ad Nicoclem, 10, ovjóv $v \iota \hat{\omega} \nu$

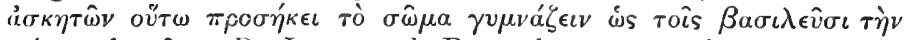

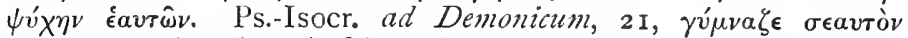

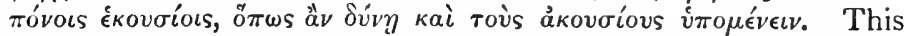
the $\epsilon \dot{v} \sigma \epsilon ́ \beta \eta$ s would need; cf. 2 Ti $3^{12}$. For further very interesting illustrations see Wetstein.

8. if $\sigma \omega \mu . \gamma u \mu v$.$] "corporalis exercitatio," Vulg. The refer-$ ence is to either: (i) ascetic discipline, the thought of 3 being still in his mind: you, too, will need discipline of the body, but it must be from a right motive, and only as a means to an end, for in itself it goes a very little way. On this interpretation the best comment is $\mathrm{Col} \mathbf{2}^{20-23}$; or (ii) athletic discipline : an illustration from the ordinary training in the gymnasium; and the best comment is I Co $9^{24-27}$. This is the more probable, as the subject of ${ }^{3}$ seems to have been dropped at ${ }^{5}$, and it is supported by $\stackrel{a}{\alpha} \gamma \omega \nu \iota \zeta^{\prime} \mu \epsilon \theta \alpha^{10}$.

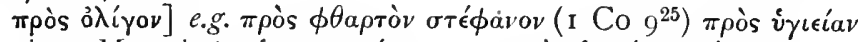

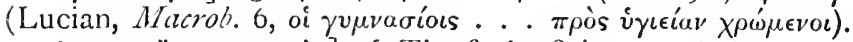

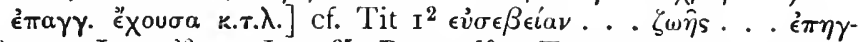

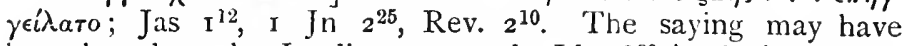

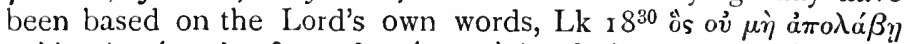

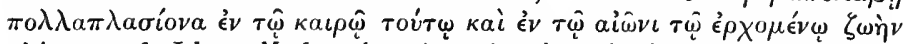
uívıov, cf. Lk $12^{15}$ for the thought, but it has earlier Jewish analogies ; cf. Pirke Aboth iv. 2. "Who is rich? He that is contented with his lot: for it is said, Happy art thou in this world, and it shall be well with thee in the world to come." True life lies in contentment $\left(6^{6}\right)$, in the glad acceptance of our lot, in gratitude for God's common blessings, in the sense that all things are ours through union with Christ, I Co $3^{22}$; cf. Chrys. ad loc., or Traherne's Meditations.

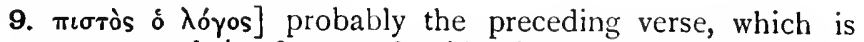
more stereotyped in form and wider in application than the Christian experience which supports it ( $\gamma a \dot{\rho} \rho)$.

$\pi \alpha ́ \sigma \eta \mathrm{s}] \mathrm{cf} . \mathrm{I}^{15}$ note: here perhaps anticipating $\sigma \omega \tau \grave{\eta} \rho \pi \alpha ́ \nu \tau \omega \nu 10$ as $\pi \iota \sigma \tau o$ s leads up to $\pi \iota \sigma \tau \hat{\omega} \nu$. Those who have faith have found this saying trustworthy, and it is worth all men's while to accept it.

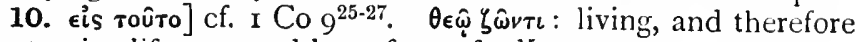
able to give life now and hereafter; cf. $3^{15}$ note.

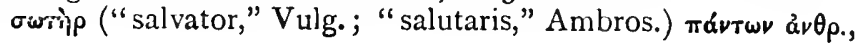


perhaps, as giving them their life ("quia ex ipso et per ipsun:

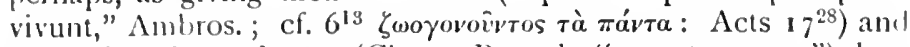
protection from danger (Chrys. Bengel, "servat omnes"), but, much more deeply, as giving them the instincts that feel after Him (Acts $I 7^{2 i}$ ), and as longing for their full spiritual salvation $\left(z^{4}\right)$.

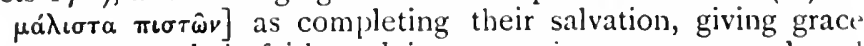
in response to their faith and in proportion to every need, and life to meet a daily dying; cf. I Co $15^{31}, 2$ Co $4^{10-15}$. The difference of treatment lies not with God, but with men themselves. He is always Father and Saviour; but they who trust $\mathrm{Him}$ as such and accept the revelation through $\mathrm{His}$ Son, know that $\mathrm{He}$ is such and gain a fuller life. Cf. Plut. Alex. p. $68_{3} \mathrm{~A}$,

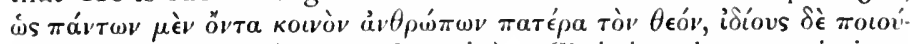

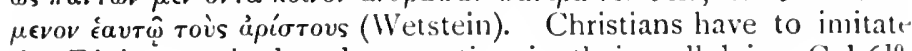
the Divine method and proportion in their well-doing, Gal $6^{10}$, Phil $4^{5}$.

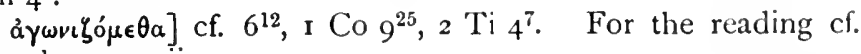
Introd. p. xxxvii.

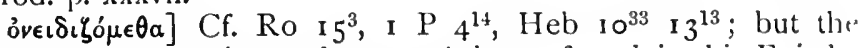
thought of persecution and reproach is not found in this Epistle, nor is it very appropriate to this context.

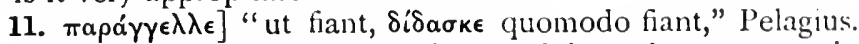

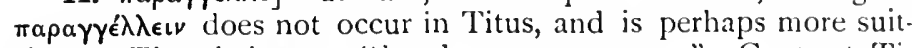
able to Timothy's age- "hand on my message." Contrast 'Tit $2^{15}$ (Ramsay, Expositor, 1910, P. 331).

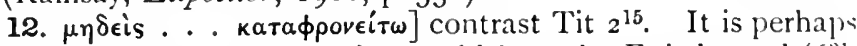
a side hint to the Church, who would hear the Epistle read $\left(6^{21}\right.$,

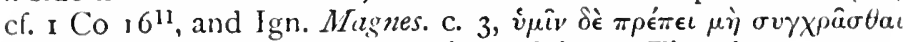

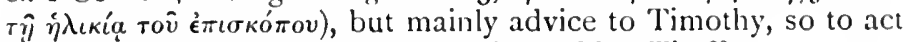
that none may be able to despise him. Cf. $2 \mathrm{Ti}^{22}$.

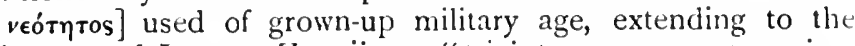
toth year; cf. Iren. c. Har. ii. 22, "triginta annorum atas prima indolis est juvenis et extenditur usque ad quadragesimum annum." For fuller illustration of. Ramsay in Expositor, igro, p. 327 , and Cities and Bishoprics of Phrygia, i. p. 110.

$\tau u ́ \pi o s . . . \tau \hat{\omega} v \pi\llcorner\sigma \tau \hat{\omega} v]$ not so much " a model for the faithful

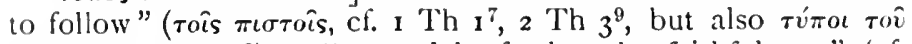
mourviov, I Pet $5^{3}$ ) as "a model of what the faithiul are" (cf. 'lit $\left.2^{7} \tau \dot{v} \pi o v \kappa \alpha \lambda \hat{\omega} v{ }^{\prime} \rho \gamma \omega \nu\right)$, which will make its appeal to all men (cf. ${ }^{20} .15$ ) and attract them to complete salvation (cf. $2^{3-8}$ ).

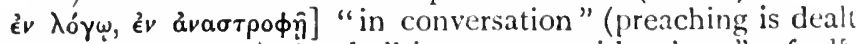
with in the next verse), "and all intercourse with others"; cf. $3^{15}$, 1 Pet $3^{1.2}$. These give the sphere, the next three the qualitie's in which he is to be a model.

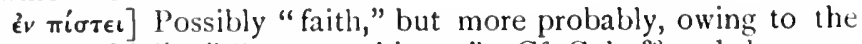
context, "fidelity," "trustworthiness." Cf. Gal $5^{222}$ and the com- 


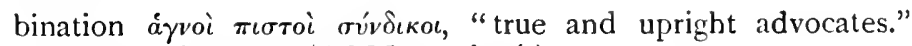

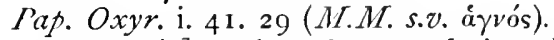

év áyve[a] purity of act and thought. The transition from ritual to moral purity had already been made by the Greeks; cf. the Inscription on the temple at Epidaurus :

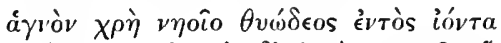

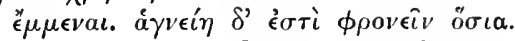

Clem. Alex. Strom. v. I. 13.

Cf. the account of the early Christians given to Pliny, Ep. x. 97. "soliti essent . . . se sacramento obstringere ne furta, ne latrocinia (= $\left.\dot{a} \gamma \alpha^{\prime} \pi \eta\right)$, ne adulteria $\left(=\dot{\alpha} \gamma v \in \epsilon_{\mathfrak{c}}^{\prime} \alpha\right)$, committerent, ne fidem faller ent, ne depositum appellati abnegarent $(=\pi i \sigma \tau \epsilon)$."

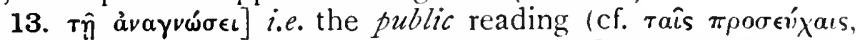
$5^{5}$, Acts $2^{42}$ ), as in the Jewish synagogues (cf. Charles on Rev $\mathrm{I}^{3}$ ) This would, with the O.T., include Apostolic letters ( 1 Th $5^{2 i}$, Eph $3^{4}$, Col $4^{16}$, Euseb. H.E. 4. 23), apocalypses (Mk $13^{14}$, Rev $\mathrm{I}^{3}$; cf. Tert. Apol. 39, "cogimur ad litterarum divinarum commemorationem si quid presentium temporum qualitas aut praemonere cogit aut recognoscere"), the memoirs of the Apostles or the writings of the prophets (Justin M. Apol. i. 67).

$\left.\pi \rho \sigma^{\sigma} \epsilon \boldsymbol{X}\right]$ This will include his own reading (cf. Tit $\mathrm{r}^{9}$ ) and t'rat of any official to whom it was deputed. It will imply-

(a) A wise choice of the passages to be read: cf. Apost. Const. ii. 5 (infra).

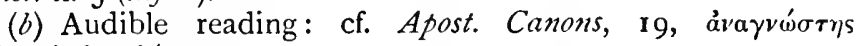

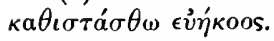

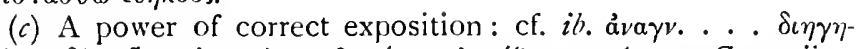

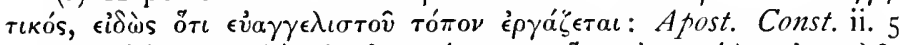

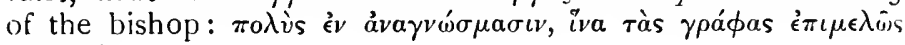
є̇ $\mu \eta v \in$ v́n.

Such supervision will necessarily imply previous private

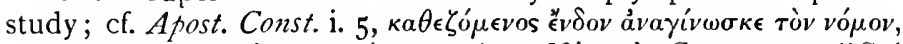

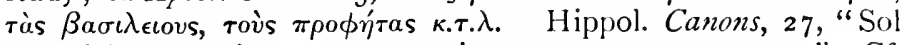
conspiciat matutino tempore scripturam super genua tua." $\mathrm{Cf}$. $2 \mathrm{Ti}^{15}$.

For an interesting analogy, cf. Pap. Oxyr. iii. 53I, from a

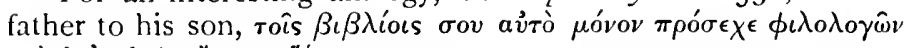

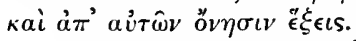

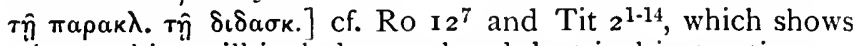
that the teaching will include moral and doctrinal instruction.

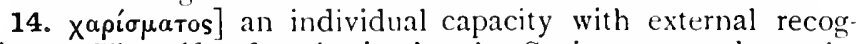
nition. The gift of authority by the Society strengthens the individual's power and confidence : cf. $3^{13}$. Here the gift combines the capacity to preach himself and the authority to control others. 


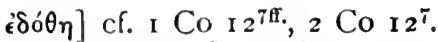

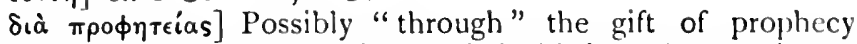
given to "Timothy himself, which carried with it the lesser $\chi$ áp (Pelag. Ambros.); but Timothy is never elsewhere treated as a prophet, hence, almost certainly, through the utterance of some prophet or prophets; $c f .{ }^{18}$.

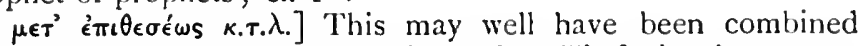
with the laying on of the Apostle's hands, $2{ }^{~} \mathrm{Ti}^{6}{ }^{6}$; but here stress is laid on the action of the presbyters, because Timothy has to exercise discipline over them $\left({ }^{13} 5^{17 \cdot 25}\right)$. They have themselves recognized your authority.

When and where was this gift given? Either at Lystra on the first choice of Timothy as minister (so Hort, Christian Ecclesia, p. I87, and, more doubtfully, Ramsay, Expositor, I910, p. 325), or at Ephesus when left there by St. Paul. The latter suits this context better.

To what office? The laying on of the hands of the presbyters would, if later usage is a guide, point to the presbyterate: cf. The Egyptian Ch. O. (Connolly, pp. 178, I79); but it might be to an "overseership," a preshyter being associated sometimes with the bishops in the ordination of a bishop: cf. Wordsworth, Ministry of Grace, p. 167 . For the very doubtful tradition that at Alexandria presbyters alone consecrated a bishop, vid. C. H. Turner, in Cambridse Mediceval History, i. pp. I55-6r.

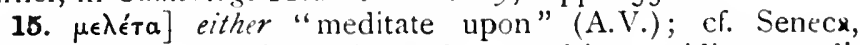
Ep. I6, "hoc quod liquet firmandum et altius cotidiana meditatione figendum est" (Wetstein), and Darwin's advice to G. J. Romanes-"Always cultivate the habit of meditation."

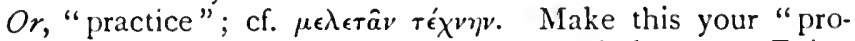
fession," cf. $5^{13}$ ravtávovorv: and for the whole verse, Epict.

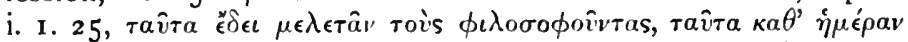

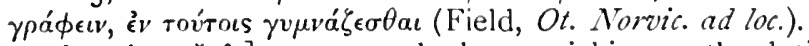

Év roútoıs $\left.\imath^{\sigma} \sigma \theta_{\iota}\right]$ an unusual phrase, picking up the duties and

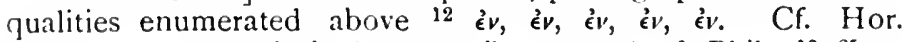

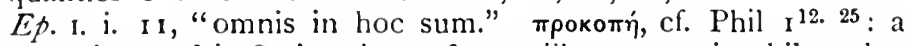
favourite word in Stoic writers of a pupil's progress in philosophy. Bonhoffer, Epict. p. I 28 . $\pi \hat{a} \sigma u v$ : so that no one nay despise thee ${ }^{12}$.

16. $\check{\epsilon} \pi \epsilon \in]$ Give heed to, keep an eye upon (cf. Lk $14^{7}$, Acts $3^{5}$ ) thy own life and the teaching which you ( $\mathrm{Q}_{y}$. and

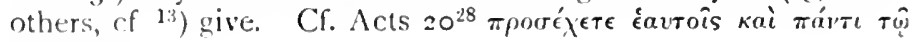

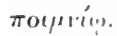

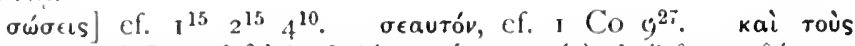

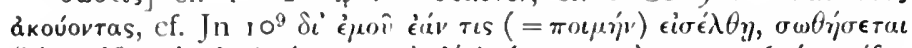

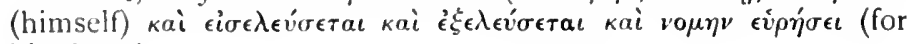
his sheep). 
v. 1-vi. 2. Advice to Timothy how to deal with various classes in the Church: older men and younger men ( $\left.{ }^{1}\right)$, older and younger women $\left({ }^{2}\right)$, widows $\left({ }^{3-16}\right)$, presbyters $\left({ }^{17-25}\right)$, slaves $\left(6^{1.2}\right)$.

"Those who hear thee" $\left(4^{16}\right)$ are now subdivided: there is no single line of division: it is partly age, partly official position in the Church, partly social status; but two thoughts are common to the section. (i) The respect due to all, as members of the

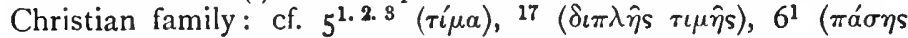
$\tau \iota \mu \hat{\eta} s$ ). There must be honour paid to real need, to good service, to social position. The thought of the family is carried on from

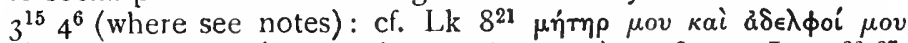

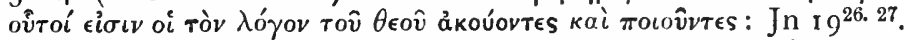

(ii) The importance of winning respect among their pagan neighbours, cf. $5^{\text {7. 8.14 }} 6^{1}$. Wetstein's notes on the whole passage illustrating the various commands from Greek and Roman writers are most illuminating in this respect.

Cf. Titus c. 2 throughout, which deals with the same problem from the point of view of the teaching to be given to each class.

1, 2. Paraphrase. If you have to correct any, suit your correction to their age. Never sharply chide an older man, but appeal to him as you would to your own father; to younger men as to brothers; older women treat as mothers; younger women as sisters, with purity of thought and speech and deed.

$\left.\pi \rho \in \sigma \beta u \tau^{\prime} \rho \omega\right]$ cf. Lev $19^{32}$ " Thou shalt honour the face of the old man"; Ecclus $8^{6}$ "Dishonour not a man in his old age" (but note the difference of motive), "for some of us also are waxing old."

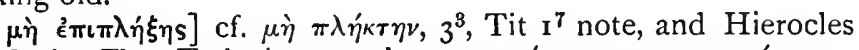

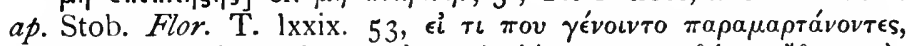

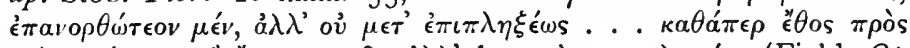

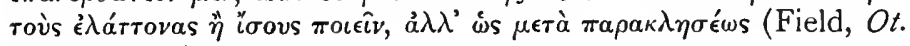
Norv. ad loc.).

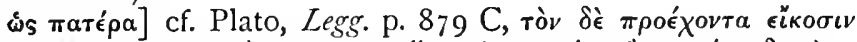

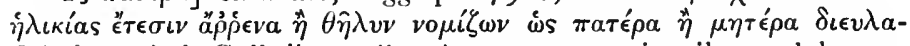
$\beta \epsilon \hat{\imath} \sigma \theta \omega . \quad$ Aul. Gell. ii. 15, "majores natu a minoribus colebantur ad Deum prope et parentum vicem" (Wetstein). "One who has been familiar with the ordinary Greek usage in modern times can feel no doubt that these verses imply that Timothy should actually address men and women older than himself by the titles 'father' and 'mother,' while he was advised to salute those who were approximately of the same age with himself as 'brother' and 'sister'" (Ramsay, Expositor, 1910, p. 326).

2. ¿s $\mu \eta \tau$ répas] cf. Ro $16^{13}$ " his mother and mine."

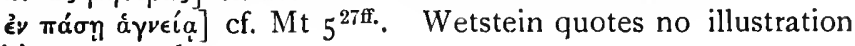
of this command. 
3-16. The care for widows, based on natural sympathy for suffering ( characteristic of the Jews (cf. Ps $68^{6}$, Dt ${ }_{1} 0^{18} 24^{17}$, Is $1^{17}$, Lk $2^{37}$ ) and carried on at once by the Christian Church (Acts $6^{1}$, Jas ${ }^{27}$; Ign. Smyrn. 6, with Lightfoot's note). They received of the alms of the Church (Justin M. Apol. i. 67), and were specially commended to the bishop's care (Ign. ad Polyc. 4). A common instinct drew them together, and they were grouped as a body (Acts $9^{39.41} \pi \hat{\alpha} \sigma a \iota$ ai $\left.\chi \hat{\eta} \rho a \iota\right)$ occupied in deeds of kindness to the

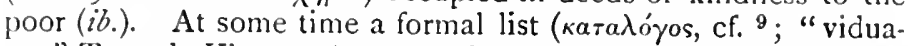
tus," Tert. de Virg. v. 9) was made of them, and there were two classes of them, one objects of honour and charity, the other active officials of the Church; cf. Eg. Ch. Order, pp. 180, 189; Hippol. Canons, 59, 157, and most fully for the later details; Test. Dom. N. 40-43 (with notes by Maclean and Cooper); Const. Apol. iii. 1-3 ; St. Chrys. de Sacerdot. iii. 16 ; Dict. Christ. Antiqq. s.v.; Wordsworth, Ministry of Grace, pp. 264-74.

The exact status implied here is not clear. A formal list is assumed to exist $\left({ }^{9}\right)$ : there is a danger that unworthy $r \in$ cipients of charity will be admitted, and the main purpose of the writer is to control applicants, to exclude rather than to include (4. 3.15): some have already been untrue to their ideal $\left({ }^{12}{ }^{15}\right)$. These facts imply some lapse of time. On the other hand, there are more detailed regulations for the qualifications of a widow than there were for bishop or deacon, as if the order were not yet fully established; and there is a more definite recommendation of second marriages than would have been likely in the and century. It is also not clear whether two classes are implied here: (a) recipients of charity, not included in any list but dealt with as necessity arose ( $\left.{ }^{4-8}\right)$, and $(b)$ active officials busied with leeds of kindness $\left({ }^{9-15}\right)$. This is possible, though we might expect such a distinction to have been more clearly marked at v. ${ }^{9}$.

The care of widows would be required rery early, and all that is laid down here would be possible in a church that had been founded for ten years.

Paraphrase. In dealing with widows, distinguish between those who have any to support them and those who have not. To the last give official recognition and support; but if any have children or grandchildren, let these learn their first lessons in true piety by respect for their own family, and make due return to their forbears, for this is acceptable in God's sight. But nne who is really a widow and lift entirely alone in the world has only God to trust in, and remains constant in her prayers and supplications evening and morning: whereas a widow who lives a life of pleasure and self-indulgence is no better than a living rneרs IInnd $n \mathrm{n}$ tn them these instructions, that none of them 
may be liable to censure. But any Christian who makes no provision for his own kith and kin, especially those who live under his own roof, thereby gives the lie to the Christian faith and is worse than his heathen neighbours.

There is another distinction to be made. You must have an official list for widows in the service of the Church, and no one should be put on this list unless she is at least sixty years old, and has proved herself faithful to her husband: she must be one of whom her neighbours speak well for her kind actions, if she has brought up children carefully, if she has shown hospitality to strangers, if she has with her own hands washed the feet of God's people on their travels, if she has relieved those in trouble-in a word, if she has at all times thrown her whole heart into good deeds.

But do not put on your list of widows any one younger than sixty. For such, whenever they chafe and fret against the restrictions which their allegiance to Christ involves, wish to marry and so expose themselves to censure as being untrue to their first devotion to Him. Nay, more than that, they also train themselves to be nothing better than idlers, as they gad about from house to house: yes, not only idlers but gossips and busybodies, thattering about things on which it is better to be silent. It is my wish therefore that younger women should marry, bear children, rule their households, and so give no occasion to any enemy to abuse the Church. For, short as the time has been, yet some have already turned aside from their allegiance to Christ to be followers of Satan.

One word more. If any such woman has any widows in her household, she should, as I have already said about men, support them herself and not let the expense fall on the Church funds: they are needed for the support of those who are widows in the fullest sense, with no one to support them.

Parry suggests a possible displacement of the text and would arrange the verses in this order: 3. 4.8.7.5.6.9. This would be more natural, but is scarcely necessary.

3. Tía] "Show due respect and honour to" (cf. vv.1. 2 and $\left.6^{1}\right)$. Such respect would include $(a)$ sustenance when needed. Cf. ${ }^{17}, \mathrm{Mt}$ I $5^{4-6}$; and Wohlenberg aptly quotes Hom. Il. I 2. 310.

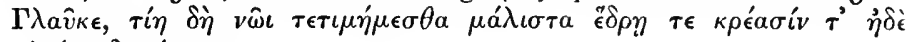
$\pi \lambda \epsilon i o \iota s \delta \epsilon \pi \alpha \dot{\epsilon} \sigma \sigma \iota \nu$;

(b) Perhaps also a special seat in the meetings and rank in the Church hierarchy; cf. Origen, in Joannem, ii. p. 412 (Lom.

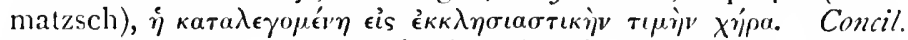

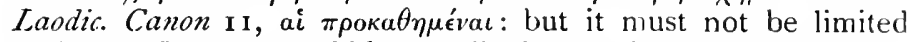
to these. Respect would be equally due to widows not supported by the Church, cf. ${ }^{4}$; cf. Hippol. Canons, 59, "Viduis propter 
copiosas orationes, infirmorum curam et frequens jejunium precipuus honor tribuatur."

$\tau \grave{a} s$ övTws] in contrast to $(a)$ any who have friends who can support them ${ }^{4} ;(b)$ any who live self-indulgent lives, who deserve neither support nor respect ${ }^{6}$.

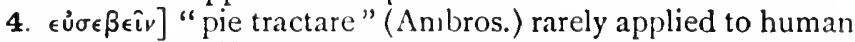
heings, though $\epsilon \dot{v} \sigma \epsilon \in \beta \epsilon \alpha$ was used of loyalty to the Emperor (cf. $2^{2}$ note, and vid. M.M. s.v.): here $\pi \rho \hat{\omega} \tau o v$ suggests deeper lessons to be learnt afterwards. Let them learn their first lessons in $\epsilon \dot{v} \sigma \epsilon \beta \epsilon \epsilon^{\prime} \alpha$ in their treatment of their own parents : then they will know how to reverence God's family (cf. $3^{15}$, supra ${ }^{1.2}$ ) and God Himself ; cf. note on ${ }^{8}$.

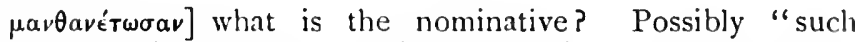
widows" making return to their forbears by due treatment of their own children or grandchildren (Chrys. Thdt. Pelag. Holtzmann, Wohlenberg), but more probably "such children and

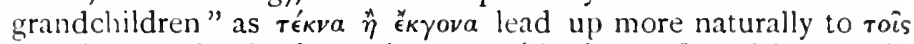
$\pi$ poyorors, and this gives a better antithesis to $\mathrm{v}^{5}$, and is more in accordance with the whole drift of the paragraph which is about the support of widows rather than their duties (so Theod.-Mops. Bengel, Liddon, von Soden). For the sense of this filial duty in the pagan world, cf. Eur. Or. 462-69, Iph. in Aul. I228;

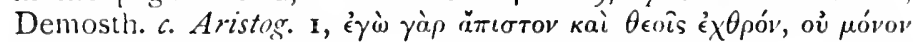

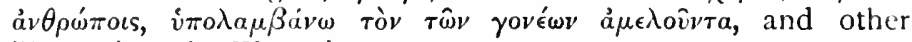
illustrations in Wetstein.

anorßás] The plural is common (even when speaking of one

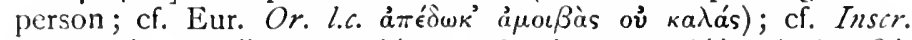

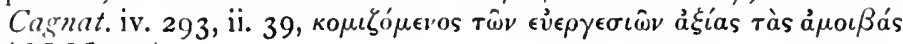
(M.M. s.v.).

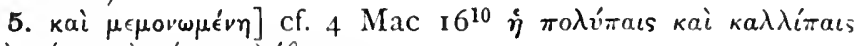

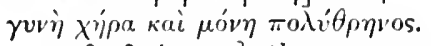

rais $\delta \in \eta \dot{\sigma} \sigma \sigma u$ ] the prayers, i.e. those at the meetings of the

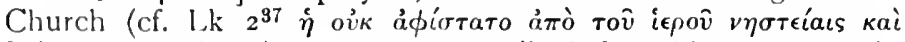

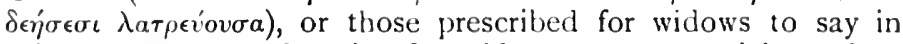
private. IIymns of praise for widows to say at night and at dawn are given in full in Test. Dom. N. c. 43 .

6. $\sigma \pi \alpha \tau a \lambda \bar{\omega} \sigma \alpha]$ probably akin to $\sigma \pi \alpha \dot{\omega}$, to suck down, hence to live luxuriously, self-indulgently, often combined with $\tau \rho v \phi \hat{a} v$ :

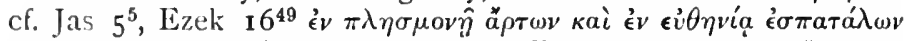

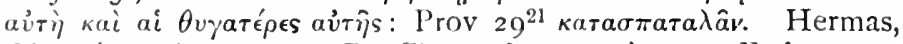
Sim. vi. I ; Barn. x. 3 ; Ps.-Chrys. de pena, ix. 277 E, o $\sigma \pi \alpha \tau \alpha$ $\lambda$ irstils ékeiros of Dives in $\mathrm{Lk}_{\mathrm{I}} 6^{19}$. For these and other illustra. tions, r.f. Hort on Jas. ubi sup. and Add. Note, p. ro7. Vuig. "qua in deliciis est"; Th.-Mops. "solis epulis et deliciis vacare properans."

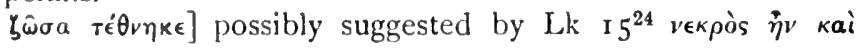


"' $\zeta \eta \sigma \epsilon$ (Resch), but the thought is common; cf. Rev $3^{\mathrm{I}}$ oै $v o \mu \alpha$

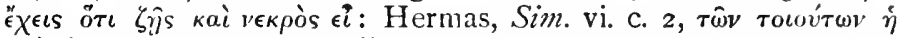

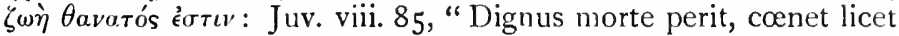
ostrea centun Gaurana"; Cic. ad Att. xii. 2, "Homini non recta sed voluptaria quærenti nonne $\beta \epsilon \beta i \omega \tau \alpha \iota$ ? " (cf. IVetstein for other illustrations). So Dante sees in hell the soul of Friar Alberigo whose body is still on earth (Inf. xxxiii.).

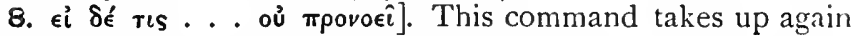
the command of 4 , showing that the duty of children or grandchildren was part of a general law of Christian duty. It may include the duty of a Christian providing for his widow and children in case of his death (so Hofmann and Wohlenberg; cf. Judith $8^{7}$ and the requirement of Jewish Law, that a husband should always so provide for his widow at the time of marriage, vid. Jererish Encyclopadia, s.v. Ketubah), but it cannot be limited to that. There is an interesting analogy to this argument in Philo, de Decalogo, 23 , who argues that men who neglect their parents are worse than storks, who show $\epsilon \dot{v} \sigma \epsilon \beta \epsilon i a$ (cf. ${ }^{5}$ supra) towards them and provide for them in their old age; and he concludes

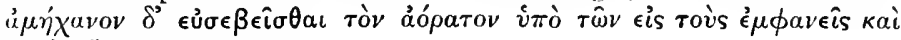

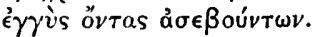

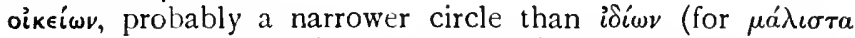
cf. $4^{10}$, Gal $6^{10}$ ), his relations, and especially any who are still members of his household; but the two may refer to the same persons, those who are his own kin and most closely intimate with him (Expositor, Jan. I922).

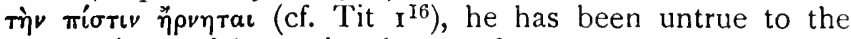
Christian faith, which requires honour for parents as part of the Christian duty.

aniorou $\mathrm{X} \epsilon i \rho \omega \nu]$ (a) Because unbelievers perform the duty; cf. Eur. Fragm. 852 (Nauck):

$\ddot{o} \sigma \tau \iota \varsigma \delta \hat{\delta} \tau \hat{\omega} \phi \dot{v} \sigma a \nu \tau \epsilon \mu \grave{\eta} \tau \iota \mu \hat{\alpha} \nu \theta \hat{\epsilon} \lambda \epsilon \iota$

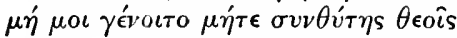

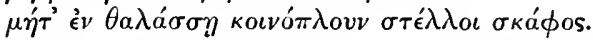

(b) Because he has not only the law of nature but the law of Christ to guide him, cf. Gal 6. ${ }^{20}$. For similar appeal to heathen morality, cf. Ro $2^{14}$, I Co $5^{1}$, Phil $4^{8}$; and for the same a fortiori argument, Jn $19^{11}$.

9. $k a \tau a \lambda \epsilon \gamma \epsilon \sigma \theta \omega(\stackrel{a}{\alpha} \pi . \lambda \epsilon \gamma$. in N.T.) placed on a list of those who were pledged (cf. niortv, ${ }^{12}$ ) to life-long widowhood.

$\dot{\epsilon} \tau \hat{\omega} \boldsymbol{\omega} \varepsilon \dot{\xi} \xi \dot{\eta} \kappa o v \tau a]$ when the desire for marriage 12 would have passed; the age fixed by Plato for men and women to become priests and priestesses in his ideal state (Laws, p. 759 D), and regarded by Orientals as the time for retiring from the world for quiet contemplation (Ramsay, Expositor, r 910, p. 439). 


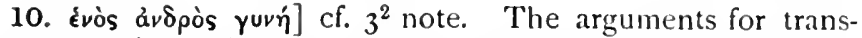
lating "married only once" are stronger in this case, because of the dislike of "nuptiæ secundæe" and the praise of the "univira" or "virginea" both in the Jewish (Judith $\mathrm{I}^{22}, \mathrm{Lk}^{36}$ ) and in the heathen world (cf. Tert. ad Uxor. i. c. 6, De Monog. c. I 7 , and illustrations in Wetstein). Yet the permission to remarry it points the other way; the writer would scarcely exclude from the official list a widow who on his advice had remarried and again become a widow. Hence "faithful to one man" remains

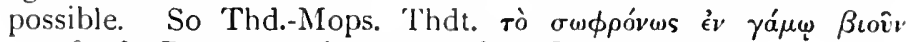
vo $\mu \circ \theta \epsilon \tau \epsilon \hat{\imath}$ : Ramsay and many modern Commentators.

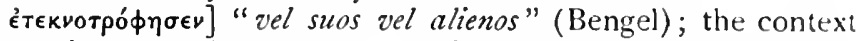

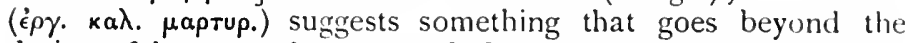
duties of her own home; and Church widows later had the charge of orphans, Herm. Mand. viii. There may be impliedif she has not exposed her children, but brought them up (Hillard).

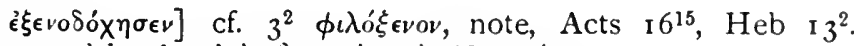

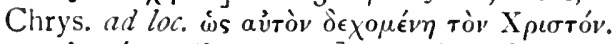

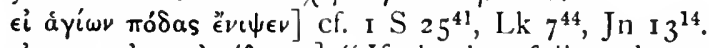

$\epsilon i . . . \dot{\epsilon} \pi \eta \kappa o \lambda o u ́ \theta \eta \sigma \epsilon v$ ] "If she has followed up thoroughly

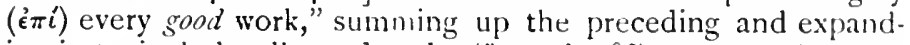
ing it to include all good tasks ( $\left.\epsilon^{\prime} \rho \gamma \omega \dot{a} \gamma \alpha \theta \hat{\omega}\right)$, not merely those

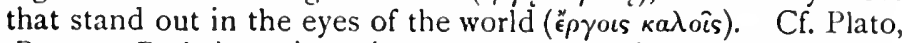

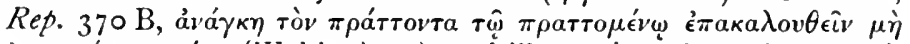

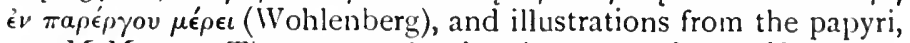
ap. M.M. s.v. There may also be the new point-" "if she has helped in the good works which others have begun" (Liddon), but this would probably have been more clearly expressed.

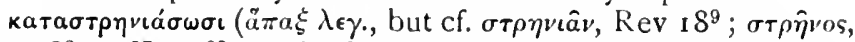
$\operatorname{Rev} \mathrm{I} 8^{3}, 2 \mathrm{~K} 19^{28}$ used of the Assyrian king, rò $\sigma \tau \rho \hat{\eta} v o$ s oov $\dot{a} v \dot{\epsilon} \beta \eta \dot{\epsilon}^{\prime} v$ rois $\left.\dot{\omega} \sigma \dot{i} \mu o v\right)$, to grow physically restless and so restive against the limitations of Christian widowhood; Apost. Const.

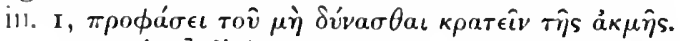

12. крíra] liable to severe judgment, i.e. primarily of men (cf. ${ }^{14}$ ), though the thought of the divine judgment lies in the

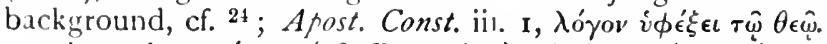

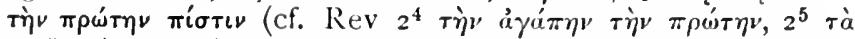
$\pi \rho$ (i) ${ }^{\prime \prime} \rho \gamma \alpha$ ), the original impulse of faith which led her to join the widows; or more exactly "the first troth" or " promise of allegi-

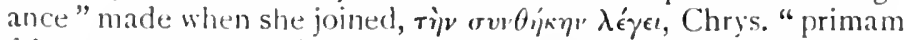

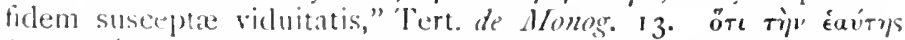

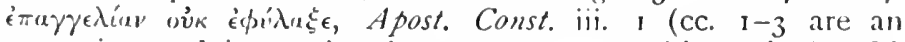
expansion and interesting later comment on this section). Cf.

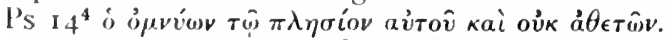

13. apyai $\mu a v \theta$ ávovol] "they learn to be idle," an unusual 
construction, but found in the technical phrase of learning a

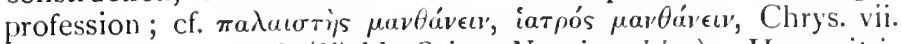
p. 699 A, ix. p. 259 Bi (Field, Otinm Norric. ad loc.). Hence it is unnecessary to suppose that eival has dropped out of the text

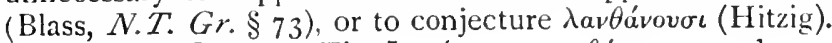

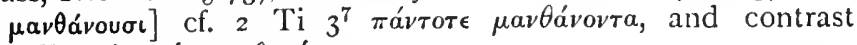

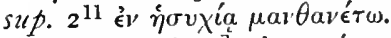

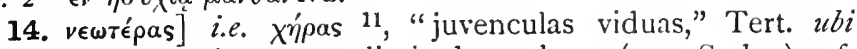
sup.; though, perhaps, not limited to them (von Soden), cf. Tit $2^{4.5}$.

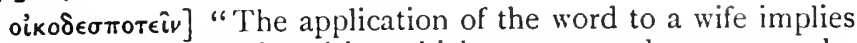
the new and improved position which was secured to women by

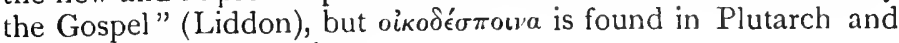
other non-Christian writers.

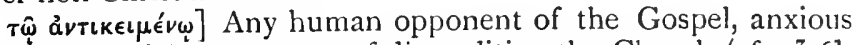
to use a scandal as a means of discrediting the Church (cf. $3^{7} 6^{1}$, Tit $\mathbf{2}^{5.8}$, I Co $1^{9}$ ); or perhaps "The Adversary," i.e. Satan, as in (Philo) Bibl. Ant. xlv. 6, the human adversary being thought of as his agent.

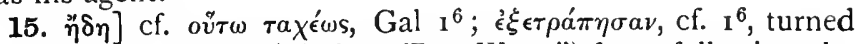
out of the true path (cf. the "Two Ways") from following the

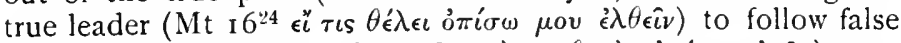

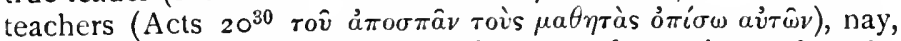
the great opponent himself, i.e. by second marriage after the promise of perpetual widowhood; or by such lives as those described in ${ }^{13}, \mathrm{cf}^{2} 2 \mathrm{Ti}^{6}$.

16. $\epsilon \ddot{\imath}$ TเS $\pi\left\llcorner\sigma \tau \eta^{\prime}\right]$ The general principle (cf. ${ }^{4}$ and ${ }^{8}$ ) is reasserted and applied to women, who have just been thought of as managing households $\left({ }^{14}\right)$. Such a woman may have a widowed mother, or grandmother, or daughter, or even servant in her house.

17-25. Discipline over presbyters.

(a) Reward for faithful work, 17. 18. 25 .

(b) Censure for faults, $19-22.24$.

Personal digression, ${ }^{23}$.

Cf. Apost. Const. ii. 6 sqq. Apost. Canon 74, 75 for later expansion of these rules; and for the spirit in which the discipline was exercised, cf. Tert. Apol. 39, "judicatur magno cum pondere, ut apud certos de Dei conspectu, summumque futuri judicii præjudicium est."

Paraphrase. Let such presbyters as have presided well be treated by the Church as deserving of yet greater honour and more ample support, especially those who take pains with preaching and teaching, for Scripture lays down the definite command, "Thou shalt not muzzle an ox when treading out corn," and the I.ord Himself has said, "The labourer is worthy 
of his wages." If an accusation is brought against any presbyter, refuse to listen to it unless it is supported by two or three witnesses. But those preshyters who are proved guilty rebuke before all, that the rest may fear to imitate them. When you act as julge, keep before yourself the thought of the last judgment, of (jod, of Jesus Christ, of the chosen angels; and carefully observe these rules, never making up your mind beforehand, never acting out of favouritism. If you have passed censure on any one, do not be over hasty in remitting the penalty; do not let your own good name be soiled by contact with the sins of others; keep your own life pure and untarnished. You have done so hitherto and have with that view abstained from wine, but I would advise you no longer to keep this rule; take wine sparingly, as your digestion is weak and you are so often ill. Such weakness may impair your judgment. In your decisions as judge you will need careful patience; in some cases, no doubr, the sins are patent to everybody and lead you by the hand to a decision, but in others they only appear after investigation. In the same way excellent actions are, as a rule, patent to everybody, and those that are not cannot in the end remain hidden.

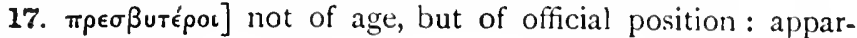

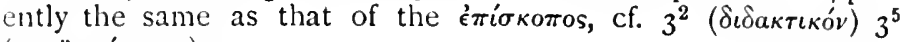

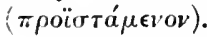

$\delta\llcorner\pi \lambda \hat{\eta} s \quad \tau \iota \mu \eta \bar{s}]$ in the widest sense "honour," "respect"

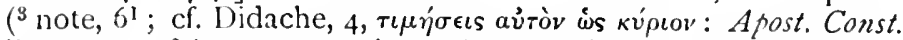

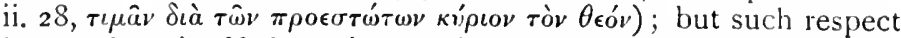
has to show itself through material support from the offerings of

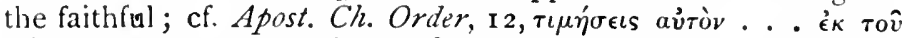

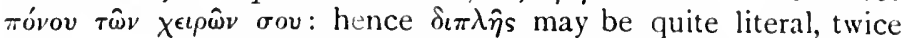
the amount of firstfruits (cf. Didache, c. I3) that is given to others, perhaps especially twice that given to widows ${ }^{3-16}$, cf.

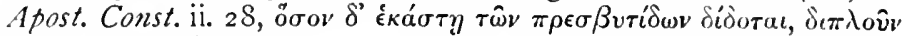

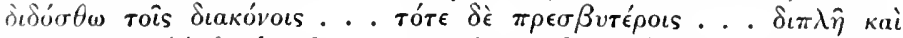

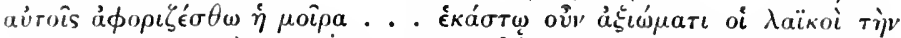

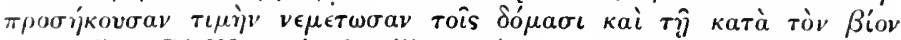
$\dot{\epsilon} \nu \tau \rho o \pi \hat{\eta})$. Cf. Wetstein for illustrations of double pay given to soldiers who had done good service.

oi $к \circ \pi \hat{\omega} v \tau \epsilon \varsigma$ ] distinguishes those presbyters who teach from those who only preside; or, perhaps, those who take special pain: from those who do not; cf. II $2^{6}$.

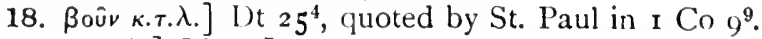

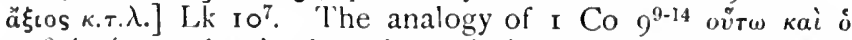

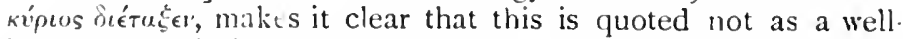
known proverb, but as a saying of the Lord. As such it might be known to the writer orally, or possibly in the Lucan copy of

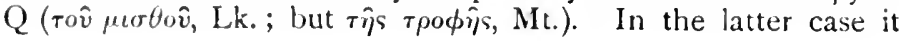


might be included under the introductory phrase $\dot{\eta} \gamma \rho a \phi \dot{\eta}$, and would be the earliest instance of the Lord's words being quoted as "Scripture."

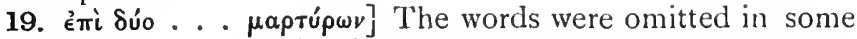
MSS known to Jerome, but in no extant MS, and are necessary to the context. Perhaps "Do not let an accusation be brought before you in private, unless two or three witnesses are present with you to hear it" (Holtzmann, Wohlenberg, cf. Apost. Canon

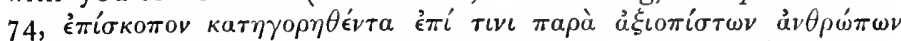

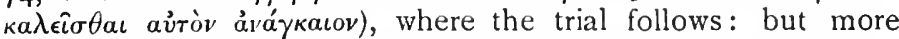
probably it refers to the actual trial, a short phrase equivalent to

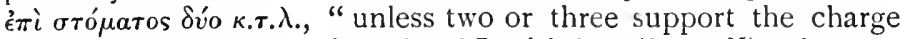
with their evidence "- the rule of Jewish law (Dt $19^{15}$ ) taken up by our Lord $\left(\mathrm{Mt}_{1} 8^{16}\right)$, by St. Paul $\left(2 \mathrm{Co}_{1} 3^{1}\right)$, and later applied

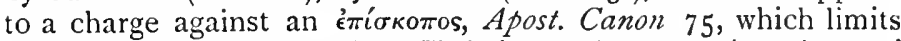

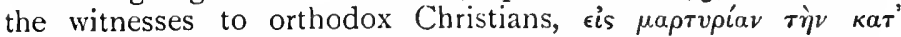

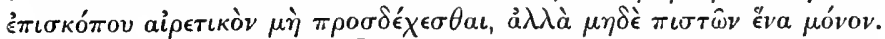

20. Toùs á $\mu a \rho \tau \dot{v}$ vovtas] perhaps "those who persist in sin" (present partic.), cf. 'Tit $3^{11}$. The context limits this and $\pi a^{\prime} \nu \tau \omega \nu$ and oi $\lambda o \iota \pi \circ i$ to presbyters.

21. Cf. II $4^{1}$, I Th $3^{13}$. The appeal is to the thought of those who will take part in the final judgment ( $M t ~ 25^{31}$ ), with the double suggestion-(a) Judge, as one who has to represent in earth the Divine Judge in heaven, cf. Mt $18^{18}$, and 'Tertullian, Apol. 39, quoted on p. 6I. (b) Judge, as one who will have himself to be judged for his actions as judge.

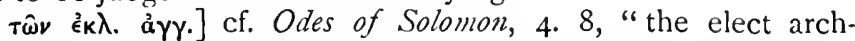

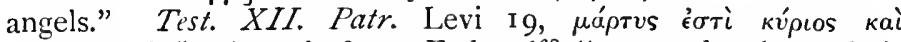

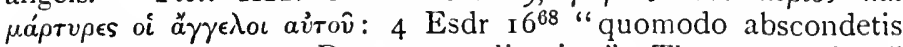
peccata vestra coram Deo et angelis ejus." They are "elect" in contrast to the fallen angels ; but the main thought is "chosen to share in the judgment "; cf. Charles, Rev I $4{ }^{10}$, and $\tau \hat{\omega} \nu \dot{\epsilon}^{\epsilon} \kappa \lambda \epsilon \kappa-$

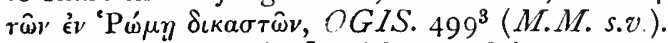

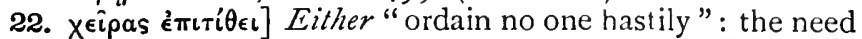
of discipline over presbyters suggests the importance of great care at ordination to prevent subsequent troubles: he must be careful to keep his hands quite clean, to allow no suspicion of favouritism or of condoning evil, lest he be tarred with the brush of others' sins. An interesting expansion of this will be found in Chrys. de Sacerd. iv. 374-78. This is supported by $3^{10}$ and the use of $\chi \epsilon i p a s$ e $\pi \iota \tau i \theta \epsilon v a \iota$ in the N.T. (so all the Greek commenators, von Soden), ${ }^{1}$ but it is not very appropriate to the context.

1 Wetstein quotes, to illustrate the thought, Isocrates, ad Demonic, $\S 38$,

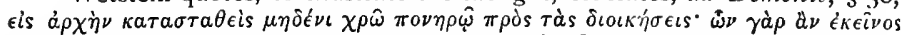

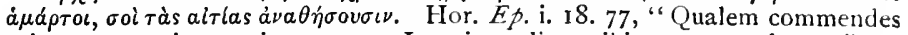
etiam atque etiam aspice, ne mox Incutiant aliena tibi peccata pudorem." 
Or, more probably, after you have passed judgment, do not be hasty in revoking it and receiving the offender back again into c.unmunion ; cf. Jas $5^{15}, 2 \mathrm{Co} 2^{6-11}$. This was done later by laying on of hands; cf. Cyprian, Ep. 74. \$12, "hos enim oportet cum redeunt acta paenitentia per manus impositionem solam recipi." Eusebius, H.E. vii. 2 (who speaks of it as a $\pi a \lambda a i o v ~ \stackrel{*}{\theta} \theta$ os for receiving heretics into the Church); Apost. Const. ii. I 8 (of any

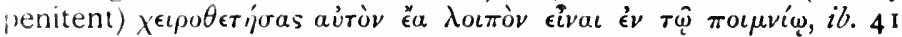
and 43. This suits better the context, which is one of discipline, and also the following command against being implicated in the sins of others ; cf. De Aleatoribus, \$ I, "salutari doctrina admonemur ne, dum delinquentibus adsidue ignoscimus, ipsi cum eis pariter torqueamur" (so Hammond, Ellicott, Hort (Christian Ecclesia, p. 2I4), Chase (Confirmation in the Apostolic Age, p. 65), Holtzmann).

23. áyvóv] of personal purity; cf. $4^{12} 5^{2}$, with perhaps a wider reference, free from all contact with evil and the sins of others ; cf. Apost. Const. ii. I 7.

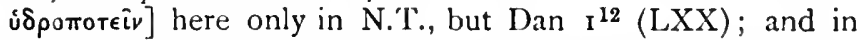
classical authors, cf. Harrison, p. 165 . 'This suggests that 'Timothy had adopted the rule of entire abstinence from wine, whether for example's sake or from ascetic reasons; cf. Dan $\mathrm{I}^{12}$; Philo, de Vit. C., p. 477 of the Therapeutæ. Similar advice is given for the bishop in Test. D. N. cc. 22 and $3 \mathrm{I}$; also cf. Epict. iii. 13. $2 \mathbf{I}$, and Hillard aptly quotes G. Herbert, $A$ Priest to the $T_{\varepsilon} m p l e$, c. $x$. "It may be added, not for emboldening the unruly but for the comfort of the weak, that not only sickness breaks the obligations of fasting, but also sickliness. For it is as unnatural to do anything that learls me to a sickness to which I am inclined, as not to get out of that sickness when I am in it, by any diet."

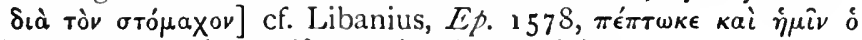

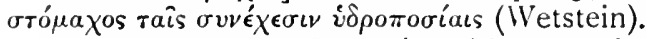

24,25 return to the main subject, emphasizing the need of careful examination both for praise and for censure. $\pi \rho \circ \delta \eta \lambda o i$,

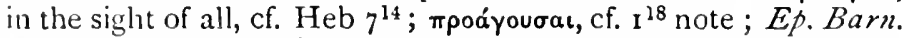

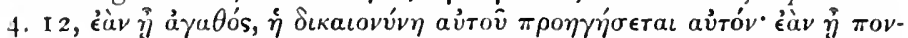

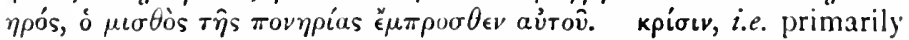
['imothy's judgment, but the thought of the Divine judgment lies behind (cf. Tert. Apol. l.c. p. 6r, and the Agraphon, ioov

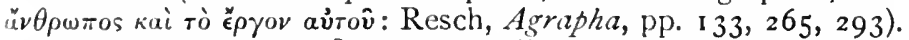

25. Tà ă $\lambda \lambda \omega s$ éx end be hidden, and you will be able to honour them adequately.

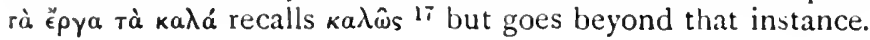

vi. 1, 2. The relation of slaves to their masters.

Paraphrase. This duty of proper respect holds good also 
of the relation of slaves to their masters. Some slaves will have heathen masters who make their life a burden to them; yet teach them to show all respect to such, lest the name of God and our teaching should be brought into disrepute. Others will have Christian masters : let such not fail in due respect, on the pretext that Christianity treats them and their masters as brothers; nay, let them serve them all the better on the very ground that those who share the good service are Christians and so dear to themselves.

Cf. I Co $7^{21}$, Eph $6^{5}$, Col $3^{22}$, Philem ${ }^{20-17}$, Tit $2^{9.10}$, I P $2^{18-25}$ (perhaps known to our author). Didache, 4. I I ; Ign. ad

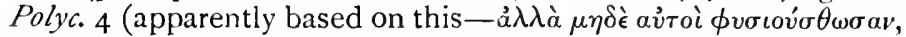

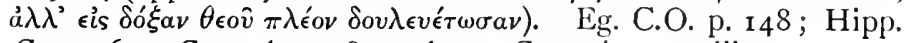
Canon 63; Can. Apost. 81 ; Apost. Const. iv. 12, viii. 3 I.

The treatment here points to an early date. No question is raised about using Church funds for emancipation (as in Ignatius), or of the relation of a slave who was to be baptized (Eg. C.O.; Hipp. Can.; Ap. Const.) or to be ordained (Can. Apost.) to his master. The writer has only to deal with the danger of Christian liberty and brotherhood being abused; cf. $2^{2}$ note, Gal $3^{28}$, I Co $\mathrm{I} \mathrm{I}^{2-16}$, and especially $\mathrm{I}_{\mathrm{P}}{ }^{11-18}$ (with Hort's notes). He meets it by laying stress on the respect due to all social positions

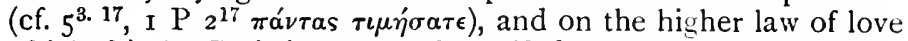

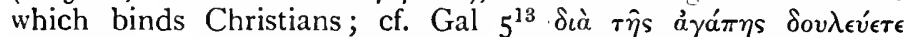
$\alpha \lambda \lambda$ ' $\lambda$ oss. The treatment falls in with the growth in the best heathen thought of the duty of a better treatment of slaves by their masters; Seneca, Ep. 47, "unus omnium parens mundus est"

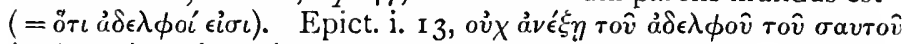

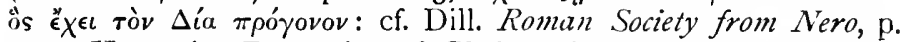
I 7 ; Harnack, Expansion of Christianity, i. pp. 208-i I (Eng. tr.): and of the power of slaves to confer not only service and duty, but freewill benefits upon their masters, Seneca, De Benefic. iii. $18-22$.

1. úmò Guyóv] perhaps not applied here to all slaves, but only to such as being under heathen masters feel their slavery as a yoke: cf. I $\mathrm{P}_{2}{ }^{18}$; Apost. Const. iv. I 2 ; Hippol. Can. 63, "si est heri idololatræ servus."

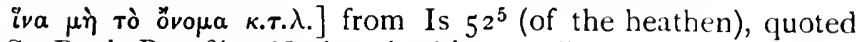
by St. Paul, Ro $\mathbf{2}^{24}$. Notice the higher effect of such conduct

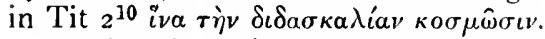

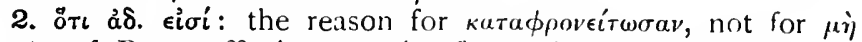

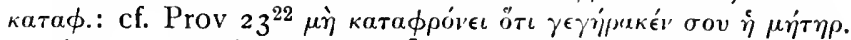

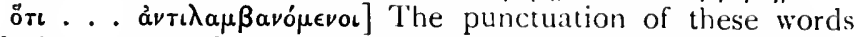
and the exact reference of each word are uncertain, but the

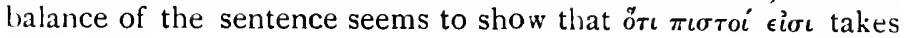


up $\pi \iota \sigma \tau o u$ s and is parallel to o̊ $\tau \iota \mathfrak{a} \delta \epsilon \lambda \phi o i$ $\epsilon i \sigma \iota$, and therefore must refer to the masters; and this probably carries with it the rest of the sentence, "because the nasters who receive the benefit of their better service are believers and beloved." But W.-H.

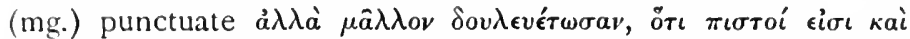

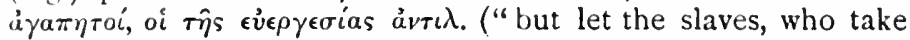
part in the benefit, serve all the better because the masters are believers and beloved "), and Wohlenberg punctuates $a \lambda \lambda \lambda \grave{\alpha} \mu \hat{a} \lambda \lambda o v$

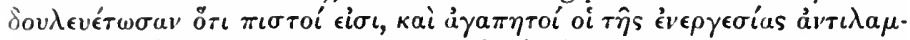
ßavórevo ("let those who have believing masters not despise them because they themselves are in Christ brothers to their masters; but let them serve all the better because their masters are believers, and those who take part in conferring kindness (as they would do by serving better) are always beloved"); but this destroys the parallelism between õ $\tau \iota \dot{a} \delta \epsilon \lambda \phi o i \in \epsilon \sigma \iota$ and õ $\iota$

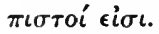

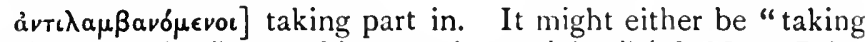
part in conferring" or "taking part in receiving" (cf. Mart. Polyc.

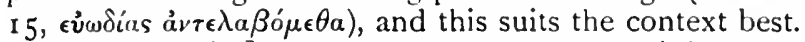

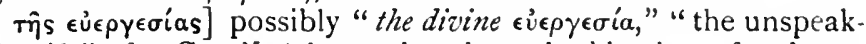
able gift" of 2 Co 9 "those who share the blessing of redemp-

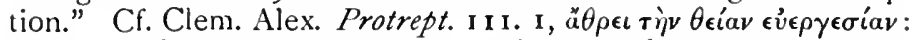

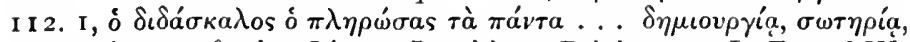

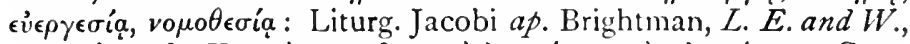
p. 4r, 'I $\eta \sigma o \hat{v} v$ X

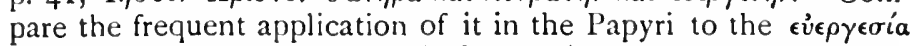
of an Emperor to his people (M.M. s.v.); and for the ground of

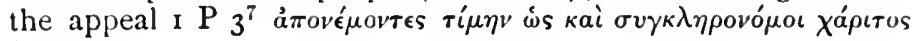
$\zeta \omega \hat{\eta} s$.

Perhaps more probably "the human kindness," not of the masters (Chrys. Thdt. Pelagius, von Soden, Dibelius) - as this is scarcely implied in the context-but of the slaves as shown by their better service (Hofmann, Wohlenberg, Field, etc.). Seneca, in a noble passage, de Beneficiis, iii. I 8-2 $\mathrm{x}$, discusses the question whether a slave can confer a beneficium on a master, and decides that he can: "quidquid est quod servilis officii formulam excedit, quod non ex imperio sed ex voluntate præstatur, beneficium est." 'The Christian writer assumes it without discussion. Yet even if this is the certral meaning, the thought of the divine $\epsilon^{\prime} \in \rho \gamma \epsilon \sigma i a$ may lie in the background: cf. Ep. Diogn.

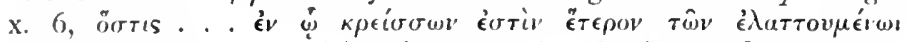

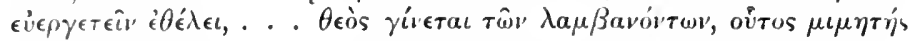
द́ध

àyariroi] they share their faith and have become belovedno longer feared-by themselves: perhaps also with the suggestion "beloved of God." 
3-21. Conclusion. Final warning and exhortation, returning to the thought and often to the very words of $\mathrm{I}^{3-20}$; but there the stress was on the character of the teaching, here on the character of the teachers. Two contrasts underlie the whole: $(a)$ The faithful and unfaithful teacher: the latter loving novelty and controversy, with his eye set on material gain; the former pursuing spiritual aims, loyal to the teaching he has received, with his eye set on the coming of the Lord and on the life eternal. The true and false attitude to riches: the desire for wealth, the source of all evil and the ruin of teachers; the true use of wealth leading to a wealth of good deeds here and eternal life hereafter.

The "words of the Lord Jesus Christ" 3 form the standard for the teaching, and His words about contentment and the danger of the desire of riches ( $\mathrm{Mt} 6^{24-34}, \mathrm{Mk} \mathrm{IO}^{23-25}, \mathrm{Lk}_{1} 2^{15-21}$ $\left.{ }_{1} 6^{19-31}\right)$ may lie at the back of the second contrast, though there is not sufficient verbal similarity to prove a literary dependence.

3-10. Paraphrase. I go back to the warning with which I began. If any teacher sets himself up to teach novel doctrines and does not loyally adhere to sound words-I mean words that come from the Lord Jesus Christ Himself-and to the teaching which is true to real religion, such an one's head has been turned: he has no real knowledge: he is like a delirious patient feverishly excited over this small point and that, fighting with words as his only weapons; and the result is envy, strife, abuse of other teachers, ill-natured suspicions, incessant friction between men whose minds have been confused and who have been deprived of the truth they once knew; they have come to think of religion wholly as a source of gain. Aye, and religion is a source of true gain, it combined with a contented spirit: and we ought to be contented, for we can carry nothing with us when we leave the world, and that is why we brought nothing with us when we came into it. Nay, if we have food for our lifetime and a shelter and clothing, that will be enough for us. Whereas those who set their heart on becoming rich fall into temptations, into dangerous positions, into many desires which are foolish and worse than foolish, fatal, for they lead men to shipwreck and plunge them into death and destruction. For the love of money is proverbially the root from which the whole host of evils springs: and already some teachers through their craving for money have wandered from the safe path of the faith and have fallen pierced through with many a pang and many a sorrow.

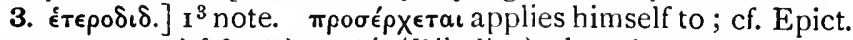

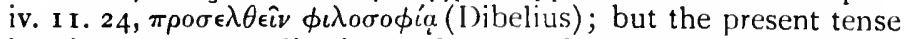
implies constant application and approach to the words of a living and speaking master, and for one already a teacher some word denoting "abiding in" would be more natural. Hence Bentley 
conj. $\pi \rho \sigma^{\prime} \chi^{\prime} \chi_{\ell}$ from $\mathrm{I}^{4}$, and Tischendorf reads $\pi \rho \circ \sigma \dot{\epsilon} \chi \epsilon \tau a \iota ;$ cf.

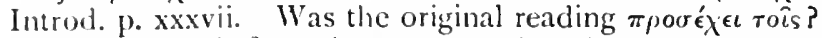

rois rou kupiou] possibly the teaching about the Lord, cf. II $1^{8}$, but more probably "the teaching of the Lord." There is possibly an allusion to some collection of His sayings, cf. $5^{18}$ note, Acts $20^{35}$.

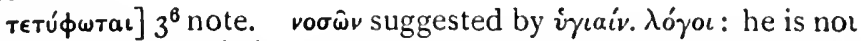
yet dead $\left(5^{6}\right)$ but is in a dangerous state, on the way to death ${ }^{\theta}$;

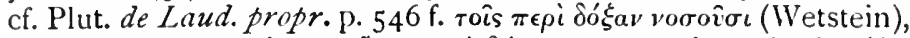

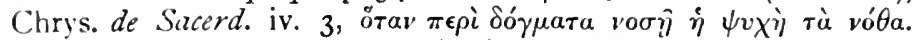

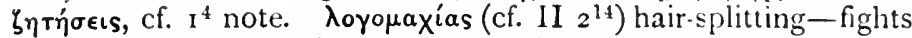
in which words are the weapons and perhaps also the object; there is no reality behind them.

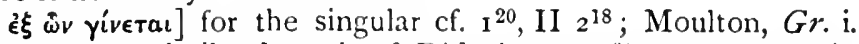
p. 58. For a similar formula cf. Didache, c. 3, $\$$

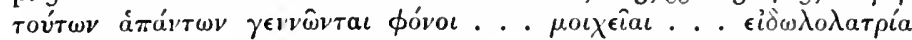

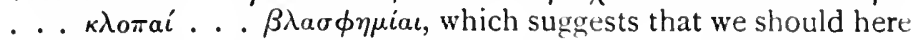
read $\gamma \in v v \hat{a} \tau a \iota$ or $\gamma^{\prime} v^{\prime} \hat{\omega} \nu \tau a \iota$ with D d g m ${ }^{62}$.

$\beta \lambda \alpha \sigma \phi \eta \mu i a l]$ not here of God, but of their rival teachers. inóv.

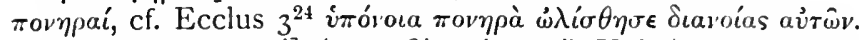

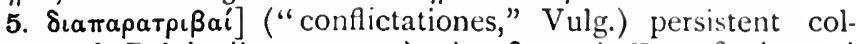

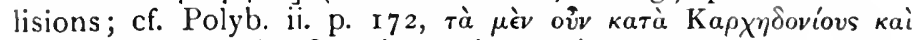

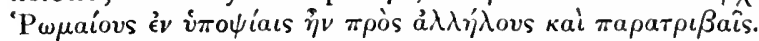

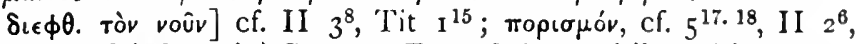
Tit $\mathbf{I}^{11}$, and (Wetstein) Seneca, $E p$. Io8, "qu1 philosophiam velut aliquod artificium venale didicerunt." All the following truths can be illustrated almost verbally from classical writers (cf. Wetstein throughout), and they suggest a conscious modelling on the best Greek teaching.

6. aủrapkeías] "sufficientia," Vulg.; "quod sufficit," Aug.; but the meaning is probably not, "if he has sufficient" (which is stated in $\left.{ }^{8}\right)$, but "if combined with contentment"; cf. Phil 4 ", Prov 13 ,

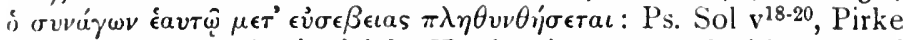
Aboth iv. 3. "Who is rich? He that is contented with his lot."

"'l'he training of a Jewish Rabbi might be even more exacting. This is the path of the Torah. A morsel with salt shalt thou eat, thou shalt drink also water by measure, and shall sleep upon the ground and live a life of trouble while thou toilest in the Torah. If thou doest this, happy shalt thou be, and it shall be well with thee: happy shalt thou be in this world and it shall be well with thee in the world to come." Prrke Aboth vi. 4 (Abrahams, Studies in Pharisaism and the Gospels, c. xiv.).

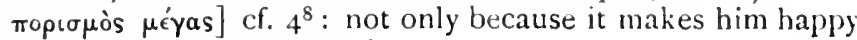
with the little that he has; $c f$.

"Contentment is a constant feast,

He's richest who requires the least" (Barnes), 
but because he is able to enjoy all God's gifts as gifts to himself ;

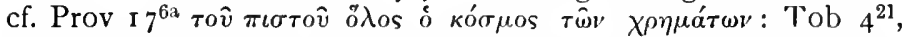

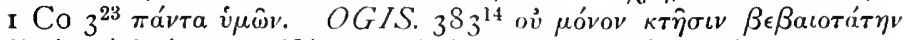

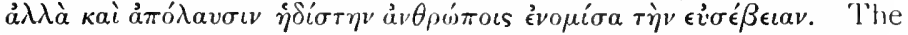
best comment on the verse will be found in T. Traherne's Medi tations, Century I.

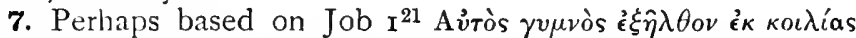

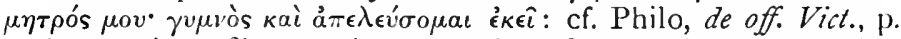

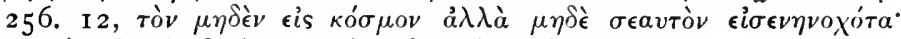

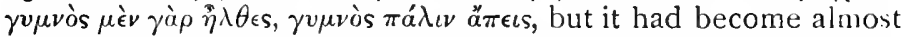
proverbial; cf. also Ecclus $5^{14}$; Seneca, $E p$. I 02 , " non licet plus efferre quam intuleris"; Ovid, Trist.v. 1 4. I2, "Nil feret ad manes divitis umbra suos" (Wetstein). $\dot{\boldsymbol{\epsilon}} \boldsymbol{\xi} \epsilon \nu \epsilon \gamma \kappa \epsilon \hat{\imath} \nu$ suggests "carrying out in burial," Acts $5^{6}$.

ör (if genuine, but cf. W.-H. App. where H. suggests that it is an accidental repetition of "ov" in $\kappa o ́ \sigma \mu \nu$ ), perhaps introducing the quotation "for the proverb says," or implying the Divine ordering of birth as a preparation for the life of a stranger and sojourner on this earth who has to pass through death to his abiding city. Hillard treats ö $\tau \iota$ as neuter of ö $\sigma \tau \iota s$ and translates "wherefore," comparing Eur. Hec. I3, ö кaí $\mu \epsilon \gamma \hat{\eta} s i$

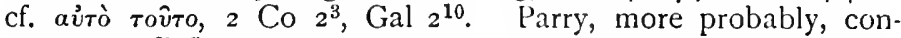
jectures ov $\delta$ " ó $\tau \iota$, "not to speak of being able to carry anything out ;" cf. Introd. p. xxxvii.

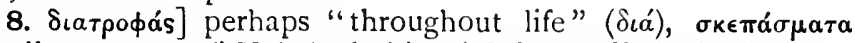
("quibus tegamur," Vulg.), clothing (cf. Gen $28^{20}$ éà $\dot{o}$ кúpıos... $\delta \hat{\omega} \mu$ o ă

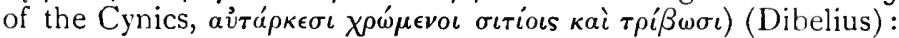
perhaps also "shelter," "homes"; cf. Ecclus $29^{21}$ 'A $\rho \chi \eta े ~ \zeta \omega \hat{\eta} s$

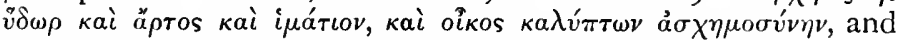

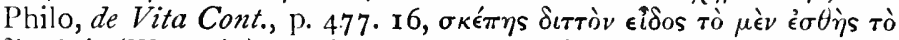

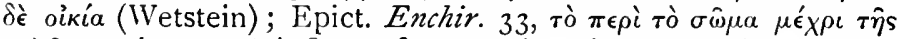

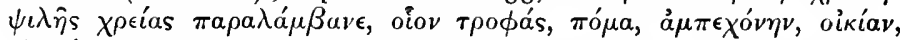
oikeтiav, Marcus Aur. v. 6. 30, quoted on p. xvi.

9. Butí̧ouvi] for the metaphor, cf. $\mathbf{I}^{19}$, and de Aleatoribus, $\S \mathrm{I}$, "aleatores se in lacum mortis immergunt"; $\$$, "aleæ tabula est diaboli venabulum et delicti vulnus insanabile." The whole treatise is a comment on this verse.

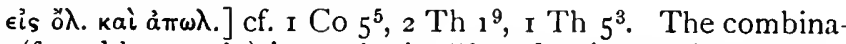
tion (found here only) is emphatic, "loss for time and eternity."

10. pí̧ $^{\prime}$ ] not "a root," which would suggest that the writer was thinkıng of other possible roots (which no doubt there are, .g. jealousy, St. Cyprian, de zelo ac livore, 6 ; pride, Aug. in Joh. xxv. i 6), but "the root" (cf. Field, Ot. Norvic. ad loc.).

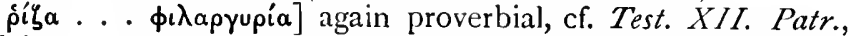
Judah, c. 19, and the Greek saying attributed sometimes to 


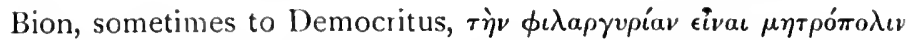
$\pi \alpha \dot{v} \tau \omega \nu \tau \hat{\omega} \nu \kappa \alpha \kappa \hat{\omega} v$, I)iog. Laert. vi. 50 ; Seneca, de Clem. ii. I, "alieni cupiditate, ex qua omne animi malum oritur." Ps.-Phocyl.

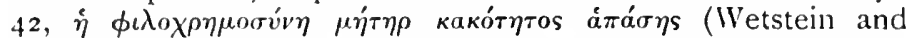
Dibelius). So Philo, De Judice, c. 3, warns a judge against

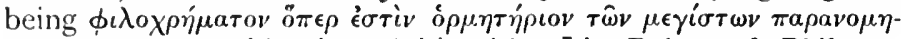
$\mu a ́ \tau \omega v$. The combination of this with v. ${ }^{7}$ in Polyc. ad Phil. c. 4 suggests literary dependence on the epistle.

ódúvats] both actual evils and the pangs of remorse. For the metaphor, cf. Prov $7^{23-27}$. For illustrations, Mk $10^{22} a \dot{a} \tilde{\eta} \lambda \theta \epsilon$

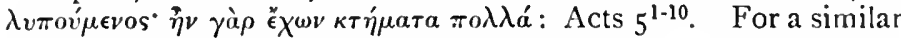
condemnation of "wealthy Ephesus," cf. Pseudo-Heracl. Ep. 8. It is in his address to elders of Ephesus that St. Paul insists that he had coveted no man's silver or gold or apparel, Acts $20^{\mathbf{3 3}}$.

11-16. Paraphrase. But you, who are God's own prophet with a message from $\mathrm{Him}$, turn your back on all such desires and empty discussions : nay, press forward to gain true righteousness, true piety, loyalty, love, endurance, and a patient forlearing temper. Persevere in the noblest of all contests, that of the faith; lay hold once and for all on that eternal life to which you were called-ay, and there were many who witnessed the noble profession of faith that you then made. So then I charge you as in the sight of that God who is the source and sustainer of life to all that lives, and in the sight of Christ Jesus who Himself when at the bar of the Roman Governor made His noble profession, that you carefully keep the command $\mathrm{He}$ gave us free from all stain and all reproach, until the day of the appearing of Our Lord Jesus Christ, which at the right moment $\mathrm{He}$ will unveil to the world, who is the blessed, nay, the One only Sovereign, the King over all who rule kingdoms, the Lord of all who hold lordship over their fellows, He who alone hath in Himself immortality, who dwelleth in light to which none can approach, whom no eye of man ever looked upon, no nor can look uponto whom be all honour and sovereignty for ever. Amen.

Note the stress on life throughout the section. $\tau \hat{\eta} s$ aiwriov

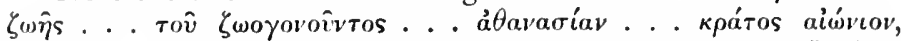
drawing the contrast with the doom of the false teachers of $\lambda \epsilon \theta$ pov каi $a \dot{\alpha} \pi \dot{\omega} \lambda \epsilon \iota \alpha \nu$.

11. äv $\theta \rho \omega \pi \epsilon \theta \epsilon o \hat{u}]$ here and II $3^{17}$ only in N.T. In the O.T. applied to Moses (P's $90^{1}$, Int $33^{1}$ ) and to prophets ( I S $2^{27}$ ),

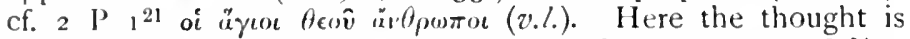
either that of the prophet with a command to carry out, cf. ${ }^{14}$, a message to deliver (cf. ${ }^{20}$ ), or more widely (cf. II $3^{17}$ note) of one who is God's soldier, "The King's Champion" (Pilgrim's Progress, of one Great-(rrace), one whose whole life is lifted above 
worldly aims and devoted to God's service, "non divitiarum homo sed Dei" (Pelagius); cf. Clem. Alex. Quis Dives, c. 4I, where the rich man is advised to submit to the guidance of some "man of God"; and Philo, de gigant. 6I, $\theta \epsilon o \hat{v} \delta \grave{\epsilon} a ̈ \nu \theta \rho \omega \pi o$ iє $\rho \epsilon \hat{\imath}$

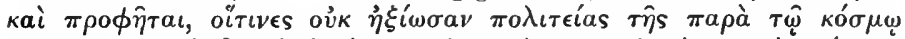

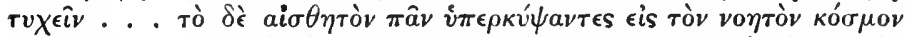

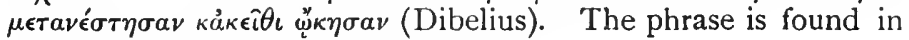
Pagan magical formulæ (Nägeli, p. 49).

$\left.\phi \epsilon \hat{\mathbf{u}} \epsilon \ldots . \delta \delta^{\prime} \omega \kappa \epsilon\right]$ cf. II ${ }^{22}$. The virtues chosen are the central Christian virtues, first towards God, then towards men

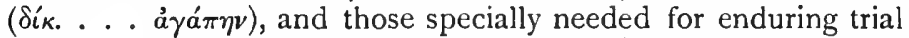
$\left(i \pi \circ \mu\right.$.) and the opposition of false teachers $\left(\pi \rho a \ddot{u} \pi a \theta\right.$., cf. II $2^{25}$, and contrast 4.5 supra).

$\pi \rho a \ddot{\pi} a \dot{\theta} \epsilon \iota \alpha \nu]$ here only in N.T. but found in Philo, de Abr. $\$ 37$;

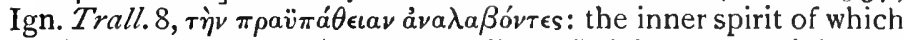
$\pi \rho a{ }^{\prime} \eta \eta$ s is the outcome ("mansuetudinem," Vulg.; "tranquillitatem animi," Ambros.). Ambrosiaster draws out the incompatibility of the love of money with each of these virtues ("quomodo autem fieri potest ut avarus fidelis sit, qui operibus negat quod verbis fateri videtur? unde autem amator fraternitatis, cujus manus sunt avidæ? quomodo vero patiens qui semper ad aliena se tendit? aut quatenus quietem animi possit habere, qui die nocteque aviditate cupiditatis incenditur ?"); Liddon, the way in which these would destroy that love.

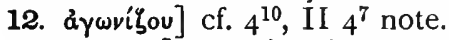

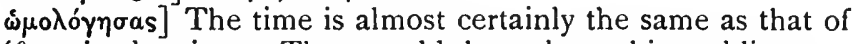
$\epsilon^{\prime} \kappa \lambda \eta^{\prime} \theta \eta s$, i.e. baptism. That would have been his public confession (cf. Ro ${ }^{\circ} \circ^{9}$ ) of faith in Christ. The phrase $\dot{\eta} \kappa . \dot{\delta} \mu \nu \lambda \sigma \gamma$. is applied to the confession of a martyr at his death in Martyr. Ign. Antiochene Acts, c. 4 .

13. Cf. $5^{21}$. Here the appeal is to God and Christ as those in whom he had professed faith at Baptism, who are strong enough to support him in all persecution, and who will judge him at the final judgment.

There may be a semi-quotation of some Baptismal formfaith in God, maker of all things, and in Jesus Christ, as King who is to come again.

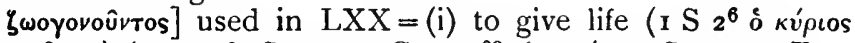

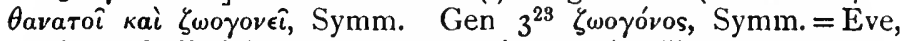
mother of all living, Encyc. Bibl. i. p. 6I); (ii) to save alive, $\operatorname{Ex~}_{1}{ }^{17-22}, J g 8^{19}$ etc. Hence the thought here may include (i) God

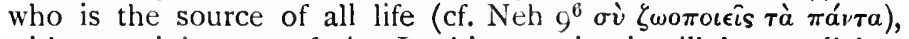
with a reminiscence of $4^{4}$. In this meaning it will be parallel to the credal expansions of the Baptismal formula; cf. Justin $M$.

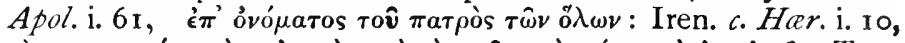

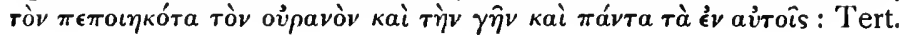


de Prescr. 36, " $11 n$ um Deum novit, creatorem universitatis." In

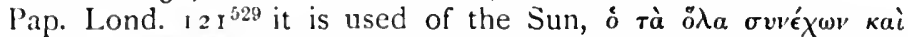
$\zeta \omega o$ ove $\omega v$ (M.M.s.v.). (ii) God who can protect you in all danger

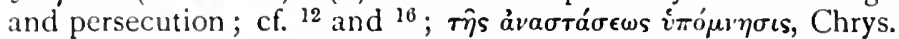

$\epsilon \dot{\epsilon}$ п. П.] not "in the time of," though that is supported by Ign. Trall. 9, Smyrn. I, and expanded in Magn. I I into '́v kaıp⿳亠丷厂 Tiेs $\dot{\eta} \gamma \epsilon \mu o v i a ; \Pi$. П.: but there stress is laid on the historical reality of the facts, which is not in question here; here it is part

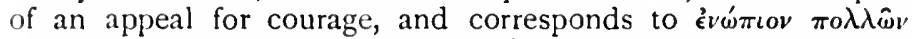

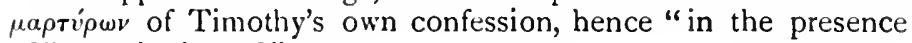
of," "at the bar of."

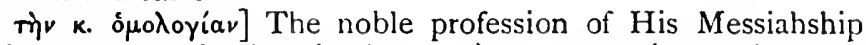

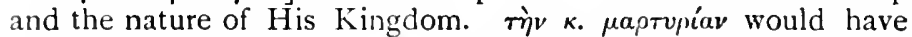
been more natural, but he wishes "to mark the essential identity of the confession which Timothy might soon have to maintain with the Lord's own confession" (Hort on Rev $\mathrm{I}^{2}$ ) and with that which he had already made ${ }^{12}$.

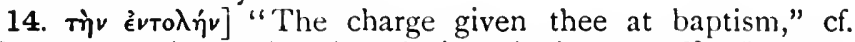

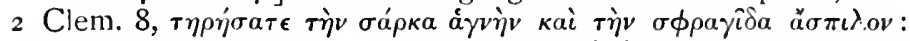
perhaps also more widely "the whole Christian commands"; cf. $1^{4} \tau \hat{\eta} s \pi \alpha \rho \alpha \gamma \gamma \epsilon \lambda i \alpha s, 1^{18}$. St. Cyril of Jerusalem (Cat. v. 13) para-

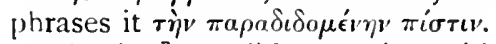

$\ddot{\alpha} \sigma \pi \iota \lambda o v$ ] possibly agreeing with $\sigma \epsilon$ (cf. Jas $\mathrm{I}^{27}, 2 \mathrm{P} 3^{14}$ ), but probably with $\dot{\epsilon}^{\prime} \tau o \lambda \eta^{\prime} v^{\prime}$ cf. Job $15^{16}$ (Symm.) of the heavens, Eph $5^{2 \tau}$ of the Church. The commands must be kept clear, not explained away, and yet presented with such tact as not to cause offence.

émıqueias] cf. Tit $\mathbf{2}^{\text {II }}$ note. The thought of the dawning of light which will test the minister's work and character is prominent here; cf. $\delta \epsilon^{\prime} \xi_{\xi \epsilon}{ }^{15}$, I Cor $4^{5}$.

15. kalpois isiors] cf. Tit $\mathrm{I}^{3}$ note. This description of God is full of O.T. reminiscences and is perhaps based on some doxology in use in the synagogue. The stress is laid on the

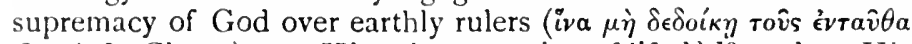
$\beta a \sigma\left(\lambda \epsilon \hat{\text { s }}\right.$, Chrys.): on His sole possession of life ${ }^{12.13}$, and on His superhuman Majesty. These qualities were brought out in the $O$.'T. in contrast to the heathen gods, here also in contrast to earthly kings, especially to the growing cult of the Roman Emperors. Dibelius quotes the Acts of the Scillitan Martyrs, "jura per genium domini nostri imperatoris," "Cognosco dominum meum, regem regum et imperatorem omnium gentium." The Greek metaphysical conception of God may also influence the description (cf. ${ }^{11}$ note).

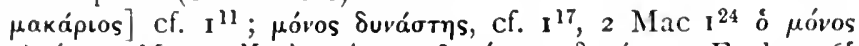

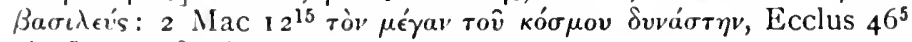
тòv vँษ 


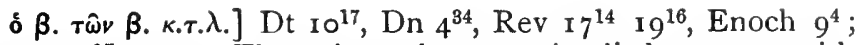
cf. sup. I $^{17}$ note. There is perhaps an implied contrast with Pontius Pilate, the temporary, the unjust, delegate; cf. Marlyr.

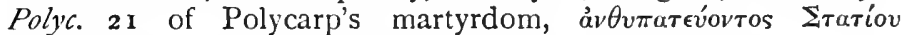

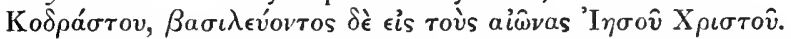

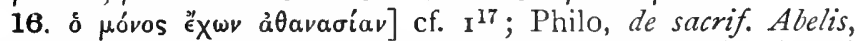

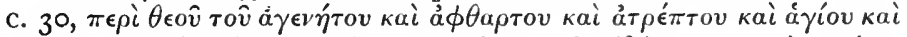

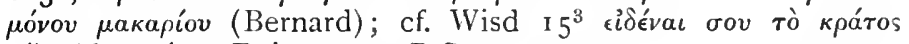
píla àtavarias: Deissmann, B.S., p. 293.

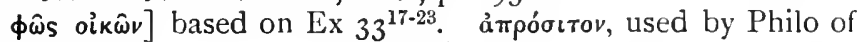

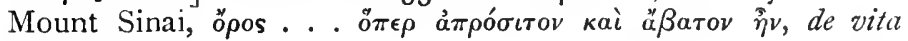
Mosis, iii. 2.

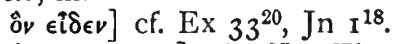

i. . a $\left.\mu \eta^{\prime} v\right]$ cf. ${ }^{17}$. The thought of the First and of the Second Advent alike suggests a doxology to his mind.

17-19. Advice to the rich.

Paraphrase. I have warned teachers against the desire for riches; but there are other members in your church rich in this world's good, and they will need your guidance. Bid them not to be purse-proud or conceited, not to set their hopes for hereafter on so uncertain a reed as riches, but on God; and Him they should try to imitate; for $\mathrm{He}$ has all the riches of the whole world, and He gives them out liberally to us men that we may enjoy them thoroughly; so they should do good like Him; they should have for their riches a store of good deeds: they should be quick to give to others, ready to share with their friends : in this way they store up true treasures for themselves which form a firm foundation on which they can build for the future; such use of wealth will help them to lay hold of the only life that is worthy of the name.

The paragraph is awkwardly placed here, breaking the connexion between ${ }^{16}$ and ${ }^{20}$; von Soden suggests that it has been accidentally misplaced, and should come after ${ }^{2}$; but it is natural advice to a church in a rich city like Ephesus (cf. Ac $19^{25}$, which shows that St. Paul's teaching had been attacked there, as endangering the wealth of the trade); the thought may have been suggested by 9.10 ; and it is more appropriate after these verses than they would be after it. There may be also consciously a link with ${ }^{11-16}$ in the thought of eternal life (cf. note there). That thought suggests to the writer's mind the special danger in which the rich are of losing eternal life ${ }^{19}$.

The thought and language may be based on Our Lord's words, cf. Mt $6^{19}, \mathrm{Lk}_{12}^{16-21} \mathbf{1}^{9}$. But the thoughts of the uncertainty of riches, of the treasure laid up in heaven by good use of wealth here, even that of the imitation of God in the use 
of wealth are thoroughly Jewish (cf. Philo, de Josepho, c. 43, and Abrahams, Studies in Pharisaism and the Gospels, c. xiv.), and found in pagan thought; cf. the epitaph in Or. Henz. 6042, bene fac, hoc tecum feres. So Dill, Roman Society from Nero, p. I90, "Seneca enforces the duty of universal kindness and helpfulness by the example of God, who is bounteous and merciful even to the evil-doer" (de Benef. iv. 5, iv. 26, iv. 28), and p. 232, "Herodes used to say that the true use of money was to succour the needs of others; riches which were guarded with a niggard hand were only dead wealth." Clement of Alexandria's Quis Dives Salvetur is an interesting commentary on the section (especially c. r6), but shows no knowledge of it.

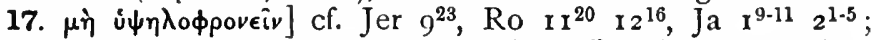

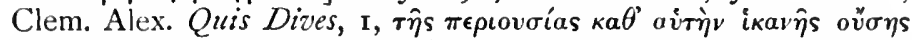

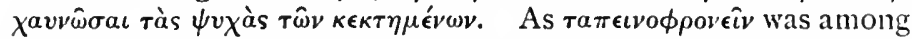
the Greeks a term of reproach but in the Bible a virtue, so ư $\downarrow \lambda \circ \phi \rho o v \epsilon i v$ was a term of praise and becomes a reproach (Wohlenberg from Hofmann).

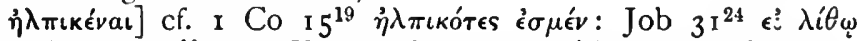

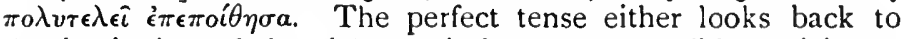
the beginning of the rich nran's hopes, or possibly anticipates his feelings at the mapovoia: "Alas, alas, I have placed my hopes on that which has failed me!" cf. II $4^{8} \dot{\eta} \gamma a \pi \eta \kappa o ́ \sigma \iota$.

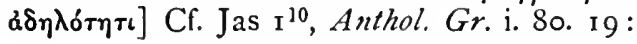

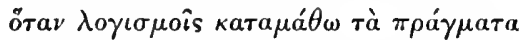

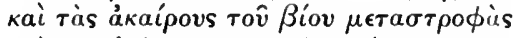

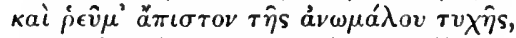

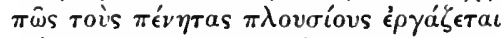

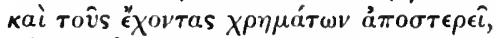

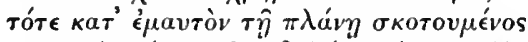

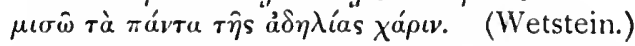

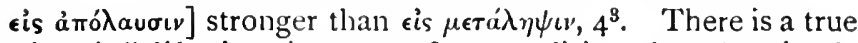
"apolaustic" life, but it comes from realizing that the simple

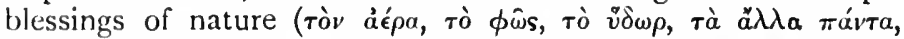
Chrys.) are gifts to each from God; cf. Traherne's Meditations,

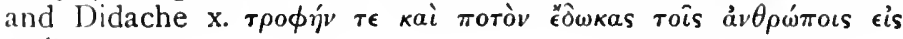

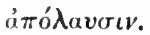

18. ả $\gamma a \theta 0 \epsilon p \gamma \epsilon \hat{v}]$ like God Himself, Acts $14^{17}$ ả $\gamma a \theta o v \rho \gamma \hat{\omega} v$. . .

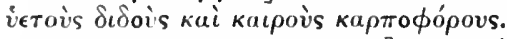

$\epsilon u ̉ \mu \epsilon \tau a \delta$ órous, коเvшиเкоús] The distinction is not clear; either, quick to give away to others in charity (singulatim, Bengel), cf. Ro $12^{8}$, Eph $4^{28}$, I Co $13^{3}$, and ready to share with one's friends that which is one's own (cum multis, Bengel), e.g. at the a $\gamma a \dot{\pi} \pi \eta$, cf. Gal $6^{6}$, Heb $13^{16}$; or, єủ $\mu \in \tau a \delta$., of accion, "open-handed,"

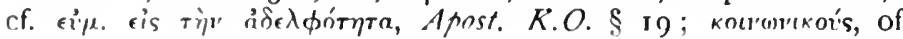


demeanour and temper, "gracious," with true sense of human fellowship, the antithesis of $v \psi \eta \lambda$ i

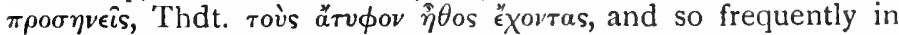

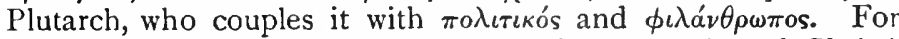
the Church's use of money, cf. Harnack, Expansion of Christianity, Eng. tr. I. ii. c. 3 .

19. a $\pi 0 \theta \eta$ oaup.] $\mathrm{cf} . \mathrm{Mk} 10^{21}, \mathrm{Mt} 6^{20}$. The thoughts of the true treasure and the true foundation lie close together in the

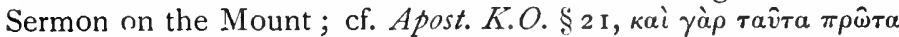

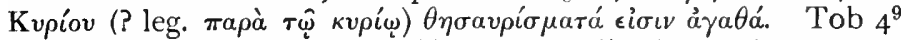

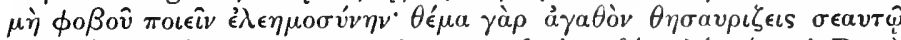

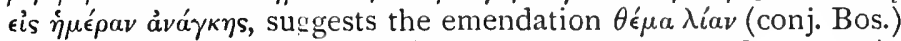

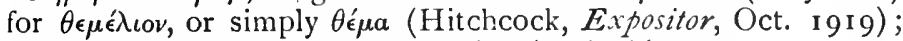

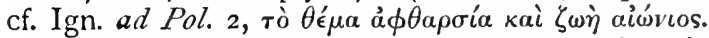

iva $\epsilon \pi \imath \lambda \dot{\beta}$.] cf. ${ }^{12}$. This true life would be laid hold of here and now, as they enter into the true life of love, cf. $\mathrm{Jn} 17^{3}$.

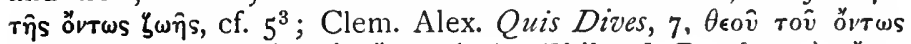
ö้

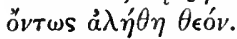

An interesting Rabbinic illustration is found in Bab. Bath. $1 \mathrm{I} a$. It happened to Monobaz that he dispersed his wealth and the wealth of his fathers on alms in time of famine. His brethren gathered round him and said, "Thy fathers laid up treasure and added to their fathers' store, and dost thou waste it all?" He answered, "My fathers laid up treasure below; I have laid it up above. . . My fathers laid up treasure of Mammon; I have laid up treasure of souls. . . . My fathers laid up treasure for this world ; I have laid up treasure for the world to come."

20, 21. Conclusion. Very probably added by St. Paul with his own hand, $2 \mathrm{Th} 3^{17}$, summing up the thoughts of $1^{3-11} 4^{1-10}$ 6-10.

Paraphrase. O Timothy, it is to you that I must look. Remember the truth is a sacred trust which Christ has left with us, and $\mathrm{He}$ will come to ask it back. Keep it then jealously; avoid all empty argumentations, all balancing of casuistical problems: they have nothing to do with religion, they add nothing to it, they spoil its simplicity, though some who falsely claim to special knowledge lay stress on them. These teachers, though they assert their proficiency in knowledge, have wholly missed the central truths.

May God's grace be with you all.

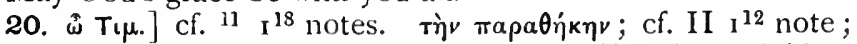

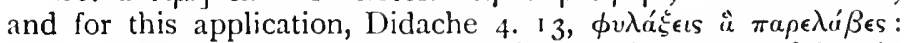

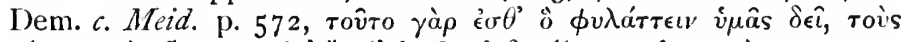

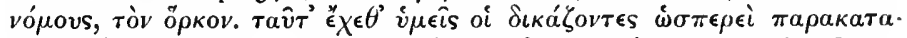

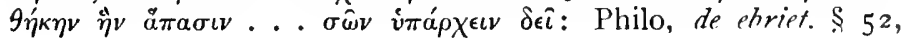




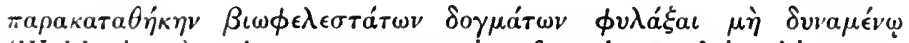
(Wohlenberg). An exact exegesis of each word in this verse will be found in Vincent. Lerin. Commonitorium, 22.

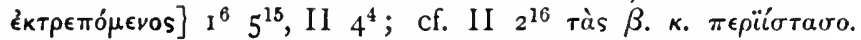
This last passage makes it probable that the meaning is not "turning your back on those who so talk," but "refusing to adopt their methods."

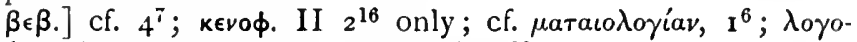

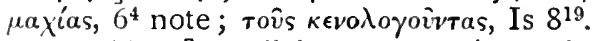

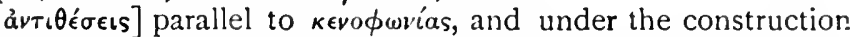

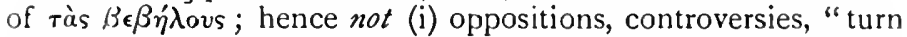
aside from opponents and do not argue with them"; cf. II $2^{25}$

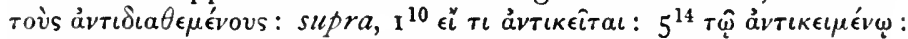

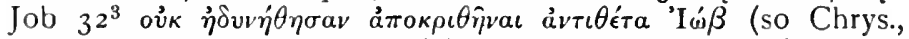

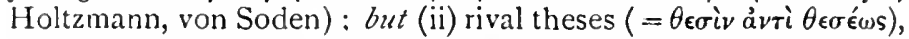
sets of antitheses (cf. Lucian, Mort. D. x. 373, $\dot{\alpha} \pi \circ \theta 0 \hat{v} \tau \hat{\omega} v$

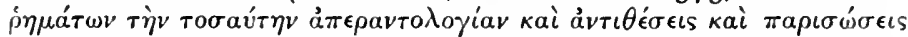

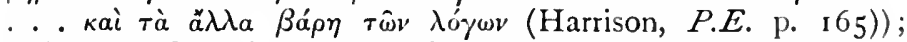
either the Gnostic contrasts between the O.T. and the New, which found their fullest expression in Marcion's "Antitheses," cf. Tert. $a d v$. M. i. I9, iv. I, "opus ex contrarietatum oppositionibus Antitheses cognominatum et ad separationem legis et evangelii coactum"; but this is not consistent with the stress on the Jewish law implied in $\mathbf{i}^{6 \cdot 10}$ : or, more probably, "the endless contrasts of decisions, founded on endless distinctions, which played so large a part in the casuistry of the scribes as interpreters of the law" (Hort, Judaistic Christianity, p. I40). It is identical with "the tradition of the elders" which the Lord denounced, and of which St. Paul had been zealous before his conversion ( $\mathrm{Ik}^{3}$, Gal ${ }^{14}$ ), afterwards embodied in the Halacha; cf. $4^{7}$, II $3^{8}$ note.

Tîs $\psi$. $\gamma \nu \omega \dot{\omega} \sigma \epsilon \omega s$ (contrast $\gamma \nu \hat{\omega} \sigma \iota \nu$ a $\psi \epsilon v \delta \hat{\eta}$, Wisd $7^{17}$ ). The opponents must have claimed a special knowledge, but this night apply to the early stages of Gnosticism; cf. I Co $8^{2.3} \epsilon i$

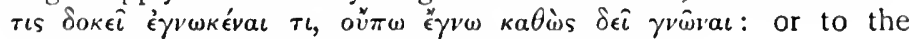
Rabbinical pride in knowledge, $\mathrm{I}_{\mathrm{k}} \mathrm{II}_{1}^{52}$, Ro $2^{20}$.

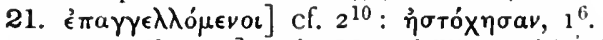

$\left.\dot{\eta} X a ́ p \iota s \mu \in \theta^{\prime} \dot{u} \mu \hat{\omega} v\right]$ as in II and 'l'it the blessing is for the whole Church; but there is considerable MSS support for $\mu \in \tau a$ бoin: cf. Introd. p. xxxvii. 


\section{TIMOTHY}

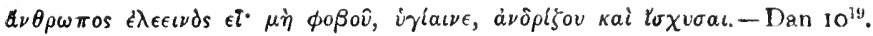

Historical situation.-(i) St. Paul.-St. Paul is a prisoner in Rome $\left(1^{3.16} 2^{9}\right)$ and has been so for some length of time, during which he has received a visit from an Ephesian Christian, Onesiphorus, who had found him out, though apparently with difficulty, and had cheered him with frequent visits $\left({ }^{16}\right)$. The charge laid against him is not stated: it may have been of being a Christian $\left(2^{10}\right.$, cf. I P $\left.4^{16}\right)$, perhaps that of some offence against

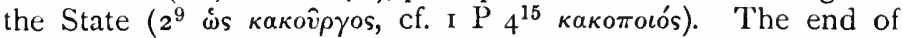
the trial is in sight : so he writes to his beloved son Timothy, to bid him farewell, to exhort him to be ready to share suffering for Christ's sake, and to impress upon him the duty of choosing faithful ministers to whom to hand on the true teaching, and to lay stress upon the true characteristics of such teaching. This is all that we can say, if $4^{9-21}$ is to be separated from the Epistle as embodying fragments of letters of an earlier date (cf. p. xxxii). If, however, we can assume the integrity of the Epistle, the further object is to request Timothy to join him speedily in Rome and share his sufferings there $\left(4^{9-21}\right.$, cf. $\left.\mathrm{I}^{8} 2^{3}\right)$. There is no certain indication of the place to which the letter was sent, but $1^{18}$ makes Ephesus probable.

(ii) The Church at Ephesus.-Very little light is thrown on the circumstances of the Church at Ephesus. Timothy is in charge of it, as the Apostle's delegate, and is expected to remain there, so that the Epistle seems to point to the position of a permanent rather than that of a temporary delegate: he has to do the work of an "Evangelist," and it is described by the indefinite title of "ministry" $\left(4^{5}\right)$. He has had the Apostle's hands laid upon him $\left({ }^{6}\right)$, apparently for this special task : his duty is to keep the deposit of truth, to hand it on to others, to control their teaching, to exercise discipline over the members $\left(4^{2}\right)$. No mention is made of other grades of ministers or of the details of the services. But there are false teachers, tickling the ears with novelties, appealing specially to women, corrupted in mind, disloyal to the faith ; their teaching tends to a low standard 
of morality and is likely to spread $\left(2^{16}\right)$. Of its nature there are three hints : (i) they deal with well-known fables (roùs $\mu$ v́tous, $4^{4}$ ), i.e. probably stories from the Jewish Haggada (cf. Introd. p. xvii).

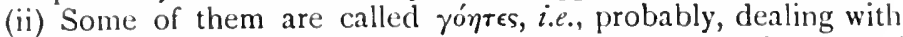
magical charms, like Simon Magus and Elymas and the sons of Scæva a Jew at Ephesus (Acts I9) : so this, too, may spring from Jewish influences, and they are compared with the Egyptian magicians who opposed Moses. (iii) Two of them assert that the Resurrection is past $\left(2^{18}\right)$, probably influenced by doubts about the Resurrection of the body, and misrepresenting St. Paul's teaching (Ro 6) as meaning only a resurrection to spiritual life in this world. This is the tenet most akin to later Gnosticism (vid. notes ad loc.), but it might also be suggested by Sadducean teaching. There is then nothing to separate them from the teachers referred to in $\mathrm{I} \mathrm{Ti}$ and $\mathrm{Tit}$.

Date.-If we assume the integrity of the whole, Paul has lately been travelling through Asia Minor and Greece with a band of fellow-travellers, including Demas, Crescens, Titus, Luke, Tychicus, Erastus, Trophimus; but all have now gone different ways except Luke, who alone is with him: he has once been put on his trial and has made his defence: he has been left alone without any human aid, but the Lord has protected him, If we further assume the completeness of the Acts as a record of St. Paul's travels at this time, it seems impossible to fit in all these allusions with the data there: it becomes necessary to assume that St. Paul was released from the imprisonment of Acts 28 (cf. Introd. p. xxx), that he travelled freely in the East after it, was arrested again and is now suffering a second imprisonment which ended in his death, probably in A.D. 64. If, on the other hand, $4^{9-21}$ are earlier notes, all the data in them must be put aside; and the letter might have been written at the end of the imprisonment of Acts 28, not long after the Third Group of Letters; cf. Introd. p. xxii ff.

Spiritual value.-The importance of the Epistle is not great doctrinally or ecclesiastically: doctrinally, indeed, it seems to give justification for prayer for the dead ( $x^{18}$ note); and it gives the fullest statement in the N.T. of the inspiration of the O.T. and of its primary value to a Christian teacher : ecclesiastically it shows the value attached to the imposition of the Apostle's hands and to a succession of carefully chosen ministers as a means of securing the tradition of sound teaching. But its main interest is that of character, and two portraits may be traced in it.

(i) The portrait of the ideal Christian minister. He is, like His master, to reproduce the features of Isaiah's ideal of "the suffering servant": he is to be patient, gentle, hopeful, interceding for his opponents $\left(2^{24}\right)$; he is to be like a soldier, un. 
entangled with civil duties $\left(2^{3}\right)$; like an athlete, obeying loyally the rules of the contest $\left(2^{5}\right)$; like a husbandman, toiling hard and earning his reward $\left(2^{6}\right)$; like a tradesman, skilfully cutting out his goods $\left(2^{15}\right.$ ?) ; like a fisherman, trying to catch back those who have been caught by the devil ( $2^{26}$ ?). He needs long-suffering, yet persistence in pressing his message in season and out of season $\left(4^{2}\right)$, sobriety of tone $\left(4^{5}\right)$, courage to face suffering $\left({ }^{8} 2^{3} 4^{5}\right)$; he has to aim at the great central virtues, to keep in touch with all sincere Christians $\left(2^{22}\right)$, so as to become a vessel which his Master will always find ready to $\mathrm{H}$ is hand $\left(\mathbf{2}^{21}\right)$; he has to rekindle again and again, "to keep at white heat," the grace given by ordination, remembering that it was the gift of love, of strength, of self-discipline $\left(\mathbf{r}^{6}\right)$; he has to rely upon the Holy Spirit that dwells in him $\left(1^{14}\right)$. In teaching he has to avoid idle speculations and restless innovations, to be loyal to the truth, and to take for guidance: $(a)$ the example of the Apostle's life $\left(3^{10}\right) ;(b)$ the outline of the Apostle's teaching $\left({ }^{13}\right)$; (c) the O.T. Scriptures, which are not only able to make men wise unto salvation, but are also a guide for the discipline of others $\left(3^{16.17}\right)$. His aim is to make each person a man of God thoroughly equipped for every good work $\left(3^{17}\right)$.

(ii) The portrait of the Christian Teacher face to face with death, with his work finished. It is, "Testamentum Pauli et rygnea cantio" (Bengel), and should be compared with the farewell words of Moses (Dt $3^{1^{1-8}}$ ), of Joshua (c. 23), of David ( $1 \mathrm{~K}^{1-8}$ ), of Our Lord Himself (esp. John 13-16), with 2 Peter, and with St. Paul's own farewell to the elders of Ephesus (Acts 20 ). $\mathrm{He}$ is ready to endure what suffering still remains $\left(2^{10}\right)$; but his thoughts turn back to the past or forward to the future. He looks back to the religion which his ancestors had taught and he himself had learnt from childhood $\left(\mathrm{I}^{3}\right)$, to the commission he had received to preach the Gospel $\left(\mathbf{I}^{11}\right)$, to all his sufferings in the past, to God's protection of him through them all $\left(3^{11}\right)$, to the fight which he has fought; he is grateful for the kindness of friends, invoking God's blessing upon them $\left(\mathrm{I}^{16}\right)$, for the loyalty of his loved son $\left(3^{10}\right)$, sensitive to the failure of others to support him, but leaving their punishment to God $\left({ }^{15}, c^{15} 4^{16}\right)$. But his eyes are mainly on the future: he foresees difficult days $\left(2^{17} 3^{1}\right)$, he tries to prepare his successor to face them: he is prepared to depart himself ("de prospectu ejus exultans scribit," Tertullian, Scorp. 13): he has deposited his all in God's care, and hands on the truth as a deposit to his successor

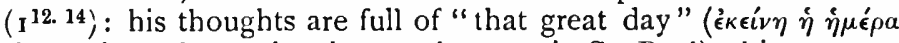
three times here, elsewhere only once in St. Paul): his eyes are turned to the light (cf. $\mathrm{I}^{10}$ ), to the bright shining of the Lord's coming : he looks forward with confidence to a crown of righteous. 
ness, and to a life beyond death: his faithful saying is a hymn about life through death with Christ $\left(2^{11}, \mathrm{cf} . \mathrm{I}^{10}\right)$ : he is to the end that for which the will of God had chosen him, an Apostle

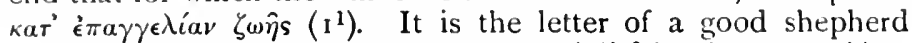

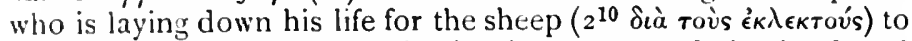
one whom he is training to be in his turn a good shepherd and to lay down his life for the Gospel's sake, inspired by the thought of "the Good Shepherd" who had laid down His life and had risen from the grave $\left(2^{8}\right)$, to be the strength of all who should suffer for His sake. ${ }^{1}$

Analysis.-The subject-matter oscillates between the thought of St. Paul's own position, with which it begins (c. I) and ends (c. 4), and that of Timothy which occupies the central part (cc. 2,3 ); but the two are not kept separate and often interlace.

A. 1 1.2. Greeting.

3-18. St. Paul's feelings and position:

3-5. Thanksgiving for Timothy's past affection and desire to see him again.

8-18. Appeal to Timothy:

(I) To stir up the gift given him by the laying on of St. Paul's hands ( ${ }^{6.7}$ ).

(2) Not to let St. Paul's imprisonment dishearten him, but to be ready to face suffering himself, remembering Christ's conquest of death, and St. Paul's own sufferings and unswerving faith in God's readiness to keep all that he has entrusted to His care ( $\left.{ }^{8-12}\right)$.

(3) To hold fast the truth that St. Paul has taught him (13.14). These appeals enforced by two recent experiences of St. Paul's: as a warning-his desertion by all in Asia $\left({ }^{15}\right)$ : as encouragement-the boldness and kindness of Onesiphorus at Rome (16-18).

B. $2^{1}-4^{5}$. Timothy's duties.

In relation to himself:

To be strong-

(I) To hand on his teaching to others ( ${ }^{1.2}$ ).

(2) To be ready to face suffering and endure toil, like a good soldier, a good athlete, a good husbandman $\left({ }^{3.7}\right)$; constantly to bear in mind-

(a) The Risen Christ, who has enabled Paul to endure suffering and imprisonment for the sake of the elect $\left({ }^{8-10}\right)$;

(b) The faithful saying - with its encourage-

1 Adapled with some alteralions from my own arlicle in H.D.B. 
ment to all who share Christ's death and warning to all who deny Him $\left(^{(1-13)}\right.$.

In relation to the teachers to zohom he hands on the deposit:

To warn them against empty wranglings $\left({ }^{14}\right)$ : to be himself a true worker avoiding such discussions which will only lead to impiely and harm, as is seen already in the teaching of Hymenæus and Philetus (15-18): to remember the true foundation-God's own knowledge of His own, and their abstaining from iniquity $\left({ }^{19}\right)$. To keep himself pure, to avoid youthful impulses, to aim at the central virtues $\left({ }^{20-23}\right)$ : to avoid foolish discussions and contentions; to be a true servant of the Lord, gentle, skilful in teaching, hopeful for his opponents $\left({ }^{23-26}\right)$. Times are hard: there are many, and there will be more, whose whole standard is based on selfishness and pleasure $\left(3^{1-5}\right)$. There will be silly teachers who will oppose the truth, as Jannes and Jambres did Moses. Timothy must avoid all such, and their folly will soon be exposed (1-9.13). Timothy has been loyal to him in the past and shared all his sufferings, and must not expect to escape persecution himself $\left({ }^{10-12}\right)$. Let him be loyal to the teachers who taught him in his youth, and hold fast to the Scriptures which can make him wise and able to do his work as a teacher $\left({ }^{14-17}\right)$. He must preach boldly, persistently, however unwilling people are to listen to the truth $\left(4^{1-4}\right)$ : must be sober, ready to suffer, carrying His ministry out to the full $\left({ }^{5}\right)$.

C. St. Paul's own position.

All this is necessary, because St. Paul's own end is approaching: he has done his work: he can look forward in confidence to the award of the righteous Judge ( $\left.{ }^{6-8}\right)$.

9-18 Appeal to Timothy to come speedily. Details about his companions and his own recent experiences.

19-21 Special greetings to and from individuals : further details about his companions: more pressing appeal to Timothy to come to him.

22 Salutation to Timothy and to those with him.

With the exception of the Final Salutation $\left(\mu \epsilon \theta^{2} \dot{v} \mu \hat{\omega} \nu\right)$-which 
may possibly have been added when the Epistle was made canonical-the whole is strictly personal, and the note in $\mathbf{2}^{7}$ emphasizes the personal, almost esoteric, character of the advice given. There is scarcely any section which could have been intended to be read publicly when the Church met.

i. 1, 2. Address and Greeting.-Paul to Timothy, his wellloved son, these: Paul writing with authority as one who has received his commission from Christ Jesus, through no choice of his own but by the will of God, who chose him because $\mathrm{He}$ had promised life to the world, the life which was realized in Christ Jesus, and who needed men to tell of that promise. I pray God the Father and Christ Jesus Our Lord to give you grace for your work, help in your difficulties, peace in your heart.

As in $I$, the address is partly official and authoritative, as he wants to strengthen Timothy's authority (ámóorodos), partly personal and affectionate; and this second element is stronger

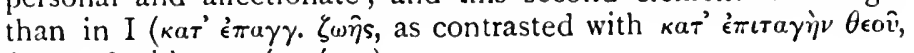

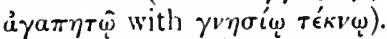

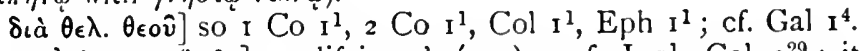

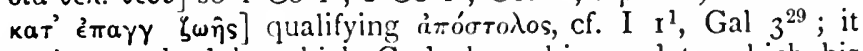
gives the standard by which God chose him and to which his

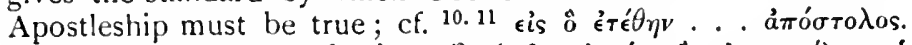

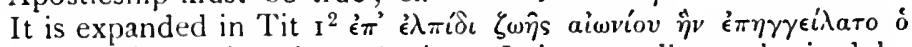

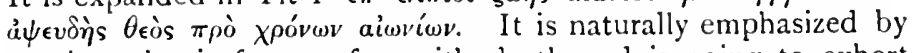
a writer who is face to face with death and is going to exhort Timothy to face it too $\left(2^{11-13}\right)$; but the thought is not only of life beyond the grave, but of a life which begins here and persists through death; cf. ${ }^{10}$ and $\mathrm{I}_{4}^{8}$.

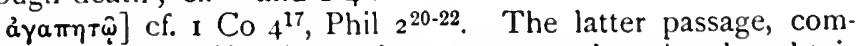
bined with ${ }^{15} 4^{11.16}$ infra, perhaps suggests that the thought is not only "loved," but loved as an only son is loved; the only

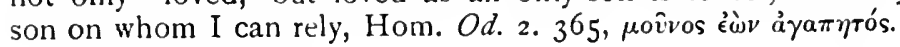

2. Cf. I $\mathrm{I}^{2}$ notes.

3-ii. 13. Thanksgiving to God for Timothy's past life, and appeal for renewed efforts, for courage to face danger, and for loyal adherence to the apostolic teaching.

3-5. Thanksgiving-called out by (a) the writer's own feelings and memory $\left({ }^{3.4}\right)$, and $(b)$ by some recent reminder of Timothy's faith $\left(^{5}\right)$.

Paraphrase. My first word must be to thank God-that God whom nyy forefathers worshipped and whom I worship with a pure conscience-a thanksgiving which springs up in my heart whenever I make mention of you, as I never fail to do night and morning in my prayers; for I have a yearning to see you once more, as I remember the tears you shed at our parting: if you 
could only come, my happiness would be complete. And now I have a special ground of thankfulness in the recent reminder of the sincerity of your faith - a faith which you too have inherited, for it dwelt first in your grandmother Lois and in your mother Eunice, aye, and I have had many and many a proof that it dwells equally in you.

This section has striking verbal resemblance with Ro $\mathrm{I}^{8-12}$ (cf. also I Th $\mathrm{I}^{2.3} 3^{6}$ ); but there is no reason to suspect deliberate imitation by a writer copying St. Paul (so Holtzmann), as the thought is common in literary correspondence of the time; cf. J. A. Robinson on Eph., Additional Note "On some current Epistolary Phrases."

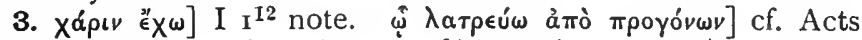

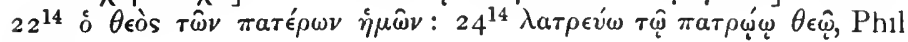
$3^{4-6}$.

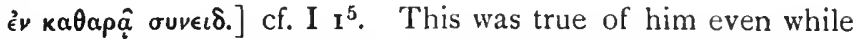
a Jew ; cf. Acts 231. The sense of the real continuity of the Christian with the Jewish faith is constant in St. Paul ; cf. Gal 3 passim, $6^{16}$, Eph $1^{1-11}$, Ro ${ }_{1}{ }^{13-24}$.

As in $\mathrm{I} \mathrm{I}^{3}$ the construction is not clear: for what does he thank God ? probably for 'Timothy's life and loyalty. Es . . Ë $x \omega \omega$ is almost equivalent to "when," "as often as," but adds the thought of the correspondence of the thankfulness with the thought of

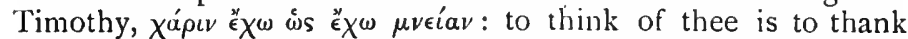
God for thee; to think more is to thank more; to think every day is to thank every day.

vukтòs kai ì $\mu$ ́́pas] either with prec. "in my evening and morning prayers," cf. I $5^{5}$; or with seq. "all night and day longing to see you," cf. I Th $3^{10}$. The balance of the sentence supports the latter construction.

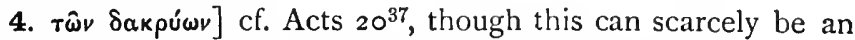
allusion to that scene. "Lacrimre flos cordis" (Bengel).

$\pi \lambda \eta \rho \omega \theta \hat{\omega}]$ perhaps to be joined closely with following: "that I may be filled with joy by the receipt of the reminder which your coming would give" (so R.V. margin, W.-H.); or úmó $\mu v . \lambda a \beta \omega ́ v$

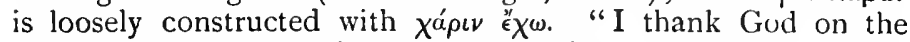
recent receipt of a reminder of your faith." This inuplies that he had lately heard news about Timothy, $\mathrm{cf}^{\mathrm{CO}} \mathrm{Col} \mathrm{I}^{4}$, or perhaps had received an affectionate letter from him.

5. vitró $\mu v \eta \sigma \iota v]$ properly of an external reminder, cf. $2 \mathrm{P}_{\mathrm{I}^{13}} 3^{\mathbf{1}}$

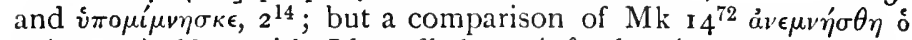
П'́́ makes it doubtful whether the difference can be pressed in

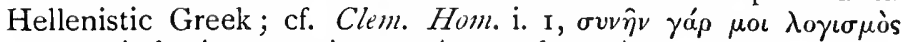

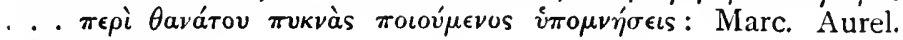
vii. $27, \mathrm{x} .34$. 


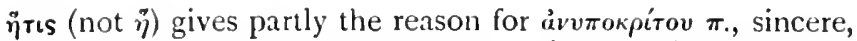
for it was inherited as well as personal. Timothy, like the writer $\left({ }^{3}\right)$, has a family religion behind him; cf. the appeal of Virtue to

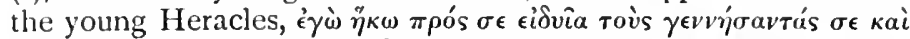

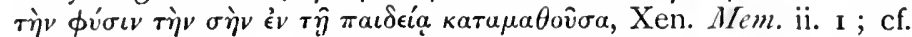
I $2^{8-15}$ note, p. $3 \mathrm{I}$. This does not necessarily imply that Lois and Eunice had become Christians, though it is probable. The language might have been used by St. Paul of religious Jewesses who had trained the young l'imothy in the Jewish expectations of a Messiah, cf. $3^{15}$.

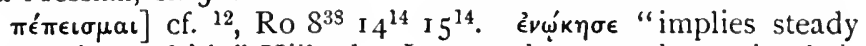
and persistent faith," Hillard. It was always at home in their hearts ; cf. ${ }^{24}$.

6-ii. 13. Appeal to Timothy for greater effort, for courage to face danger and difficulty, and for loyalty to the Apostle's doctrine. The appeal is based upon the reality of God's power to strengthen him $\left({ }^{7-10}\right)$, the example of the Apostle $\left({ }^{11.12} 2^{9.10}\right.$ ), and of Onesiphorus $\left({ }^{15-18}\right)$, the memory of the Ricen Christ $\left(2^{8}\right)$, and the sense that the doctrine is a sacred trust $\left(\begin{array}{ll}13.14 & 2^{1.2}\end{array}\right)$. The

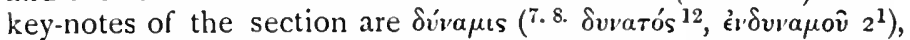

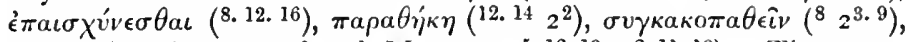
$\pi i \sigma \tau \iota s$ (loyalty to a loyal Master, $\mathrm{I}^{5.12 .13} 2^{2.11 .13}$ ). There are many points of kinship in phrase and thought with the earlier letters, cf. Ro $\mathrm{I}^{16} 8^{15}$, I Co $15^{55}$, Eph $2^{5-9}$, but none suggest conscious adaptation. The writer is perhaps feeling his way towards the request that Timothy will come to him at once to Rome. For that he will need courage, and he must leave faithful men in charge of his work at Ephesus.

6-14. Paraphrase. Feeling this confidence, I write to remind you to stir into full life that gift of God which is within you, which was given by the laying of my hands upon your head. For the gift which God gave us was no spirit of cowardice, but a spirit of strength combined with a spirit of love for others and of selfdiscipline. So then, as you have that spirit, do not be ashamed of the witness which we have to bear about Our Lord, do not be ashamed of me because the preaching of Him has led me to imprisonment; nay, be ready to share my sufferings in the cause of the Gospel: you have not to rely on your own strength, but on the strength of God Himself-of the very God who saved us and called us into His kingdom by a holy call to holiness, and that not in virtue of our own efforts, but in virtue of a purpose cntirely His own, of a gift freely given-given indeed to us as embodied in Christ Jesus before time began, though only shown in these latter days by the bright light which radiated from the appearance of our Saviour Christ Jesus on earth, when He 
destroyed the power of the dread tyrant death and brought to clear view the full meaning of life, aye of immortal life, through the good tidings which I was appointed to proclaim, to carry with authority throughout the world and to teach its truths. It is because I have done this that I am a prisoner now, that I endure these fetters; but I am not ashamed of them, for I know Him whom I have trusted, and I feel confident that $\mathrm{He}$ has strength to guard safely all that I have entrusted to His keeping till that great day to which we Christians look forward. Take then as your pattern of sound doctrine the pattern of the doctrine which I taught you, hold it firmly in a spirit of faith and of that true love which is only found in union with Christ Jesus. It is a trust put into our hands for safe keeping; it is the most precious of all trusts; guard it then with the help of the Holy Spirit who dwells in our hearts.

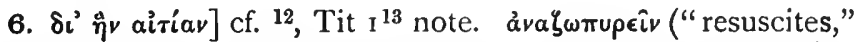
Vulg. ; "recrees," Ambros.), properly "to stir up smouldering embers into a living flame," "to keep at white heat" (Parry) ("O joy that in our embers Is something that doth live"); there may be a conscious reference to the thought of the Spirit as fire, cf. Acts $2^{3}$, Mt $25^{8}$, I Th $5^{19}$; cf. Seneca, Ep. 94, "Honestarum rerum semina animi nostri gerunt quæ admonitione excitantur : non aliter quam scintilla flatu levi adjuta ignem suum explicat" (Wetstein); but the use in the $\operatorname{LXX}\left(2 \mathrm{~K}^{1.5}\right.$ to bring to life a dead child, Gen $45^{27}$, I Mac $13^{7}$ "to revive" (intrans.)), makes it very doubtful whether the metaphor was consciously present in Hellenistic Greek; cf. Ign. ad Eph. c. I, $\dot{\alpha}^{\prime}{ }^{\prime} a \zeta \omega \pi v \rho \eta \dot{\eta} \sigma \alpha \nu \tau \epsilon \mathrm{s} \dot{\epsilon} \nu$

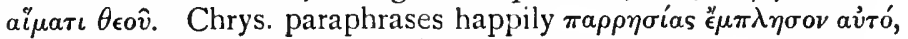

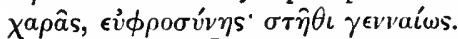

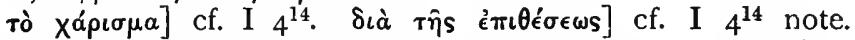
The time referred to is probably the same as there, the ordination for his present work at Ephesus: the context there suggesting a reference to the presbyters, the personal appeal here suggresting a reference to his own act alone. But the allusion here to Timothy's home training $\left({ }^{5}\right)$, and the character of the gift conferred $\left({ }^{7}\right)$, leave it possible that the reference is to Paul's first choice of Timothy to be his minister (Acts $16^{2}$; so Hort, Christian Ecclesia, p. 184), or even to his confirmation at the time of his conversion, Acts $14^{7}$ (so Bp. Chase, Confirmation in the Apostolic Age, pp. 35-40). On the other hand, the whole context of the epistle implies an appeal to one in an ordained and authoritative position.

7. iं $\mu \hat{\imath} v]$ " to you and me," "to us his ministers"; the statement is true of all Christians, cf. I. $2^{15}$, but in a special degree of ministers, and the context $\left({ }^{\prime} \delta \omega \kappa \epsilon \nu\right.$ taking up rò $\chi \alpha \alpha^{\alpha} \iota \sigma \mu \alpha$, and 


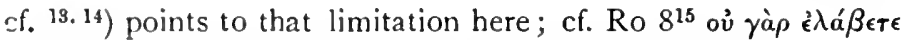

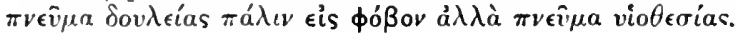

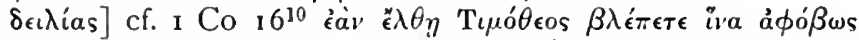

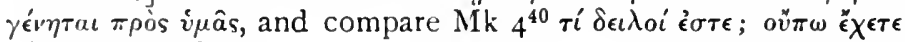

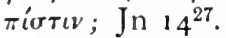

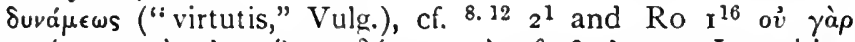

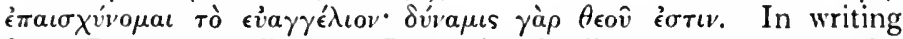
from Rome as well as to Rome he dwells upon power as the essential characteristic of the Gospel, a power which is to prove stronger than the Empire of power; cf. also I Co $4^{19.20}$.

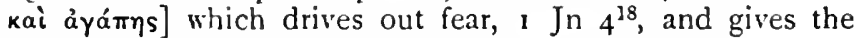
impulse to go to the aid of others in their hour of need.

$\sigma \omega \phi \rho o v i \sigma \mu o v$ (here only in N.T.), the power to make $\sigma \omega \phi \rho \omega \nu$; whether to discipline others (cf. Tit $2^{4-6}$ ), or to discipline oneself, to keep oneself in hand, free from all excitement or hesitation; it is "the sanity of saintliness," cf. Bp. Paget, Studies in the Christian Character, pp. 64-67. The context probably limits the reference here to self-discipline ("sobrictatis," Vulg.: "sance

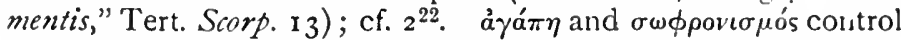
the exercise of divauss. The Christian minister must be strong, efficient, courageous, but never forget personal tenderness for

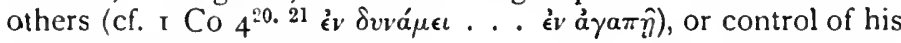
own temper.

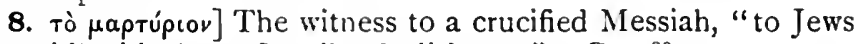
a stumblingblock, to Gentiles foolishness," I Co ${ }^{23}$.

Toû kupiou $\dot{\eta} \mu \hat{\omega} \nu]$ perhaps with conscious contrast to the Emperor, "hunc opponit Cæsari quem sui sic appellabant" (Bengel); cf. Tit $2^{13}$ note.

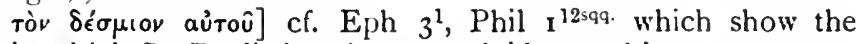
strain which St. Paul's imprisonment laid upon his converts.

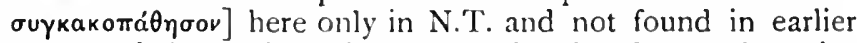
writers: probably coined by St. Paul, who frequently coins compounds of $\sigma v^{\prime}$ out of his deep sense of the close "with. ness" of Christians with each other and with Christ. The main thought here is "suffer with me on behalf of the Gospel"; cf. $2^{3.9} 3^{10}$ ("collabora in Exangelio," Ambros.), rather than "suffer with the Gospel" ("collabora Evangelio," Vulg.), which

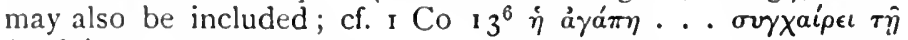

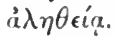

9. Every word emphasizes the power which has been given to Christians ${ }^{7}$ : a power which has done what man could not do of hinıself, which has acted out of love for man, which has destroyed his chief eneny and given him life, which therefore calls for some return and gives strength to face suffering and death; cf. Tit $1^{3} 3^{5}$, Ro $8^{28-30} 9^{11}{ }_{1} 6^{25.26}$, Eph $2^{7-9}$ (some of which may have Leen in the writer's mind), and Ep.Barn. c. 5, $\S$, 
which may be based on this passage, a viròs $\delta \grave{~ i v a ~ \kappa a \tau a \rho \gamma \eta ́ \sigma \eta ~ \tau o ̀ v ~}$

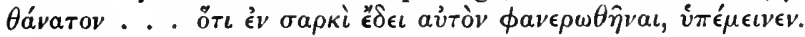

$\kappa \lambda \eta \dot{\sigma \epsilon \iota}$ áyía] mainly "with a calling to be holy," cf. $\kappa \lambda \eta \tau$ is

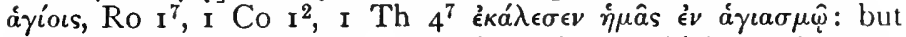
with the further thought of God's holiness which we have to imitate, cf. I P 15.16: "quæ tota ex Deo est et nos totos Deo vindicat" (Bengel).

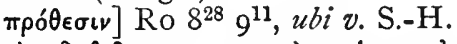

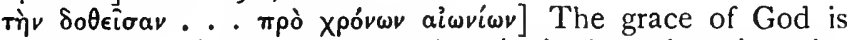
embodied in Christ Jesus: we only gain it through union with $\mathrm{Him}$, and it was given to Him by God long before we were born. The reference may be either to the gift to mankind contained in the promise of the victory of the seed of the woman, Gen $3^{15}$ : this would be supported by the allusion to Gen in $I 2^{14}$ and by the use of $\pi \rho \dot{o} \chi \rho . a i \omega \nu$. in 'Tit $\mathrm{I}^{2}$; or to the gift to mankind contained in the pre-existent Christ before the world was created, as even then $\mathrm{He}$ was the recipient of the Divine life of Sonship of which man was to partake: it was given to us in our ideal. Cf.

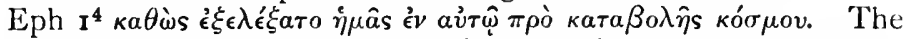
other reminiscences of the Ephesian letter in the verse makes this the more probable view. Pelagius draws a human analogy, "Nam homines solent filiis parare prædia priusquam nascantur."

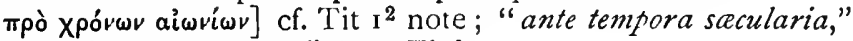
Vulg. Ambros. ; "aterna," Aug. Thd.

10. Ėrıqueías ("illuminationem," Vulg.) here only of the Incarnation; but cf. Tit $2^{11}$ note, $3^{4}$ e $\pi \epsilon \phi a ́ v \eta$. Here the two thoughts of the divine intervention of a saviour in the hour of

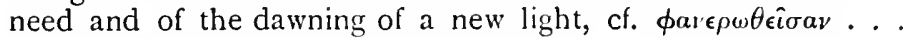

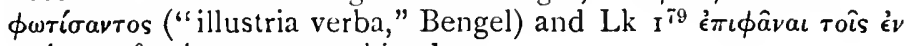

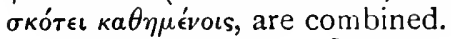

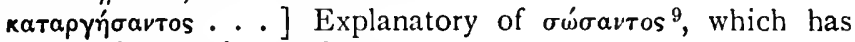
just been taken up by $\sigma \omega \tau \hat{\eta} p o s$.

ròv $\theta$ ávarov] That tyrant death (cf. '̇ $\beta a \sigma i ́ \lambda \epsilon v \sigma \epsilon \nu$, Ro $5^{14}$ ) whose presence caused constant fear and took the sense of freedom out

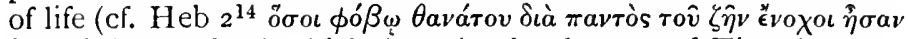
$\delta o v \lambda \epsilon^{\prime}(a)$ ), that death which the writer has learnt and Timothy must learn to face.

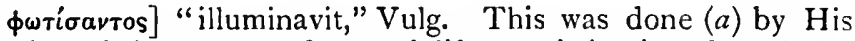
teaching of the nature of eternal life, consisting in a knowledge of God and beginning here on earth; it is interesting to compare the language of Epictetus (I. iv. 3I) about Chrysippus: $\tau \hat{\omega} \tau \dot{\eta} \nu$

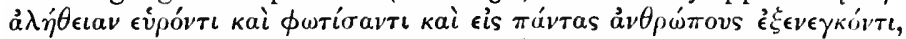

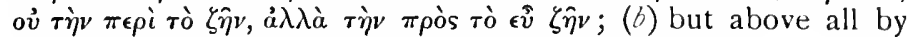
the fact of the Resurrection, cf. $2^{8}$, I Co $15^{51-56}$, Acts $2^{27}$. There was hope of immortality in the world before, but the Resurrection had converted it into a certainty and shown from beyond the 
grave the continuity of life there with life here; cf. Driver, Sermons on the O.T., Sermon 4; Mozley, Essays, ii. pp. I70-75. "The Gospel first gave to a future world clearness and distinctness, shape and outline; the Cospel first made it a positive district and region on which the spiritual eye reposes, and which stretches out on the other side the grave with the same solidity and extension with which the present world does on this side of it. $A$ future life was not an image before the Gospel: the Gospel made it an image. It brought it out of its implicit form, and from its lower residence within the bosom of the great fundamental doctrine of true religion, into a separate and conspicuous position as a truth. This was a bringing to light, and a species of birth, compared with which the previous state of the doctrine was a hidden and an embryo state."

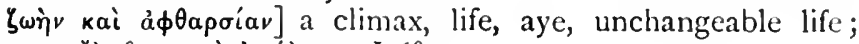

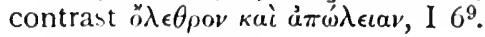

11. Cf. I $\mathrm{Ti}^{7}$.

12. $a \lambda \lambda \lambda^{\prime}$ oủk $\left.\epsilon^{\prime} \pi a t \sigma X.\right]$ cf. ${ }^{8}$ and Ro $x^{16}$.

i $\pi \in \pi i \sigma \tau \epsilon u k a]$ not "whom I have believed," as in Tit $3^{8}$ oi $\pi \epsilon \pi i \sigma \tau \epsilon \cup \kappa o ́ \tau \epsilon s \quad \theta \epsilon \hat{\omega}$, but rather "whom I have trusted," "to whom I have entrusted my deposit"; cf. 2 Mac $3^{22} \tau \dot{a} \pi \epsilon \pi \iota \sigma \tau \epsilon \nu \mu \epsilon^{\prime} \mathbf{a}$

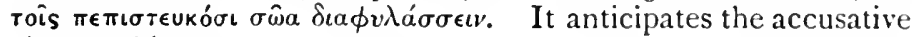
$\tau \dot{\eta} \nu \pi \alpha \rho a \theta \dot{\eta} \kappa \eta \nu$.

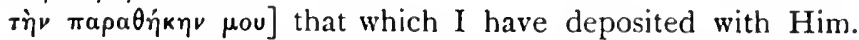
(v. Additional Note, p. 90): all my precious things which $I$ have put under His care. He does not define or limit; it will include his teaching ( $\mathrm{I}$ Co $3^{12-15}$ ), his apostolic work, his converts

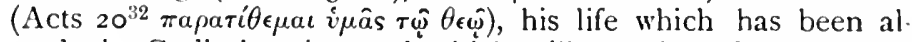
ready in God's keeping and which will remain safe there even through death (cf. Lk $23^{46}$, I $\mathrm{P} 4^{19}$ ). The last is perhaps the

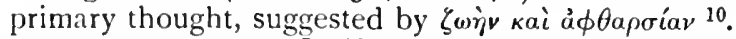

ék

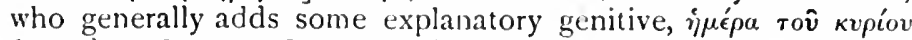
$\dot{\eta} \mu \hat{\omega} v$, 'I $\eta \sigma o \hat{v} \mathrm{X} \rho(\sigma \tau o \hat{v}, \dot{a} \pi \circ \lambda v \tau \rho \dot{\omega} \sigma \epsilon \omega)$. The day is now so present to his mind that it needs no defining.

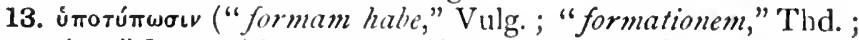
"exemplum," Jerome) here and I I ${ }^{16}$ (where see note) only in N.T.;

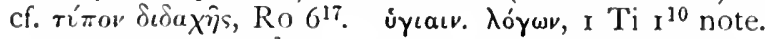

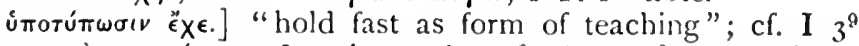

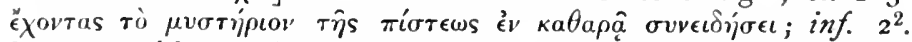
Parry would translate "hold forth in your life: let your own character represent to the world wholesome teaching." This is

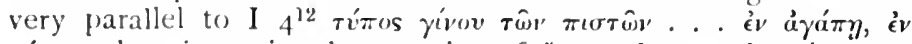
$\pi i \sigma \tau \epsilon \iota:$ but it strains the meaning of $\epsilon^{\prime} \chi^{\epsilon}$ and scarcely arises out of the context.

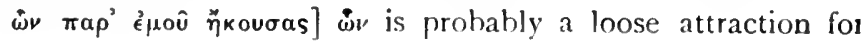


oṽs or possibly $a$ (cf. $\left.2^{2}\right)$, "hold as outline of sound teachings those teachings which you heard from me." Hort regards $\stackrel{\star \omega}{\nu}$ as a primitive corruption of $\% \nu$ after $\lambda o^{\prime} \gamma \omega v$, "hold as pattern of sound doctrines that doctrine which you heard from me." W.-H. ii. p. 135 .

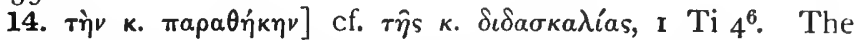
thought of his own deposit with God ${ }^{12}$ suggests that deposit which Christ has left with him, a far more precious and ideal

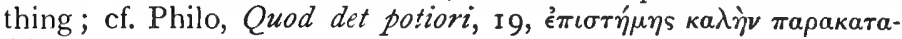
$\theta \dot{\eta} \kappa \eta \nu$.

Sıà $\Pi v$. 'A yíou] cf. Ro 811. This is true of all Christians, but the thought here is, probably, still that of the special gift to ministers for their work 6.7 .

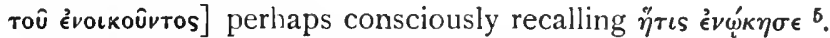

15-18. Examples of warning and encouragement.

Paraphrase. I appeal to yourself : you know instances both of cowardice and of courage: you know that all those in Asia turned away from me, of whom Phygelus and Hermogenes are the chief. On the other hand, may the Lord be merciful to the family of Onesiphorus, for many a time did he refresh me, every visit of his like a breath of fresh air; and he was not ashamed of my fetters, nay, when in Rome on a visit he took great pains to enquire where I was imprisoned and he found me: the Lord grant to him that he may find mercy from the Lord in the last great day. Yes, and all the many services which he rendered in Ephesus you have yourself the best means of knowing.

For similar warning, of. I $\mathrm{I}^{19.20}$, at the same point in the letter; but here the stress is on the encouragement of Onesiphorus which is described at much fuller length, and accompanied with prayer for him.

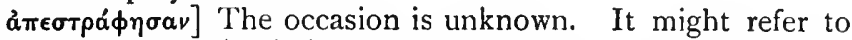
doctrinal apostasy (cf. ${ }^{13.14}$ ), but more probably to some failure to help Paul himself $\left(\mu \epsilon\right.$, cf. Mt $\left.5^{42}\right)$ : as it is introduced mainly as a foil to the personal kindness of Onesiphorus, cf. $4^{10} \Delta \eta \mu \hat{a} s$ $\mu \epsilon \dot{\epsilon} \gamma \kappa a \tau \epsilon^{\prime} \lambda \iota \pi \epsilon \nu$. Possibly all the Asiatic Christians who were in Rome at the time, cf. $4^{16}$, failed to support him at his trial and

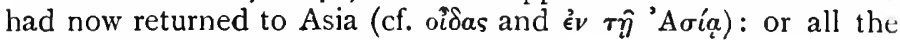
Christians in Asia at the time when he was arrested there failed to help him or come with him to Rome.

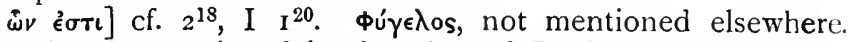
'Eppoyévns is mentioned in the Acts of Paul and Thecla (c. I)

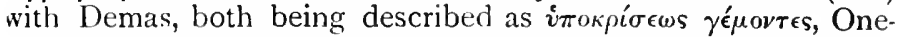
siphorus (c. 2), as welcoming Paul to his house at Iconium.

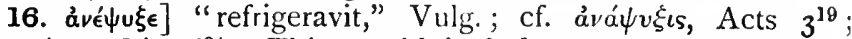

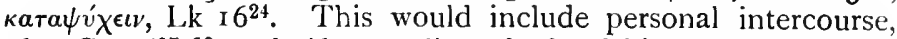
cf. I Co $16^{17.18}$, and gifts to relieve the hardships of his imprison- 
ment, cf. Phil $4^{14-17}$; but, though it includes his visit at Rome, it need not be confined to that time. Cf. Ign. Eph. c. 2, Kро́коs

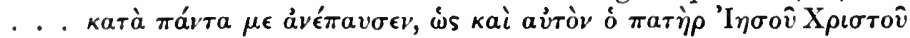
$\dot{a} \nu a \psi v \dot{\xi} a \iota$.

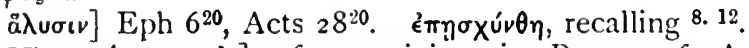

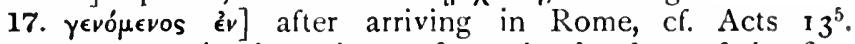
$\dot{\epsilon} \zeta \eta \dot{\eta} \eta \sigma \epsilon$ seems to imply a change from the freedom of the first imprisonment, Acts $28^{30}$.

18. $\delta \omega \dot{\eta}]$ A late form of the optative, cf. 2 Th $3^{16} ; \mathrm{W} . \mathrm{H}$. ii. p. $168 .{ }^{2} \delta$ xúpios, the Lord Christ; cf. 2.8.16. Tapà kupíou, possibly also "from Christ" as the Judge. cf. $4{ }^{8}$; or "from the Father," a stereotyped phrase for mercy at the day of

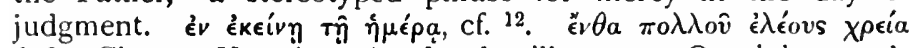
$\dot{\eta} \mu \hat{i v}$, Chrys. Yes, but the Lord will say to Onesiphorus, $\dot{\epsilon} v$

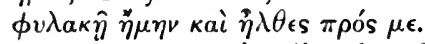

The context implies that Onesiphorus was separated from his family, probably that he was dead; cf. $\tau \hat{\omega}$. . . ök $\omega\left({ }^{16}\right.$ and $\left.4^{19}\right)$,

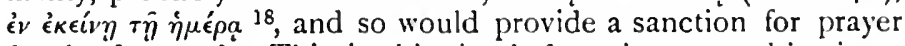
for the departed. This, in this simple form, is a natural instinct ;

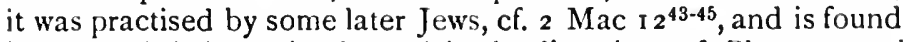
in early Christian epitaphs and in the liturgies; cf. Plummer, $a d$ loc.; Gayford, The Future State, c. 4. IVohlenberg quotes the Acts of Paul and Thecla, $\S 28$, which is a prayer that a heathen may be transferred after death to the abode of the righteous.

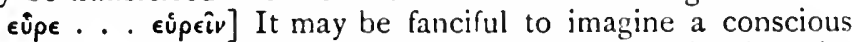
play on the words "invenit me in tanta frequentia: inveniat misericordiam in illa panegyri " (Bengel); but Paul was fond of such playful allusions and we can imagine him thinking of the meaning of Onesiphorus, "the help-bringer" ; cf. Philem ".

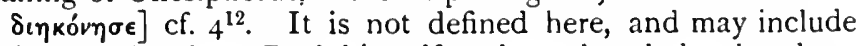
services rendered to Paul himself and to the whole church at Ephesus.

$\beta \boldsymbol{C}^{\prime} \lambda$ Tıv] Perhaps "better than I," but the comparative sense cannot be pressed; cf. Moulton, Gr. N.T., p]). 78 and $23^{\prime \prime}$;

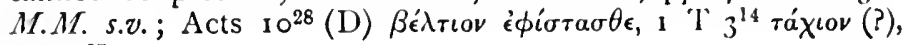
Jn $13^{27}$.

\section{Additional Note to Chapter I.}

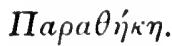

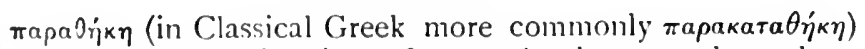
always implies the situation of one who has to take a long journey and who deposits his money and other valuables with a friend, trusting him to restore it on his return; cf. Tob $I^{14}$

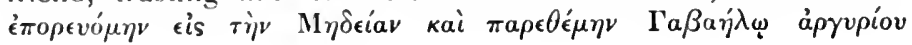




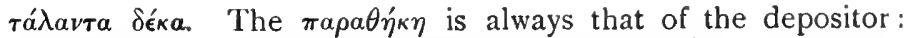
the duty of the friend is $\phi v \lambda \alpha \sigma^{\prime} \sigma \epsilon \iota$ and $\alpha \pi n o \delta \iota \delta o v a \iota$. From the earliest days this duty was protected by law; cf. Hammurabi, $\S \S 122-126$. "If a man shall give silver, gold, or anything whatsoever, all whatever he shall give he shall show to witnesses and fix bonds and give on deposit"; and exact regulations were laid down fixing the penalty in the case of loss or damage; cf. Ex $\mathbf{2 2}^{\mathbf{7 - 1 3}}$, Lev $6^{2 \cdot 7}$. The striking story of Glaucus, who was condemned by the Pythian oracle for even wishing to retain such a deposit, shows the importance attached to faithfulness in this duty (Herod. vi. 86; Juv. xiii. 199-208), and it was one of the first duties impressed on Christians, who bound themselves on each Sunday "ne fidem fallerent, ne depositum appellati abnegarent," Pliny, Ep. 96. Among the Jews in Maccabean times the place of the friend was taken by the Temple treasuries, which took charge of such deposits and of the money of those who had no natural guardians; cf. 2 Mac $3^{10-40} \pi \alpha \rho \alpha \kappa \alpha \alpha \theta \eta^{\prime} \kappa \alpha$

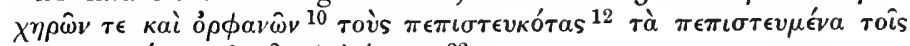

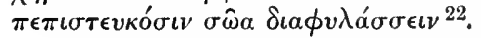

In the N.T. the substantive is only used in the Pastoral Epistles: it comes naturally from one who is preparing for his last long journey, but the verb occurs elsewhere, and the word was used metaphorically in many applications. (a) Of the body of truth which Christ deposits with the Apostle and the Apostle with Timothy, cf. I $\mathrm{T}^{18} \pi \alpha \rho \alpha \tau^{\prime} \theta \epsilon \mu \alpha \iota, 6^{20} \tau \dot{\eta} \nu \pi \alpha \rho \alpha \theta \eta^{\prime} \kappa \eta \nu, 2$ T I $^{14}$, and which Timothy has to hand on to others when he takes his journey to Rome, 2 T $2^{2} \pi \alpha \rho a ́ \theta 0 v$. This use may have been suggested by the parable of the Pounds, Lk $19^{12}$. (b) Of our true self which the Creator has handed over to us to keep safe,

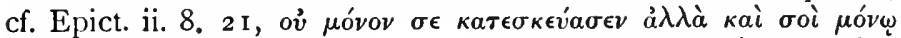

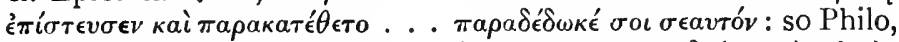

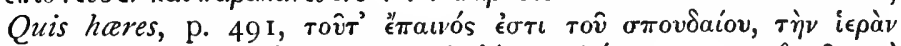

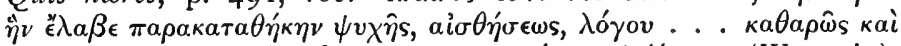

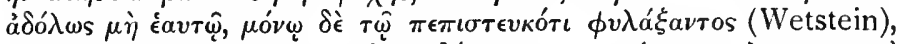

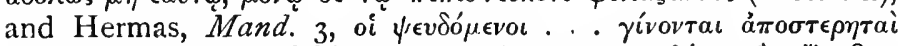

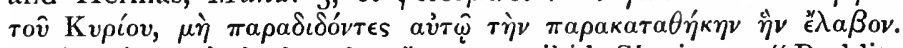

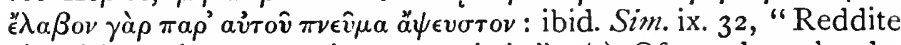
ei spiritum integrum sicut accepistis." (c) Of good works deposited with God in heaven: a very common Jewish thought, 4 Esdr $8^{33}$ "justi quibus sunt opera multa reposita apud te"; Apoc. Bar I $4^{13}$ "justi sine timore ab hoc domicilio proficiscuntur quia habent apud te vim operum custoditam in thesauris"

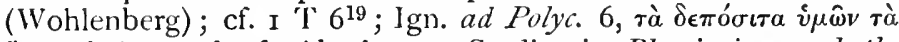
" $\rho \gamma \alpha \dot{v} \mu \hat{\omega} v$, and cf. Abrahams, Studies in Pharisaism and the Gospels, p. 148. (d) Of persons entrusted to the care of others,

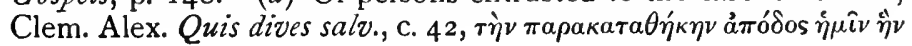




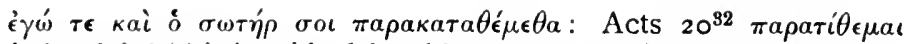
$\dot{v} \mu \hat{a} s \tau \hat{\omega} \theta \epsilon \hat{\omega}$ (this is said of the elders at Ephesus) ; Chrys. p. $597 \mathrm{C}$,

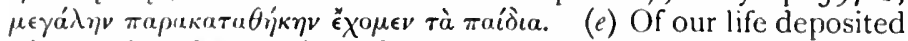

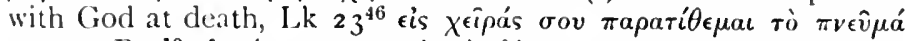

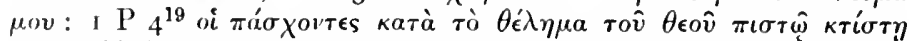

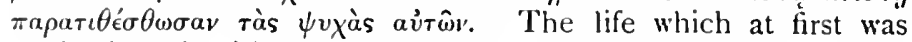
God's deposit with us becomes our deposit with God.

\section{1-13. Further appeal to Timothy to take heart and to entrust} his teaching to others.

Paraphrase. So then, as others have failed me, I turn to you to whom I have a right to appeal, such as I had not to Onesiphorus, as you are my own child in the faith-and I bid you to realize constantly the strength which is yours in virtue of the grace given you through your union with Christ Jesus. In that strength, Come to me and, before you comc, hand over the truths which you heard from me, in the presence of many witnesses, to men on whom you can rely as being of ability enough to train others in their turn. Then come and take your share of stffering as a true soldier in the army of Christ Jesus: now every soldier hopes to please his general and, therefore, while on active service does not tie himself up with business affairs: so, too, an athlete hopes to win the prize, but he cannot win it unless he observes to the end the rules of the contest: in the same way a husbandman hopes to take his share first of the fruits of the ground, but he must work hard for it. Think over the way in which this applies to you: for the Lord is ready to give you discernment in all things.

Keep ever in your memory Jesus Christ-as one who has been raised from the dead, and as the offspring of a Royal ancestor, as a living Lord, for this is the central truth of the Cospel entrusted to me. In the service of that Gospel, I am now suffering, aye, imprisoned and fettered as though $I$ was a criminal : yet God's word has never been fettered by man: it has heen free and doing its work all the time: and, therefore, I am ready to endure this and anything to help God's chosen ones that they with me may obtain salvation, that complete salvation which is given by union with Christ Jesus and which carries with it a glory that is eternal. How true is that great saying :

"Who shares Christ's death His life shall share:

They reign with llim their cross who hear:

Who llim deny lle will deny:

Though our failh fall, Ile cannot lie."

Nay, He cannot be untrue to Himself. 
1. $\sigma u$, in contrast to $\mathrm{x}^{15-18}$ : oûv, taking up $\mathrm{I}^{14}$, "as I need some one to guard the deposit"; cf. I ${ }^{14} \pi \alpha \rho a \theta j k \eta v$ with $2^{2}$

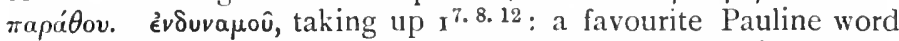
(six times: elsewhere in N.T. only Acts $9^{22}$ where it is used of

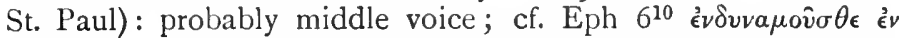

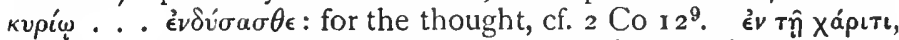
"grace" in its widest sense, but perhaps with special reference to the $\chi$ áp $\iota r \mu a$ of $1^{6}$.

2. The connexion of 1 and 2 is not clear: there may have been practical difficulties to be faced in the choice of these men so that Timothy would need to fall back on God's strength : or 1 may refer mainly to the courage needed for coming to Rome; 2 to the necessity of appointing other ministers to take his place while absent and in case he should never return.

ทंkouoas] possibly at the time of $\mathbf{1}^{6}$, or during the whole ministry ; cf. $3^{10}$.

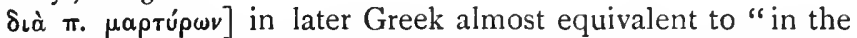

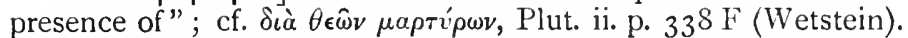
Field (Ot. Norv. ad loc.) suggests that it was a legal term: if so, it would carry a slightly stronger meaning, "supported by many witnesses." Here they may be the presbyters of $\mathrm{I} \mathrm{Ti}_{4}{ }^{14}$, or the hearers of St. Paul's teaching from time to time who bore witness to its truth (cf. $2 \mathrm{Co}_{1}{ }^{20} \tau \dot{\alpha} \alpha \mu \dot{\eta} v, \mathrm{Jn} 3^{33}$ ) and also knew what Timothy had heard; cf. I Ti $6^{12}$. But may it not be constructed with $\pi a \rho a \dot{\theta} \theta$ ov of the further security which Timothy is to take? in which case the witnesses will be presbyters, as in $\mathrm{I} \mathrm{Ti}_{4}{ }^{\mathbf{1 4}}$.

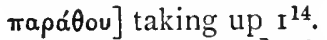

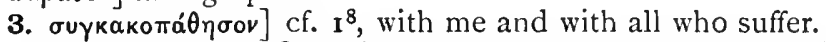

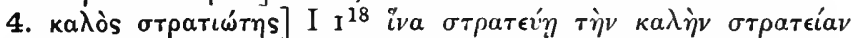
and $\sigma v \sigma \tau \rho \alpha \tau \iota \dot{\tau} \eta \varsigma$, Philem ${ }^{2}$, Phil ${ }^{25}$, show that St. Paul applied it specially to the ministers of Christ. The three similes are found together in I Co $9^{6.7 .24-27}$, and there may be a conscious reminiscence of that chapter, though the main thought is different here. Here stress is laid on two points : $(a)$ the conditions of true service: it needs whole-hearted devotion $\left({ }^{4}\right)$, loyalty to the rules $\left({ }^{5}\right)$, hard work $\left({ }^{6}\right) ;(b)$ the natural hope of a reward, the reward of pleasing the Master, of winning a crown, of partaking of the results. The same thoughts recur in ${ }^{11-13}$. The application is both to Timothy himself and to the regulations he is to make for the $\pi \iota \sigma \tau 0^{\circ} \stackrel{a}{a} \nu \theta \rho \omega \pi \circ \iota$.

$\left.\dot{\epsilon} \mu \pi \lambda \epsilon^{\prime} \kappa \epsilon \tau a l\right]$ cf. $2 \mathrm{P}_{2}^{20}$. Epict. iii. 22. 69, of the ideal Cynic,

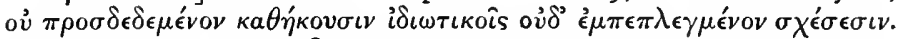

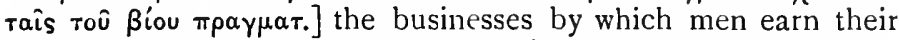

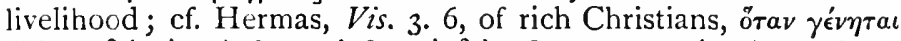

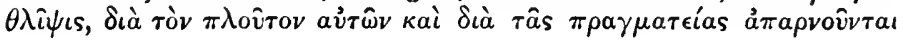




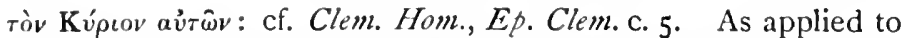
ministers this command requires whole-hearted devotion to their work, perha|s implying abstinence from secular trades (cf. I Co $\left.1^{8.7}\right)$ : but this was not required at first. The Council of

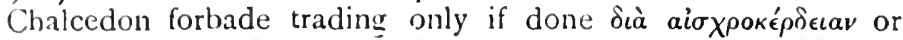

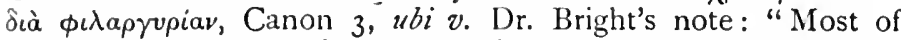
the clergy of Cæsarea in Cappadocia practised sedentary trades for a livelihood" (Basil, Ep. 198), "and some African canons allow, or even direct, a cleric to live by a trade, provided that his clerical duties are not neglected" (Mansi, iii. 955). . . . "In the Anglo-Saxon Church ... the canons of King Edgar's reign ordered every priest diligently to learn a handicraft (No. I I. IVilkins, i. 225)." Cf. also Hatch, Bampton L. vi.; Dict. Chr. Ant., s.v. Commerce.

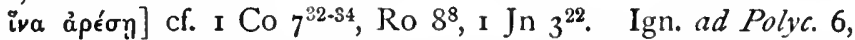

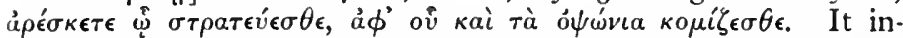
cludes the thought of "pleasing by good service"; cf. Milligan on I Th $2^{4}$. A useful expansion of these two verses will be found in S. Greg. Reg. Past, ii. 7 .

5. $a \theta \lambda \hat{\eta}]$ cf. I $\mathrm{Ti}_{4}{ }^{\tau-10}$. These two similes are expanded fully in Tertullian, ad Mart. c. 3 .

$\left.\nu \mu^{\prime} \mu \omega s\right]$ will include both the training for the contest and

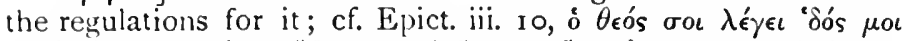

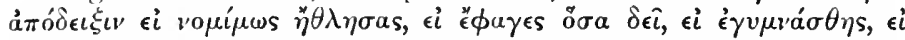

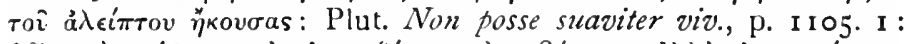

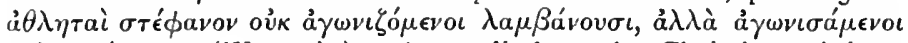

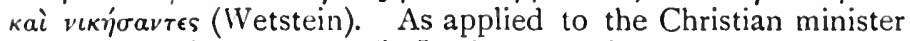
the training is that of $\mathrm{I} \mathrm{Ti}_{4}^{7}$; the regulations those of the law of Christ, especially those laid down here in 10-12.

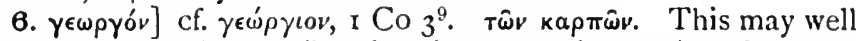
include $(a)$ the "honour" and maintenance he receives from the Church, cf. I $5^{17.18}$; and $\delta \epsilon \hat{\imath}$ seems to point to some regulation that Timothy is to enforce; $(b)$ the spiritual reward which comes here on earth in the sense of God's approval and blessing on the

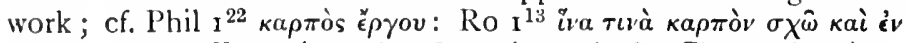

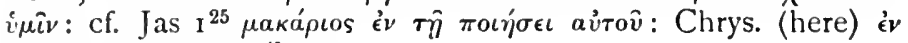

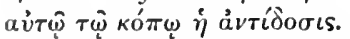

7. $v o \in \in]$ cf. Mk $13^{14}, \mathrm{Eph} .3^{4}$, Rev. $13^{9}$; and for the appeal,

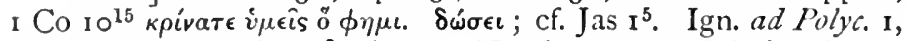

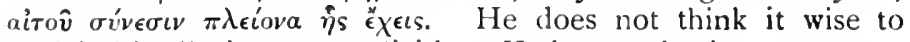
explain his allusion too explicitly. Verbum sapienti.

8. $\mu \nu \eta \mu o ́ v \epsilon u \epsilon]$ so St. Peter is said to have appealed to his wife

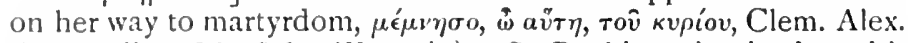
Strom. vii. p. 869, $\$ 6_{3}$ (Wetstein). St. Paul is acting in the spirit

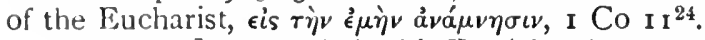

'I qooûv $\mathrm{X} \rho$.] here only in this E.p. (elsewhere X $\rho$. 'I 
stress on the historic life as the first thought, and $\mathrm{X} \rho$ or óv perhaps consciously a predicate. "Jesus-as the Messiah"; cf. Ro I ${ }^{3.4}$.

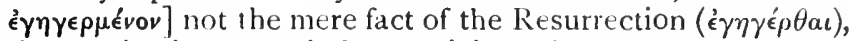
but keep Him in your mind as a Living Risen Lord who is able to give His life to you ; $\mathrm{cf} \sigma \nu \zeta^{\prime} \dot{y}^{\circ} \sigma \mu \epsilon \nu^{11}$.

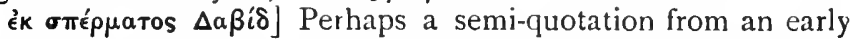
form of a creed : cf. Ign. Eph. 18, Trall. 9, Smyrn. 1, in all which places it emphasizes the reality of the human nature. There may be some such antidocetic thought here (cf. I $2^{5}$ note), and in $\epsilon^{\epsilon} \gamma \eta \gamma \epsilon \rho \mu \dot{\epsilon} \nu v$ a refutation of Hymenæus and Philetus (18); but the context lays stress rather on the power of Christ to help, so that $\dot{\epsilon} \kappa \sigma \pi . \Delta$. expands the thought of X true descendant of David, a King who can share his Kingdom; cf. $\sigma v \mu \beta a \sigma \iota \lambda \epsilon \dot{v} \sigma o \mu \epsilon v, v{ }^{12}$ and $\operatorname{Lk}_{1}{ }^{32.33}$.

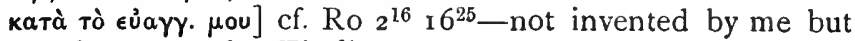
entrusted to me; cf. I Ti $\mathbf{I}^{11}$.

9. ws kakoûpyos] "like a criminal," "quasi male operans," Vulg. ; "ut latro," Ambros.; "ut malefactor," Thdt. : or perhaps "on the charge of being a criminal"; cf. I P $4{ }^{15} \mu \eta^{\prime} \tau \iota s \quad \dot{v} \mu \hat{\omega} \nu$

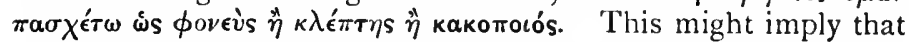
the writer was not tried for Christianity but for some alleged crime; cf. Suetonius, Nero, 16, "afflicti suppliciis Christiani, genus hominum superstitionis novæ ac maleficæ." Tac. Ann. xv. 44, "per flagitia invisos"; but some more definite word than

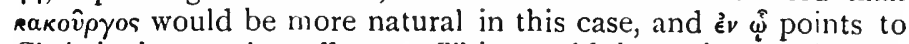
Christianity as the offence. 'This would be quite possible in Nero's time ; cf. Hort on $\mathbf{I}^{\mathrm{P}} \mathbf{2}^{12}$; Chase in Hastings' D.B. iii. p. 784 .

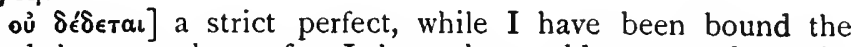
Word has not been, for I have been able to speak on its behalf, cf. $4^{17}$; and others are doing its work, $4^{9-12}$; "God buries His workers but continues His work," cf. Phil I 12-18, Eph $5^{13}$. For the personification, of. I Th $2^{13}, 2$ Th $3^{1}$. Origen,

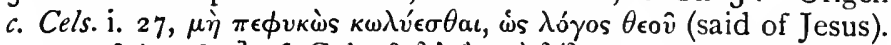

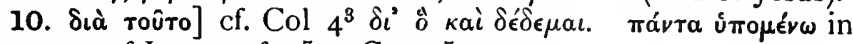
the power of Love; $\mathrm{cf} \mathrm{I}^{7}$, I Co $13^{7}$.

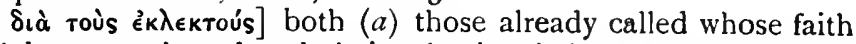
will be strengthened and their salvation helped by the example of my endurance ; $\mathrm{cf} \mathrm{Col} \mathrm{I}^{24}, 2 \mathrm{Co}^{5.6}$; and $(b)$ those objects of God's Love who will be drawn to Christ by it; cf. $4^{17}$. This power of endurance was the fact of St. Paul's life which most

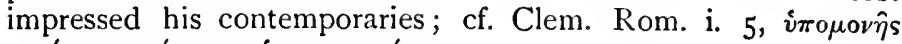

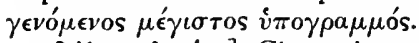

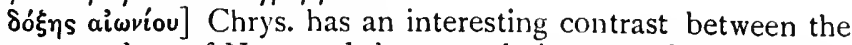
temporary glory of Nero and the eternal glory won by St. Paul.

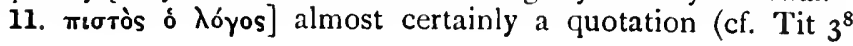


note). It may refer to the preceding verses; if so, most probably to $v .^{8}$, yáp ${ }^{11}$ confirming the writer's appeal to the saying about the Risen and Royal Christ by the quotation of a well-known

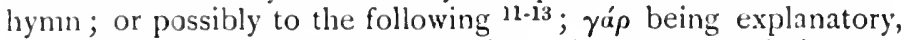
"namely," or a part of the quotation. In any case, $\epsilon \dot{i} \gamma \hat{\alpha} \rho .$. $\pi \iota \sigma \tau o ̀ s ~ \mu \epsilon^{\prime} \epsilon \iota$ is a rhythmical saying, a careful balancing of encouragement and warning. The language is full of reminiscences of earlier passages in the N.T., Ro $6^{8} 8^{17} 3^{3}$, Mt $10^{33}$, and may be a hymn composed in face of persecution, encouraging to boldness and warning against defection. Polycarp, c. 5, has a reminiscence of this place, or perhaps an independent reminis-

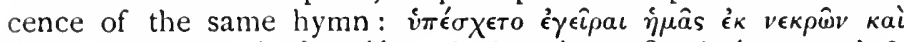

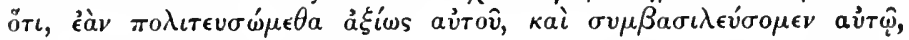
$\epsilon \check{\epsilon} \gamma \epsilon \pi \iota \sigma \tau \epsilon \dot{v} \sigma \mu \epsilon \nu$.

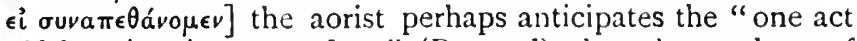
of self-devotion in martyrdom" (Bernard); but the analogy of Ro $6^{8}$ suggests that the primary reference is to baptism : "if our death with Christ was real and complete, so real that we shall be

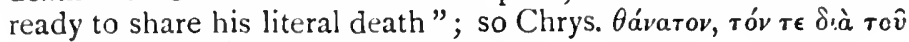

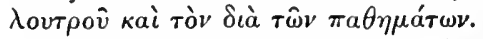

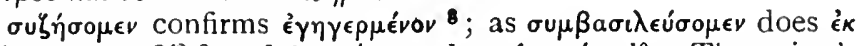

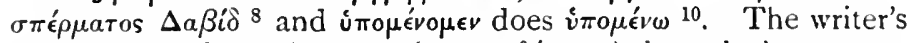
mind passes from the past ( $\sigma v v a \pi \epsilon \theta a$ á $\mu \epsilon v)$ through the present

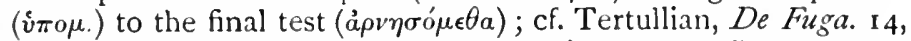
"Non potest qui pati timet ejus esse qui passus est."

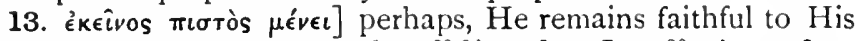
promises of mercy, cf. Ro $3^{3} \mathrm{I}^{29-32}$ and I Jn $3^{20}$, $\dot{a} \pi \iota \sigma \tau o \hat{v} \mu \epsilon \nu$

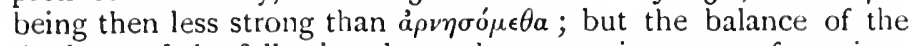
rhythm and the following clause almost require a note of warning: He remains faithful; He keeps his word both for reward and for punishment; cf. $4^{8}$ and ${ }^{14}$, Dt $7^{9}, \mathrm{Ex} 34^{6.7}$.

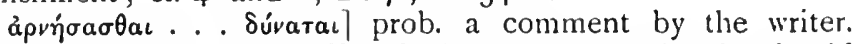
For the thought, cf. Nu $23^{19}$, "God is not a man that he should lie, neither the son of man that he should repent." "Tit $\mathbf{I}^{2} \dot{\delta}$

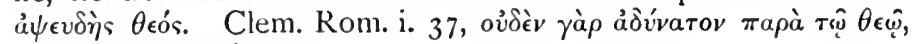

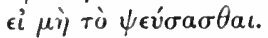

14-26. This paragraph passes from the thought of the subject-

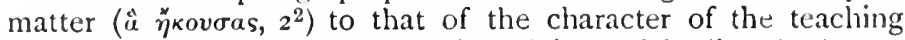
and of the teacher. It begins with advice which Timothy has to give to others, but passes at once to advice to himself. Remind those to whom you hand on your teaching not to strive about mere words $\left({ }^{14}\right)$. Show them in yourself the example of a true worker and teacher, avoiding empty discussions which will tend more and more to lower the tone of religion and eat out the life of the Church (15.17). One case is given of such false teaching $\left({ }^{18}\right)$ : two tests of the true teacher $\left({ }^{19}\right)$ : there is a great variety of char- 
acter within the Church, good and bad, and a teacher must carefully keep from the bad, if he is to be fit for his Master's work $\left({ }^{20 .}{ }^{21}\right)$. For yourself, avoid merely youthful impulses, aim at the central virtues, keeping in touch with all sincere Christians (22). Avoid profitless discussions and all that is inconsistent with the character of the servant of the Lord, who should be patient, skilful in teaching, hopeful for the conversion of opponents $\left({ }^{22-26}\right)$.

The whole paragraph is very analogous to $I 4^{6-16}$; but the notes specially characteristic of this are:

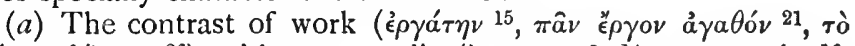

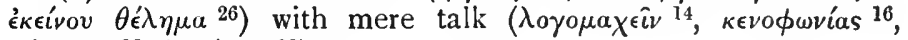

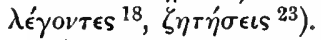

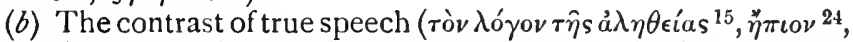

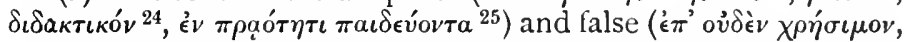

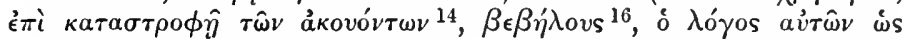

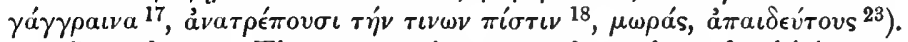

Paraphrase. These are the central truths of which you must remind any to whom you entrust your teaching, and you must charge them as in the sight of their Lord and Master not to be "word-warriors," constantly arguing and wrangling with words as if they wished to ruin rather than to build up their hearers' faith : such wrangling is perfectly useless. With regard to yourself, take all pains to present yourself before God as one who can stand His test-as a real worker, as one who will never be put to shame for bad or scamped work, but as teaching rightly the one message of the truth. But to all these irreligious and frivolous hair-splittings give a wide berth. Those who take part in them will go forward-on a downward grade of impiety: their message will be like a cancer eating into the sound members of Christ's body. To that class belongs Hymenæus and Philetus, for they have entirely missed their aim about the truth, explaining away the literal resurrection and saying that Resurrection is only our past resurrection with Christ in Baptism, and thereby they are upsetting the faith of some. Yet be not alarmed; whatever false teachers may say, the solid foundationstone of God's Temple has been fixed once for all; and on it are two inscriptions carved first by Moses and renewed by Our Lord : one tells of God's knowledge, "The Lord knoweth them that are His own"; the other of man's duty, "Let every one who worships the Lord depart from iniquity." Yet within the Church there will be great varieties: it is like a big house, in which there are not only vessels of gold and silver, but others of wood and earthenware; some for honourable, some for mean uses. If, then, any teacher keep himself quite clear of these false teachers, he will be a vessel for honourable use, set apart for 
service, ready to his Master's hand, prepared to take part in any good work. But that you may be such a vessel, you must turn your back upon all merely youthful impulses and passions; you nıust set your face towards just dealings with others, towards loyalty, love, and peace with all who call the Lord their God out of a pure heart. But these foolish discussions with men of untrained minds persistently avoid: you know they only engender strifes, and, as Isaiah said, "A servant of the Lord must not strive"; nay, he must be courteous to every one, apt and skilful to teach, ready to bear with contradiction, speaking in a gentle tone, as he has to train the minds of opponents. He must always have in his heart the hopeful question, "Mav it not be that God will give them a real change of heart, and they will come to a real knowledge of truth? May it not be that they will come back to their sober senses, saved from the devil's snare? May it not even be that I shall be a fisher of men, and save then alive, and bring them back to do their true Master's Will?"

14. тaûta] = raivta of $2^{2}$, with the addition of the truths in $2^{9-13}$.

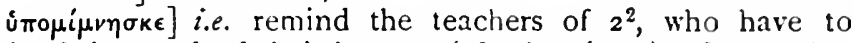

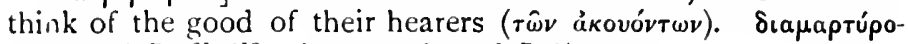

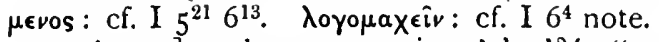

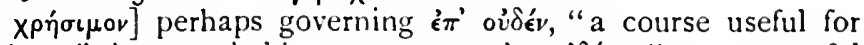
nothing," but probably agreeing with ov $\delta^{\prime}{ }^{\prime}$ ", "to no useful

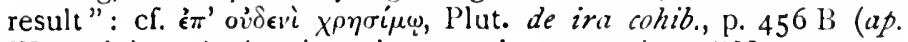
Wetstein). Ambrosiaster's note is suggestive, "Necesse est enim ut contentio extorqueat aliquid, immo multa quæ dicuntur contra conscientiam, ut intus in animo perdat, foris victor abscedat. Nemo enim patitur se vinci, licet sciat vera quæ audit. . . Collatio ergo inter Dei servos esse debet, non altercatio": cf. H. C. G. Moule (ad loc.), "The time of religious controversy is the time above all others to resolve that our souls shall live behind and above zerds, in conscious touch with the eternal Things."

$\varepsilon \pi i]$ denoting the result (Blass, N.T. Gr., $\S 43 \cdot 3$, but without any parallel instance); rather, the result is treated half-ironically as the purpose "as if they set themselves deliberately not to build up, but to throw down"; cf. ${ }^{16}$.

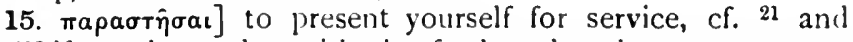
Ro $6^{13-16}$; perhaps also, with the further thought, present yourself for judgment, cf. I Co $8^{3}$, the solemn appeal in ${ }^{14}$ having suggested the thought of God as Judge.

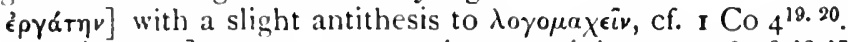

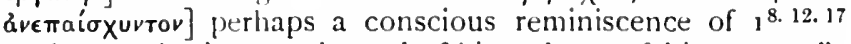
"a workman who is not ashamed of his task or of his master"; but more probably "a workman who will never be put to shame 
by being shown to have done bad work" ("inconfusibilem," Vulg.; "non impudoratum," Ambros.); cf. Phil ${ }^{20} \dot{c}^{2} \nu$ ovj $\delta \epsilon \nu$ ai $\chi^{\prime} v \nu \theta \dot{\eta} \sigma o \mu a l$, and I $\mathrm{Co} 3^{10-15}$. This carries on the thought of $\delta \delta^{\prime}<\mu o v$, and leads up to ${ }^{21}$.

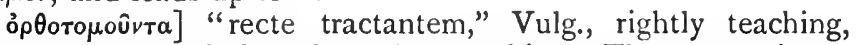
keeping the word free from logomachies. The stress is on opoo- : it is doubtful whether in Hellenistic Greek the metaphor

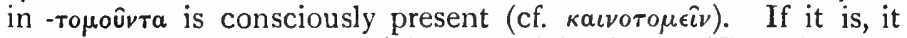
may be that of a plough driving a straight furrow (Chrys.), or of

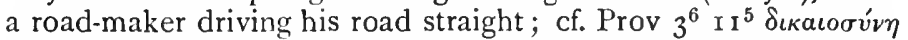

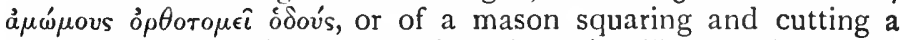
stone to fit it into its proper place (Parry). The whole phrase is used frequently in the Liturgies as describing the duty of the bishop, cf. Introd., p. xxxix ; and o $\rho \theta$ отонía is used of orthodoxy,

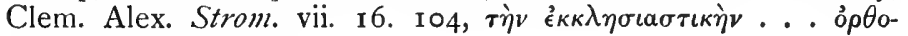

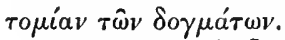

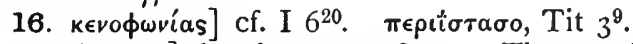

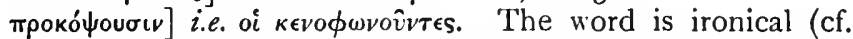
I $4^{15}$ note). They will make progress-on a downward grade,

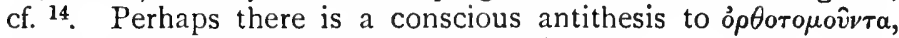

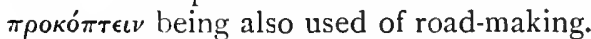

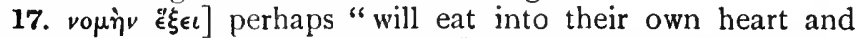
ruin it more and more," $\mathrm{cf}$. Tit $\mathrm{I}^{15}$; but the chief thought is "will spread further into the Church and corrupt others"; cf.

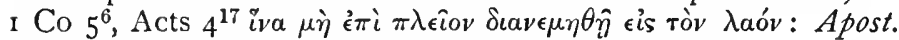

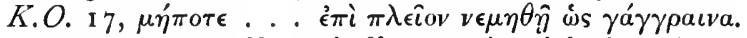

$\dot{\omega} v$ értıv: cf. $\mathrm{I}^{15}$, I Ti ${ }^{20}$ note : it might be a later note added by an editor, giving an illustration from his own time, cf. Introd.,

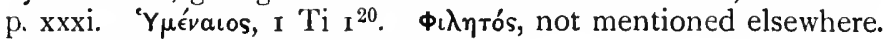

18. ทं $\sigma \tau o ́ x \eta \sigma a v]$ cf. I 'Ti ${ }^{6}$ note.

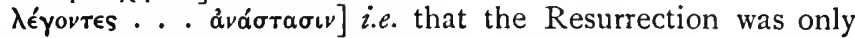
a spiritual Resurrection, which took place at Baptism when the Christian rose to newness of life and a knowledge of the truth. This is analogous to Philo's treatment of the "translation" of

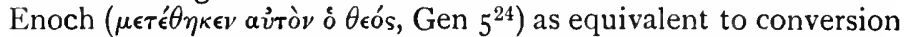
from a lower to a higher stage of moral life (de Abrahamo, cc. 3 and 4 ), and was a natural perversion of the teaching of St. Paul (Ro $\left.6^{1-11}\right)$ and of the Fourth Gospel $\left(\mathrm{Jn} \mathrm{I}^{3}\right)$. It was held by many Gnostics, some denying that the true Christian would ever die (Iren. i. 23. 5 of Menander, "Resurrectionem per id quod est in eum baptisma accipere ejus discipulos et ultra non posse mori sed perseverare non senescentes et immortales"; Tert. de Anima, 5o;

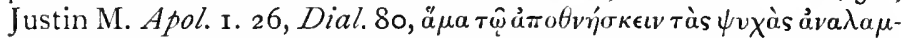

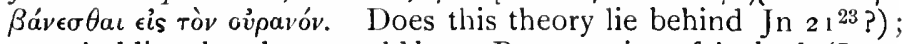
some holding that there would be no Resurrection of the body (Iren. ii. 31. 2 of Simon and Carpocrates, "esse autem resurrectionem 
a mortuis agnitionem eius quæ ab eis dicitur veritatis": cf. I Co I 5 ; Tert. de Res. Carnis, 19). Justin M. (Fragments on the Resurrection, ed. Otto, ii. p. 2 I I) argues fully against this view, and it probably led to the emphasis on the "Resurrection of 'the flesh' or of 'the body,'" in the early Creeds (v. J. Th. St., Jan. 191 7, p. 135).

A quite different explanation prevailed very early-that men do not rise at all, but only live on in their posterity: cf. Acta

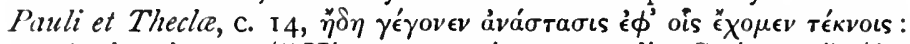
so Ambrosiaster ("Hi autem, sicut ex alia Scriptura" (i.e. probably, The Acts of Paul and Thecla) "docemur, in filiis fieri resurrectionem dicebant"), Pelagius, Theod.-Mops. ("quam in

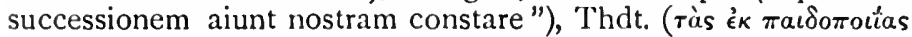

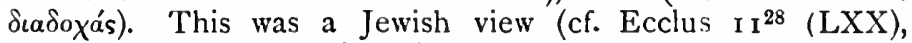
$30^{1 \text { sq9.) }}$, and might have been introduced from Sadducean sources, but it would have been expressed more clearly, e.g., as in Ecclus

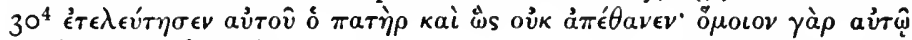

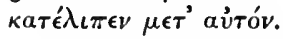

19. Reassurance to Timothy-in spite of the false teachers'

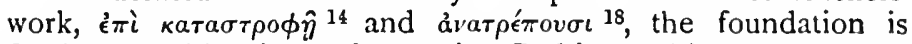
firmly set and has its mark upon it; God knows his own, and they will depart from iniquity.

ó .. $\theta \epsilon \mu$ é $\lambda\llcorner$ 'os] i.e. either Christ Jesus and his Apostles (cf. I Co $3^{11}, \mathrm{Eph} 2^{20}$, Rev $21^{14}$ ): or, more widely, "the Church" (cf. I $\mathrm{Ti} 3^{15}$ ); or "the truth," "the deposit" (Hillard): but the emphasis is on $\dot{\epsilon} \sigma \tau \eta \kappa \epsilon \boldsymbol{v}$ rather than on $\theta \epsilon \mu \epsilon^{\prime} \lambda$ เos.

$\sigma \phi \rho a \gamma i \delta \alpha]$ perhaps simply "inscription"; cf. Ex $28^{36} \dot{\epsilon} \kappa \tau u ́ \pi \omega \mu \alpha$ $\sigma \phi \rho a \gamma i \delta o s ~ a ́ \gamma i a \sigma \mu \alpha$ кvpíov: or, more exactly,"seal," whether the stonemason's mark, denoting workmanship, or the owner's mark, denoting "ownership, security, and destination" (H.D.B. s.v. "Seal"); cf. Jn 627, Eph I ${ }^{13} 4^{30}$.

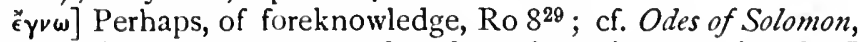
8. I 5 " "I do not turn away my face from them that are mine, for I know them, and before they came into being I took knowledge of them, and on their faces I set my seal " (Dibelius): or more likely (as it is an adaptation of an O.T. phrase), of complete insight

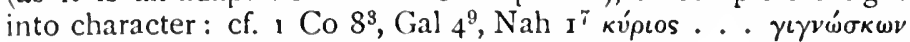

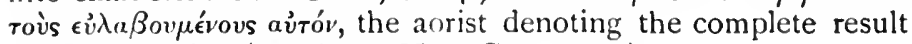
of past watching (Moulton, N.T: Gr., p. I I 3 ).

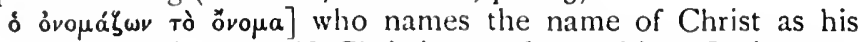
Lord, who calls himself Christian and worships Christ; cf. Lev $24^{16}$, Jos $23^{\top}$, Is $26^{13}$.

Both inscriptions have their origin in the O.T., and probably both in the story of the rebellion of Korah, $\mathrm{Nu}$ i $6^{5} \dot{\epsilon} \pi \dot{\epsilon} \sigma \kappa \epsilon \pi \tau a \mathrm{c}$

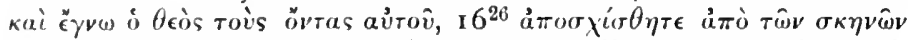

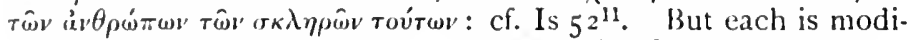

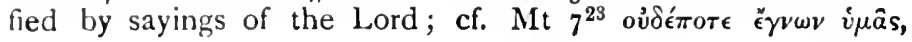




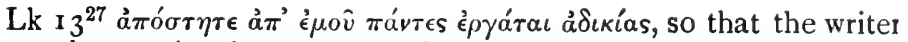
may be quoting from some early Gospel or collection of Christian

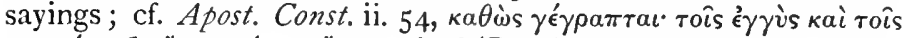

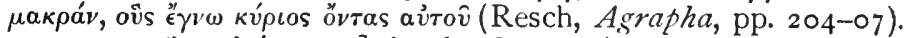

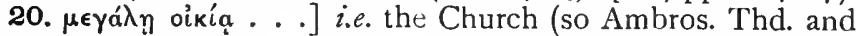
modern Commentators, though many Patristic Comm. interpret it of the world). The illustration is perhaps suggested by Is $52^{11}$

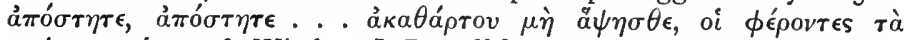
$\sigma \kappa$ év $\eta$ кupíov: cf. IVisd $15^{7}$, Ro $9^{20-23}$. The object is twofold, to teach Timothy patience with varieties of character within the Church, cf. I Co I ${ }^{20-26}$, but mainly to warn him against contact with all impurity and false teaching.

21. ris] any member of the Church, but, especially, any who would be a teacher.

ékкa日. Éauтóv] Keep himself (cf. ${ }^{15}$ and 2 Co $7^{1}$ ) completely ('́) $\kappa)$ pure by separation from these, i.e. from the vessels to dishonour: rovir $\omega \nu$, prob. neuter, though the reference is primarily to the false teachers, "a doctoribus hæreticis," Pelagius. $\sigma \kappa \epsilon \hat{v o s}$

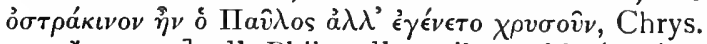

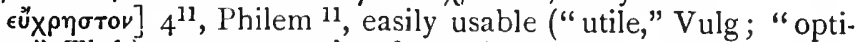

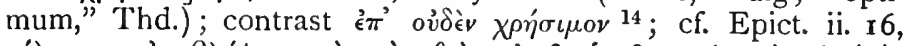

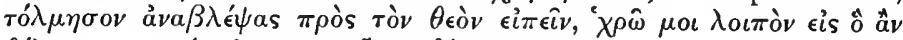

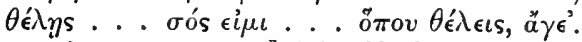

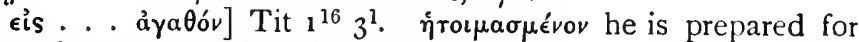

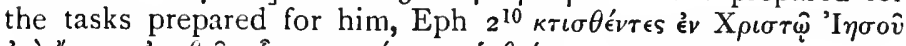

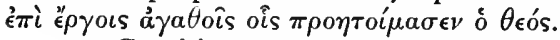

22. Combines the thoughts of $\mathrm{I}^{12}$ and $6^{11}$ (q.v.).

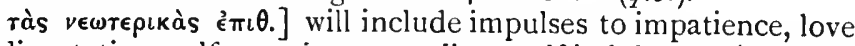
of disputation, self-assertion as well as self-indulgence (cf. illustrations in Wetstein); everything inconsistent with the virtues that follow.

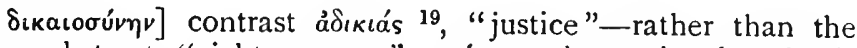
more abstract "righteousness." míruv, the main thought is "fidelity," "trustworthiness" ("integritatem," Pelagius), as the stress is on relations to other men.

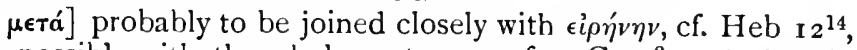

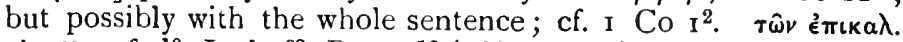
tòv K., cf. ${ }^{19}$, Joel $2^{32}$, Ro ${ }_{10}^{12}$ (ubi v. S.-H.), I Co ${ }^{2}{ }^{2}$. ék $\kappa a \theta$.

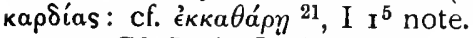

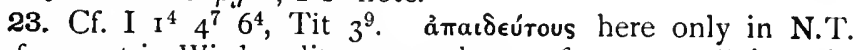
but frequent in Wisdom literature, always of persons, "sine dis ciplina," Vulg.; "ineruditos," Ambros.

24. Soûhov kupíou] here in its special sense of a minister (cf. Ro ${ }^{1}$, Phil ${ }^{1}$ ), probably with a conscious reference to the picture of the servant of Jehovah in Is $42^{1-3} 53$. One who like Christ has to do the Lord's own work of winning and saving; 
cf. G. A. Smith, Isaiah, ii. p. 288 ; Chadwick, The Social Teaching of St. Paul, c. 5 .

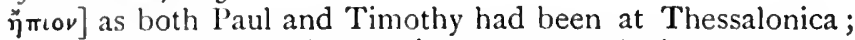

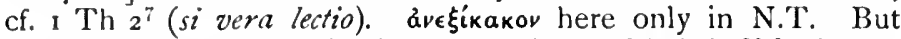

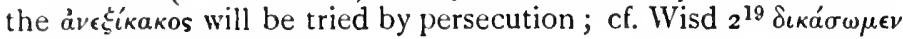

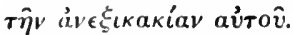

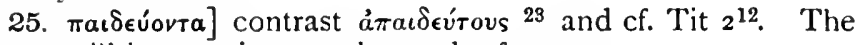
servant will be carrying out the work of grace.

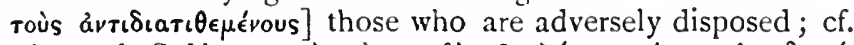

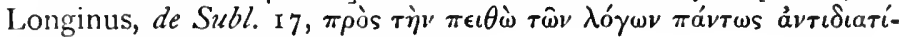
$\theta \epsilon \tau a i$ (Field, Ot. Norvic. ad loc.).

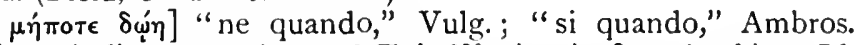

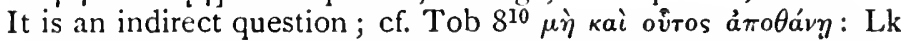

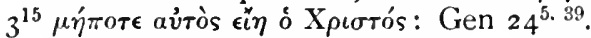

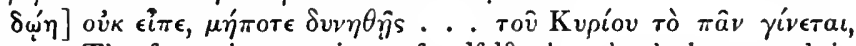
Chrys. The form is optative, cf. $\mathbf{I}^{16-18}$; but both here and in Eph ${ }^{17}$ the subjunctive $\delta \omega \dot{\eta}$ would be more natural ; cf. Moulton, N.T. Gr., p. 55 ; W.-H. ii. p. 168.

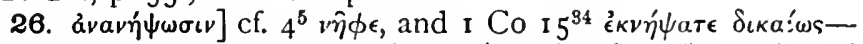

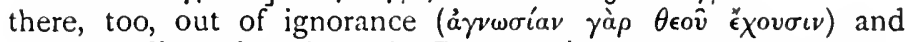
profitless discussion about the Resurrection.

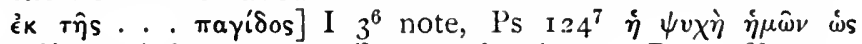

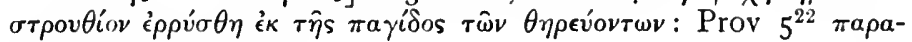

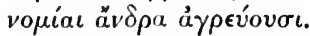

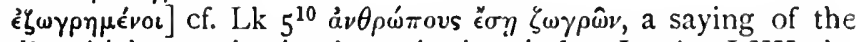
Lord's which may be in the writer's mind. In the LXX the emphasis is nearly always on taking or on saving alive; cf. Jos $2^{13} 6^{25} 9^{20}$.

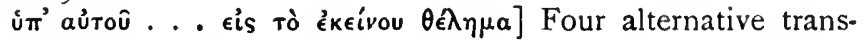
lations are possible.

(i) "Having been captured by the devil to do his will"; cf.

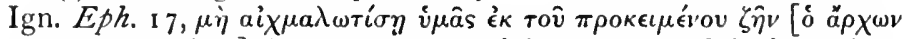

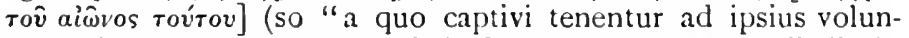
tatem," Vulg., A.V., most Patristic Comm., Holtzmann, 1)ibelius); éк'ívov being substituted for aủrov̂ to suggest a contrast with God whose will they ought to be doing,- " that false master's will,"-cf.

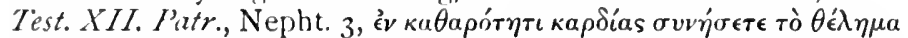

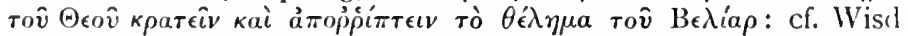
$1^{16} 2^{205}$. But this adds no new thought and does not give its full

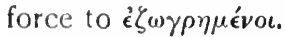

(ii) After having been captured by the devil, they may return to do God's will. "The true master's will," so Bernard, Wohlenlerg; but the same objections hold good to this.

(iii) "Having been captured by God to do His will" (Thphl.

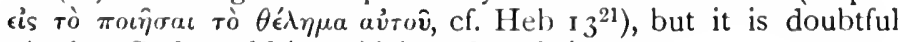

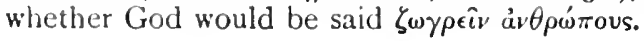


(iv) Having been saved alive, captured into life, by the servant of the Lord to do the Lord's will, and not the devil's (Bengel, Wetstein, R.V. marg.).

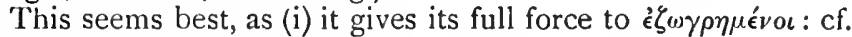
the Inscr. from Apamea, "my greetings to the beloved of God and the newly-caught" (Authority and Archaology, p. 384); cf. 2 Co $10^{5}$ for a similar metaphor.

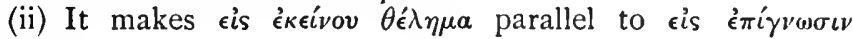
$\dot{a} \lambda \eta \theta \in i a s$.

(iii) It ends on a note of hopefulness and encouragement to Timothy; cf. Chrys. de Sacerdotio, ii. I I $9, \gamma \in v v a i ́ a s$ ov̂v $\delta \epsilon \hat{\imath} \psi v \chi \hat{\eta} s$

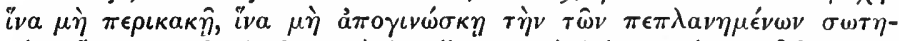

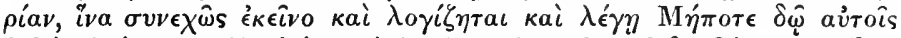

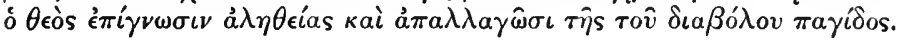

iii. 1-iv. 8. - Further appeal to Timothy for boldness and loyalty, based on the thought of the last days and of the Final Judgment.

Remember, times will grow more difficult $\left({ }^{1}\right)$ : professing Christians will prefer self and pleasure to God $(2-5)$ : false teachers will oppose the truth ; their hearers will be at the mercy of each caprice and each novelty: they will have a temporary success $\left({ }^{6-9} 4^{3.4}\right)$. But I trust you to face persecution and to remain loyal to my teaching, for you have my example to guide you $\left({ }^{10-14}\right)$ : you have Holy Scripture to fit you for your task (15-17): the thought of the Judgment and the coming Kingdom both to awe and to encourage you $\left(4^{1-5}\right)$, and my approaching death will throw all the responsibility upon you $\left({ }^{6-8}\right)$.

In this paragraph there is still the contrast between empty

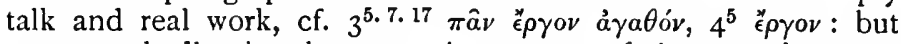
more markedly that between the source of the teaching-the Apostolic teaching, $3^{10} 4^{3}$, and Holy Scripture, $3^{15}$, as opposed to myths, $4^{4}$ : that between the character of the teacher, loyalty to tradition, $3^{14} \mu^{\prime} \epsilon^{\prime} \epsilon$, as opposed to love of novelty, $3^{13} 4^{3}$ : that between the result, in the one case, wisdom and salvation, $3^{15}$, in the other, failure to lay hold of the truth, $3^{7}$, and folly, $3^{9}$.

Paraphrase. But things are not yet at their worst: we have been warned that, as the last days approach, there will be moments very difficult to face. Men's affections will be set not on God, but on self, on money, and on pleasure. This will make them braggarts about what they have, overbearing to those who have not, quick to rail both at God and man, disobedient to parents, with no sense of gratitude to any, no respect for divine things or for human affection, implacable when offended, ready to speak evil of others, with no control uver their own passions, 
no human tenderness, no love for what is good or for those who are good, quite ready to betray their brethren, reckless in speech and action, conceited and puffed up. They will have all the externals of religion, but have long set at defiance its power over their lives. These, too, you must avoid. For it is from a society like this that arise those teachers who creep into private houses and take captive silly women, whose consciences are burdened with past sins, who are at the mercy of caprices of every kind, and so, though always pretending to learn, yet have no power of coming to any knowledge of truth. Yet, though these are their only followers, these men-just as Jannes and Jambres opposed Moses-oppose the truth, men whose intellect is completely debased, who can stand no test as to their faith. But they will not be able to get far; for their utter folly will be quite clear to every one, exactly as that of Jannes and Jambres was shown to be. But you I can trust, for you heartily became my follower; you listened to my teaching, imitated my manner of life; my aims became your aims, my faith your faith, my forbearance, my love, my endurance passed on to you; you know all my persecutions and sufferings; what sufferings befel! me in Antioch, in Iconium, in Lystra ; what persecutions I bore up against: yes, and the Psalmist's words came true, "out of them all the Lord delivered me." Aye, and all who are minded to live a religious life in union with Christ Jesus will be persecuted. And malicious men will grow more malicious, impostors will get worse and worse, deceiving others and deceived themselves. But I appeal to you-stand firm in those truths that you first learned and in which your past life confirmed you, knowing who your teachers were, knowing, too, that from your cradle you have been taught religious teaching from Scriptures which have it in them, if you have true faith in Christ Jesus, to give you the true wisdom which leads to salvation. All Scripture is inspired by God, and therefore is useful for all your taskfor teaching truth, for conviction of sin and refuting of false doctrine, for correction of faults, for discipline of character in the right way. It was given to make every one of God's men fit for his task, for it can fit him completely for every good work.

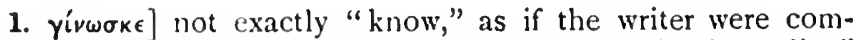
municating a new piece of knowledge, but "recognize," "realize"

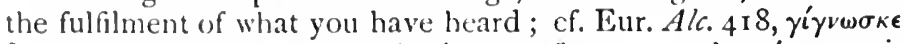

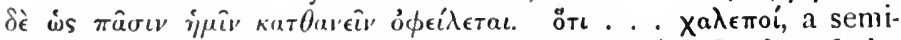
quotation of some eschatological prediction (cf. I $4^{1}$ ), of the woes that would precede the rapovoía: cf. Mk $13^{19}$, Mt $24^{12}$, $2 \mathrm{Th}_{2}{ }^{2}$ ö the last days are already present and Timothy has to face them ${ }^{5}$. 


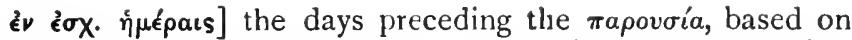

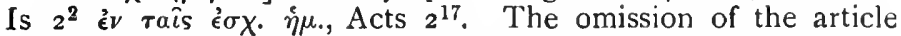
perhaps emphasizes the quality of those days "in days which

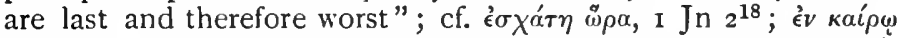

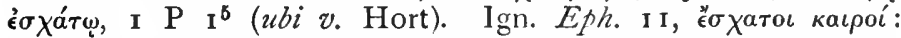
cf. also Gen $49^{1}$ of Jacob in anticipation of his death, $\sigma v v a ́ x \theta \eta \tau \epsilon$

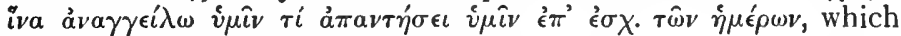
suggests little more than "hereafter."

$x^{\left.a \lambda \epsilon \pi 0^{\prime}\right]}$ hard for teachers, for the servant of the Lord to

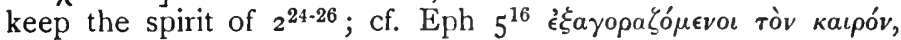

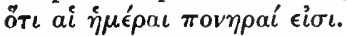

2-5. This list is probably also based on some previous

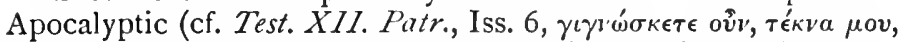

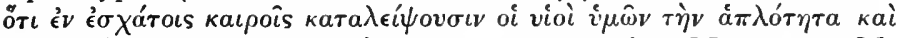

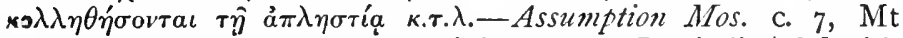
$24^{12}$ ); perhaps also with a reminiscence of Ro i. ii. (cf. ${ }^{5}$ with

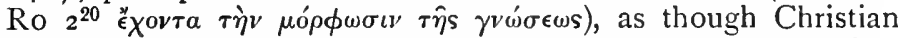
morality was in danger of falling back to the level of heathenism and Judaism. Here, however, there is no stress on individual immorality as in Ro I : the main thought is that the love of self will lead to neglect of the duty to others and to God, nay more, to active wrong-doing to them.

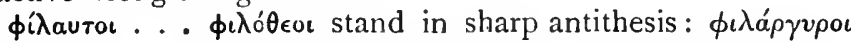
and $\phi \iota \lambda \eta^{\prime} \delta v_{0} \iota$ are subdivisions of $\phi i \lambda a v \tau o \iota$. The true centre of life is changed. Self has taken the place of God, so all sense of the duty to others, whether man or God, disappears. The rest are mainly ranged in pairs: Chrysostom, perhaps fancifully, assumes them to form a climax, each leading to the next after it. фílautos was already a term of reproach in Greek Ethics (cf. Arist. Eth. Nic. ix. 8 for an interesting discussion of the problem in what sense it is a vice), and is placed by Philo in antithesis to

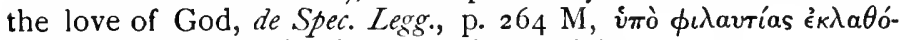

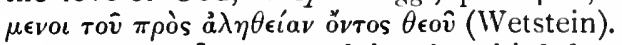

$\phi \iota \lambda a ́ p \gamma u p o r]$ suggested by the chief danger at Ephesus, cf. I $6^{10}$. There, it was the root of all evil; here, it is itself traced back to a root deeper down in human nature, the love of self.

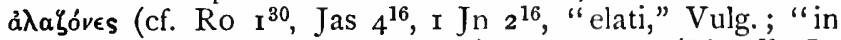
solentes," Ambros. ; "gloriosi," Beza), íтєрฑ́фavo (Lk I" ${ }^{51}$, Jas $4^{6}$, I P $\left.5^{5}\right), \beta \lambda \alpha ́ \sigma \phi \eta \mu o \iota$, all mainly faults of speech, braggadocio about self, boasting of one's own gifts or pretending to those we have not (cf. Arist. Eth. $N$. iv. 7, Rhet. ii. 6; Theophr. Char. xxiii.); scornful arrogance in thought and word towards man and God ('Theophr. Char. xxiv.); outspoken abuse and evil speaking,

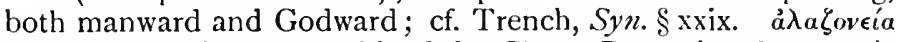

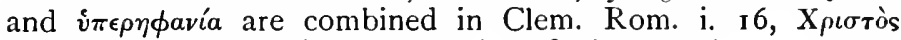

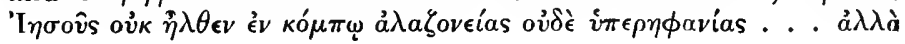




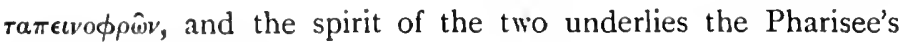
prayer, Lk i $8^{11 .} 12$.

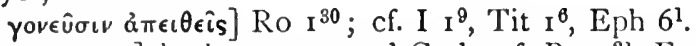

áxápırтor] both to men and God; cf. Ro I ${ }^{21}$, Ecclus I ${ }^{28.29}$,

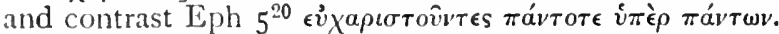

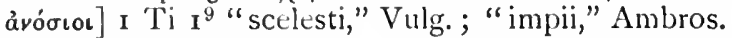

ắropyoı] Ro ${ }^{31}$; cf. I Ti $5^{8}$ "sine affectione," Vulg. ; "sine dilectione," Ambros.

ä $\sigma \pi \circ \delta \delta$ o ] "implacable when offended"; cf. Trench, Syn. $\$$ lii. : but it may also include the thought "untrue to $\sigma \pi 0 v^{\prime} \delta a i$

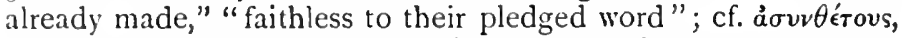
Ro I ${ }^{31}$; " sine pace," Vulg. ; "sine fide," Ambros.

$\delta$ cá $\beta \circ \lambda$ ol] cf. I Ti $3^{11}$, Tit $2^{3}$; it may include the two thoughts "slanderers" and "setters at variance," promoting quarrels in the hope that they may gain from them.

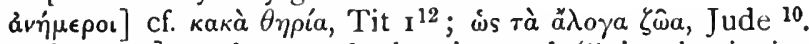

áфi $\left.\lambda^{\prime} \gamma_{a} \theta_{01}\right]$ no lovers of what is good ("sine benignitate," Vulg.), or, of those that are good ("bonorum inimici," Ambros.),

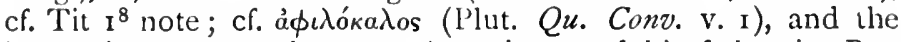
interesting contrast between Antoninus and his father in $P a p$

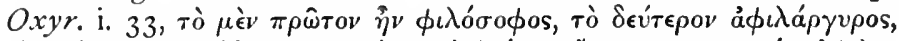

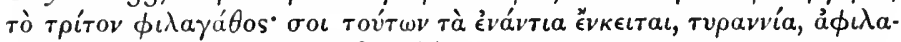

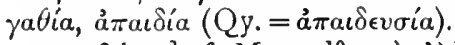

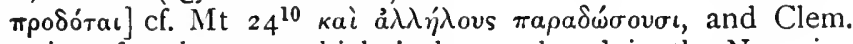
Rom. i. 5 for the part which jealousy played in the Neronian persecution.

$\pi p 0 \pi \epsilon \tau \epsilon i s$ ) hasty, reckless, either in speech (cf. Suidas, $\dot{\eta}$ $\left.\dot{\alpha}_{\chi} \alpha \lambda \hat{u}^{\prime} \omega \tau \cos \gamma \lambda \hat{\omega} \sigma \sigma a\right)$ or in action; cf. Acts $19^{36}$.

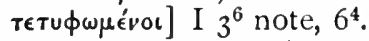

$\phi \iota \lambda \eta^{\delta} \delta$ vo corresponds at the end to $\phi(\lambda a ́ \rho \gamma v \rho o \iota$ at the beginning, both expressions of $\phi^{\prime} \lambda a v \tau o c$ and pointing the contrast to $\phi \iota \lambda o ́ \theta \epsilon o \iota:$ Bengel's comment is "Epicureorum epitheton," but

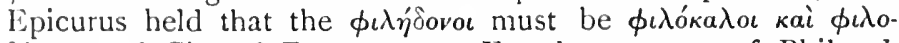
Síkatoı: cf. Cic. ad Fam. xv. I9. For the contrast, cf. Philo, de

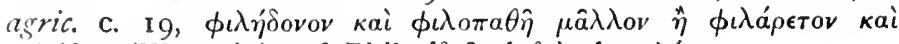

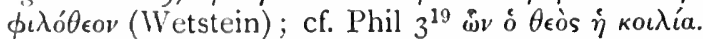

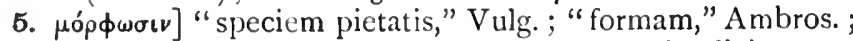
"deformationem," Cypr.: having all externals of religion, or, perhaps, a power of showing such externals. This may include

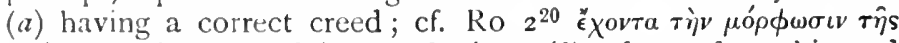

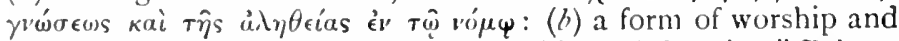
external expressions of religion, "in habitu vel doctrina," Pelag.;

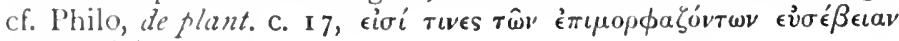
(Wetstein).

kai roútous] those too as well as the controversialists of $2^{23 \cdot 26}$ 


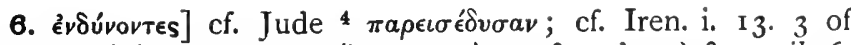

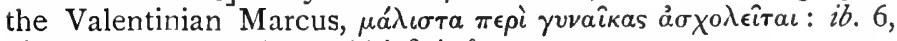

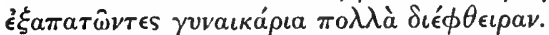

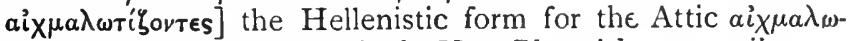
$\tau \epsilon$ éเv, Nägeli, p. 28 ; Rutherford, Neze Phrynichus, ccccvii.

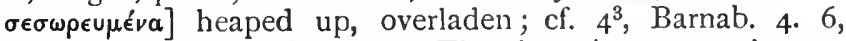

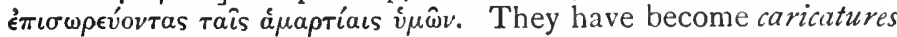
of true womanhood. àyó $\mu \epsilon \nu a$; cf. I Co $12^{2}$ and contrast Ro 814,

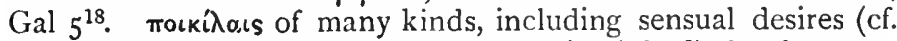
Iren. l.c.), but also the desire for novelties (cf. $4^{3}$ ), for the name of learned women, "mentis et carnis" (Bengel).

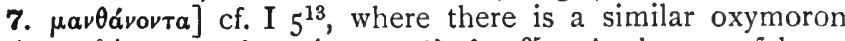

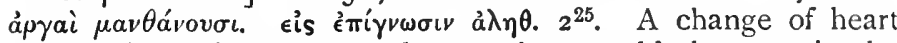
might still enable them to know: they would then regain the

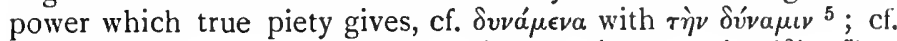

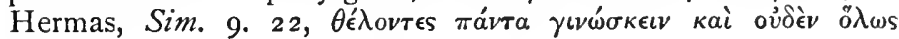

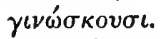

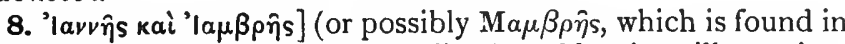
the Western texts and in the Talmud). An ad hominem illustration. They are fond of their Jewish myths and genealogies: well, the nearest analogy to themselves to be found there is that of magicians whose folly was exposed. ôv тpótor may perhaps imply similarity of method, that these teachers used magic arts like the Egyptian magicians; cf. $\gamma^{\prime}$ ites ${ }^{13}$ and Acts $19^{19}$. The reference is to $\operatorname{Ex} 7^{11} 9^{11}$. The names are not found in O.T., Philo, or Josephus, but in slightly different forms in late Jewish Targums, one perhaps as early as the first Christian century (Schechter, Documents of Jervish Sectaries, i. p. 5); in heathen writers (Pliny, Hist. Nat. xxx. I. I I ; Apuleius, Apol. c. xc.), and in several Christian Apocryphal writings, e.g. Evang. Nicodemi, c. 5). Origen twice (ad Matth. $27^{9} 23^{37}$ ) refers to an Apocryphal book with the title "Jannes et Mambres." The names are apparently Semitic, perhaps meaning "the rebel" and "the opponent" (so Thackeray, The Relation of St. Paul to Contemporary Jezvish Thought, pp. 2 I 6-2 r). For fuller details, cf. Schürer, H.J.P. (Eng. tr.) ii. 3. I49, Wetstein, Holtzmann, Dibelius, and W.-H. Notes on Select Readings, ad loc.

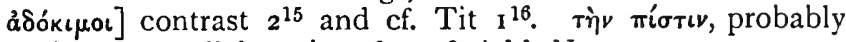
subjective, as parallel to ròv vôेv; cf. Add. Note, p. 20.

9. émi $\pi \lambda \epsilon \hat{\imath} 0 v]$ "farther": or, perhaps (not pressing the comparative, cf. $\mathbf{I}^{18}$ note), "very far."

10. Cf. $\mathbf{I}^{5.6}$. There, the appeal was to his start in life; here, to his start in the Christian life.

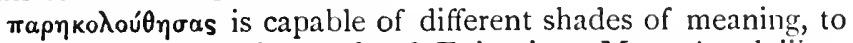
ollow in mind, to understand; cf. Epict. i. 9 ; Marc. Aurel. iii. I, iv. 9, vii. 4 : to imitate; to accompany: here it changes as St. 
Paul mentions his teaching, his Christian virtues, the events of his life. For the list, cf. 2 Co $6^{4} \mathrm{II}^{23}$.

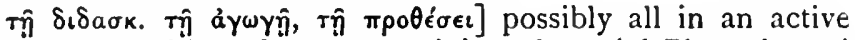
sense-my teaching of you, my training of you (cf. Plutarch, $\pi \epsilon \rho i$ $\pi a i \delta \omega \nu$ a $\gamma \omega \gamma \hat{\eta} \mathrm{s})$, my suggestion of tasks for you to perform, cf.

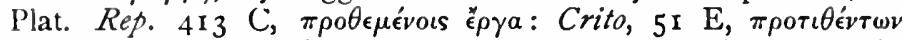
$\dot{\eta} \mu \hat{\omega} \nu . . . \dot{a} \hat{a}^{\nu} \kappa \epsilon \lambda \epsilon \dot{\omega} \omega \mu \epsilon \nu$ (v. Expositor, Nov. 1919); but could $\pi \rho \circ \theta \hat{\epsilon}^{\prime} \sigma \epsilon$ be so used without an explanatory genitive? If not, we must translate-my doctrine (I $4^{6}$ ), my manner of life (cf. Esth ${ }^{20}, 2 \mathrm{Mac}_{4}{ }^{16}$; Pap. Tebt. i. $24^{57} \mu o \chi \theta \eta \rho \grave{\nu}$ à $\gamma \omega \gamma \eta \dot{\eta}$, M.M. s.v.; Nägeli, p. 34), my own purpose (cf. Acts $\mathrm{II}^{23} 27^{13}, 2$ Mac $9^{27}$

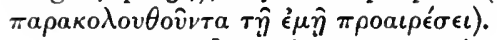

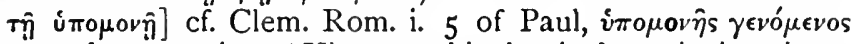

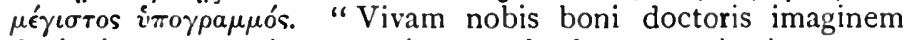
depingit nempe qui non oratione modo formet ac instituat suos discipulos sed pectus quoque suum quodammodo illis aperiat ut intelligant ex animo ipsum docere quæ docet" (Calvin).

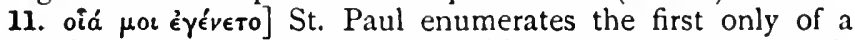
long train of persecutions, 2 Co $\mathrm{Ir}^{30-33}$. Timothy was noi his companion in these; but he doubtless heard of them and followed St. Paul in spite of them. On account of this difficulty Wohlenberg separates this verse from ${ }^{10}$, and treats it as an exclamation. Oh, what I suffered! what persecutions I endured from the first-yet the Lord delivered me!

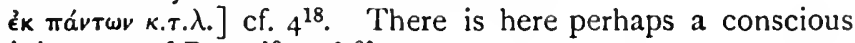
reminiscence of $\operatorname{Ps} 33^{18}$ and ${ }^{20}$.

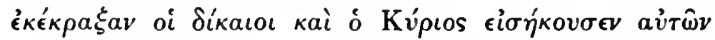

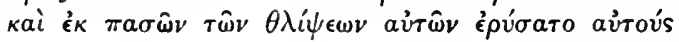

$$
\begin{aligned}
& \pi 0 \lambda \lambda a \grave{i} \text { ai } \theta \lambda \hat{\psi} \psi \epsilon \iota s \text { Tôv } \delta \iota \kappa a i ́ \omega \nu
\end{aligned}
$$

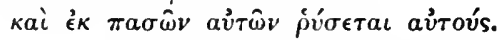

12. Cf. I Th $3^{4} \mu \epsilon \in \lambda \lambda o \mu \epsilon \nu \theta \lambda i \beta \epsilon \sigma \theta a \iota$, Acts $14^{22} \delta \iota \grave{\alpha} \pi o \lambda \lambda \hat{\omega} \nu$

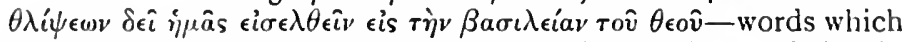
Timothy probably heard when spoken (Hillard). Probably in each case there is a reminiscence of Mt $5^{10.11}$ or some similar saying of the Lord: Prochorus (Acta Joh., p. 83) quotes the words of Acts $4^{22}$ as a saying of the Lord ; cf. Resch, Agrapha, pp. го०, I4 8,278 ; Paulinismus und die Logia, p. 452. Pelagius makes the testing comment: "Timendum ergo nobis est ne non pie vivamus, qui nihil patimur propter Deum."

13 movnpoí] "mali," Vulg.; "nequam," Ambros.; but better "maligni," Bengel. 'The thought is more of malignant harmfulness, willing to persecute, than of moral evil; cf. $4^{18}, 2$ Th $3^{2.3}$, Mt $6^{13}$.

yónтєs] "seductores," Vulg.; impostors, as often in Hellenistic 


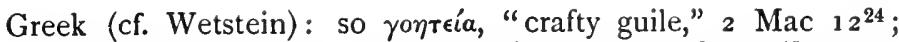
but it may also imply the use of magical arts ; cf. ${ }^{8}$ and ${ }^{15}$ notes.

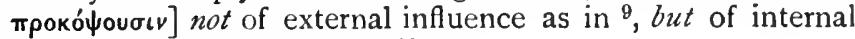
downgrade development as in $2^{16} q . v$.

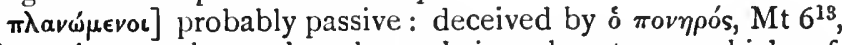
or by other teachers, the phrase being almost proverbial; cf. Philo, de migratione Abraham, c. I 5 (cf. the Egyptian magicians),

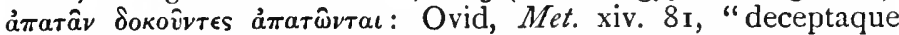
decipit omnes"; Aug. Confess. vii. 2, "deceptos illos et deceptores" ( $v$. Wetstein, Dibelius, for these and other illustrations); cf. 2 Th $2^{11}$.

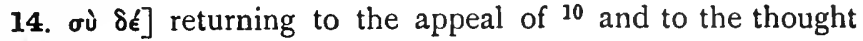
of $2^{16}$.

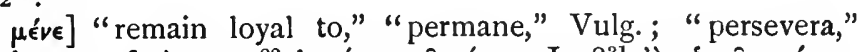

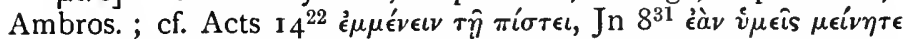

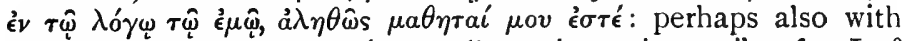

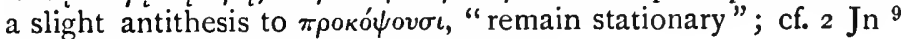

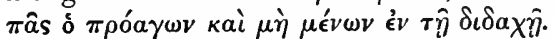

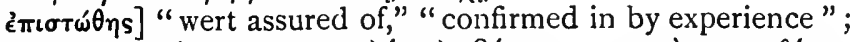

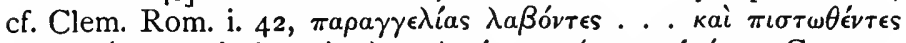

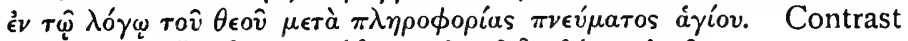

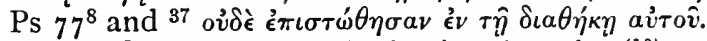

rívwr] will include both the Apostle $\left({ }^{10}\right)$ and the home teachers $\left(\mathrm{I}^{5}\right)$, and, perhaps, the many witnesses of $2^{2}$. For the reading, cf. Introd., p. xxxvii.

15. ảmò $\beta$ pédous] The Jewish parent's duty was to teach his child the Law when in his fifth year; cf. Philo, Leg. ad Caium,

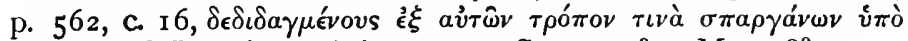

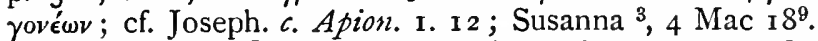

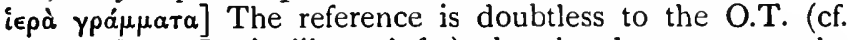
Test. XII. Patr., Levi xiii. 2, infra); but he does not use the

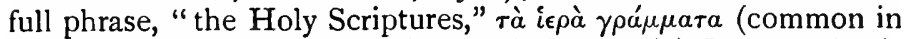

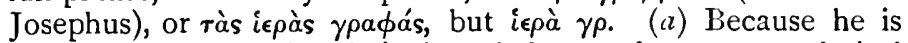
laying stress on Timothy's knowledge, and uses a technical phrase of education-" "religious teaching," "sacred letters"; cf.

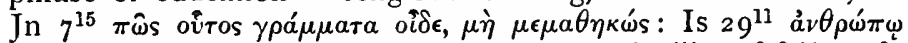

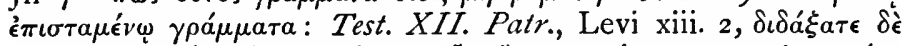

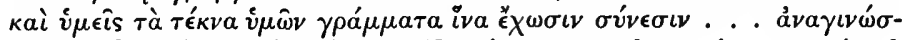

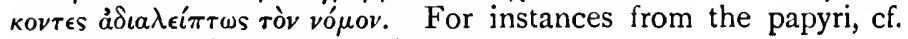

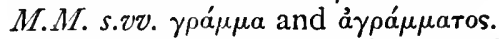

(b) Possibly also he wishes to hint at an antithesis both to the unwritten myths and genealogies of the false teachers and

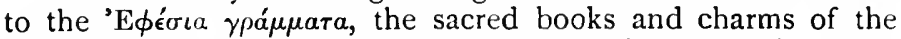
magicians at Ephesus, Acts I $9^{19}$ (Encycl. B. ii. col. I 304). Your text-books were Scriptures, not tradition; they were iє $\rho a$, not $\beta \epsilon ́ \beta \eta \lambda \alpha$. 


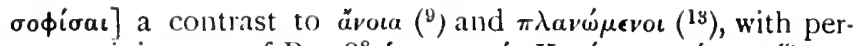

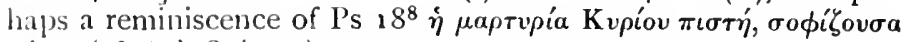

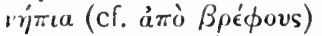

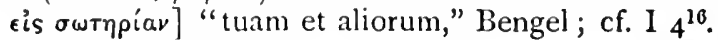
$5^{39-47}$

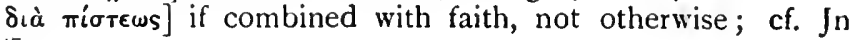

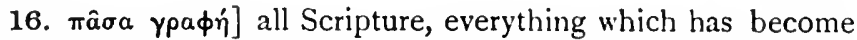
recognized as authoritative Scripture ; cf. $2 \mathrm{P}_{\mathrm{I}}{ }^{20} \pi \hat{\alpha} \sigma \alpha \pi \rho \sigma \phi \eta \tau \epsilon i ́ a$ rpaфijs. Wohlenberg would include any Christian writings which had become so recognized by this time, cf. I $5^{18}$ note; but this is scarcely consistent with ${ }^{15}, \gamma \rho \alpha \phi \eta^{\prime}$ defining more exactly the

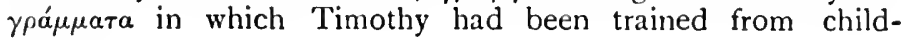
hood.

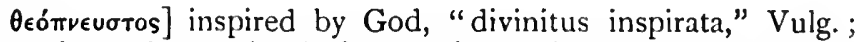
but perhaps also, "with its breath given it by God," so " convey-

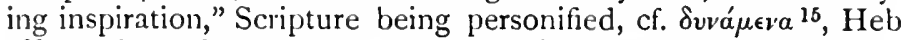
$4^{12}$; so Bengel, "Non solum dum scripta est Deo spirante per scriptores; sed etiam dum legitur Deo spirante per scripturam et scriptura ipsa spirante"; cf. also Cremer, Wörterbuch, s.v. Here it is, perhaps, an attribute, "all inspired Scripture is also useful," but also is not needed in this case; better-a predicate - "All Scripture is inspired by God (contrast $\dot{\epsilon} v \tau o \lambda a i ̂ s ~ a ̀ \nu \theta \rho \omega ́ \omega \omega \nu$,

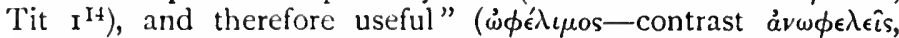
Tit $3^{9}$ ). For the Jewish and Christian conceptions of Inspiration, cf. Westcott, Study of the Gospels (Introduction); Ep. Hebrews (Appendix); Sanday, Bampton Lectures, esp. Lecture II.; Armitage Robinson, Some Thoughts on Inspiration. This is no complete definition of the purposes of Holy Scripture, and cannot be quoted as ruling out other purposes; a different purpose, to give men hope, is ascribed to it in Ro $15^{4}$. Here stress is only laid on such as affect the teacher's task in face of misleading teaching; cf. I $\mathbf{I}^{8-10}$. It should be compared with

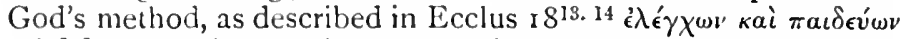

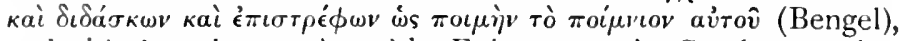
and with the value attributed by Epictetus to the Greek mysteries,

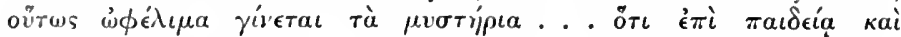

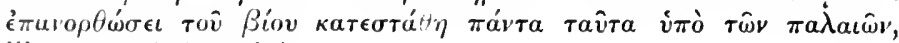
iii. 2 r. 15 (Wetstein).

$\pi$ пòs $\delta\llcorner\delta a \sigma \kappa a \lambda i ́ a v]$ for teaching, "ad docendum," Vulg., rather

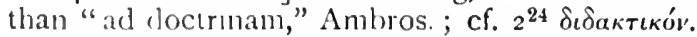

$\left.\epsilon^{\prime} \lambda \epsilon \gamma \mu{ }^{\prime} v\right]$ refutation of false teaching, cf. 'Tit $\mathrm{I}^{9.13}$, and rebuke of $\sin , 15^{: 0}$, 'Tit $2^{15}$; cf. Eph $5^{13}$, Jn $16^{S}$.

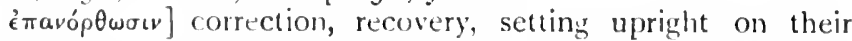

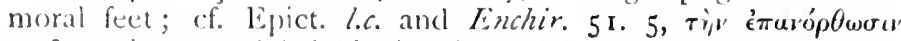

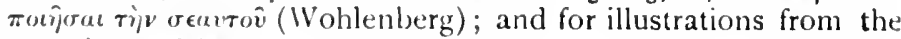
papyri, v. M.M. s.v. 


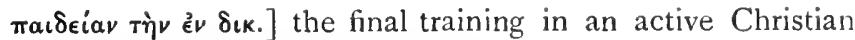

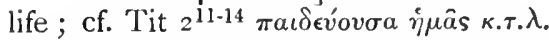

17. äprios] here only in N.T., fit for his task; cf. ${ }^{21} \in$ ยै $\chi \rho \eta \sigma \tau o v$

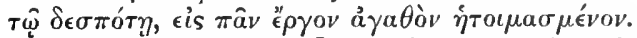

ó roû $\theta$ eoû $a ̈ \nu \theta \rho \omega \pi$ s] Is this the teacher fitted for his task by the study of Holy Scripture? or the pupil fitted for his task by the teacher's training? The context favours the former, cf. I $6^{11}$; but the analogy of $2^{21}$, I $5^{10}$, Tit $3^{1}$, makes the wider reference more probable, by which every Christian is thought of as "a

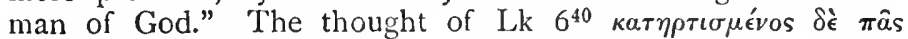

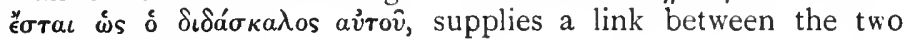
applications.

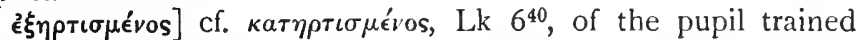

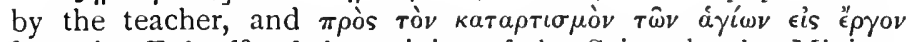

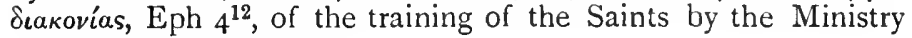
for their work of service.

iv. 1-8. Final appeal based on the coming judgment and the writer's approaching death. You have followed me loyally thus far: I charge you to follow me further, and to remain true to the truth until the end.

As in the sight of God and of Christ Jesus who shall come to judge us all whether living or dead, as you would be ready to welcome $\mathrm{His}$ Appearing, as you would hope to share $\mathrm{His}$ Kingdom, I charge you, preach the message of the Gospel, stand up to your task boldly, in season and out of season, whether you are welcome or unwelcome, refute false teaching, rebuke wrong-doers, pass censure on those who refuse to obey, encourage those who do, never failing in patience, using every method of teaching. For a time will come when men will not tolerate the sound teaching, nay, led, each by his own caprice, they will pile teacher upon teacher, and burden upon burden on their own backs; with ears always itching for some novelty, they will refuse to listen to the simple truth, they will turn aside to listen to all those empty legends. But do you keep calm, keep selfrestrained in all things, be ready to face suffering: your work is to preach good tidings, preach them fully; your task is a task of ministry, perform it to the full. For I shall have to leave you to yourself: ny life-blood is on the point of being poured out as a libation to God: the moment is close at hand when I must strike my tent and be gone. Yes: I have fought my fight, and it was the right fight: I have come to the end of the course: I have kept faith with my Master. So henceforth there is stored up safely for me the crown of a righteous life: the Lord will award it to me on that great day: yes, but not only to me, but 
also to all who have set their hearts on His appearing. We shall be together with Him whom we love.

Note.-(i) This paragraph completes the appeal of $1^{8} 2^{8-13}$, and prepares the way for the request of ${ }^{9}$. For the main thought of it, cf. $2 \mathrm{Th} \mathrm{I}^{5-12}, 2$ Co $5^{1-11}$.

(ii) In $\mathrm{vv}{ }^{6-8}$ there seems to be a conscious reminiscence of Phil ${ }_{1}{ }^{23}{ }_{2}{ }^{17} 3^{13.14}$. If St. Paul is the writer, he may be deliberately recalling to 'Timothy's mind the words of that Epistle, of which Timothy was probably the amanuensis. "What I dictated to you then-that I was willing to depart and to have my life-blood poured out-is now come to the test. I am face to face with it now."

(iii) From Chrysostom onwards commentators have wondered whether St. Paul can be cleared of the charge of self-praise in this passage. It is true that St. Paul is always over self-conscious (cf. I Th $2^{3-8}, 2$ Co $\mathrm{I}^{16-33}$ ); the break in his life by conversion, and the constant opposition which he had to face, made him such; but with St. Paul there is always Xperrós behind the '̇ $\gamma \dot{\omega}$ (Gal $2^{20}$ ), always the thought of the grace which enables him who can do nothing by himself to do all things in its strength (I Co ${ }_{1} 5^{10}$, Phil $4^{13}$, I $\mathrm{Ti}_{\mathrm{I}}{ }^{12}$ ); and to one who so recognizes the power which enables him to be what he is, there is a true selfconfidence, a legitimate self-praise; especially when, as here, the purpose is to give confidence to a younger man to follow. May it not even be that St. Paul, who was constantly "bearing about the dying of Jesus" $\left(2 \mathrm{Co}_{4}{ }^{10}\right)$, may have been thinking of His Master's confidence that His work was completely done, and that $\mathrm{He}$ could confidently commit $\mathrm{His}$ spirit into $\mathrm{His}$ Father's hands? (Lk $23^{46}$, Jn $17^{4} 19^{30}$ ).

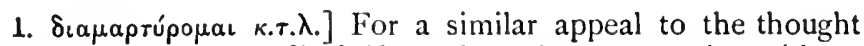
of the judgment, cf. I $5^{21} 6^{18-16}$; and for the construction with an

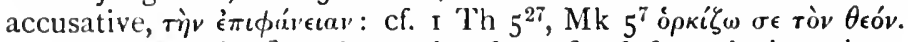
кpiveıv $\zeta$. кai v.] perhaps already a fixed formula in a baptismal creed, cf. Acts $10^{42}$, $1 \mathrm{P}_{4}^{5}$; here perhaps with the personal thought, "you alive and me dead," or "both of us, whether alive or dead."

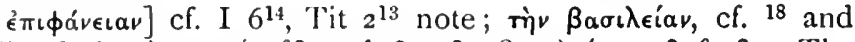

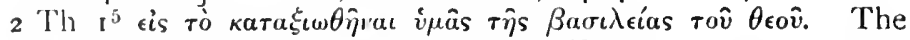
kingdom which we may hope to share, $2^{12}$.

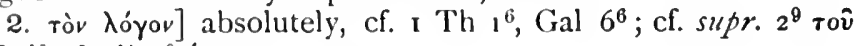

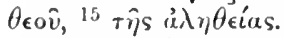

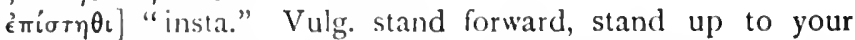

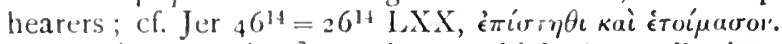

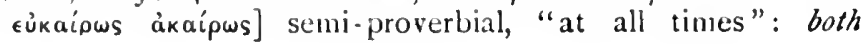


whether or no the moment seems fit to your hearers, "welcome

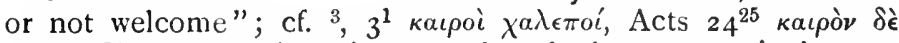

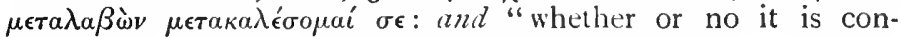

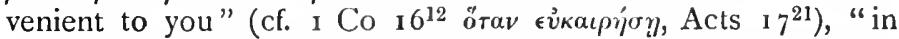
otio vel negotio," "on duty or off duty," "in the pulpit or out of it," "take or make your opportunity." So Paul himself had

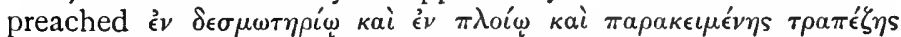
(Thdt.); cf. Sen. Ep. I 2 r, "Et virtutes exhortabor et vitia converberabo; licet aliquis nimium immoderatumque in hac parte me judicet, non desistam" (Wetstein).

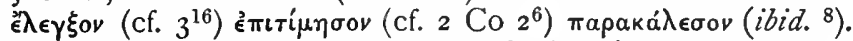
St. Paul's treatment of the offender at Corinth is a good illustration of this combination, $\mathrm{x}$ Co $5^{1-5}, 2$ Co $2^{5-11}$.

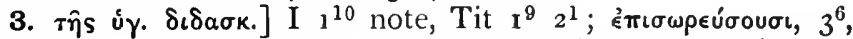
suggests a confused crowd of teachers, each teaching different things, so becoming a burden too heavy for the mind to bear.

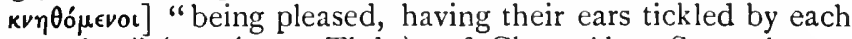

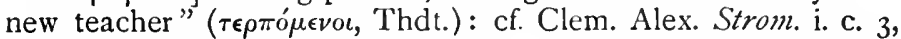

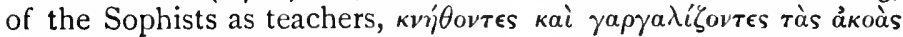
$\tau \hat{\omega} \nu \kappa \nu \dot{\eta} \sigma \alpha \sigma \theta \alpha \iota \gamma \lambda \iota \chi o \mu \epsilon^{v} \omega \nu$ (Wetstein); Lucian, de Saltat. ii. 266,

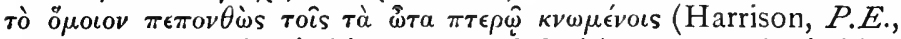
p. I65); or "having itching ears, and desiring to get the itching

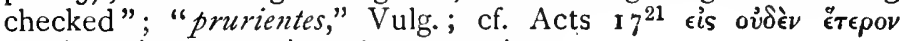

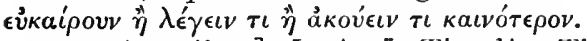

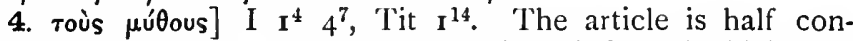
temptuous-those many myths on the knowledge of which they

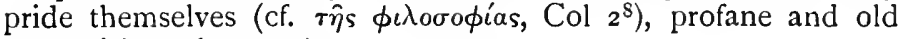
womanish as they are!

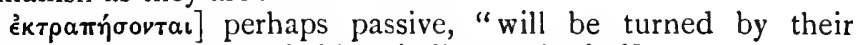
teachers," but more probably middle: cf. I ${ }^{6} 5^{15}$.

5. $v \hat{\eta} \phi \epsilon]$ The word is probably suggested by the self-control of the athlete in training $\left({ }^{7}\right)$; cf. $\hat{\eta} \phi \epsilon$ ws $\Theta \epsilon o \hat{v} \dot{a} \theta \lambda \eta \tau \eta \dot{\eta}$, Ign. $a d$ Polyc. 2; here it implies free from excitement about novelties, self-controlled, vigilant. "Opposed to the morbid habit of mind which craves for fables rather than the naked truth" (Hort on I $\mathrm{P} \mathrm{I}^{13}$ ), cf. I Th $5^{6-8}$, and Marcus Aurelius' description of his

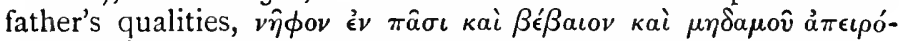

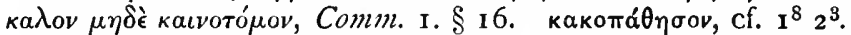

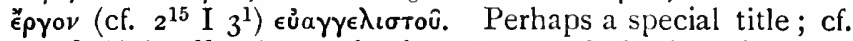
Acts $21^{8}$, Eph 4 11: "one who has to spread the knowledge of the gospel, a missionary"; but the thought of a missionary is

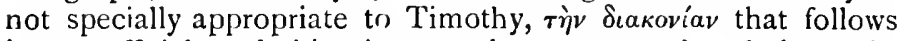
is not official, and this phrase rather sums up the whole teaching of the Epistle than adds a new command. Hence the

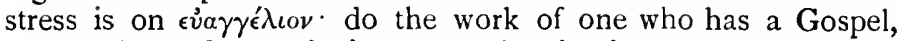
not myths and genealogies, to teach, who lays stress on "Jesus 
Christ risen from the dead" $\left(2^{8}\right)$, and on the whole of my Gospel: cf. $\mathrm{I}^{8 .}{ }^{10} 2^{8}$, I ${ }^{11}$. The command follows каколá $\theta$ ' Tov, for which cf. ${ }^{8}$ note, and $M k \delta^{35}$.

ìv Siakoviav] thy task of service to the Church and its work, cf. ${ }^{11}, I_{1}{ }^{12}$.

$\pi \lambda \eta p o \phi o ́ p \eta \sigma o v] ~ " i m p l e, "$ Vulg., fulfil, carry it out to the end; cf. ${ }^{17}, \mathrm{Lk} \mathrm{I}^{\mathrm{l}}$.

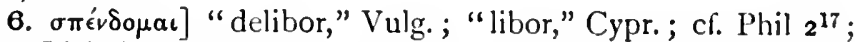

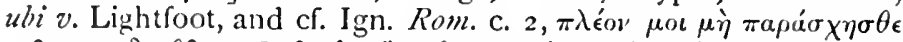

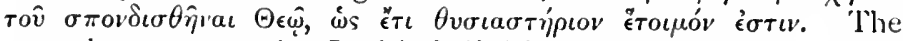
metaphor rests on the Jewish belief in the sacrificial value of a martyr's death; cf. Charles on Rev $6^{8}$. In the similar metaphor as used by Seneca and Thrasea, Tac. $A n n$. xv. 64 ("libare se liquorem illum Jovi liberatori"), xvi. 35 , the comparison seems to be between death and the close of a feast at which a libation was poured to Z $\mathrm{Z} \dot{\mathrm{u}} \boldsymbol{\sigma} \sigma \omega \tau \dot{p} p$. Hence there the active is used; here

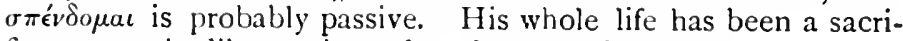
fice: now the libation is ready to be poured upon it.

áva $u ́ \sigma \epsilon \omega s]$ cf. Phil s ${ }^{23}$; Clem. Rom. I. 44. Philo, in Flaccum,

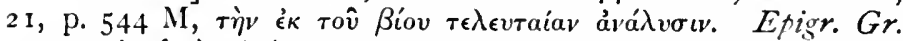

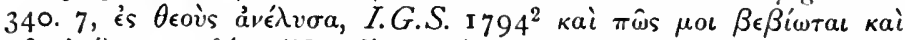
$\pi \hat{\omega} s \dot{\alpha} v^{\prime} \lambda v \sigma a \mu a \theta \dot{\eta} \sigma \eta$ (Nägeli, p. 34). The metaphor is either from a sailor loosing from his moorings or a soldier striking his tent : the

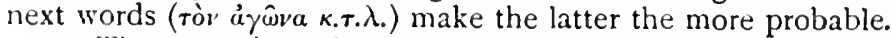

7. The stress is mainly on the perfect tenses: "my fight is over, my task ended." Cf. Verg. AEn. 4. 653-55,

"Vixi et quem cursum dederat fortuna peregi,

Et nunc magna nei sub terras ibit imago,"

but secondarily on his own achievement, "I chose the right contest, I have kept on running, I have kept faith." There is here a true pride in true achievement, in the power given by Christ. Cf. Jn $17^{4}$, I Co $15^{10}$ : stressed here in order to encourage

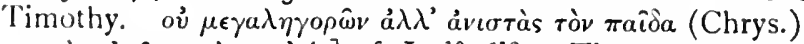

Tòv àywiva tòv ka $\lambda_{o ́}$ ] cf. I $4^{10} 6^{12}$. The metaphor may be from the arena; cf. Philo, Leg. Alleg. ii. 26, p. $86 \mathrm{MI}$, of the fight

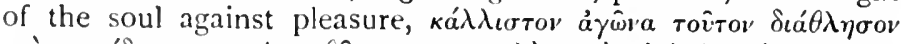

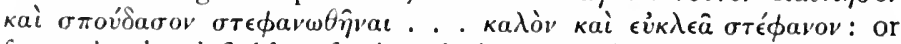
from the battlefield; cf. $2^{4}$ and the Athenian Inscription, Syll.

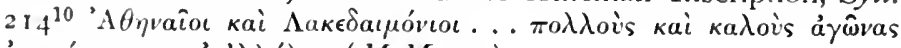

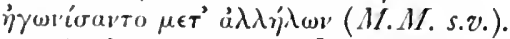

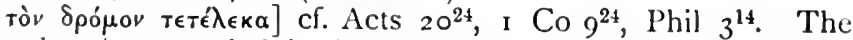
metaphor is expanded in full details in Clem. Alex. Quis dives salvetur, c. 3. Christ has gone before as the $\pi$ pódpopos, Heb $6^{20}$.

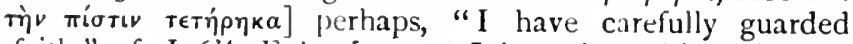
the faith," cf. I $6^{14}$, Eph $4^{5}$; or "I have kept faith with my 
master," "I have been true to my promises": cf. Joseph. B.J.

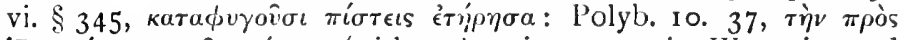

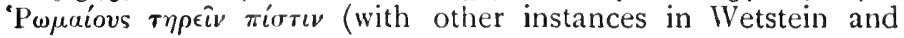
Dibelius).

8. ảmókєtтal] is stored away safely; $\mathrm{cf} . \mathrm{Col}^{5}$ and $O G I S$.

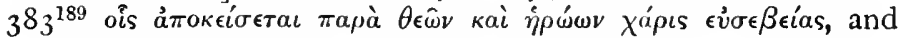
other inscriptions in M.M. s.v.

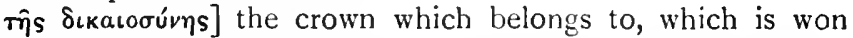
by righteousness; perhaps also the crown which consists in perfect eternal righteousness; cf. Job $33^{26} \dot{a} \pi \circ \delta \dot{\omega} \sigma \epsilon \iota \dot{\alpha} \nu \theta \rho \dot{\rho} \pi$ ots $\delta \iota \kappa a \iota-$

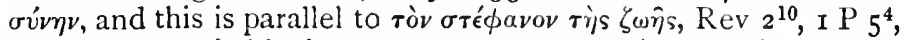
Jas $\mathrm{I}^{12}$, all probably based upon some unwritten saying of the Lord (cf. Resch, Agrapha, p. 252). Cf. Wisd 42, of virtue,

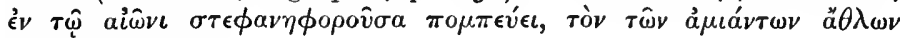

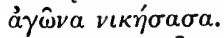

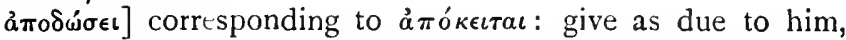
give back what he has deposited with him, what he has earned (cf. $\pi \alpha \rho \alpha \theta \eta^{\prime} \kappa \eta$, p. 90). The thought here is not that of a generous giver, but of a righteous judge. Cf. ${ }^{14}$, Ro $2^{6}$

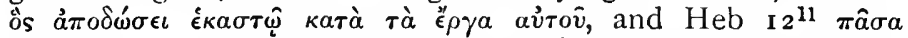

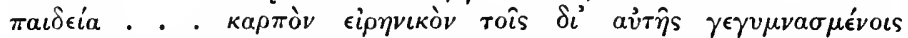

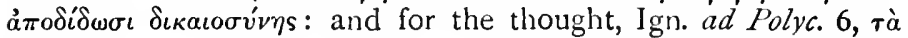

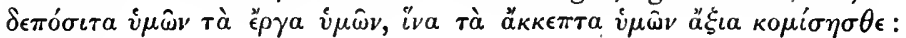
$2 \mathrm{Jn}^{8}$.

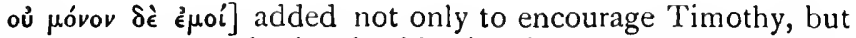
perhaps also to emphasize the blessing in store. We shall be

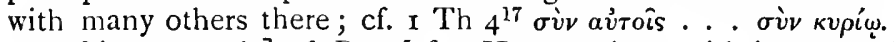

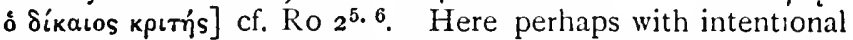
contrast to the unjust tribunal at Rome, I $6^{15}$ note and I $\mathrm{P}_{2}{ }^{23}$.

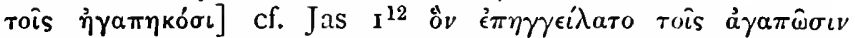
aข่⿻óv: here the tense is viewed from the time of the judgment;

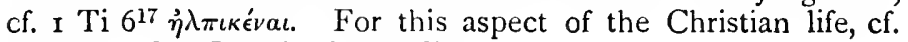
Tit $2^{13}$, I Co $\mathbf{r}^{7}$, and 4 Esdr $7^{98}$ -

"They shall rejoice with boldness,

be confident without confusion,

be glad without fear:

for they are hastening to behold the face of him whom in life they served and from whom they are destined to receive their reward in glory" (Box).

It is suggestive, but scarcely suitable to the context, to combine with this the thought of love for the first Appearing, or love for the many manifestations of Christ to the believer's heart (Chrys.).

9-18. Appeal to Timothy to join him quickly, and assurance of God's protection. 
Paraphrase. Make every effort to come speedily; I am very lonely; Demas deserted me; his heart was set not on the appear. ing of the Lord, but on what this present world can offer, and he went off to Thessalonica; Crescens is gone to Galatia, 'litus to Dalmatia. Luke is with me, but he is single-handed. Pick up Mark on your journey and bring him with yourself, for he is most useful-ahways ready for any service. As for Tychicus, I am sending him to Ephesus. The cloak which I left behind in the Troad with Carpus, bring with you when you come, also my papers, but above all I want the rolls. Alexander, the worker in bronze, showed me much ill-will and did me much harm: I leave him to the Lord's judgment, who will give every man his due reward. But I advise you, too, to be on your guard against him, for he bitterly opposed all that we said. At the first hearing of my case no one appeared to support me; nay, every one deserted me: may it not be laid to their charge. But the Lord stood by my side, and inspired me with strength, that by my mouth the proclamation of the Gospel might be fully made, and all the Gentiles might hear it. Aye, and I was delivered from the very jaws of the lion. The Lord will deliver me again from every harmful deed, and will carry me safe into His Kingdom, that Kingdom of His in the heavens. To Him be all glory, age after age. Amen.

This paragraph is partly an appeal to Timothy, partly an encouragement to him by the stress laid on the Lord's protection of the writer (17. 18). In the latter part the language is perhaps coloured by that of the Lord's Prayer (cf. Chase, The Lord's Prayer in the Early Church, Texts and Studies, i. 3, pp. II 9-22); and throughout there is much similarity with that of the 2 nd l'salm :

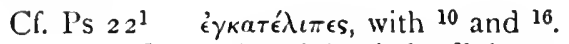

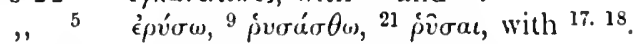

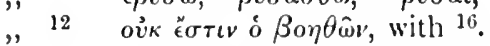

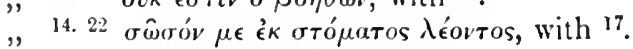

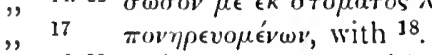

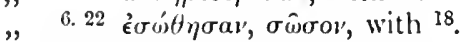

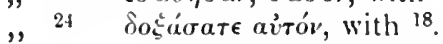

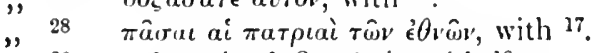

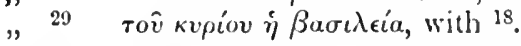

Had St. Paul, like his Master, been saying this Psalm in the hour of desertion?

For the interpretation on the assumption that these verses incorporate earlier notes from St. Paul to 'Timothy, cf. Introduction, p. xxxii. 
10. $\Delta \eta \mu \hat{s}$ (probably a shortened form of Demetrius; it appears also as a woman's name, Pap. Oxyr. iii. 506), $\mathrm{Col} 4^{14}$ (ubi $v$. Lightfoot, who suggests that he was a native of Thessalonica), Philem 24. In the Acta Pauli et Thecla, cc. 1. 4. I2. I4. 16, he appears as a jealous and treacherous companion of St. Paul ; in Epiphan. Har. li. 6, as an apostate. If he could be identified with the Demetrius of $3 \mathrm{Jn} 12$ the opposite was the case, and he, like Mark, returned to true loyalty (cf. J. Th. St., April 1904, pp. $3^{62-66,527}, 5^{28}$ ).

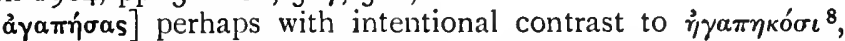
and so ròv vôv ai $\hat{\omega} v a$ to $\tau \dot{\eta} v \dot{\epsilon} \pi \iota \phi a ́ v \epsilon \iota a v$. The suggestion is that his courage failed; cf. Polyc. ad Phil. 9, of Paul and other martyrs,

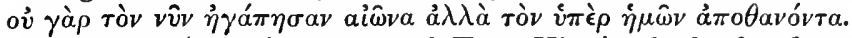

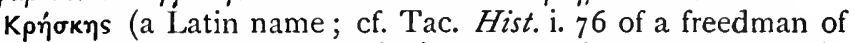
Nero, $A n n$. xv. I I of a centurion), not mentioned elsewhere in N.T. By later tradition bishop of Chalcedon in Gaul (Chronicon Pasch. ${ }^{121}$ ), and founder of the Churches of Vienne and Mayence (Acta Sanctorum, June 27 ; Menologion, May 30).

raגariav] i.e. either Galatia, as always in St. Paul, or possibly

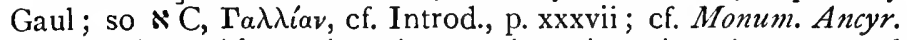

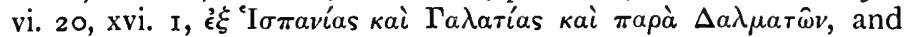
this $w$ as the current Greek name for Gaul in the Ist and and centuries A.D. There is a similar ambiguity in I Mac $8^{2}$.

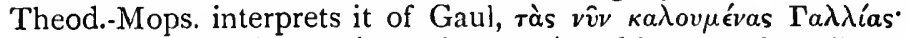

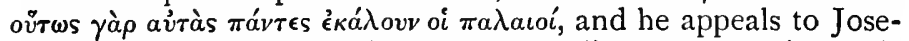
phus' history of the Jews (? de Bell. Jud. ii. I6, v. Swete's note).

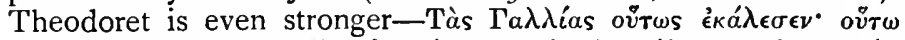

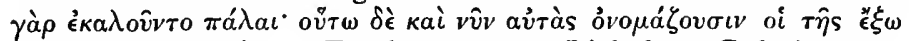

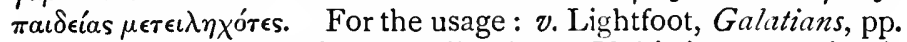
3 note and $3 \mathrm{I}$; Encycl. B., s.v. ii. 1616. If this interpretation is right, it is an indication of St. Paul's interest in Churches west of Rome, and would support the theory that he went to Spain (Zahn, Einl., p. 415).

$\Delta a \lambda \mu a \tau i a v$ (or possibly $\Delta \epsilon \lambda \mu a \tau i a v$, Deissmann, B.S., p. 182), the southern part of Illyricum, cf. Ro $15^{19}$.

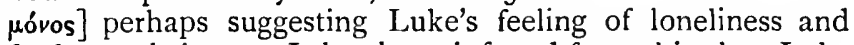
need of some helpers. It has been inferred from this that Luke was the amanuensis who wrote this letter.

11. Mápкov] Acts $\mathrm{I}_{2}{ }^{25}{ }_{1} 5^{37}, \mathrm{Col} 4^{10}$, Philem ${ }^{24}$; for the details of his life, cf. Swete, St. Mark, Introd. i.

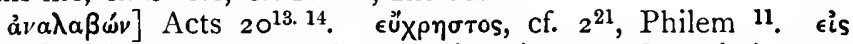

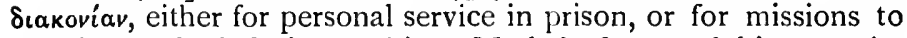
the city, or for help in worship. Mark had proved his capacity

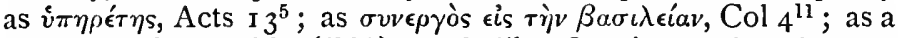
comforter in trouble (ibid.); and, like Onesimus, though once

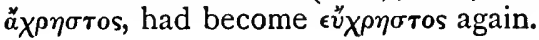


12. Tuxckóv] of Asia (Acts 204) the companion of the first imprisonment, sent with Ephesians and Colossians, Eph 6 $6^{21}$, $\mathrm{Col} 4^{7}$, and by later tradition bishop of Colophonia or of Chalcedon (Menologion, Dec. 9). This statement would have come more naturally after ${ }^{10}$ : perhaps the writer had forgotten it for a moment and now adds it, cf. $\mathrm{I}$ Cor $\mathrm{I}^{16}$; or it may imply that 'Tychicus is being sent to take Timothy's place at Ephesus, cf. Tit $3^{12}$.

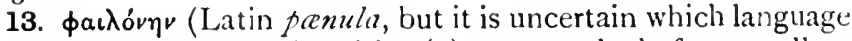
borrowed from the other): either ( $\mathrm{s}$ ) a warm cloak for travelling or winter wear (cf. ${ }^{21}$ ), such as was used by the lower classes at this time, though the use of it was allowed to senators by Alexander Severus; cf. Elius Lampridius, "pænulis intra urbem frigoris causa ut senes uterentur permisit, cum id vestimenti genus semper itinerarium aut pluviæ fuisset" (Wetstein). It is found either in this form or in the diminutive qauvóxıov in the Papyri (Pap. Oxyr. vi. 933 sq. and other instances in Dibelius).

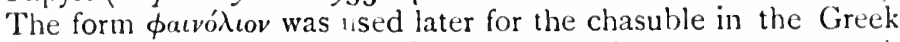
Church, but there is nothing in the context here to suggest such an allusion. Farrar compares the story of Tyndale in prison writing to beg for a woollen shirt and his Hebrew Bible,

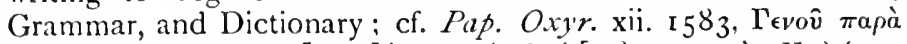

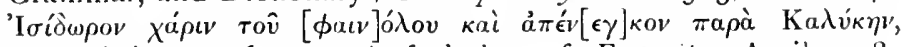
where it is one of a parcel of clothes, cf. Expositor, April 1918: or (2) a woollen wrap for carrying books safely: Chrysostom suggests this as an alternative, and it is adopted by Birt, Das Antike Buchwesen, p. 65; Milligan, N.T. Documents, p. 20; Latham, The K'isen Master, p. 463 note. The context suggests this, though the use is not found elsewhere except in comments on the verse and in the Lexica which may draw inferences from it ; cf. Dict. Christ. Antiq. s.v.

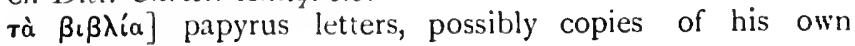
correspondence.

$\mu \epsilon \mu \beta$ pávas] probably rolls of the O.T. (so Thd. Thdt. Milligan, u.s.; Kenyon, Our Bible and the Ancient MSS, P. 9.4); or possibly official copies of the Lord's words or early narratives

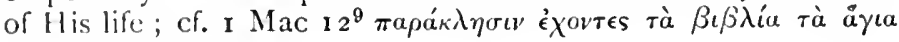
(Thom. Aquin.).

14. Nothing is known of this event or of Alexander, but cf. I ${ }^{20}$. The context would suggest that it happened either at Troas, to which his mind has just gone back, or at Rome at the same time as ${ }^{16}$.

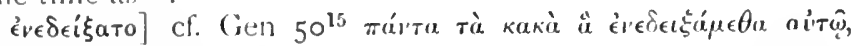
Dan $3^{4 !}, 2$ Mac $13^{9}$.

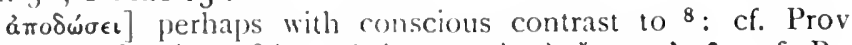

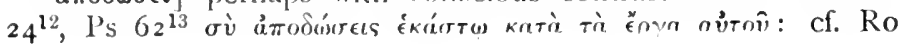


$2^{6} \mathrm{I}^{19}$, and contrast $\mathrm{I} \mathrm{K} 2^{8.0}$. For the reading, $v$. Introd., p. xxxviii.

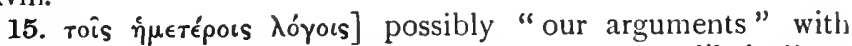
reference to some part of the trial at Rome; or more likely "our words," "our preaching": this opposition might be an element

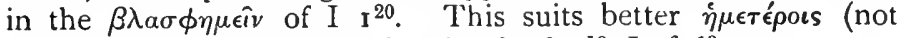
$\left.\epsilon^{\prime} \mu \circ \hat{\imath}\right)$, cf. Tit $3^{14}$; and for the plural, cf. $\mathrm{I}^{13}, \mathrm{I}^{6} 6^{3}$.

16. $\tau \hat{\eta} \pi \rho \omega ́ \tau \eta \dot{~ a n \pi \lambda o \gamma .] ~ e i t h e r ~}(a)$ the first process of the present trial: assuming that he had appeared before the court and the case had been adjourned. For a vivid picture of the scene, cf. H. C. G. Moule, pp. $168 \mathrm{ff}$; or $(b)$ the first trial at Rome at the end of the imprisonment of Acts $28^{30}$; so Euseb. H.E. ii. 22. 3 ; Zahn, Einl. $\$ 33$; Wohlenberg; and this suits better the purpose in ${ }^{17}$ and the sense of entire deliverance.

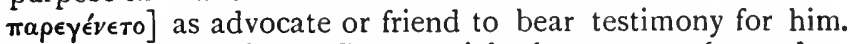

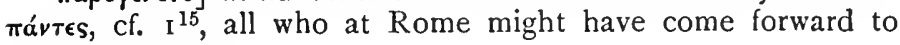
support his case.

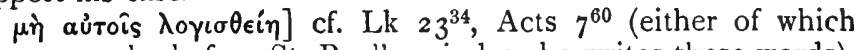
scenes may be before St. Paul's mind as he writes these words),

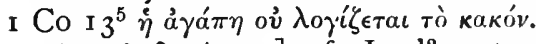

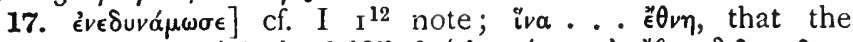

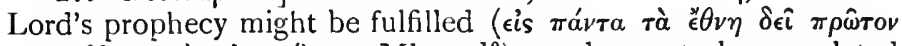
$\kappa \eta \rho v \chi \theta \hat{\eta} v a \iota$ tò $\left.\epsilon \dot{v} a \gamma \gamma \epsilon^{\prime} \lambda_{\iota} o v, \mathrm{Mk} 13^{10}\right)$, and my task completed (Acts $9^{15}$ ). The time of the fulfilment will depend on the interpretation of ${ }^{16}$. It will be either $(a)$ that all the Gentiles who were present at Rome at the time of the present trial might hear his proclamation of the Gospel in his defence; or more probably $(b)$ that after my acquittal at my first trial I might complete my task and all the Gentiles--west of Rome as well as east, cf. Ro $15^{20}$-might hear. This would support the belief that he went to Spain.

ék oтópatos $\lambda$ éovтos] a proverb for extreme danger, probably consciously borrowed from Ps 22 (cf. Ps $7^{2} 35^{17}$, Ecclus $51^{3}$, Esth

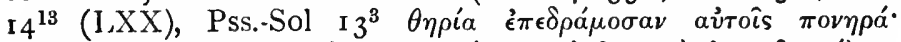

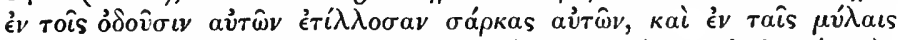

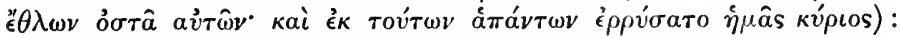
hence there is no need to attempt to identify the lion-whether

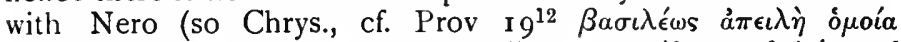

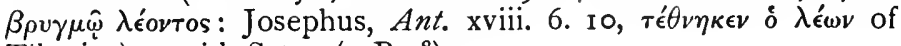
Tiberius) or with Satan ( $\mathrm{P}_{5}^{8}$ ).

18. f́v́⿴\zh11⿰㇇⿰亅⿱丿丶丶] in the future as $\mathrm{He}$ had done in the past, $3^{11}$. ảmò . . movnpov, not "from any wrong-doing, any failure of courage" (as in Dt $23^{9}$, Job ${ }^{8}{ }^{8}$, Test. XII. Patr., Dan 6. 8 ; ả $\pi \dot{o}$

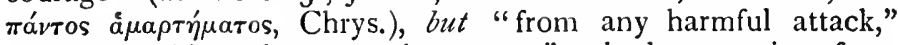
"from anything that may harm me," whether coming from

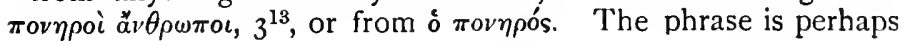




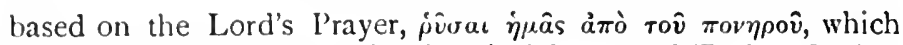
itself may be based on Jewish liturgical forms ; cf. Taylor, Sayings of the Jewish Fathers, p. I42.

тทे v étroupáviov] "regnum Neroniano melius" (Bengel); but the contrast is rather with the present kingdom on earth, Col ${ }^{13}$ "that kingdom whose real seat is in the heavens," cf. ${ }^{1}$. $\dot{\varphi} \dot{\eta} \delta \delta$ óka, so 4 Mac $18^{24}$; cf. Charles, Revelation, $1^{6}$.

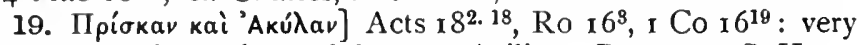
probably freed members of the gens Acilia at Rome; v. S.-H. on Ro $16^{9}$.

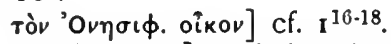

20. "Epartos] probably the same as in Ro $16^{23}$, and perhaps also as in Acts $19^{22}$.

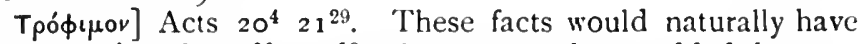
been mentioned in ${ }^{10}$ or ${ }^{19}$ : they are perhaps added here to explain why no greeting is sent to or by them.

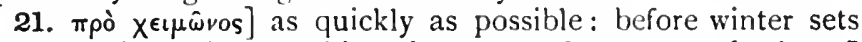
in which will make travelling dangerous for you, and when I shall specially need your presence-and (perhaps) the warm cloak.

These are members of the Roman Church, not companions of St. Paul, cf. 10.11, and probably not of sufficient standing in the city to have appeared in court in support of him (cf. ${ }^{16}$ ). Linus is probably the bishop of Rome (Iren Har. iii. 3). Of Eubulus nothing is known. For an examination of the untrustworthy legends which have grown up round the names of Pudens and Claudia, cf. Lightfoot, Clement of Rome, i. pp. 76-79; Edmundson, The Church in Rome, note C.

22. Probably an autograph blessing, cf. $2 \mathrm{Th}_{3}{ }^{17}$; and indeed the whole paragraph, ${ }^{9-22}$, so full of human personal feeling, may well have been written with his own hand.

$\left.\mu \in \theta^{2} \dot{u} \mu \omega \bar{\omega} v\right]$ so I $6^{21}$, Tit $3^{25} ; v$. Introd., p. xxxiii. Thdt., who read $\mu \epsilon \theta^{\prime} \dot{\eta} \mu \omega \nu$, ends his comment with the prayer, "And may it be our lot, too, to gain that grace through the intercessions of him who wrote and him who received this letter; and may we see them in their everlasting habitations, not from afar, as the rich man saw Iazarus, but dwelling side by side with them and enrolled under their leadership." 


\section{T ITUS}

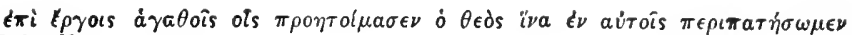
- Eph $2^{10}$.

Historical situation.-(i) St. Paul.-St. Paul has been at Crete, and has left Titus behind to complete the organization of the churches there: he is now apparently on his travels $\left(3^{15}\right.$ oi $\mu \epsilon \tau^{\prime} \dot{\epsilon}^{\prime} \mu o \hat{v} \pi \alpha ́ v \tau \epsilon s$, cf. Gal $\mathrm{I}^{2}$ and contrast I Co $\left.{ }^{1} 6^{19}\right)$ : with him are Artemas, Tychicus, Zenas, and Apollos : the latter two are starting on a journey which will take them past Crete: so St. Paul

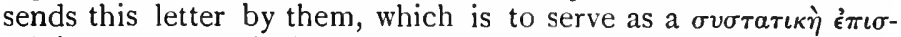
$\tau o \lambda \eta^{\prime}$ for them, and also to prepare 'Titus to join him before the winter, as soon as he receives a visit from Artemas and Tychicus, and meanwhile to guide him in his work and teaching at Crete. There is no indication of the place of writing: it is perhaps a fair inference from ${ }_{1} \mathrm{Ti}^{3}$ that it was somewhere in Macedonia : this would be consistent with his intention to winter at Nicopolis. Zahn (Einl., p. 430) assumes that Titus had written, asking for advice: this is possible, but not necessary.

(ii) The situation at Crete.-There are already groups of Christians, "whole families," ${ }_{1}$, in several cities in the island $\left(\kappa a \tau \grave{a} \pi \alpha^{\lambda} \iota v, \mathrm{I}^{5}\right)$, but their organization is incomplete: there are false teachers, mainly converted Jews, laying stress on the Jewish law, on myths and genealogies, wasting time on worthless controversies; and the standard of life has scarcely risen above that of their heathen neighbours : there are insubordinate, quarrelsome, useless members of the community. St. Paul had begun to organize them and had left Titus to finish his work: he is now authorized to appoint presby ters, $\mathrm{r}^{6-9}$, to guide the teaching, $2^{1 \cdot 15}$, to rebuke with authority, to deal with those who are factious, $3^{11}$ : there is no mention of his ordination for this special work or of its permanence. The bishop is mentioned and presbyters, but it is not clear whether they are separate grades (cf. Introduction, p. $\mathrm{xx})$; there is no mention of deacons, deaconesses or widows, or of any details of the Services of the Church, except the allusion to Baptism $\left(3^{5}\right)$. The Christians are "God's elect" $\left(\mathrm{r}^{1}\right)$, His "peculiar people" $\left(2^{14}\right)$, both titles of the Jewish nation in the 
О.'Т., oi $\pi \epsilon \pi \iota \sigma \tau \epsilon v \kappa o ́ \tau \epsilon s ~ \theta \epsilon \hat{\omega}\left(3^{8}\right)$, the men of faith, and, apparently,

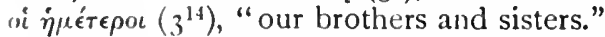

Date-Assuming the integrity and Pauline authorship of the whole, it seems impossible to fit these circumstances into the narrative of the Acts. St. Paul is only mentioned there as visiting Crete on the last journey to Rome: he stayed there some time (Acts $27^{8.9}$ ) : this might be the visit referred to in $1^{5}$, and the Epistle might have been written during the imprisonment of Acts 28 ; but there is no evidence of Titus being with him on that journey, and, with the exception of Tychicus, his present companions are different from those in the letters from Rome. Moreover, the likeness of style with I and II Timothy points to a later time after the release from the first imprisonment. The greater likeness with I $\mathrm{Ti}$ (as compared with $2 \mathrm{Ti}$ ) suggests that it was written very nearly at the same time as it, and its greater simplicity suggests that it was the earlier of the two and therefore the earliest of the three Pastorals.

On the theory that the Epistle is a later expansion of a genuine lauline fragment, that fragment, consisting only of the adtress and the personal messages, $3^{12.15}$, might have been written by St. Paul while in Macedonia to Titus still at Corinth, i.e. after writing 2 Co IO-I 3 , and before writing 2 Co $\mathrm{I}-9$ (so Harrison, P.E., p. I I5); and the expanded letter will fall at the end of Cent. I, or the beginning of Cent. II. In this case, it would probably be later than 2 Ti but earlier than $\mathrm{I} T \mathrm{Ti}$, as being simpler and imply. ing a less organized Church; but $v$. Introduction, p. xxxiv.

Aim and value.-The chief aim of the writer is to raise the level of character; but whereas in I and II Ti the main stress was on the character of the officers of the Church, on the teachers, here it is also and mainly on the character of the taught. He is dealing with communities in a fairly early stage of Christian life and with le'ss civilization than the Church at Ephesus. The population of Crete had always been very mixed (cf. Hom. Od. 19. $172-77)$ : there had been constant rivalry between city and city: in the first century before Christ it had been the centre of piracy, subdued with difficulty by the Romans: since 67 B.c. it had been part of a Roman province, and at this time there was still a mixed population, consisting of the Roman officials, the natives, and a considerable colony of Jewish traders (Philo, Leg. ad Gaium, $3^{6}$; cf. I Mac i $\left.{ }^{33}\right)$; it still supplied mercenaries for foreign armies (Joseph. Ant. xiii. 4. $\$ 3$; Livy, xliv. 45), and the inhabitants had a bad name for treachery and for love of money

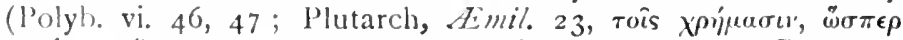

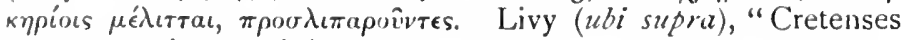
spem pecuniæ secuti").

Hence the writer lays stress on the duties of members of a 
family, and on those of citizens of a State. The true character of each member is defined: the duty of obedience to authority, of active service to the community, of honest trading, of a peaceable temper, are insisted upon. This is exactly in the spirit of St. Paul's stress on family life in Col. and Eph., and on obedience to magistrates in Rom. : it is the natural language of the Roman citizen anxious to strengthen the hands and to carry out the policy of the Roman Government towards its provincials (cf. Ramsay, St. Paul the Traveller and Roman Citizen, c. 6). To secure such a character the foundation is laid in sound, wholesome teaching : the grace of God disciplines and educates: Christ's self-sacrifice was made for this very purpose : God's own graciousness and love for man is the model for the Christian's imitation and supplies the strength for it. The Church is the school of character.

\section{ANALYSis.}

$1^{1-4}$ Salutation. Paul the apostle of a common faith, a true knowledge, a hope of eternal life, to Titus a genuine son in the faith.

$I^{5}-3^{11}$ Commands to Titus.

(a) With regard to the ministry ( $\left.\mathbf{1}^{5-16}\right)$.

Presbyters to be appointed in every city, but only men known to be of high character in their family life to be chosen, ${ }^{5.6}$.

Reason.-Because the bishop has to regulate God's family, to teach sound teaching, and refute opponents, ${ }^{7-9}$. Such opponents are to be sharply rebuked, as upsetting others, insubordinate, wasting time on foolish discussions, and as untrue to their profession, $10 \cdot 16$.

(b) With regard to the various classes in relation to their family life $\left(2^{1-15}\right)$.

Titus is to teach and enforce a true standard of character on the elder men, ${ }^{2}$ :

The elder women, who are to train the younger women.

Reason. - That God's word be not evil spoken of, ${ }^{3-5}$.

The younger men, to whom he is to be himself the example.

Reason.-That opponents of Christianity be put to shame, ${ }^{6-8}$.

The slaves, to be obedient, honest, thoroughly loyal to their masters. 
Reason.-That they may adorn the Christian teaching, 9.10.

Such character is made possible by the grace of God, bringing salvation and training us to a true life here, with our eyes fixed on the appearing of Christ, the whole purpose of whose self-sacrifice was to save us from lawlessness and make us eager for excellence, ${ }^{11-14}$.

(c) With regard to the behaviour of Christians to the heathen world, to their life as citizens, $3^{1-8}$.

'They must be reminded (I) to be subordinate to authority and active in good works, (2) to be courteous and gentle to all men, $1 \cdot 2$.

Reason.-God's loving-kindness to us has raised us from the old heathen life by the rich outpouring of the Spirit to a hope of eternal life; hence all believers must take the lead in good works and live useful lives, ${ }^{3-8}$.

(d) In regard to teaching. Titus is to avoid foolist. discussions and controversies; to rebuke; but if rebuke fails, to have nothing to do with factious men, ${ }^{8-11}$.

18. 13 Personal messages.

${ }^{14}$ Final appeal for useful, fruitful lives.

15 Greetings.

I $^{1-4}$ Paraphrase. Paul to Titus his true son in the faith.

Paul writing as a slave of God, bound to obey his Master's command, yet, more than that, as one formally commissioned to speak for Jesus Christ-Paul, whose only standard is the faith shared by God's elect and a knowledge of truth such as makes for godliness, whose whole work rests on hope of eternal life, that life which the God who cannot deceive promised to man long ages past, aye, and at the right moment $\mathrm{He}$ published abroad His message in a proclamation, which was put as a sacred trust into my hands in virtue of a direct command from God, your Saviour and mine, writes to you as a son whom he knows that he can trust, a son in a common faith. Grace and peace be with you from God our Father and Christ Jesus ourSaviour.

The address is unusually long, but compare Gal $I^{1-5}$, Ro $I^{1-7}$ $16^{25-27}$; it might have been compiled with a reminiscence of those passages, but a compiler would naturally have been simpler, and the changes are more nalural in the same author writing at a different time. 
It strikes two notes-(i) a personal note, a letter from a father to a son $\left(\dot{\epsilon} \gamma \grave{\omega} \ldots . \tau^{\prime} \kappa \nu \omega\right)$; (ii) more strongly an official note, instructions from an apostle to a delegate (ámócrodos... $\left.\gamma \nu \eta \sigma i \omega \tau \tau^{\prime} \kappa \nu \omega\right)$ : laying stress (I) on his duty rather than on his

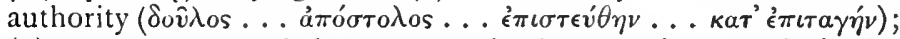
(2) on the nature of the message he has to give. This is the point mainly emphasized; it is no novelty, no unfounded statement, no aimless discussion, but rooted in the past and looking forward to the future, and affecting a godly life. o̊ $\rho \alpha \pi \hat{\omega} s \quad \gamma \in \epsilon \in \iota$

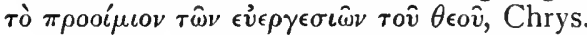

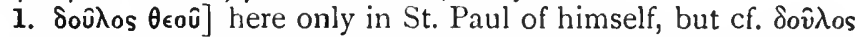

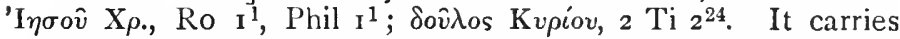
the thought of obedience beyond Jesus Christ to God, "the God of our fathers who had chosen him to know His will " (Acts $\mathbf{2 2}^{\mathbf{1 4}}$ ), and so places him on a level with Moses and other O.T. servants (Dan 910.11), especially with "the servant of the Lord" of Isaiah ; cf. 2 Ti $2^{24}$ note. Pelagius' comment, "servus Dei non peccati " (cf. $2^{14} 3^{3}$, Ro $6^{15-23}$ ), is suggestive, and perhaps consciously present.

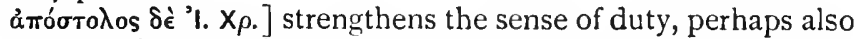
to enforce his authority. "Scribit non quæ. Titus in cubiculo solus legat sed quæ proferat in publicum," Calvin.

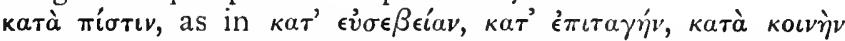
$\pi i ́ \sigma \tau \iota v, \kappa a \tau a$ gives the standard; but the application of the standard differs with the context. Here it may include $(a)$ chosen in

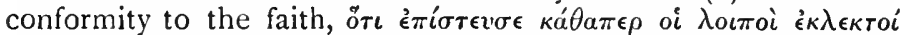
(Theophylact); $(b)$ preaching by that standard, "to preache the

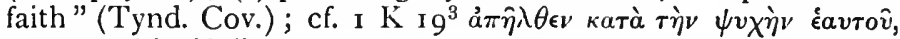
"to save his life."

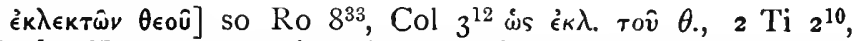
I $\mathrm{P} \mathrm{I}^{1}$. The phrase springs from the O.T., being based on the choice of Israel as a nation, charged with a message for the

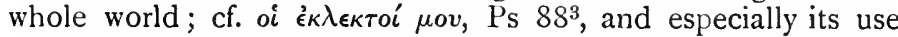
with regard to Israel as the Servant of the Lord, Is $43^{20} 45^{4}$ $65^{9}$ etc. Hence it here may include the thought of the Jewish nation in the past, and lays stress on the sense of God's choice of the Church and of its duty to carry His Truth to the world.

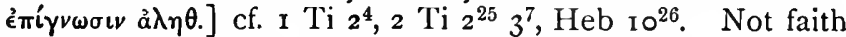
alone, but knowledge also is necessary for an apostle: cf. Ro $10^{2}$

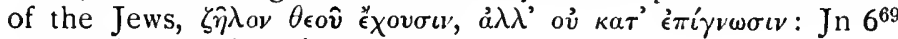

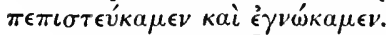

$\tau \hat{\eta} s$ к $a \tau^{3} \in \dot{u} \sigma \epsilon \beta$.] cf. I 'Ti $6^{3}$, contrast $2 \mathrm{Ti} 3^{5}$.

2. $e^{\prime} \pi^{\prime} e^{2} \lambda \pi i \delta \imath \zeta$.] cf. I $\mathrm{Ti} 4^{9.10}$.

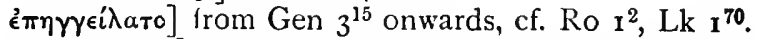

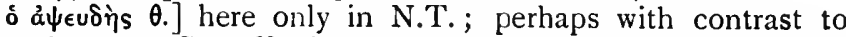
the $\psi \epsilon \hat{v} \sigma \tau a \iota$ at Crete ${ }^{12}$; but $\mathrm{cf}_{2} \mathrm{Ti}^{13}, 2 \mathrm{Co} \mathrm{I}^{19.20}$, Martyr. 


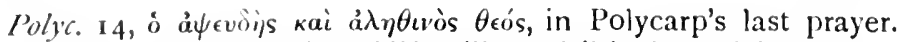
The God whose promise of life will not fail in face of death.

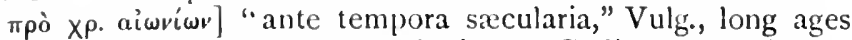
past, age-long periods ago, not referring to God's purpose before time began, as in $2 \mathrm{Ti}^{9}{ }^{9}, \mathrm{Eph} \mathrm{I}^{4}$, but to definite promises (cf. Ro $9^{4}$ ai $\dot{\epsilon} \pi(\gamma \gamma \epsilon \lambda i a)$ made in time.

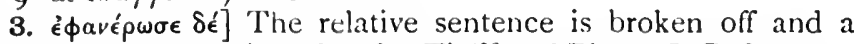
direct sentence substituted; cf. I Ti $6^{12}$ and Blass, G.G., § 79. I I. Possibly the relative sentence is continued down to idiots, "which

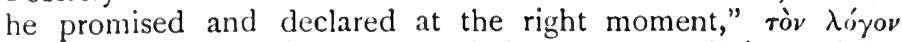

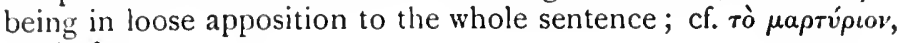
I $\mathrm{Ti}_{2}{ }^{6}$.

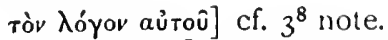

xalpois isios] 'The thought of the Incarnation taking place at the right moment in the world's history is a favourite one

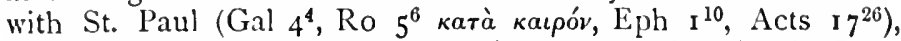
springing from apocalyptic expectations, sumned up by the Lord

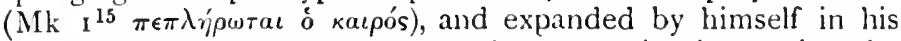
philosophy of history, Ro $1-3$; perhaps consciously meetirg the

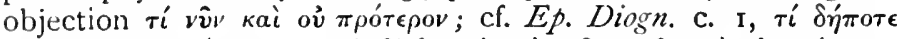

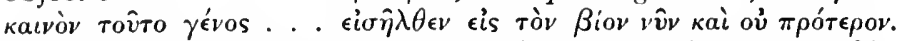
'The nearest analogy to the phrase is also Pauline, katpw iót Gal $6^{9}$; the exact phrase is peculiar in N.T. to P.E. (I Ti $2^{6}$ $6^{15}$ only); both words are ambiguous : (i) is ioious = "at its right

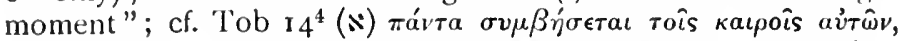
Lev $23^{4} 26^{4}$, Ps $1^{3}$, Gal $6^{9}$; Justin M. c. Tryph. c. 1 3 I, $\pi \alpha^{\prime} v \tau \alpha$

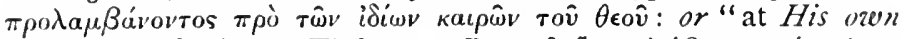

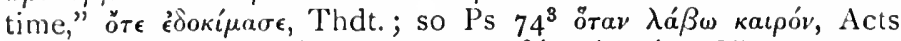

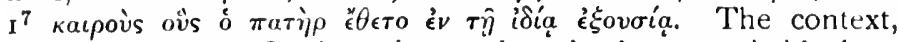
with its stress on God's action, makes the latter probable here and in $1 \mathrm{Ti}^{15}$, the former in $\mathrm{r} \mathrm{Ti}^{6}$; but the two thoughts lie close together, and were perhaps not kept distinct. (ii) Is the plural only an idiomatic usage, practically equivalent to the

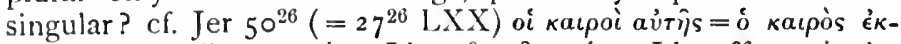

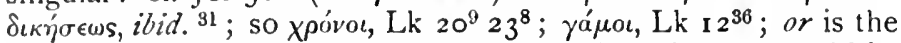
plural to be pressed? In the former case the reference would be to the whole life of the Lord ( $\left.\mathrm{cf.Heb} \mathrm{I}^{1}\right)$; in the latter, to the various points in the life, the birth $\left(\mathrm{Gal}_{4}^{4}\right)$, the death $\left(\operatorname{Ro~} 5^{6}\right)$, and to the subsequent apostolic preaching ( $\mathrm{I} \mathrm{Ti}^{6} 3^{16}$ ). The contrast with $\chi^{\text {oóvo }}$ aicurio and the analogy of Ro $16^{26}$ favours the latter view.

For the preparation for Christ in History, cf. Lux Mundi, c. 4,

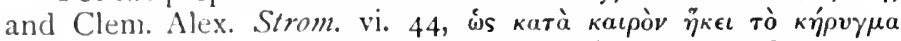

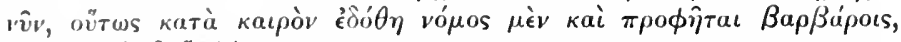

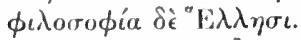

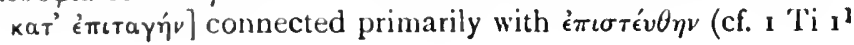


note), but Ro $16^{26}$ suggests a further connection with é $\phi \alpha \nu$ ép $\omega \sigma \epsilon$. The command to St. Paul to preach the gospel is part of the command of the eternal God to manifest the Christ ; cf. I $\mathrm{Ti}^{7}$.

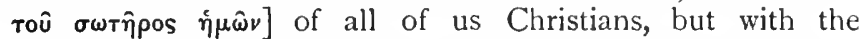

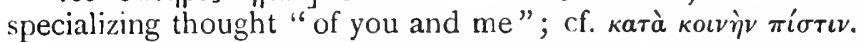

4. Tíw ] Personal references to the life or character of Titus are very slight in the Epistle; such as occur are quite consistent with the little that is known of him elsewhere. $\mathrm{He}$ is never mentioned in the Acts. A Gentile by birth, he was perhaps converted by St. Paul on his First Missionary Journey at Iconium (Acta Pauli et Thecla, c. 2). He is first mentioned in the Epistles as accompanying St. Paul on the visit from Antioch to Jerusalem, mentioned in Gal 2. There his case was apparently taken as a test case of the need of circumcising Gentile converts, and (although the reading and meaning of $\mathrm{Gal} 2^{3-5}$ are not quite certain) the demand was almost certainly successfully resisted. Later he becomes St. Paul's delegate to Corinth: he begins there to organize the Collection for the Saints ( 2 Co $8^{6-10}$ ); he goes later, perhaps taking the severe letter of $2 \mathrm{Co} 2$ and 7 , to deal with the refusal of that Church to obey the Apostle: he deals successfully with the difficulty and returns to gladden the Apostle's heart in Macedonia; he then gladly returns to complete the Collection ( 2 Co $\left.8^{16}\right)$. On another occasion he is sent on a mission to Dalmatia $\left(2 \mathrm{Ti}^{\mathbf{1 0}}\right)$. He is a trustworthy, confidential delegate, walking in the Apostle's steps, walking in the same spirit (2 $\left.\mathrm{Co}_{1}{ }^{18}\right)$, his "brother" $\left(2 \mathrm{Co}_{2}{ }^{13}\right)$, his fellowworker and sharer of his toils $\left(8^{23}\right)$. So here he is a "genuine son, sharing the same faith $\left(1^{4}\right)$; his life is to be a pattern to younger men $\left(2^{7}\right)$; but there is less of personal guidance and exhortation than there was to the younger and more timid Timothy. His name does not occur in the Acts, but two interesting suggestions have been made: (i) that he was a relative (Ramsay, St. Paul the Traveller and Roman Citizen, pp. 284-86, 390), or even the brother (Souter, Expository Times, March 1907 , cf. 2 Co $8^{17.18} \mathrm{I}^{18}$ ) of St. Luke; (ii) that he was the author of the "we" sections in the Acts. Either would account for the absence of any mention of him in Acts; but both are precarious. Later ecclesiastical tradition spoke of him as Bishop of Crete (Euseb. H.E. iii. 4), and as living to a very old age; and there was an Acts of Titus, which is no longer extant (cf. Lipsius, Die Apokr. Apostelgeschichte, iii. pp. 401-06), and a panegyric on him is found in the works of Andrew of Crete (Migne, Patrol. Gr., vol. 97). $\mathrm{He}$ is commemorated on Jan. 4 in the Latin Church, on Aug. 25 in the Greek, Syriac, and Maronite Churches (Acta Sanctorum, i. pp. 163, 164; Nilles, Kalendarium Manuale). 


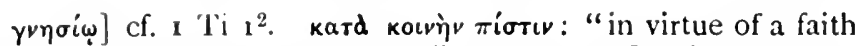
which is common to you, to me"-to you a Gentile as much as to me a Jew-but also with the wider suggestion, "a faith common to all Christians": cf. Jude ${ }^{3}$; but not so definite as "secundam fidem catholicam" (Holtzmann). Cf. Acta Carpt

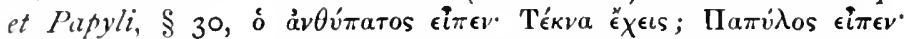

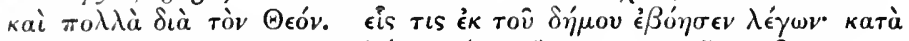

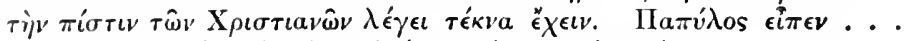

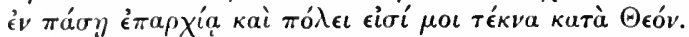

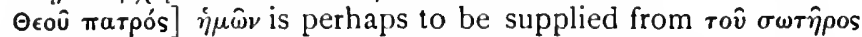

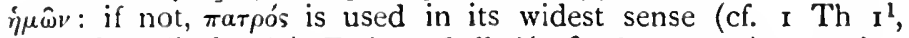

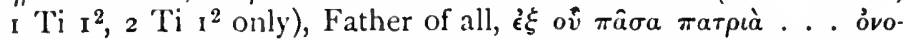

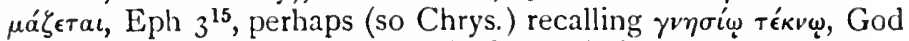
the source of all fatherhood, and of my relation to you my son.

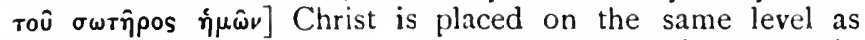
God ${ }^{3}$; the phrase anticipates the stress on salvation from sin in $2^{11 \cdot 14} 3^{4-7}$.

5-9. Paraphrase. Be sure to carry out the purpose for which I left you behind in Crete: there was much left by me incomplete; you were to complete it by appointing a body of elders in each city. I gave you general instructions, but the important point in the choice of them is the character they bear in their own homes. One whom you appoint must not be liable to have any charge brought against him, he must be the husband of one wife, his children must be loyal and trustworthy-not liable to be accused of wasteful extravagance or disorderly life. For it will never do for the presiding officer of a church to be liable to have any charge brought against him ; for it is God's own family that he has to control. So he must not be selfwilled, not hot-tempered, not violent in speech, nor given to striking others, nor willing to make money in unworthy ways: he must be ready to welcome Christian passers-by, to give a welcome to every one and everything that is good ; self-controlled, just to others, holy in character, having himself well in hand, holding firmly a preaching that is loyal to our doctrine: for he has a twofold duty-both to stir up the faithful by the sound teaching that he gives and to answer those who oppose it.

Cf. I $\mathrm{Ti} 3^{\mathbf{1 . 7}}$ and the notes there. The main qualifications for the presbyters are the same in both places, but I Ti implies a community of longer standing and completer organization-

$(a)$ in insisting more upon good testimony to character from those without,

(b) in excluding recently-converted Christians ( $\mu \grave{\eta} v \epsilon o \dot{\phi} \phi v \tau o v)$,

(c) in laying down rules for deacons and deaconesses as well. 


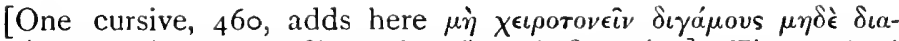

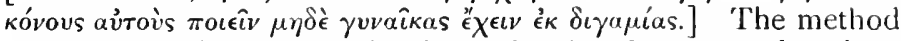
of ordination is left undefined. A free hand seems to be given

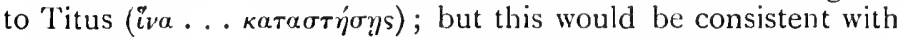
a previous choice by the community (cf. Acts $6^{5}$, I $\mathrm{Ti} \mathbf{I}^{20}$ note). The duties are also undefined, but there are implied discipline over the members of the community, teaching, perhaps control

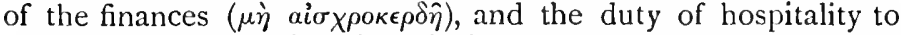
strangers. The qualifications insisted upon are moral: they are such as have been tested in the family life of the candidate before his appointment, and therefore show, even in points like "the husband of one wife," the standard expected in a good

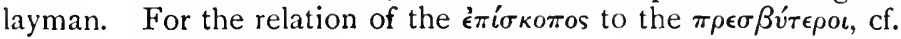
Introd., p. xx; and for the whole section, Hort, The Christian Ecclesia, pp. 190-92.

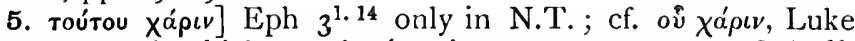
$7^{47}$ and the adverbial use of $\chi^{\alpha} \rho \iota \nu$ is very common, e.g., Gal $3^{19}$, I $\mathrm{Jn} 3^{12}$.

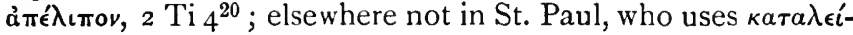
$\pi \epsilon \iota v$ ( $\mathrm{Th} 3^{1}$ only). Both words were in common usage. $\dot{\alpha} \pi o \lambda$. perhaps suggests more than $\kappa a \tau a \lambda$. the thought of intentionI purposely told you off for this work, and left you behind for it.

$7 \dot{a} \lambda \epsilon^{i}$ movтa] in this neuter sense, $3^{13}$, Luke $18^{22}$ only in N.T., but common both in prose and poetry; cf. 'iv' $\dot{\epsilon} \pi \alpha \nu \rho \rho \theta \dot{\omega} \sigma \eta \tau a \iota \tau \grave{\alpha}$ $\epsilon \lambda \lambda \epsilon i ́ \pi o v \tau \alpha$, Plut. X. Or. Vita, p. 844 E (Wetstein).

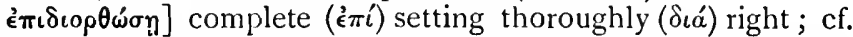

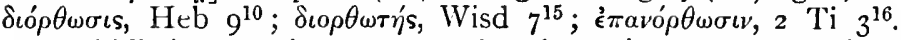
The middle is not quite so personal as the active "see that things are got right under your guidance."

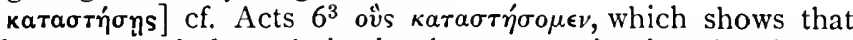
it does not exclude a choice by the community, but the change from the middle $\epsilon \dot{\pi} \iota \delta\llcorner\rho \theta \dot{\omega} \sigma \eta$ perhaps points to the separate action of Titus.

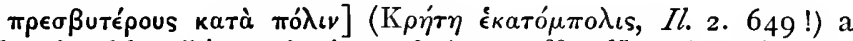
body of "elders" in each city; cf. Acts $\mathrm{I}_{4}{ }^{23}{ }_{20}{ }^{17}$, and I Ti 4 " $\pi \rho \epsilon \sigma \beta v \tau \epsilon^{\rho} \iota \mathrm{v}$, which 'Theophylact substitutes here both in text and commentary.

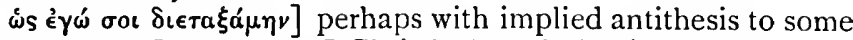
opponents at Crete: "as $I$, Christ's Apostle (cf. ò '̇ं $\iota \sigma \tau \epsilon \hat{\theta} \theta \eta \nu$ '́ $\gamma \omega$, $\mathrm{I}^{3}$ ), laid down to carry out my own ideal (niddle; cf. I Co $7^{17}$

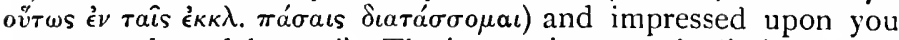
my son and my delegate." The instructions may be limited to the following qualifications for the ministry: but more probably they were wider, and included rules for the method of appointment and the duties of the presbyters.

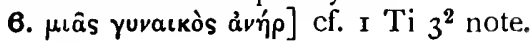


$\pi \iota \sigma \tau \alpha ́$ ] perhaps "believing," "Christian," "non ad idolorum culturam proruentes," Thd. ; cf. I $\mathrm{Ti}_{4}{ }^{\mathrm{s}} 5^{16} 6^{2}$, Concil. Carthag. iii. Canon xviii. "ut episcopi et presbyterı et diaconi non ordinentur priusquam omnes qui sunt in domo eorum Christianos catholicos fecerint." More probably, as suiting the following

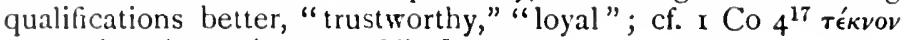

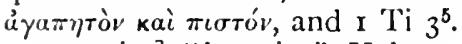

äwrías] "luxurix," Vulg.; "lasciviæ," Thd.-Mops. The

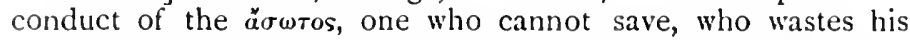
money, often with the implication of wasting it on his pleasures,

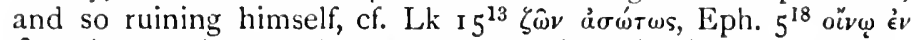

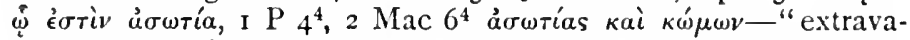
gance," "prodigality," almost "profligacy." Aristotle (Nic. Eth.

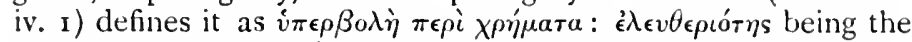

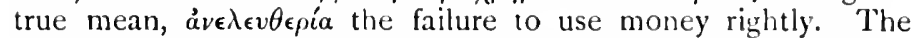

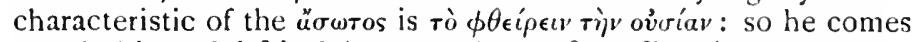

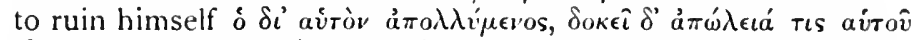

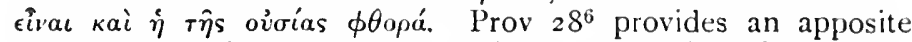

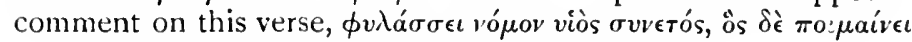

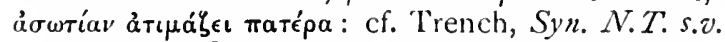

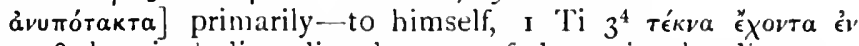

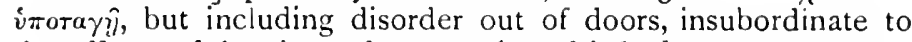

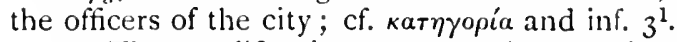

7. The qualifications are partly negative, partly positive. (i.) Negative: qualities which would prevent his successful government of the community or discredit it.

aủ $\theta \dot{\alpha} \delta \eta]$ self-willed, obstinate in his own opinion, arrogant, refusing to listen to others, "superbum," Vulg.; "audacem," Thd.; "stubborn," Tynd.; "frowarde," Geneva. In Aristotle

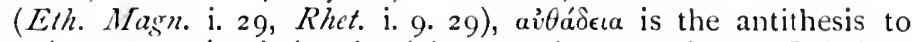

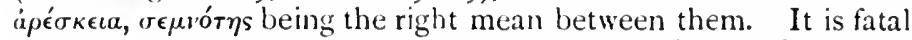

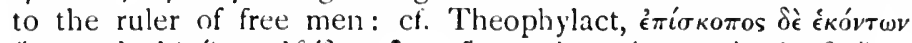

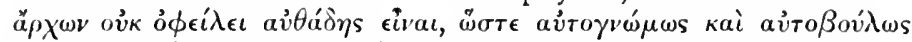

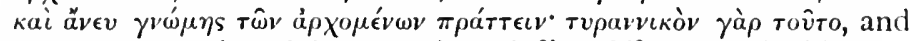

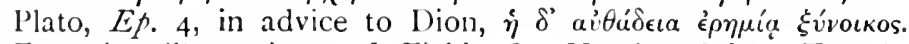
For other illustrations, cf. Field, Ot. Norvic. ad loc.; Trench, N.T. Sy'n., M.M. s.v.

mápowvov] perhaps quite literally_ "not given to much wine"; cf. $2^{3}, 1$ 'Ti $3^{8}$; "vinolentum," Vulg. : but this is not necessarily implied: perhaps only "blustering," "abusive," like a man who has been drinking; cf. Joseph. Ant. iv. 6. Io (Holtzmann), where $\pi$ apou $\epsilon \hat{i v}$ is used of the Israelite who married a Midianitish woman, as the antithesis to $\sigma \omega \phi \rho v^{\prime} \epsilon \hat{\imath},=$ " to act outrageously";

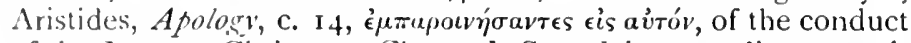
of the Jews to Christ: so Chrys. de Sacerd. iv. I applies mapotvia to the conduct of the sons of Eli. 
$\left.\pi \lambda \eta^{\prime} \kappa \tau \eta \nu\right]$ quite literally, not hasty to strike an opponent; cf.

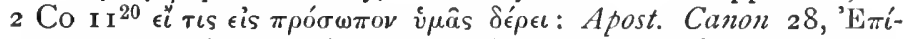

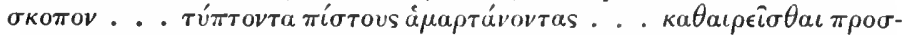

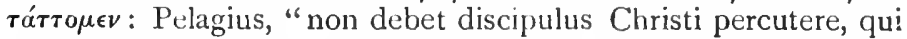
percussus est et non repercussit." But the Greek commentators

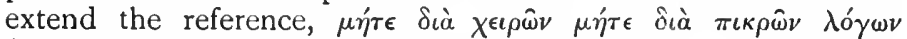

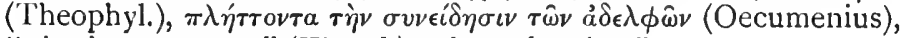
"cito increpantem "(Theod.), "brow-beating."

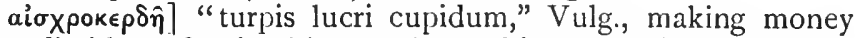
discreditably: adapting his teaching to his hearers in the hope of money from them (cf. ${ }^{11}, \mathrm{I} \mathrm{Ti} 6^{5}, \mathrm{I} \mathrm{P}^{2}$ ); or appropriating to his own use the gifts of the faithful (cf. 2 Co I $2^{16-18}$, Jn $12^{6}$ ); or perhaps engaging in discreditable trades (cf. $3^{8}$ note). Contrast St. Paul's example, Acts 2033. 34. For the Cretan love of money, cf. supra, p. I 22.

8. (ii) Positive: mainly the central Christian Virtues, and those which will fit him for ruling and teaching: there is more stress laid here than in I Ti on the teaching test.

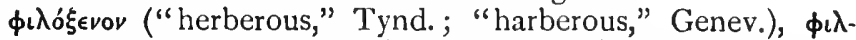

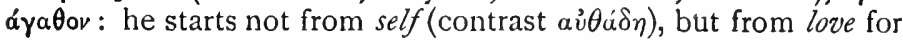
others, cf. $2 \mathrm{Ti} 3^{2}$ note; ready to welcome Christian passers-by (cf. $3^{13}$, I Ti $3^{2}$ note); ready to welcome all good men, or prob. ably "goodness wherever he sees it," cf. Wisd $7^{22}$ "ै $\sigma \tau \iota \nu$ ' $\nu$ "

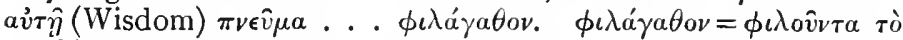

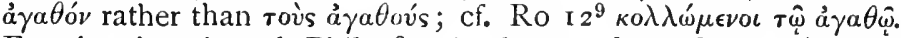
For the thought, cf. Phil $4^{8}$; "a lover of goodness" (Tynd., Coverdale).

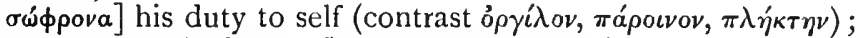

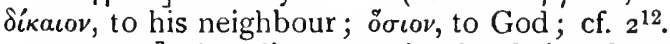

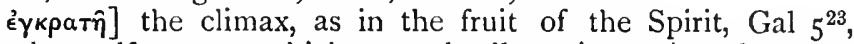
complete self-mastery, which controls all passionate impulses, and keeps the will loyal to the will of God; cf. Additional Note, p. 148.

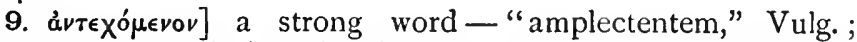
"tenacem sermonis," Ambrosiaster; "utroque brachio amplexi et mordicus tenentes," Calvin; "holding firmly to"-both for his

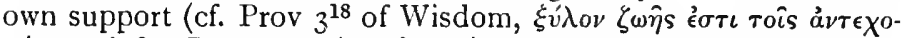

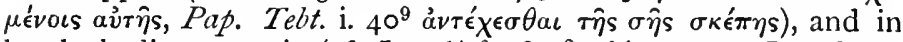
loyal obedience to it (cf. Is $5^{4.6} \tau \hat{\eta} s \delta \iota a \theta \dot{\eta} \kappa \eta s \mu o v$ : Jer $2^{8}$ tov

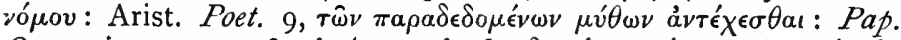

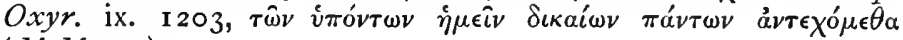
(M.M. s.v.).

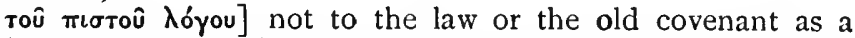
Jewish Rabbi would (cf. last note), much less to commandments of men $\left({ }^{14}\right)$, but to the trustworthy ("unde admonitio et elenchus robur accipit," Bengel) message (cf. "), which corresponds with 
the true teaching - the teaching of the Apostle himself (cf. Ro $6^{17}$

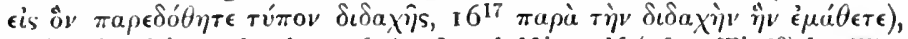
which is ultimately that of the Lord Himself (cf. I 'Ti $\left.6^{3}\right){ }^{1}$ 'The phrase suggests a stereotyped outline of doctrine, either oral or written, such as is quoted in 1 Co $15^{3 \mathrm{fff}}$.

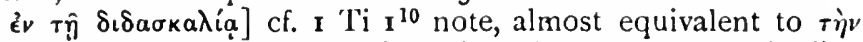
$\delta\left\llcorner\delta a \chi \eta^{\prime}\right.$ of "the body of doctrine," but thought of as embodied

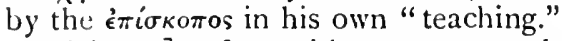

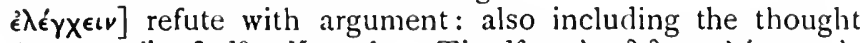

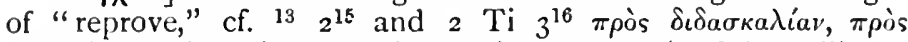
$\dot{\epsilon} \lambda \epsilon \gamma \mu o ́ v$. Origen in a very interesting chapter (c. Celsum, iii. 48, cf. vi. 7) quotes this verse in answer to the taunt of Celsus that Christianity only appealed to the uneducated.

10-16. Necessity for such qualifications: the character of the false teachers at Crete and the substance of their teaching.

Paraphrase. They will need this qualification, for there are many at Crete who are unwilling to submit to any control, teachers of worthless doctrine, clever enough to impose upon the minds of others-this is especially true of those of them who have been Jews-and all these must have their mouths stopped; forasmuch as they upset whole households, teaching things which they know they have no right to teach, merely to make gains of which they ought to be ashamed. It was one of their own islanders, one whom they themselves regard as a prophet, who said :

"Cretans are always liars, very Minotaurs, gluttonous, idlers."

This testimony is true. Wherefore rebuke them sharply, that they may be sound in their faith, and not devote themselves to Jewish legends and commandments, which are only commandments of men, aye, and of men who are turning their backs upon the truth. It is true that "All things are pure to the pureminded "; but to those who have been defiled and have no true faith, nothing is pure; nay, for them both mind and conscience have been defiled. And that is the case with them: God, indeed, they acknowledge in their creed, but in their lives they belie such knowledge, being abominable, and disobedient, and with a view to every good work, unable to stand the test.

Note-These teachers are not heathen; they are professing Christians $\left({ }^{16}\right)$, mainly but not wholly Jewish Christians $\left({ }^{10}\right)$, who pander in their teaching to curiosity and dwell upon Jewish legends of the patriarchs, and add to the Christian life a number of external duties which can claim no divine authority, and which

${ }^{1}$ For the interpretation of the phrase as a reference to the Personal Logos, cf. $3^{8}$ note. 
deal with the distinction between things clean and unclean $\left({ }^{15}\right)$, and spring out of the Jeu ish law $\left(3^{9}\right)$. There is no reference to the enforcement of circumcision; so that they do not correspond to the Pharisaic Jewish Christians denounced in Gal., but more to the opponents at Colossæ, Jews of the dispersion trying to represent certain sides of the Jewish life as a higher philosophy (cf. Hort, Judaistic Christianity, pp. 116-46). Such Jewish teaching would find natural support in incipient tendencies to Gnosticism, with its belief in the evil of matter, and that may be subordinately alluded to in $\mathbf{1 5 . 1 6}$.

The writer deals with this teaching in two ways:(I) it is sharply denounced as profitless for all moral purpose; it does not raise the moral life or fit men for service; (2) appeal is made to great Christian principles. True purity is purity of heart: true faith must issue in good works.

10. $\gamma$ áp] gives primarily the reason for the last qualification (cf. ${ }^{\epsilon} \lambda \epsilon^{\prime} \gamma \chi \chi^{\epsilon}{ }^{\prime}{ }^{9}, "{ }^{\prime \prime} \lambda \epsilon \gamma \chi^{\epsilon}{ }^{13}$ ), but also for the whole section $\left({ }^{5-9}\right)$.

ávuтótakтor] $\mathrm{cf}^{6}{ }^{6}$ (which was leading up to this) and $3^{1}$ note.

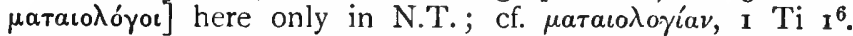
$\mu$ átalos was the favourite Jewish term of scorn for heathen idols and worship: this thought may be present here. Their teaching, so far from being on a higher level, is as worthless as that of heathenism; cf. $\beta \delta \in \lambda u \kappa \tau o i{ }^{16}$.

$\left.\phi \rho \in v a \pi a ́ \tau \alpha_{\imath}\right]$ here only in N.T., but $\phi \rho \epsilon v a \pi a \tau \hat{\alpha} v$, Gal $6^{8}$. Scarcely (as Lightfoot, ad loc.) $=\phi \rho \epsilon v i$ a $\pi a \tau \hat{a} v$, to deceive by

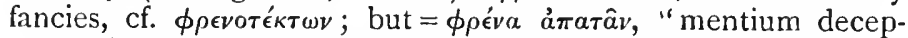

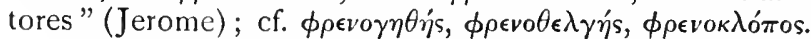

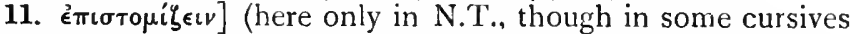
of Lk I I ${ }^{53}$ ), perhaps anticipating кака̀ $\theta \eta_{p \iota \alpha}{ }^{12}$ : either "to bridle," "to guide aright," "refrenari" (Jerome), cf. Jas $3^{3}$; or more probably " to muzzle, to silence" : "redargui" (Vulg.), "silentium indici" (Jerome). This is more analogous to its classical usage; cf. illustrations in Wetstein and in M.M. s.v.

ò $\lambda$ ous oikous] Where order and discipline need such careful guidance; cf. ${ }^{6} 2^{1-10}$.

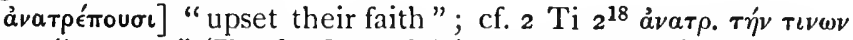
$\pi i \sigma \tau \iota v$, "pervert" (Tynd., Coverdale), or "upset their peace and harmony," "subvert," A.V.; contrast the teaching of $2^{1-10}$.

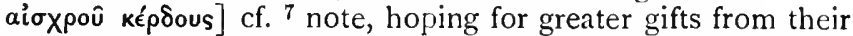
hearers; cf. I Ti $5^{17,18} 6^{5}, 2$ Co $12^{14-18}$. For this tendency at

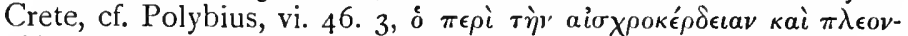

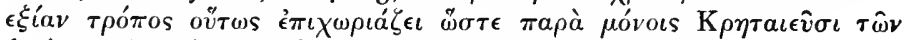

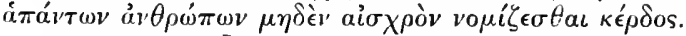

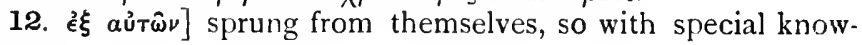
ledge.

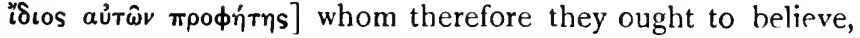


and whom I may quote without offence: Epimenides, whom they regarded not merely as a poet but as a prophet, a great

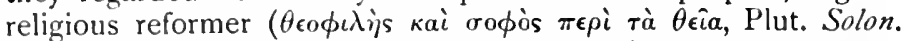
12) and predicter, who had predicted the failure of the Persian invasion of Greece ten years before it took place (Plato, Lawos, i. 642 D), and whom we may still regard as a prophet, his words in this saying being true still; cf. the treatment of the words of Caiaphas $\left(\mathrm{J}_{n} \mathbf{I}^{51}\right)$, of Balaam's ass $\left({ }_{2} \mathrm{P}_{2^{16}}\right)$. Similarly Irenæus (iv. 33. 3), apparently borrowing the phrase from here: "Accusabit autem eos Homerus proprius ipsorum propheta" (Wohlenberg).

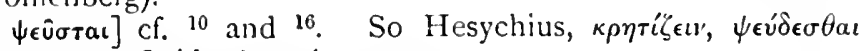
каї ảmaтâv: Ovid, Ars. Am. 1297 :

"Nota cano: non hoc, quie centum sustinet urbes,
Quamvis sit mendax, Creta negare potest,"

and other interesting illustrations in Wetstein.

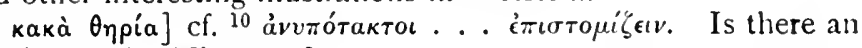
allusion to the Minotaur?

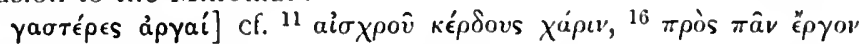

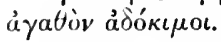

Note.-I. The line was attributed to Epimenides (of Crete, 600-500 B c.) doubtless in pre-Christian times. It is quoted as from him by Clem. Alex. (Strom. 1. xiv. 59), by Jerome (here) as from a poem entitled X $\rho \eta \sigma \mu o i$, Oracula, and by Isho'dad, a Syrian conmentator (c. A.D. 850), as from the Minos (cf. Rendel Harris, Expositor, 1906, p. 305 ; 1907, p. 332 ; 1912, p. 348). But the attribution is very doubtful, as the dialect is Attic and not Cretan (cf. Moulton, N.T. Gr. i. p. 233 n.). It was probably earlier than Callimachus (A.D. 300-240), who quotes the first half of it in his hymn to Zeus :

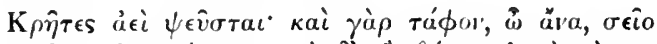

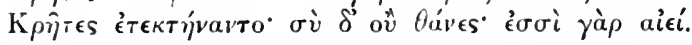

And it was probably the legend that the tomb of Zeus was to be found in Crete that gave rise to the charge of lying as characteristic of Crete. It is also possible, as Rendel Harris also suggests, that the last half of the verse is abuse of the animal sacrifices and the feeding on them in the worship of the Cretan Zeus. His further suggestion, that the words in Acts $17^{28}$, "For in him we live, and move, and have our being," are a quotation from the same poem of Epimenides, would give an interesting link between our writer and St. Paul, but can scarcely be maintained; they are too mystical for so early a date (cf. J. U. l'owell, Classical Revieze', Aug.-Sept., 1916).

2. For an interesting account of the use of classical literature 
in the early Church, see Plummer, Expositor's Bible, c. xx. Clem. Alex., in quoting this passage (l.c.), adds: "you see how Paul assigns even to the prophets of the Greeks an element of the truth, and is not ashamed to use Greek poems for edification and rebuke": but when heathen critics urged that the quotation virtually implied St. Paul's belief in the real and immortal existence of Zeus, the Fathers take pains to refute the inference. So Chrys. Theod. Thdt. Jerome, ad loc.

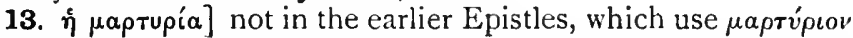
(four times): perhaps slightly different, "witnessing," rather than "witness." For similar severity, cf. Ro $16^{18}$, Phil $3^{19}$.

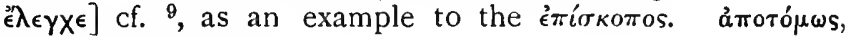
2 Co $13^{10}$, only in N.T.

$\delta \iota^{\prime}$ îv aitíav] Lk 87 $^{47}$, Acts $22^{24}$, Heb $2^{11}, 2 \mathrm{Ti}^{6.12}$, only in N.T., not in the earlier Epistles: perhaps a Latinism=quamo-

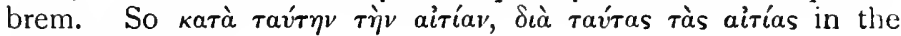
papyri, $M . M$. s.v.

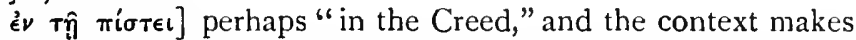
this almost certain; but, possibly, "in their faith, their loyalty to Christ": cf. $2^{2}$.

14-16. Cf. $\mathrm{Ro}_{1} 4^{13-23}, \mathrm{Col}_{2}{ }^{16-23}$, I $\mathrm{Ti}^{4-5}$ and notes there,

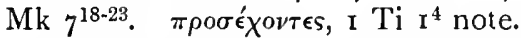

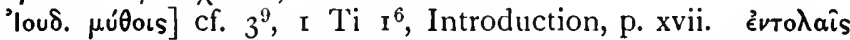
ả $\nu \theta \rho \omega ́ \pi \omega \nu$ (contrast $\epsilon^{\prime} v \tau o \lambda \hat{\omega} \nu$ $\Theta \epsilon \hat{v}$, I Co $7^{19}$ ), a reminiscence of

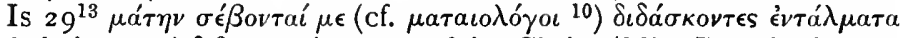

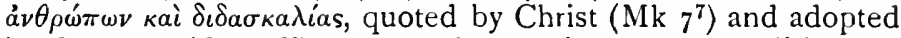
by St. Paul ( $\mathrm{Col}_{2}{ }^{22}$ ). The reference is to the "traditions of the elders," and will include interpretations of the law of clean and unclean meats and ceremonial washings, $M k 7^{2-4}$. These have no authority, as only the interpretations of men, and of men who are now turning away from (cf. Acts $13^{46}$ ) the truth "as it is in Jesus" (Eph $\left.{ }^{21}\right)$.

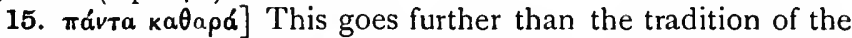
elders; it abolishes the Mosaic law, which had served the purpose of separating the Jews from the heathen world.

rois katapois] those who are pure-not, as the false teachers would say, by ceremonial washings, but by purity of heart. Cf.

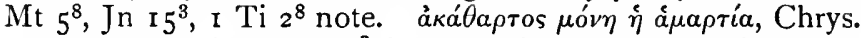

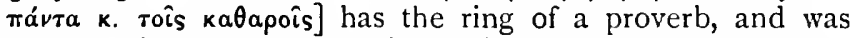
perhaps a saying of the Lord Himself (so von Soden); cf. Lk I $I^{41}$

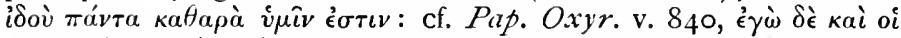

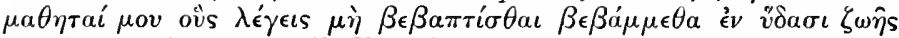

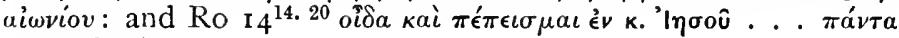
$\mu \grave{v} v \kappa \alpha \theta \alpha \rho \alpha$.

The thought, especially on the negative side, that the impure heart makes all things impure, was found in the prophets; 
cf. Hag $2^{10-14}$, and was becoming a common-place of pagan philosophers, both Epicurean and Stoic; cf. Lucr. vi. I 7-34; Hor. Ep. i. 2. 54, "Sincerum est nisi vas, quodcunque infundis acescit." Seneca, de Benefic. v. I2, "quemadmodum stomachus morbo vitiatus ... quoscunque accepit cibos mutat, ita animus crecus quicquid illi commiseris, id onus suum et perniciem . . . facit. Nihil potest ad malos pervenire quod prodest, immo nihil quod non noceat ; quæcunque enim illis contigerunt in naturam suam vertunt, et ... profutura, si melioribus darentur, illis pestifera sunt," and Philo, de Legg. Spec. iii. 209, p. 334 M,

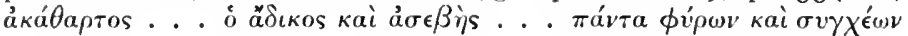

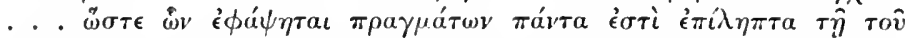

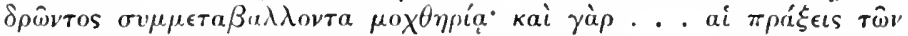

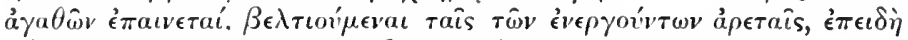

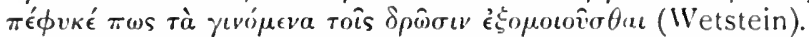

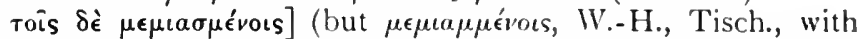
^ A C D* L ; cf. Blass, Gr. N.T., $\left.\$ 6_{3}\right)$, cf. Hag $2^{13}$ éàv å $\psi \eta \tau a \iota$

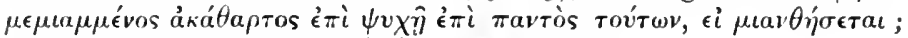

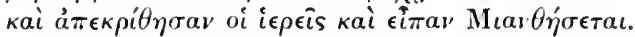

anioroเs] This would apply (a) to the weak Jewsh Christian,

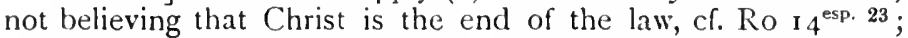

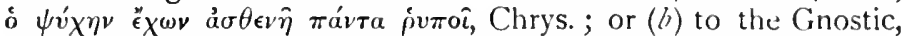
without faith in God's creation of matter, cf. I Ti $4^{1-5}$; but here the reference is only to the former.

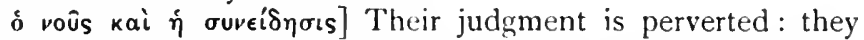
will call evil good and good evil (cf. I $\mathrm{Ti}^{5}, 2 \mathrm{Ti} 3^{8}$ ); their conscience is callous, not telling them when they have done wrong (cf. I $\mathrm{Ti}_{4}{ }^{1}$ ), nor condenıning them when they have done it.

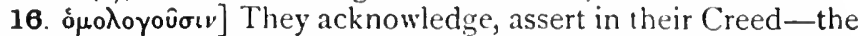
word does not imply boastful profession-that they know God, but in practice belie such knowledge; cf. Jas $2^{14-26}$, I Jn $2^{4}$.

apvoûvтac] not in the earlier, but frequent in the Past. Epistles; cf. $2^{12}, \mathrm{I}^{\mathrm{Ti}} 5^{8}, 2 \mathrm{Ti} 2^{12.13} 3^{5}$.

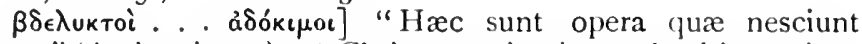
Deum" (Ambrosiaster). "Christus sapientia est, justitia, veritas, sanctitas, fortitudo. Negatur per insipientiam sapientia, per iniquitatem justitia, per turpitudinem sanctitas, per imbecillitatem fortitudo, et quotiescunque vincimur vitiis et peccatis, toties Deum negamus" (Jerome).

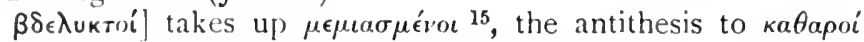

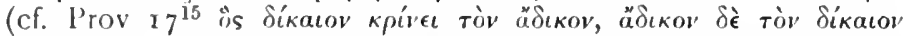

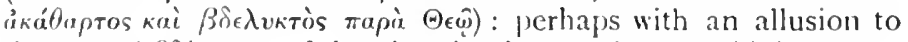
the use of $\beta \delta \delta^{\prime} \lambda v \gamma \mu \alpha$ of the abominations of heathen idolatry; $\mathrm{cf}$. matacodógoc 10 note.

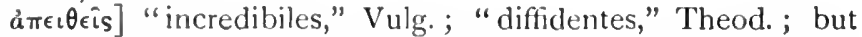
better, "inobedientes," Jer. Ambrosiaster. It takes up ämíoroıs, 
but interprets it in the sphere of action; cf. ảvvто́тактое ${ }^{10}$, and contrast $3^{1-3}$.

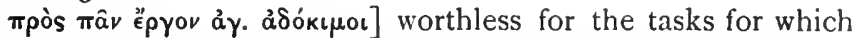
they ought to be ready $\left(3^{1}\right)$ : much more for the excellence for which God's peculiar people are eager $\left(2^{13}\right)$. The whole of $2^{1-13}$ is a contrast to this phrase.

II. 1-15. Paraphrase. But your language must be very different : you must lay stress on character, on that character which is consistent with the sound teaching, and that with regard to every member of the Christian family. Elder men you must train to be sober-minded, dignified, self-controlled, sound in their faith in God, in their love for their fellow-men, in their power of enduring persecution. Elder women similarly, to be reverent in staid demeanour, not given to gossip and scandal, not the slaves of drink, teachers of all that is excellent; for their aim should be to discipline and train the younger women to be lovers of their husbands, lovers of their children, to be selfcontrolled, chaste, workers at home, kindly to their servants, in willing obedience to their husbands : this is important' in order that the truth of God may not be evil spoken of. Younger men, too, exhort to be self-controlled; for them you yourself must be the model of what excellent character should be. When you teach, your motives sincere, your manner such as to inspire respect, your message sound and not open to criticism. This, too, is important in order that any opponent of Christianity may be put to shame, when he can find nothing evil to allege against us. Slaves, too, must be trained to be obedient to their masters, eager to please them in every way, not answering back, not pilfering, nay, showing glad whole-hearted fidelity. This, too, is most important, because by so doing they may make the teaching about God our Saviour more attractive, more likely to win their masters to it.

And such a character is possible, for the grace of God when it broke upon the world, like light dawning upon darkness, brought with it salvation for every race and class of men, and it came as a school of character training us to renounce impiety and mere worldly impulses and to live a life of self-control, of just treatment of our fellows, of piety to Godward, in this present age, while we still look forward to a better future, to the blessed hope and fresh light yet to break upon us from the glory of Him who is at once the High God in heaven and our Saviour upon earth, Jesus Christ, who gave His life unto the death on our behalf-for this very purpose that $\mathrm{He}$ might rescue us from all disobedience to law, and purify for His own service a people of His own choice, enthusiastic for all ideal works.

This is what you have to teach: aye, plead with them to rise 
to it; if need be, rebuke with all authority any who oppose. I cet no one ignore your authority.

Note.-I. The whole chapter is full of reminiscences of c. I. litus is to be in his teaching a model for the presbyters, to show them how to exhort and how to rebuke (cf. $2^{1.15}$ with ${ }^{9}{ }^{9}$ ). He is also to be a contrast to the false teachers: his teaching is to be sound, sincere, not able to be silenced (cf. $2^{7}$ with ${ }^{10}$ ): it is not to be aimless, but at all points to build up character (cf. $2^{1}$ with ${ }^{10}, 2^{14}$ with $\left.{ }^{16}\right)$ : it is not to upset families, but to build up a true family life on the basis of a willing subordination (cf. $2^{5.9}$ with I ${ }^{10.11}$ ). The "evil beasts and idle bellies" are to be disciplined into self-control (cf. $\sigma \omega \dot{\phi} \rho \omega v, 2^{2.4 .5 .6 .12}$, with $\mathrm{I}^{12}$ ): instead of attending to Jewish myths and ceremonial purifications, the Christians are to realize that they are now God's peculiar people, purified with a spiritual cleansing (cf. $2^{14}$ with $\mathrm{I}^{14.15}$ ): instead of being useless for every good work, they are to be eager to stand out before the heathen world as models of excellence (cf. $2^{14}$ with ${ }^{16}$ ).

2. 'The whole illustrates the importance attached to building up the conception of a high family life (cf. Ramsay, St. Paul, the Traveller and Roman Citizen, c. vi.), and it should be compared with $\mathrm{Col} 3^{18}-4^{1}$ (where St. Paul for the first time regulates the duties of the members of a family), Eph $5^{22}-6^{9}$ (where he treats the family as a training ground for the sense of true membership in the church), I Ti $5^{1}-6^{2}$ (where he treats of Timothy's attitude to the different classes in the church), and also $\mathrm{I}^{\mathrm{P}_{2}{ }^{18}-3^{7}}$ where, as here, the importance of the Christian's life at home is emphasized because of its effect upon the heathen world outside: but here the argument is scarcely so strong as there; here, it is mainly to avoid disparagement by the heathen, cf. $2^{5.8 .10}$; there, it is rather to win the heathen to salvation, $\mathrm{I} \mathrm{P}_{2}^{12} 3^{1}$. In no case is the similarity sufficient to suggest any literary dependence of one writer upon the other. Cf. also Clem. Rom. c. xxi.; Ign. ad Polyc. c. iv.

3. Notice the strong sense of divine and human purpose throughout the section (iva six times). It was the Divine purpose in the Incarnation that man should live a moral and religious

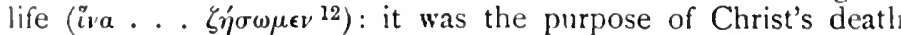
that we should be free from the power of sin and eager for excellence of life ( with this purpose; the elder women are to aim at training the younger ( $\left.{ }^{*} \alpha \sigma \omega \phi p o v i \xi \omega \sigma \iota^{4}\right)$ : the younger women, at keeping

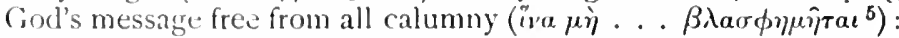
more strongly still, Titus and the younger men can act so as to

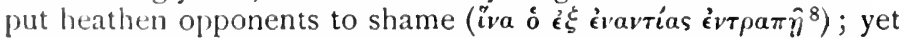
more strongly still, even slaves can make it their aim to add 
fresh lustre to the doctrine and make it attractive to the heathen

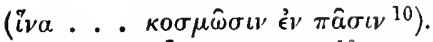

1. $\sigma \dot{v} \delta \dot{\epsilon}]$ contrast $2^{10}$. $\tau \hat{\eta} \dot{u} \gamma$. $\delta\llcorner\delta \alpha \sigma k$., which is to be the standard for the presbyters, $I^{9}$.

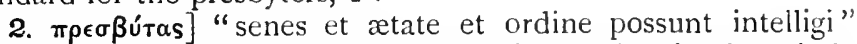
(Pelagius and Oecumenius); but there is nothing in the whole context to suggest official position of any kind, either in the other classes referred to or in the qualities required.

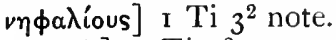

$\sigma \in \mu \nu$ oús] I Ti $2^{2}$ note. $\epsilon$ ival, possibly the imperatival infinitive, cf. Phil $3^{16}$, Ro ${ }^{15}{ }^{15}$ (Moulton, N.T. Gr. i. p. I 79); but

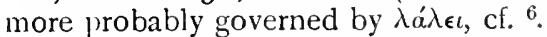

oúфpovas] "castos," "pudicos," perhaps also wise in counsel "prudentes," Clarom.; cf. Add. Note, p. i 48.

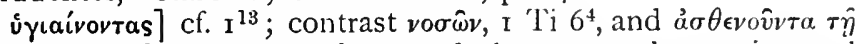
$\pi i \sigma \tau \epsilon \iota, \mathrm{Ro} 14^{1}$ : they must be sound, there must be no internal weakness in any part of the Christian life; their faith in God must not be half-hearted, must have no alloy of false human teaching $\left(\mathrm{I}^{14}\right)$; their love must not wax cold in the presence of the lawlessness around them (Mt $24^{12}$ ), it must not be unbalanced; their power of endurance must be able to hold out against the provocations and persecutions of the world around them (cf. 5.7 $3^{2}$ ). Each quality must be able to stand a strain without snapping. The thought of "soundness" is most applicable to "faith," but it perhaps also suggests a "sanitas caritatis" and a "sanitas patientia" (Jerome), in the sense that each quality may degenerate into weakness. "Love," which is not weak, sentimental, dangerous, cf. Orelli, Inscr. Lat. 465 I, "quæ dum nimia pia fuit, facta est impia"; "endurance," which is not fainthearted nor yet callous, obstinate, fanatical, which will not court martyrdom. Jerome, whose note is excellent, points to I Co I 3 as defining the "sanitas caritatis"; cf. Augustine's "serenitatem dilectionis" (Conf. ii. 2) ; Tyrrell, Hard Sayings, p. 295, "He came to teach our afiections a rhythm from heaven." Wordsworth's "Laodamia":

"The Gods approve

The depth and not the tumult of the soul, A fervent, not ungovernable love";

and for the combination of the three, S. T. Coleridge, "Love, Hope and Patience in Education":

"Yet haply there will come a weary day

When, overtasked at length,

Both Love and Hope beneath the load give way.

Then, with a statue's smile, a statue's strength,

Stands the mute sister Patience, nothing loth,

And, both supporting, does the work of both." 
3. $\pi \rho \epsilon \sigma \beta \dot{\tau} \tau\llcorner\delta a s]$ this again has been referred (Theod. Oecuinenius) to some prominent official position in the community ("wie es heute bei den Herrenhutern der Fall ist," Koehler), such as is found later; cf. the I Ith Laodicean Canon, $\pi \epsilon \rho \hat{\imath} \tau o \hat{v} \mu \grave{\eta}$

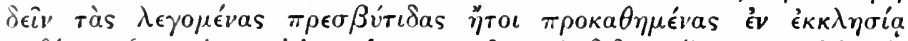

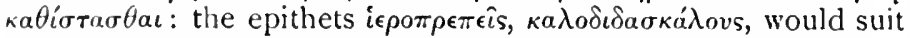
this, but the whole context is against it (cf. note on ${ }^{2}$ ).

$\kappa \alpha \tau \alpha \sigma \tau \eta \dot{\mu} \mu \tau \iota$ ] demeanour, deportment ("incessus, motus, vultus, sermo, silentium," Jerome), but with the additional thought

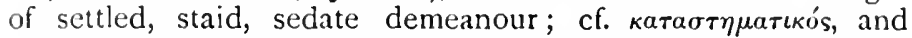

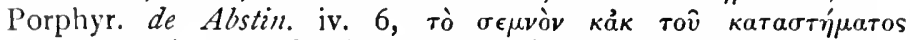

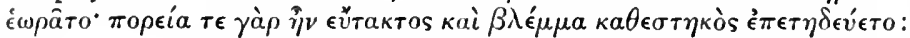

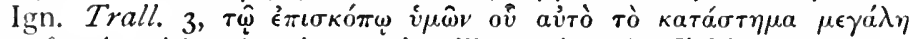

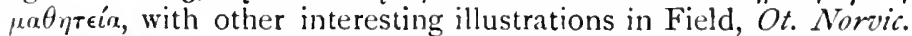

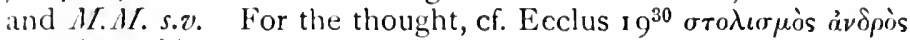

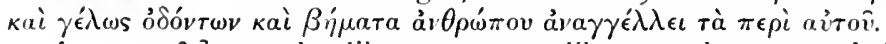

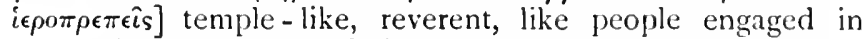

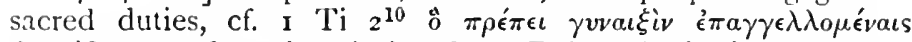

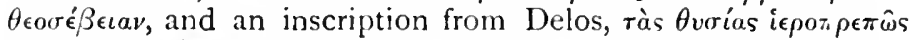

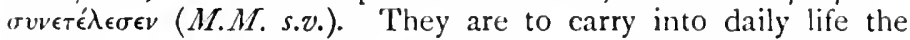
demeanour of priestesses in a temple; cf. Philo, Quod omnis

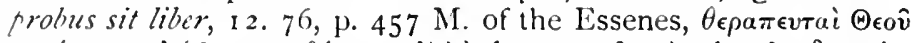

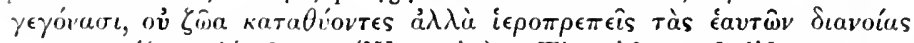

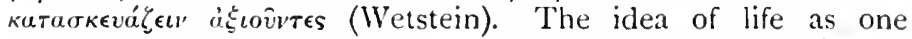
constant festival to the wise man is found in Stoic writers (Marc.

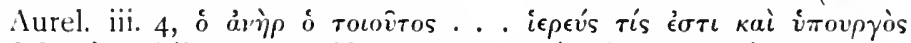

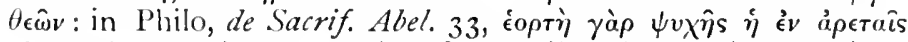

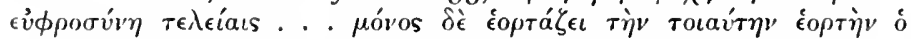
voфós, and in early Christian writers, Clem. Alex. Strom. vii. 49,

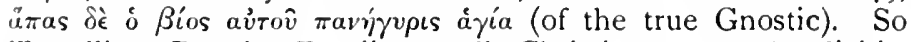
Tertullian, De cultu Fem. ii. I 2, calls Christian women "pudicitiæ sacerdotes."

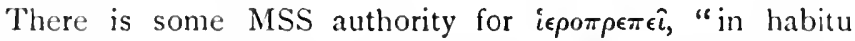
sancto," Vulg.; "in habitu decenti," Theod.-Mops., cf. I Ti $2^{9} \dot{\epsilon} v$ $\kappa a \tau \alpha \sigma \tau о \lambda \hat{\eta} \kappa о \sigma \mu \boldsymbol{i}^{\prime} \omega$ : but the following adjectives strongly support the plural here.

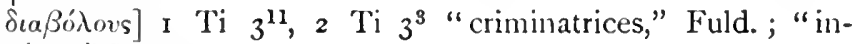
centrices," Jerome.

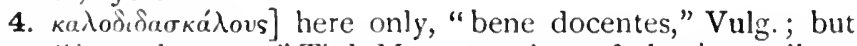
better, "bona docentes," Thd.-Mops., teachers of what is excellent.

iva $\sigma \omega \phi p o v i \zeta \omega \sigma l]$ not neuter, "that they may be self-con-

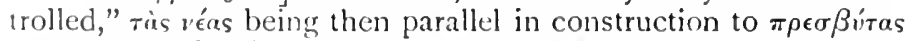
and $\pi$ etrßútious (so Calvin, Hofmann, Wohlenberg); for this is scarcely adequate as the climax of the preceding, nor sufficiently paraliel to the other final sentences with iva: but active, that they may discipline, train in $\sigma \omega$ ortonoriv $\eta$ the young women; cf. $\sigma \omega \phi \rho o v$. 


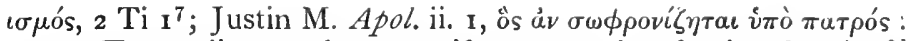
Xen. Econ. vii. I4, where a wife says to her husband $\epsilon^{\prime}$ 'òv $\delta$ '

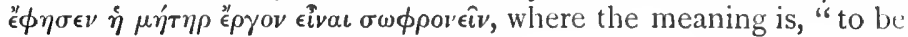
prudent in household management."

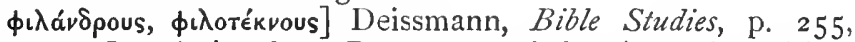
quotes an Inscription from Pergamum of the time of Hadrian,

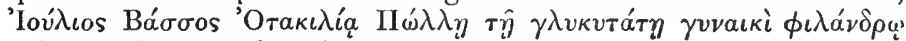

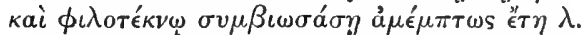

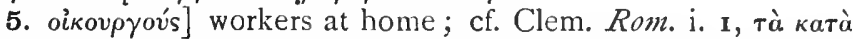

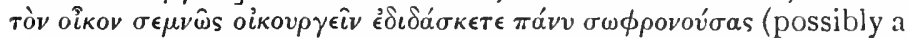
reminiscence of this passage). Orelli, Inscr. Lat. 4639, "pia, pudica, frugi, casta, domiseda": ibid. 4848 , "domum servavit, lanam fecit"; contrast I Ti $5^{13} \pi \epsilon \rho \iota \epsilon \chi^{13} \mu \epsilon v a \iota$ tàs oikías, Prov $7^{11}$ of a

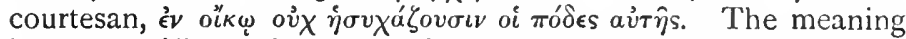
is not far different from that of the more usual oikovpov́s, "homeminders," "domus curam habentes" Vulg., "domos suas bene regentes" Theod.-Mops., which is read here in $\kappa^{c} D^{c} H \omega \Sigma$.

a $\gamma \nu$ ás] cf. the frequent appeal of the Christian Apologists to the high standard of Christian wives, e.g. Tert. Apol. 9, "diligentissima et fidelissima castitas."

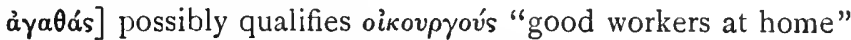
(Hofmann, Wohlenberg, Riggenbach), but more probably introduces a new feature, "kindly," i.e. mainly, "to their servants," " benignas," Vulg.; "quasi dicat, cum mansuetudine

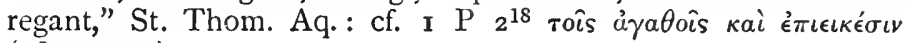
(of masters).

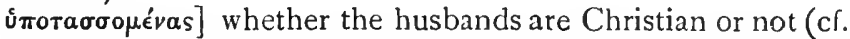
I Ti 6. 2, I Co $7^{10-16}$ ). Chrysostom and Theodoret add the later application, that they are not to leave their husbands through wishing to live a "religious" life. For the duty, cf. 1 Co $14^{34}$, Eph $5^{22}$, Col $3^{18}$. Resch, Paulinismus (T. und U., N.F. xii. p. 463) thinks that a command of the Lord (cf. I Co $14^{37}$ ) lies behind the command of the Apostle.

iva $\mu \grave{\eta} \ldots \beta \lambda \alpha \sigma \phi \eta \mu \hat{\eta} \tau a i]$ a reminiscence of Is $52^{5} \delta \imath^{\prime} \dot{v} \mu \hat{a} s$

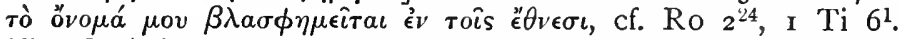
The Christians are now God's "peculiar people" $\left({ }^{14}\right)$, like the Jews in captivity, in a heathen world. They have to protect from abuse not only "the name" (rò övoua) of God, but His new

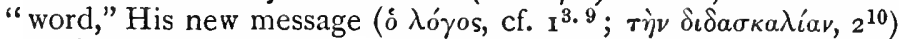
of universal salvation, ${ }^{11}$. To the Jew the profanation of God's Name was the deadliest $\sin$, even as the sanctification of the name, especially by martyrdom, was the highest duty; cf. C. G. Montefiore in Beginnings of Christianity, i. pp. 63-65.

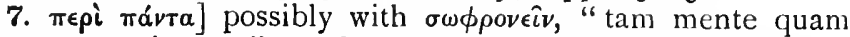
corpore ... in omnibus rebus, ne honores indebitos appetamus, ne accendamur avaritia, ne ulla passione superemur" (Jerome), 
but more prohably with $\pi \alpha \rho \epsilon$ ó $\mu \epsilon$ vos, being expanded in the following words; cf. $1 \mathrm{Tl}^{\mathrm{i}} 4^{\text {12 }}$.

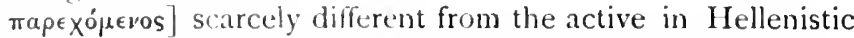
Greek, of. Col $t^{2}$; and hairly common with the reflexive pronoun in inscriptions; cf. Deissmann, B.S., p. 254; Moulton, N.T. Greek, i., pp. I 55-59.

év $\tau \hat{n} \delta\llcorner\delta a \sigma k a \lambda i a ̣]$ "in your teaching," to be joined with all

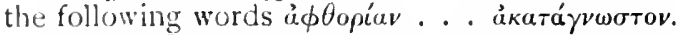

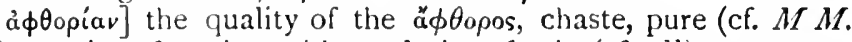
s.v.) : purity of motive, without desire of gain (cf. $\mathrm{I}^{11}$ ) or respect of persons, and purity of doctrine (cf. 2 Co $4^{2} a \dot{a} \pi \epsilon \iota \pi \dot{a} \mu \epsilon \theta a$ rà

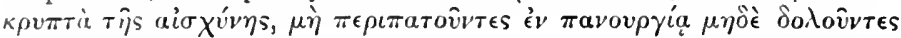
Tòv $\lambda o ́ \gamma o v)$.

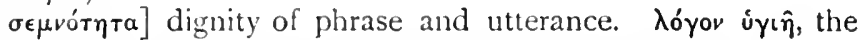

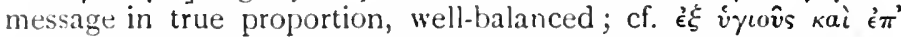

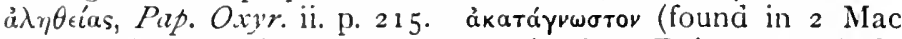
$4^{47}$ and in several contemporary epitaphs; Deissmann, B.S., p. 200), not liable to be censured, criticized, silenced; contrast ${ }^{10} 3^{11}$, Gal $2^{11}$.

8. $\left.\delta \epsilon^{\prime} \xi \epsilon^{\prime} v a v r i a s\right]$ "he that is of the contrary part"-doubtless the main thought is of pagan criticism; cf. ${ }^{5.10}, \mathrm{IP}^{2} \mathbf{2}^{12-15}$, I Ti

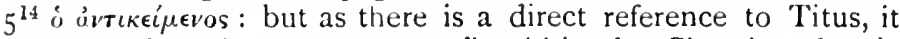
may include "the contrary part" within the Church; cf. tois

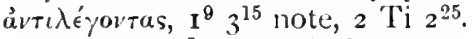

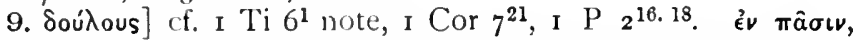

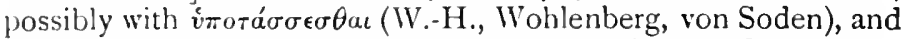
this balances best with $\dot{\epsilon} \nu \pi \hat{\alpha} \sigma \iota v$ at the end; but cf. Clem. Alex.

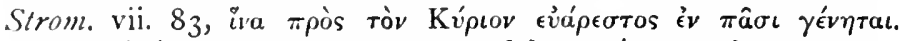
The Patristic commentators are careful to point out the necessary limitation, e.g. "quæ imperant justa," Pelagius; so Jerome, Thd.

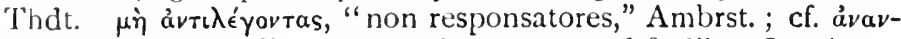

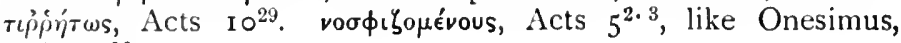
Philem ${ }^{18}$.

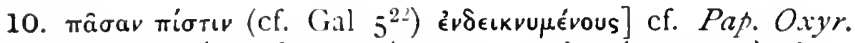

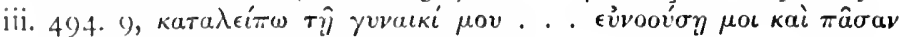

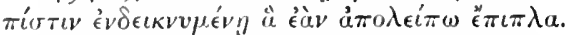

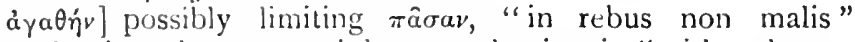
(Bengel); but almost certainly strengthening it "with a hearty

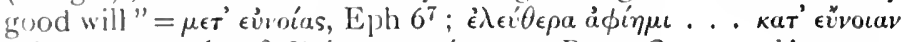

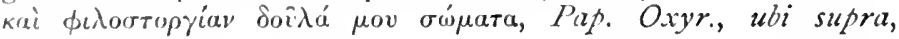
line 6

$\mathrm{W} .-\mathrm{H}$. place in the margin, as an alternative reading, $\pi \hat{\alpha} \sigma \alpha v$

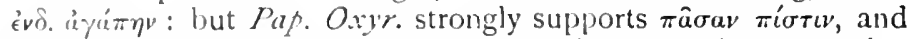
ciyámiv may have been an attempt to avoid the doubtful meaning of ayutive : cf. Introd., p. xxxviii.

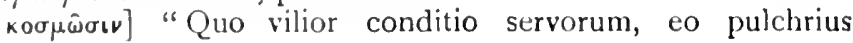


describitur eorum pietas," Bengel ("that they may do worshippe to the doctrine," Tynd. Cranmer). The very difficulty of the slaves' position-for which see an interesting note in Chrysostom-makes his loyalty redound the more to the credit of the Gospel, and show that it is a Gospel of glory, I Ti I ${ }^{11}$; cf. G. Herbert :

\section{"Who sweeps a room as for thy laws} Makes that and the action fine."

The notes of St. Thomas Aquinas on vv. ${ }^{2-10}$ show a shrewd knowledge of human nature, and the appropriateness of each quality to be pressed upon each class.

11-14. The reason and motive power for this appeal-the enabling grace of God.

This dogmatic statement is introduced as the basis of the previous appeal, cf. I $\mathrm{Ti} 3^{15.16}$; "do this for you can, God's grace was given for this very purpose." It springs directly out of the command to slaves, 9.10 , but certainly includes ${ }^{2-8}$, and probably also 1. "Teach rightly, for God's grace was an educating grace: let each class in the household live a true Christian life, for God's grace was given to all classes to make possible such a life." Hence the emphasis lies on $\pi \hat{\alpha} \sigma \iota v \dot{\alpha} v \theta \rho \dot{\omega}-$

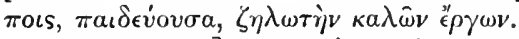

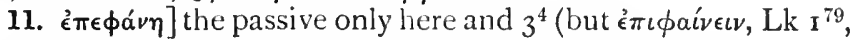
Acts $27^{20}$ ) in N.T. but common in LXX, Josephus, Inscrr. The essential meaning is to appear suddenly upon a scene, and it is used particularly ( $a$ ) of divine interposition, especially to aid (cf. Gen $35^{7}, 3$ Mac $6^{9}$, so é $\pi \iota \phi a ́ v \epsilon \iota a, 2$ Mac $2^{21} 3^{2+} 12^{22} 14^{15}$; and for pagan illustrations, v. M.M. s.v.), "Apparuit gratia Dei," Vulg: (b) of the dawning of light upon darkness ( $\mathrm{Nu} 6^{25}$, Ps $30^{16}{ }^{11} 7^{27}$ etc.), "illuxit gratia Dei" (Jerome). The context here ( $\left.\sigma \omega \tau \dot{\eta} \rho \rho^{\circ}\right)$ suggests the former shade of meaning. The grace of God came to the aid of our need, the reference being to the whole life of Christ, Incarnation and Death, cf. ${ }^{14}$; in 2 Ti $\mathbf{I}^{10}$ the thought of light is more prominent. For further illustrations see excellent notes in Ezra Abbot, Critical Essays, p. 454; Milligan on III Thess., p. I48 ; Justin Martyr (Apol. i. 5 and 14 ) contrasts the 'ं $\pi \iota \phi a ́ v \epsilon \iota \iota \iota$ of dæmons in drearns and other ways, leading to immoral acts, with the $\dot{\epsilon} \pi \iota \phi \dot{u}^{\nu} \epsilon \iota a$ of Christ leading to a life of love.

$\sigma \omega \tau \dot{p} \rho \operatorname{os}]$ taking up $\sigma \omega \tau \hat{\eta} \rho \mathrm{s}^{10}$ and anticipating ${ }^{14}$, bringing salvation from the power of sin to all.

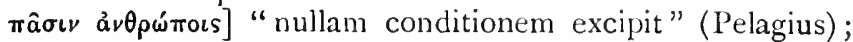
"etiam servis, etiam gentibus," cf. $3^{2}$ (Bengel). The first thought is certainly right- " to all classes of men, even slaves, enabling all to live true lives": the second thought is perhaps 
also suggested by the reference to the effect on the heathen world, 5.8.10: the message of salvation is intended for all, so you need not despair of winning any by your lives, cf. I ' $\mathrm{Ti}^{4}$ $4^{10}$.

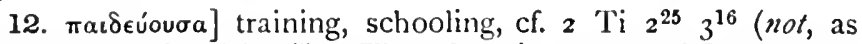
more often, "chastising "). The educative power of God's grace is dwelt upon, as the context is concerned with sound teaching. The thought is akin to the Greek conception of redemption from ignorance; but this is not un-Pauline, and the primary thought is redemption from moral evil.

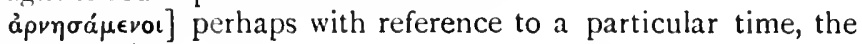
time of baptism.

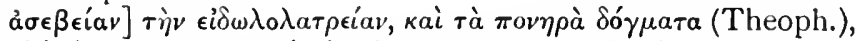
but this is too narrow; it is the contrast to $\epsilon \dot{v} \sigma \epsilon \beta \hat{\omega} s$. Impiety, all wrong thoughts about God, and the actions that follow from it, which marked the heathen $\left(\tau \eta^{\prime} v\right)$ life, cf. Jude ${ }^{15-18}$; "impietatem et sæcularia desideria" (Vulg.).

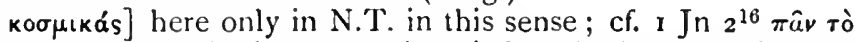

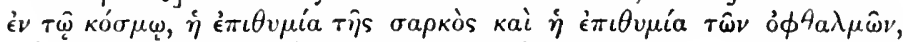

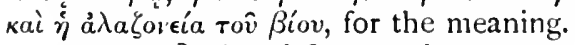

$\sigma \omega \phi p o ́ v \omega s]$ placed first, as the contrast to $\dot{\epsilon} \pi \imath \theta v \mu i a \iota$ and as the characteristic word of the whole chapter: with self-control, with respect for the rights of others, with true piety towards God.

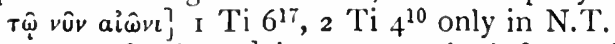

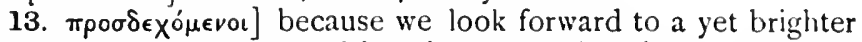
future, when all that is good in this present life will be rewarded and completed; cf. I Cor $1^{7}, 2 \mathrm{Th}^{7-12}$. To the writer as he approached death expectation had grown into love, $2 \mathrm{Ti} 4^{8}$.

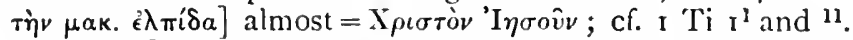

$\dot{\epsilon} \pi\left\llcorner\phi \alpha \dot{v} \in\llcorner\alpha v]\right.$ in N.T., only here and 2 Th $2^{8}$, , Ti $6^{14}, 2$ Ti ${ }^{10}$ $4^{1}$ and ${ }^{8}$; cf. note on $\dot{\epsilon} \pi \epsilon \phi^{\prime}{ }^{\prime} \eta^{11}$. The word was applied to the accession of a Roman Emperor (cf. Milligan on III Thess., p. I 48): that might be in the writer's mind here (cf. next note and $\mathrm{I}$ Ti $6^{15}, 2 \mathrm{Ti}^{1}$ )-the taking of the kingdom by the true king.

Tîs $\delta \dot{\delta} \xi \eta s]$ The full manifestation of all that Christ is in Himself and in His saints; cf. I 'Ti $\mathrm{I}^{11}$ note, $2 \mathrm{Co} 3^{18}, 2 \mathrm{Th} \mathrm{I}^{10}{ }_{\text {ö }}$ tav

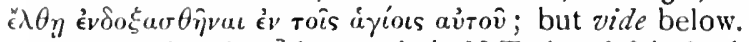

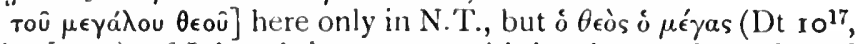
Neh $\mathrm{I}^{5}$ etc.), of Jehovah in contrast with heathen gods, and used by heathen of their gods and goddesses; cf. Acts $19^{27} \tau \hat{\eta} s$

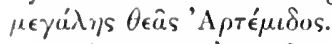

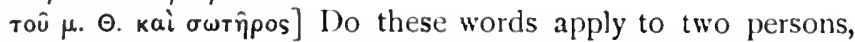
"of Our Great God and of our Saviour," or to one, "of Our Great God and Saviour"? Probably to one, and that one Jesus Christ ; cf. I Th $1^{10}, \mathrm{CO}^{\mathrm{7}}$. 
(i) For-

(a) This is the natural (though not necessary) construction of two substantives after one article, and the

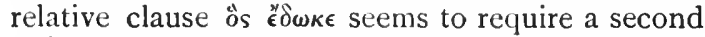
article with $\sigma \omega \tau \hat{\eta} \rho o s$, if that refers to a separate person.

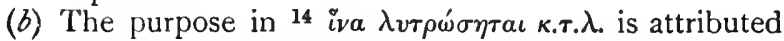
to Jehovah in the O.T., but here to Jesus Christ : so that it is natural that Jesus Christ should be identified with $\mathrm{Him}$ in this phrase also.

(c) There is possibly an intentional contrast with the Roman Emperor or (? and) with the object of worship in the mysteries. The combination $\sigma \omega \tau \grave{\eta} \rho$

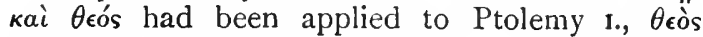

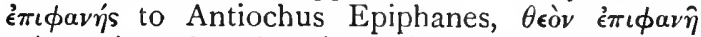

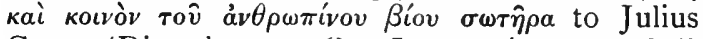
Cæsar (Dittenberger, Gr. Inscr. xvi. 2. 3 ; Syll. Inscr. Gr. 347. 6). So Osiris was called Lord and Saviour in the Isis mystery.

(d) In Jewish Apocalyptic there is sometimes an anticipation of a manifestation of Jehovah, sometimes of that of a Messiah, but not of both.

(ii) On the other hand, the identification is-

(a) Against the general usage of the earlier Epistles, though Ro $9^{5}$ is probably an exception.

(b) Against the usage of the Past. Epistles, cf. $3^{4-6}$, I Ti $\mathrm{I}^{1} \mathbf{2}^{5.6}, 2 \mathrm{Ti} \mathbf{I}^{2}$; but those passages speak of Christ's past or present work, this of His future glorification.

(c) Against the distinction between the glory of the Son and that of the Father, Lk $9^{26}$, Mt $\mathbf{I}^{27}$. Patristic evidence is divided. Justin Martyr. Apol.

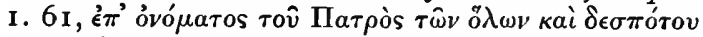

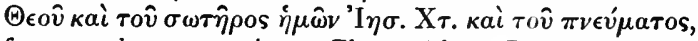
favours the separation; Clem. Alex. Protr. c. I, §7, the identification, quoting the passage as a proof that Christ is both God and man ; Chrys., Jerome, Thdt., and (apparently) Theod.-Mops. and Pelagius, and the Liturgy of St. Basil (Brightman, L.E.W., p. 402), all support Clement's view, Ambrosiaster that of Justin.

The question is not one of doctrinal importance: on the theory of separation Jesus Christ is still placed on a level with the great God, as a manifestation of His glory, and as having effected Jehovah's work of salvation. Chrysostom's question

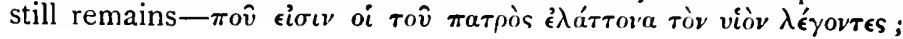


Dr. Hort (on Jas $2^{1}$ and Add. Note, p. 103 : and so Lange, von Hengel, Schenkel, quoted in Ezra Abbot, p. 450) takes $\tau \hat{\eta} s \delta o ́ \xi \eta s$

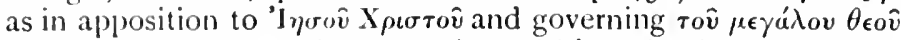

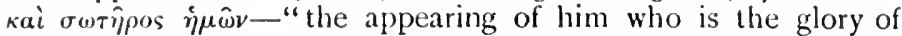
the great God and our Saviour"-i.e. of Jesus Christ, the glory of the Father, who is both the great God and our Saviour; supposing the thought of the Shechinah or the Glory of God (cf. Burney, Aramaic Origin of the Fourth Gospel, pp. 36, 37) to have been transferred almost as a fixed title to Christ, as the thought of the Word was transferred to Him in the Fourth

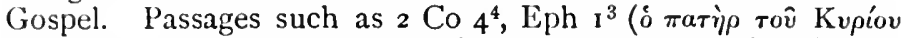

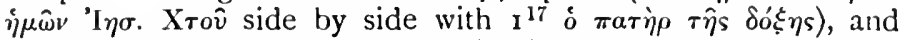
perhaps Jas $2^{1}$, would support this : in a similar way Christ is

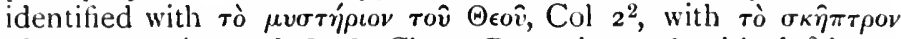
rìs $\mu \epsilon \gamma \alpha \lambda \omega \sigma \dot{v} \eta \eta s \tau o \hat{v} \Theta \epsilon o \hat{v}$, Clem. Rom. i. c. 16 , with $\dot{\eta} \delta \dot{v} v \alpha \mu \iota s$

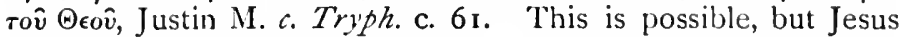
Christ has Himself been called "our Saviour" in this Epistle, $\mathbf{I}^{4}$, and the reasons urged above seem to decide in favour of referring the whole phrase to Jesus Christ. For a very full discussion of the history of the interpretation, cf. Ezra Abbot, Critical Essays,

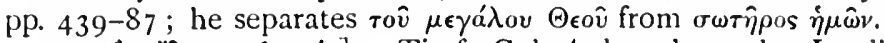

14. ôs é $\delta \omega \kappa \in v$ éautóv] I $\mathrm{Ti}^{6}$, Gal ${ }^{4}$, based on the Lord's own saying, $\mathrm{Mk} 10^{45}$. The gift is the gift of the whole life, but principally of the life surrendered in death ; cf. I Co I $^{23} \pi \alpha \rho \epsilon \delta i \delta \epsilon \tau o$, Phil $2^{8}$, Eph $5^{25}$.

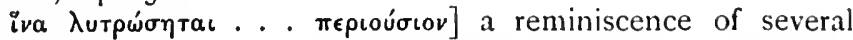

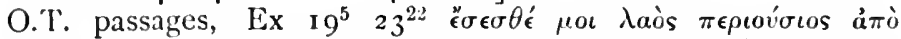

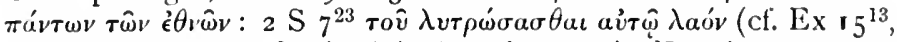

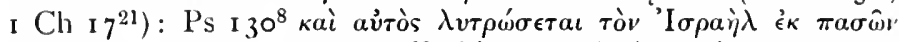

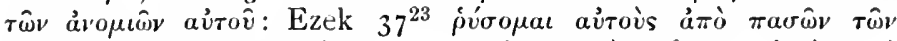

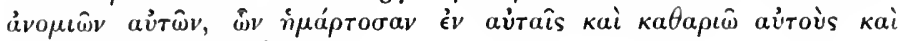

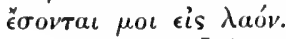

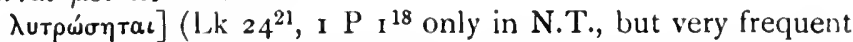
in LXX). "Rescue," "deliver," though the previous words

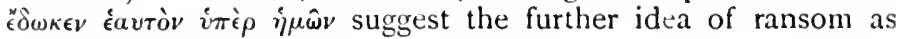
lying in the background.

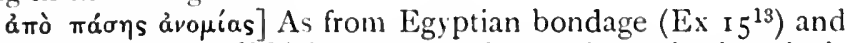
from Babylon (Is $44^{22-24}$ ) in the past : hence the main thought is rescue from the power, not from the guilt of sin.

к $\alpha$ apí⿴囗十] from Ezek $37^{23}$ (supra). The original reference was probably to the sprinkling of the people with the blood of the covenant, cf. Ex $23^{22} 24^{8}$; so that the thought is still of

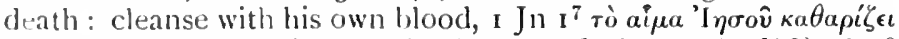

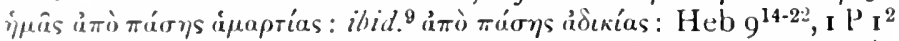

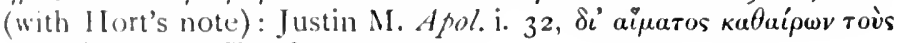

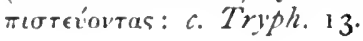


The word also looks back to $\mathrm{I}^{15}$; there is a cleansing needed, but no Jewish ceremonial cleansing to be repeated from time to time, but a cleansing of the heart (cf. Acts $15^{9}$ ) which has been effected by Christ Himself: perhaps it also anticipates $3^{5}$ and contains a reference to the cleansing of baptism ; cf. Eph $5^{25.26}$, I Co $6^{11}$.

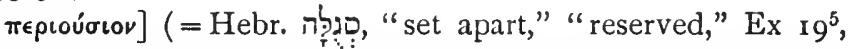
Dt $7^{6} 14^{2}{ }^{26^{18}}$ ) is not found except in the LXX, prob. signifying "that which is over and above," the special portion which a conqueror took for himself before the spoil was divided, or the first-fruits which the owner takes from his threshing floor (cf.

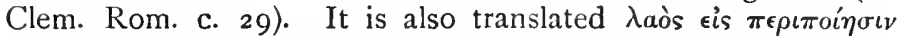

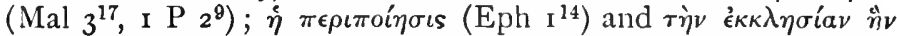
$\pi \epsilon \rho \iota \epsilon \pi \circ \eta^{\prime} \sigma \alpha \tau o$ (Acts $20^{28}$ ) are virtually translations of the same word. It implies the thought of Christ as a triumphant king (For full discussion of the word, vide Hort on $1 \mathrm{P}^{2}$; Lightfoot, Revision of N.T., Appendix.)

The Latin translations vary: "abundantem," Clarom.; "acceptabilem," Vulg. ; " egregium," Jerome ; "proprium," Theodore: cf. "domesticam Dei gentem," Tert. Apol. I 8. According to Jerome, Symmachus was the first to use the Latin word peculiarem, transliterating it into Greek; and from him Jerome, though leaving "acceptabilem" here and "populus adquisitionis" in I $\mathrm{P}_{2}$, used it in the O.T., and it has come thence into our English versions. It is derived from the peculium, the private property of a slave.

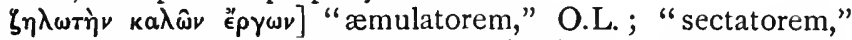
Vulg.; "a pursuer," Rheims ; "fervently given to good works," Tynd. Israel had been a peculiar people, to keep God's commandments (Dt 2618); the Christian Church has to have an eager enthusiasm for and to take the lead in all that is

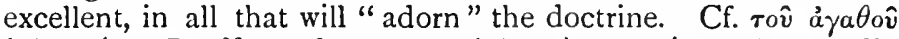
$\zeta \eta \lambda \omega \tau a i$, I P $3^{13}$; and contrast $\zeta \eta \lambda \omega \tau a i$ rov̂ vó $\mu o v$, Acts $2 \mathrm{I}^{20}$;

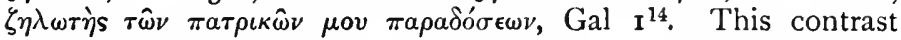
may be conscious here, cf. $\mathbf{I}^{14.15}$, I $\mathrm{Ti}^{\mathbf{r}^{7}}$. Epictetus would

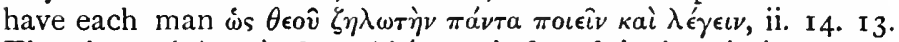

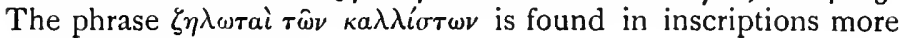
than once (M.M. s.v.).

The conception of the Church, as the chosen people, which has taken the place of and has to do the work of the Jewish nation, is specially marked in I Peter, but it is equally clear in St. Paul ; cf. Gal $6^{16}$ "the Israel of God"; Phil $3^{3}$ i $\mu \epsilon \hat{\imath} \mathbf{s} \epsilon \sigma \mu \grave{\varepsilon} \nu$ $\dot{\eta} \pi \epsilon \rho$ r $о \mu \dot{\eta}$, and it underlies the Lord's choice of twelve apostles

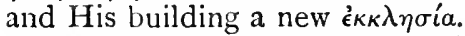

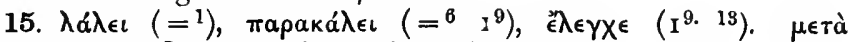

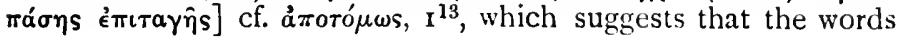




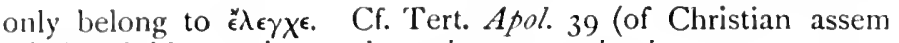
biies), "ibidem etiam exhortationes, castigationes, et censura divina."

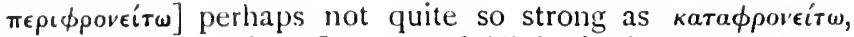
I Ti $4^{12}$, "ignore," but Chrys. and Thdt. both treat the two as symonymous. Calvin assumes that the Epistle would be read in public, so that this command is virtually addressed to the church rather than to Titus. It probably implies advice both to 'Titus and to his hearers.

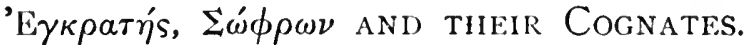

$\Sigma \dot{\omega} \phi \rho \omega \nu$ and its cognates are specially characteristic of the Past. Epp., not occurring at all in the earlier letters: 'ं $\gamma \kappa \rho а \tau \eta / s$ and its cognates are comparatively rare in each set, once in Past.

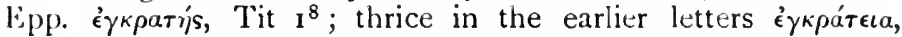
Gal $5^{23}$; $\dot{\epsilon} \gamma \kappa \rho a \tau \epsilon \dot{\epsilon} \epsilon \theta a \iota, 1$ Co $7^{9} 9^{25}$. In 'Tit $1^{8}$ both are stated

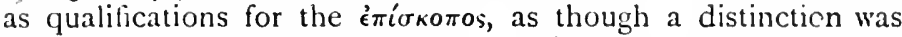
consciously drawn between them. 'This would probably be the

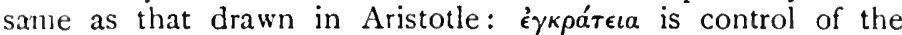
bodily passions with deliberate effort, a self-mastery which keeps

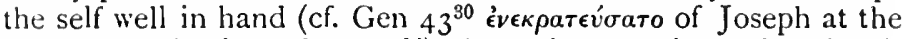
sight of Benjamin, I Sam $\left.{ }_{1} 3^{12}\right)$, the main stress is on the will; it is applied most frequently to sexual and all bodily passions (1 Co $7^{9} 9^{25}$ ), but also with the widest possible reference $\left(\mathrm{Gal} 5^{23}, 2 \mathrm{P}^{6} \mathbf{1}^{6}\right.$.

$\sigma \omega \phi \rho o \sigma v i v \eta$ is a free and willing control which no longer requires effort; the main stress is on the judgment which reoognizes the true relation between body and spirit, a rational self-control, a sound mind which always "keeps its head." So in Plato's application of it to the state it is the recognition of the true relation of each part to the other, and, while common to all classes, it is most important and effective in the ruler. But in popular usage it tended to be regarded as the peculiar virtue of women, in the sunse both of sexual self-control and of practical wisdom, and of the voung. Cf. Xenophon, Econom.

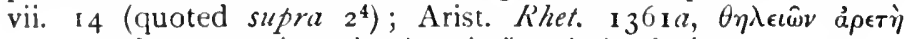

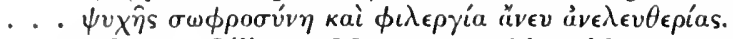

Professor Gilbert Murray would add a new thought to ow poorviv $\eta$ which would make the distinction stronger; he sees in it a saving power which would give it an altruistic effect,

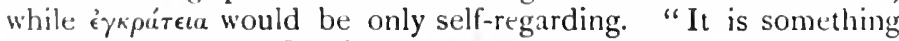
like 'Temperance, Gentleness, Mercy; sometimes Innocence, never merely Caution; a tempering of dominant emotions by gentler thought. But its derivation is interesting. The adjective 


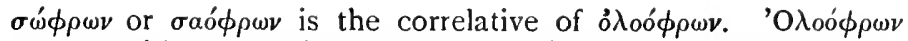
means 'with destructive thoughts'; $\sigma \omega \phi \phi \rho \nu$ means 'with saving thoughts.' Plutarch, when the force of the word was dead, actually used this paraphrase to express this same idea (vôv $v$

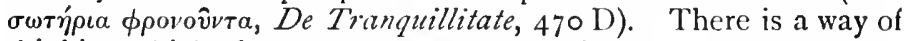
thinking which destroys and a way which saves. The man or woman who is $\sigma \omega \dot{\phi} \phi \omega \nu$ walks among the beauties and perils of the world, feeling the love, joy, anger, and the rest ; and through all has that in his mind which saves. Whom does it save? Not him only, but, as we should say, the whole situation. It saves the imminent evil from coming to be" (The Rise of the Greek Epic, p. 27). This is excellent as a description of its usage; but I doubt whether it springs from the derivation, which implies a "sound" rather than a "saving" mind, and Plutarch's words are not applied to the $\sigma \omega \dot{\phi} \phi \omega \nu$ but to $\dot{o}$ voviv $\stackrel{\epsilon}{\epsilon} \chi \omega \nu$.

It is, however, very doubtful whether a distinction between the two words is to be pressed always in Hellenistic Greek. A

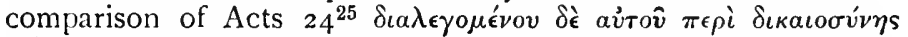

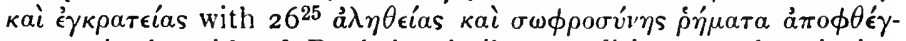

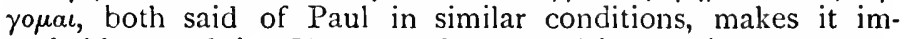
probable; and in Clement of Alexandria é $\gamma \kappa \rho a ́ \tau \epsilon \iota u$ becomes more positive: "it now forms the basis of reasonable selflimitation in regard to all the passions and desires. The cause of this improved conception of $\dot{\epsilon}^{\prime} \gamma \rho \alpha \dot{\tau} \tau \epsilon \iota$ is probably due in part to the less hostile attitude taken by Christianity towards the body and the emotional nature than that which prevailed before" (T. B. Strong, Bampton Lectures, p. I 70). Cf. also Hermas, Vis. 3. viii., where it is one of the seven women round

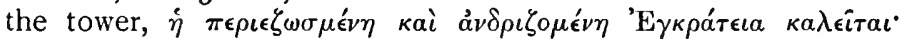

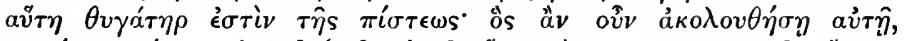

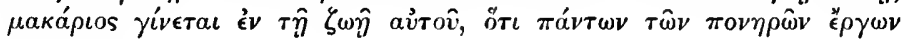

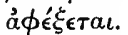

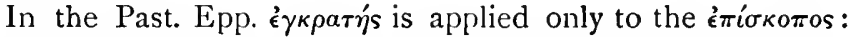
$\sigma \omega \phi \phi \omega \nu$ to every class-to those in authority, I $3^{2}$, Tit $I^{8}$ (the 'ं $\pi^{\prime} \sigma \kappa o \pi \%$ ), II $I^{7}$ (St. Paul and Timothy and all teachers): to old men, Tit $2^{2}$; to women, I $2^{9}$; to the elder women, Tit $2^{4}$; to young women, Tit $2^{5}$; to young men, Tit $2^{6}$-generally in the widest sense of self-control, once with special ref rence to selfcontrol in married life, $12^{15}$. It is one of the essential character. istics of the Christian life, one of the purposes of the Incarnation, Tit $2^{12}$.

Both words and their cognates are rare in the O.T., but they come, often with conscious reference to the Platonic cardinal

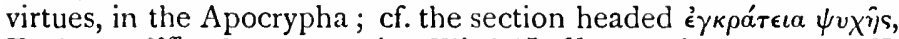
Ecclus I $8^{\text {:0ff. }}$; for $\sigma \omega \phi \rho \circ \sigma u ́ v \eta$, Wisd $8^{7} 9^{11} \sigma \omega \phi \rho o ́ v \omega s, 2$ Mac $4^{97}$, 


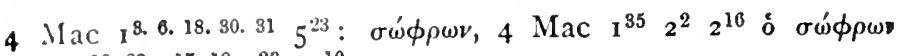
voûs, $2^{18.23} 3^{17.19} 7^{23} \mathrm{I}^{10}$.

fior fuller illustrations, cf. Trench, Syn. \$\& xx. and xxi.; Burton, ICC, Gal. p. 318; F. M. Cornford in Classical Quarterly, Oct. 1912, pp. $249 \mathrm{ff}$; R. Hackforth in Classical Quarterly, Oct. 1913, pp. 265 ff.

iii. 1-8. The duty of Christians to the outer world: obedience to government, activity in good works, gentleness and meekness in private life, 1. 2. And the motive for such conduct: the duty of imitating God's love to us who has saved us from our sins, ${ }^{3-8}$.

9-11. The duty of avoiding useless discussion ${ }^{9}$ and fastious opponents, ${ }^{10.11}$.

This section is connected with the preceding chapters: vv. ${ }^{1-8}$ with ch. 2 ; vv. ${ }^{9-11}$ with ch. 1. Ch. 2 had given commands to different classes, this gives one command common to all : that had emphasized the duty of subjection in the younger women and in slaves, this extends it to all classes: that had hinted at the effect of Christian lives on the heathen, this brings out the lirect duty which Christians owe to them: that had dwelt on God's saving grace as enabling Christians to do good works, this on God's gift of a new birth as putting them under an obligation to do them.

In the same way ${ }^{9-11}$ pick up the main thoughts of $\mathrm{I}^{10-16}$, the duty of avoiding Jewish discussions $\left(\mathrm{I}^{14} 3^{9}\right)$, and the duty of rebuke to opponents $\left(1^{13} 3^{10.11}\right)$.

The keynote of the chapter is usefulness. Christians have to be useful citizens, ready for every good work; only such teaching is to be given as is useful to the world $\left({ }^{8}\right)$ : "our friends" are to be ready to help others in need: they are not to be unfruitful $\left({ }^{14}\right)$. Titus himself is to be useful to Zenas and Apollos when they arrive $\left({ }^{13}\right)$.

For the whole section cf. Ro $12^{17}-13^{7}$, of which there may be a reminiscence.

Paraphrase. There is one thing of which you must remind them all, free and slaves alike-that is, to be loyal subjects to the Government and its officials, to obey any commands which they issue, to be on the look out to help in any kind of good work, to speak evil of none, to avoid all quarrels, not to stand on their own rights lut to be large-hearted, never failing to show gentleness to any one. This is our bounden duty, for there was a time when we were as void of understanding as they are now; we too were disobedient, easily misled, the slaves of passions and pleasures of many kinds, passing our life in ill-will and envy of others, worthy of hate and hating one another. 
"But when in gracious love for man Our Saviour God unveiled His plan, 'Twas not for merit of our own But of His pitying care alone He saved us, by a heavenly birth Cleansing away the stains of earth And on our heads in rich largess Pouring His Spirit's holiness."

All this $\mathrm{He}$ did that so being justified by $\mathrm{His}$ free gift we might become heirs, through hope, of eternal life. This saying is worthy of entire faith, and on all these points I wish you to insist, in the hope that those who have put faith in the message of God may set themselves to make honourable deeds the very business of their life. These truths are excellent in themselves and full of profit to others. But as for foolish speculations and genealogies, and strifes and wranglings about the Jewish law, give them a wide berth, for they are profitless and lead to nothing. If a man is self-willed and factious, warn him once, warn him again, but then avoid him, knowing that a man of such a character is perverted and sins, being condemned by his own action.

As soon as I shall send Artemas or Tychicus to you, make haste to come to Nicopolis to join me, for that is where I have decided to winter. Help forward on their journey with all diligence Zenas and Apollos: see that they have everything they want. Yes, and let all our brethren learn to make a real business of honourable works, that they may be able to help in such cases of need, that so they may not deserve the taunt of being "idle drones." All my companions send you greeting: do you give my greeting to all who love us in a common faith. God's grace be with you all.

1-3. Duty to the heathen world: (a) obedience to government, cf. 1 Ti $2^{1.2}$ notes, and (more closely) Ro $13^{1-7}$, P $3^{8-17}$. Such a command would be necessary at any time and place to Christians, who might regard their allegiance to Christ as exempting them from allegiance to the Pagan Emperor (cf. Acts $17^{6}$ $24^{5}$ ), and it is specially enforced in St. Paul's letter to Rome and St. Peter's letter from Rome; but it has a peculiar appropriateness in writing to Crete, partly because of the large number of Jews $\left(\mathrm{I}^{10}\right)$ in the Christian body who doubtless there, as at Rome, would be "assidue tumultuantes" (Suet. Claud. c. 25); partly because of the turbulent character of the Cretans them-

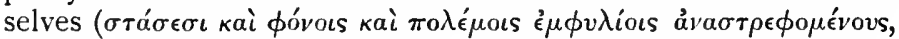
Polyb. vi. 46. 9), who long fretted against their subjugation by Rome (cf. Dio Cassius, xxxvi. r, quoted in Wetstein).

1. $\left.\dot{\pi} \pi \mu_{i}^{\prime} \mu \nu \eta \sigma \kappa \epsilon\right]$ perhaps suggests that St. Paul had himself laid stress on this at the time of his visit to Crete; but they need a reminder. 


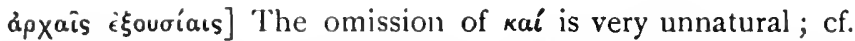

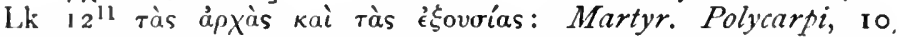

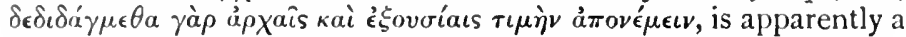
reminiscence of this place, and suggests that kai has accidentally dropped out; cf. Introd., p. xxxviii.

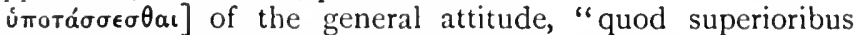
debent subditi reverentiam subjectionis" (Thom. Aq.).

$\pi \in \iota \theta a p X \in \hat{i v}]$ of obedience to particular commands, e.g. the payment of tribute and dues, Ro $13^{6}$; cf. Xen. Cyr. viii. I. 3 ,

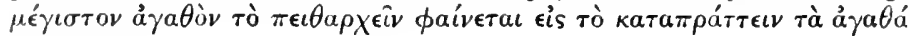
(Alford).

(b) Activity in good works.

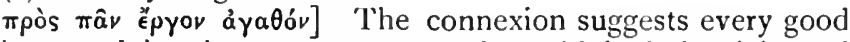
work started by the government, and would include civic and municipal duties; but it need not be limited to these: cf. Clem. Rom. i. c. 33, possibly a reminiscence of, certainly an interesting comment on, this phrase.

ảyatóv] perhaps limiting; provided that it is good; cf. Thom. Aq. "alioquin non esset obediendum," cf. ${ }^{3}$ note and $2^{8}$ ncte.

(c) Gentleness in private life. $2^{23.24}$.

2. ảráxous] (here and I Ti $3^{3}$ only in N.T.), cf. ${ }^{9}$ and 2 'T,

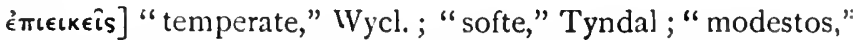
Vulg.; not pressing their own rights, making allowances, remembering that the heathen do not know of the graciousness

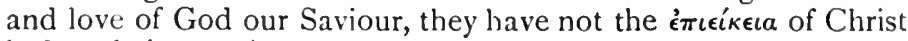
before their eyes ( 2 Co ${ }^{1}{ }^{1}$ ); "large-hearted," "high-hearted," cf.

"Truth's school for certain doth this same allow, High-heartedness doth sometimes teach to bow"

(Lady E. CAREw),

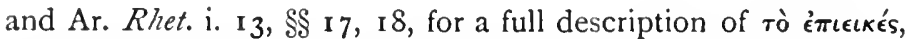
"It is the indulgent consideration of human infirmities. To look not to the mere letter of the law but to the mind of the legislator, not merely to the act done but to the intention of the doer, not to a part but to the whole, not to the character of the actor at the moment but to his general character, to remember good deeds received from him rather than the bad, and the benefits you have received rather than those you have conferred "(Cope). Such a quality would be needed by masters in the treatment of their slaves ( $\mathrm{I} \mathrm{P}_{2}{ }^{18}$ ), but here the reference is

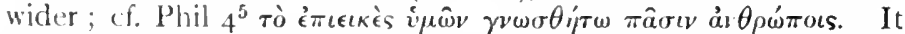
would lee neeted especially in face of persecution; $\mathrm{cf}$. Wisd $2^{\text {s }}$

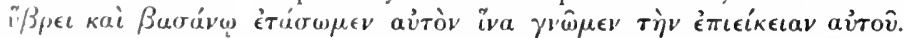
For good accounts of the word, cf. Lightfoot on Phil $4^{5}$, Mayor on Jas $3^{17}$. 
$\pi \hat{a} \sigma a v \dot{\epsilon} \nu \delta$.] perhaps reminiscent of $2^{10}$-as gentle to all men

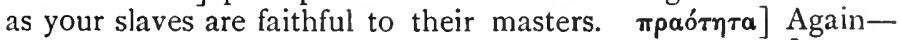

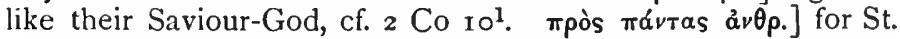
Paul's stress on the duty of Christians to the whole world outside, cf. Ro $12^{17}$, Gal $6^{10}$, Phil $4^{5}$; and for the result of such teaching, cf. Justin M. Apol. i. cc. I4-16; Tert. Apol. c. 36, "civilitas in imperatorem tam vere quam circa omnes necesse habet exhiberi. . . . Nullum bonum sub exceptione personarum administramus."

3-7. Two reasons are given-(a) we ourselves were no better, and therefore are bound to be tolerant and forgiving, cf. Lk $7^{40-50}, \operatorname{Ex~22^{21}}$ : $(b)$ we have been reborn by God's graciousness and loving-kindness, and ought to imitate these qualities; cf.

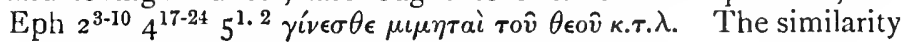
suggests a conscious reminiscence of that Epistle.

3. ávóntol] in intellect, cf. Eph $4^{18}$, Ro $1^{21} ; \dot{a} \pi \epsilon \iota \theta \in \hat{i} s$, in action; primarily, disobedient to human authority; $\mathrm{cf}^{1}{ }^{1}$ and $\mathrm{I}^{6.10}{ }^{10}$, Ro ${ }^{30}$,

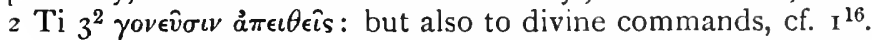

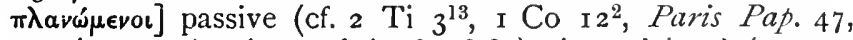

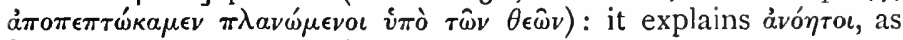
$\delta o v \lambda \epsilon \dot{v} o v \tau \epsilon$ explains $\dot{a} \pi \epsilon \iota \theta \epsilon \hat{\imath}$.

кakia ] "active malice," cf. Eph $4^{31}$; I $\mathrm{P}{ }_{2}^{1}$ with Hort's note.

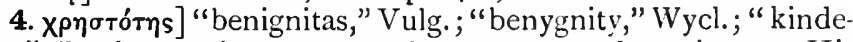
ness," Tynd. ; graciousness, goodness, ever ready to bestow His blessings and to forgive; cf. Trench, Syn. lxiv. The substantive

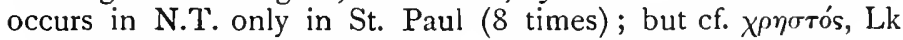
$6^{35}, \mathrm{I} \mathrm{P}^{3}$, and frequently in the Psalms applied to Jehovah.

$\phi i \lambda \alpha \nu \theta \rho \omega \pi i \alpha]$ here and Acts $28^{2}$ (cf. $\phi i \lambda \alpha \nu \theta \rho \omega \pi \omega s, i b i d .27^{3}$ ) only in N.T., but frequent in classical writers and in the LXX of

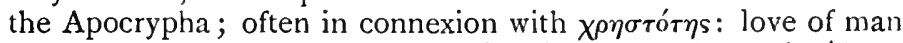
as man, humanity, showing itself in kindliness to equals (Acts, $u b i$ s.), in graciousness to subjects $\left(2 \operatorname{Mac} 14^{9}\right)$, in pity for those in trouble; cf. Clem. Hom. xii. 25-33 (a most interesting

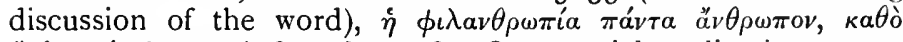

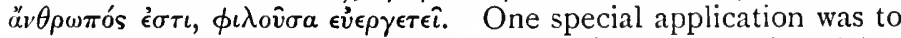

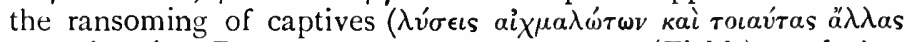
$\phi \iota \lambda \alpha \nu \theta p \omega \pi i a s$, Dem. de Chersoneso, r07. I5 (Field)), and that

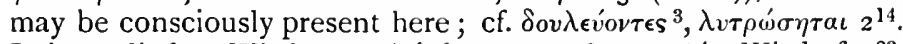

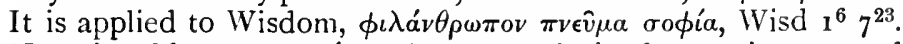

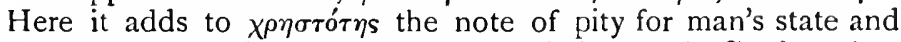
the thought that it extends to all men ( $\pi \dot{a} v \tau a s \quad a v \theta \rho .{ }^{2}$ ); but they are so allied (cf. Field, Ot. Norv., here and on Acts $28^{2}$, and Wetstein here for suggestive illustrations) that the verb is in the singular. The two qualities are chosen in contrast to the conduct of men in the past ${ }^{3}$, and as examples to Christians in the

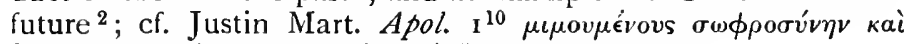

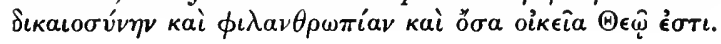




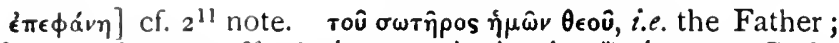

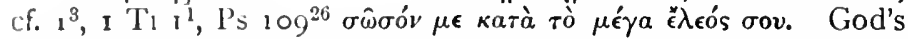
"peculiar people" is, as of old, entirely dependent on His

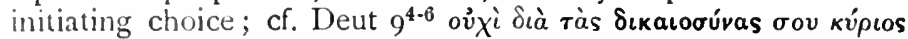

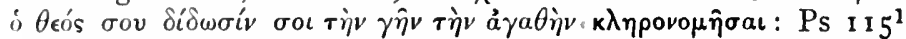

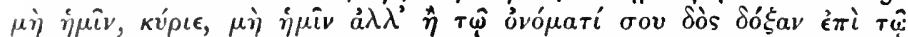
$\dot{\epsilon} \lambda \epsilon^{\prime} \epsilon \iota$ oov. The clause is added to prevent self-complacency and to call for a true response to God's mercy, but with a side reference to past controversy with Pharisaic Judaism; cf. Eph $2^{8.10}$, $2 \mathrm{Ti} \mathrm{I}^{9}$; Clem. Rom. c. 32 (a full comment on this verse, perhaps a reminiscence of it).

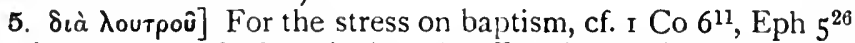
(the instrument of cleansing), I $\mathrm{P}_{3}^{21}$ (of salvation, as here), Jn $3^{5}$ (of new birth). There is probably a conscious reference to $I^{15}$ and $2^{14}$. We needed cleansing, but with more than Jewish ceremonial ablutions, with a washing that would entirely renew our nature.

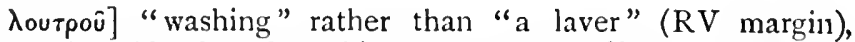
"fountain," Tynd.; cf. Robinson on $E_{p h} 5^{26}$. Justin. Mart.

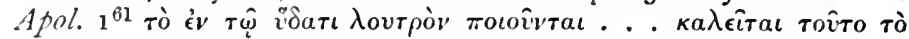

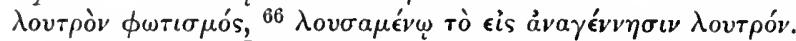

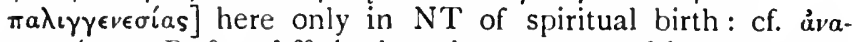
$\gamma \epsilon \gamma \epsilon \nu v \eta \epsilon^{\prime} v o t$, I $\mathrm{P}_{1}{ }^{3}$ and ${ }^{23}$, both perhaps suggested by the Lord's saying, afterwards recorded in $\mathrm{Jn} 3^{3-5}$. Cf. Justin Mart. Apol.

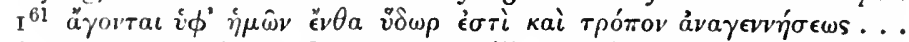

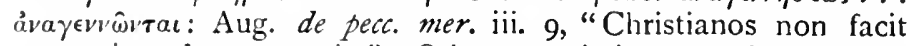
generatio sed regeneratio." Other associations may have led to the choice of the word. (I) The analogy of the Rabbinic title

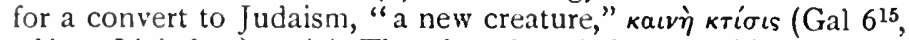
ubi $\%$ Lightfoot). (2) The thought of the new birth of one initiated in the Greek mysteries, a rebirth which followed a ritual bathing; cf. Apul. Met. xi. 23-25. (3) The Stoic use of the word for the periodical restoration of the world after its periodical destruction by fire: this is less obvious, but there may be a conscious contrast between the Stoic and the Christian $\pi a \lambda \iota \gamma \gamma \epsilon \nu$. eria-" "the one by fire the other by water: the one physical, the other spiritual; the one subject to periodical relapses and renewal, the other occurring once for all and issuing in an endless life" (Swete, The Holy Spirit in N.T., App. M). Philo seems to apply this Stoic thought to the Flood (vit. Mos. ii. 12 of Noah,

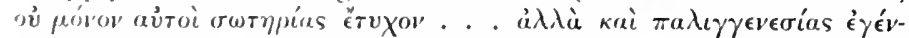

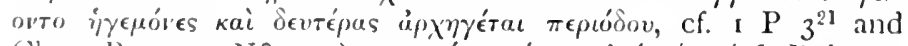

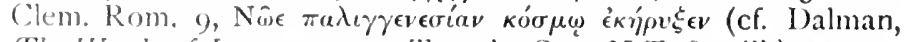
The llords of Jesus, p. 177 ; 'Trench, Syn. N.T., \$ xviii.).

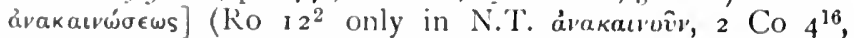
$\mathrm{Col} 3^{10}$ only; both perhaps coined by St. Paul, M.M. s.v.), 
probably governed by $\lambda$ ovт $\rho \hat{v}$, "per lavacrum regenerationis et renovationis," Vulg., referring to the moment of baptism; cf. Jn $3^{5}$, Acts $9^{17-19}, 2$ Co $5^{17}$, Gal $6^{15} \kappa a \iota v \dot{\eta} \kappa \tau i ́ \sigma \iota s$, Ezek $3^{6^{25.26}} \stackrel{\rho}{\rho} \alpha \nu \hat{\omega}$

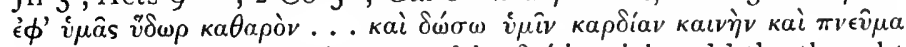
$\kappa a \iota v \grave{\nu} \delta \dot{\omega} \sigma \omega \dot{\epsilon} v \dot{v} \mu \hat{\imath} v$. If governed by $\delta \iota \dot{a}$ it might add the thought of subsequent daily renewal, or of the fuller gift of the laying on of hands in Confirmation (Chase, Confirmation in the Apostolic Age, p. 98).

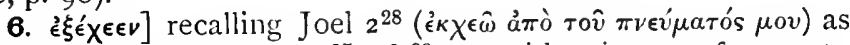
used by St. Peter in Acts ${ }^{27}$, cf. $^{33}$; so with primary reference to Pentecost, but to Pentecost as an abiding reality affecting each Christian.

$\pi \lambda$ ouoi $\omega s]$ cf. Eph $2^{4}$. "abunde," Vulg. ; "ditissime," Theod., sufficient for all men (cf. $2^{11}$ ), and for all the needs of each: "ad opulentiam sufficit quod, quantulumcunque nobis

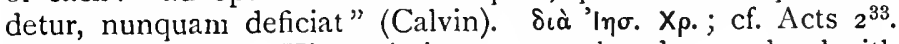
тoû $\boldsymbol{\sigma} \omega \tau \hat{\eta}$ pos $\dot{\eta} \mu \hat{\omega} v$. His work is ance placed on a level with God's; cf. $2^{13} \mathrm{n}$.

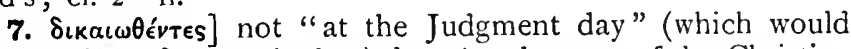
make $\kappa a \tau$ " $" \bar{\epsilon} \lambda \iota \delta \alpha$ meaningless), but "at the start of the Christian life," as in Ro 3. 4, Gal 3-5: "we at once might become heirs of life, yet with a further hope (cf. $2^{13}$ ) that it will become fuller and eternal"; cf. $\mathrm{r}^{2}$, Ro $8^{17}, \mathrm{Gal} 4^{6 .}$.

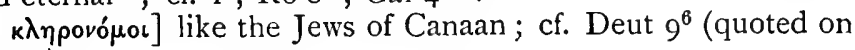
p. 154$)$.

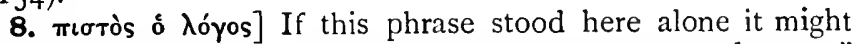
well be "Faithful is the whole gospel message entrusted to me" (cf. $\mathrm{I}^{3}$ and ${ }^{9}$ ), but it is a formula common to and confined to the P.E., I $\operatorname{Ti}^{15} 3^{1} 4^{9}$, 2 Ti $2^{11}$ : perhaps a marginal gloss by some scribe subsequently embodied in the text (so C. H. Turner, Inaugural Lecture, p. 2 I) ; more probably the writer's own note, either calling attention to the importance of what he has said

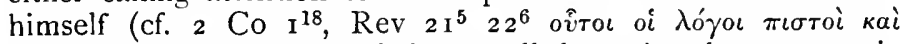
$\left.\dot{\alpha} \lambda \eta \theta_{c v o} \epsilon^{\epsilon} i \sigma l\right)$, or (more probably, as all the sayings have a gnomic and rhythmical character and bear on salvation) quoting some

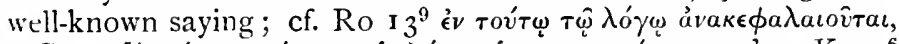

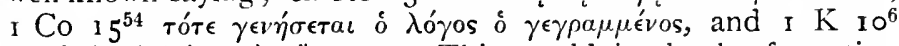

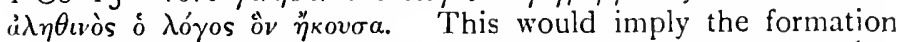
of some collection of Christian maxims analogous to the $\lambda o^{\prime}$ ou rôे кupíov 'I $\eta \sigma o \hat{v}$, Acts $20^{35}$, and the Oxyrhynchus Sayings, Pap. Oxyr. iv. 654. Here the Saying is contained in ${ }^{5-7}$, either in whole or in part, e.g. ${ }^{5}$ only, ${ }^{6}$ and 7 being the writer's own expansion.

An attempt has been made recently (cf. Jour. Th. Stud., April $1923, p .310$ ) to prove that $\delta$ hó ${ }^{2}$ os here and wherever it occurs in the Pastorals is used in the Johannine sense of the 


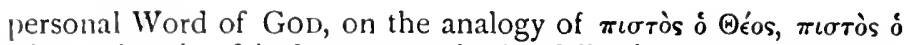
кúpros: but in $\mathbf{1}^{\mathbf{3}}$ it does not suit the following words, $\dot{\epsilon} v \kappa \eta \rho \dot{\gamma} \gamma$ -

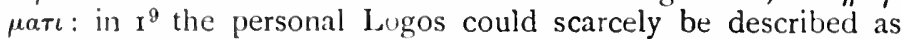

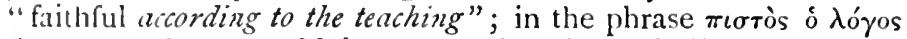
the personal use would be appropriate in 2 ' $\mathrm{Ti}_{2}{ }^{11}$, but it is not

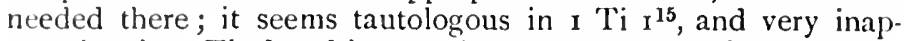
propriate in I Ti $3^{\mathbf{l}}$ and here; whereas the explanation of it as a quotation is appropriate in each passage.

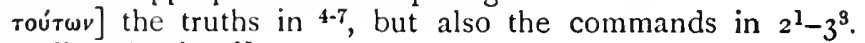
It recalls $\tau a \hat{v} \tau \alpha$ in $2^{15}$.

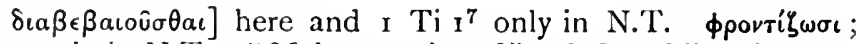
here only in N.T. "Make a point of"; cf. Grenfell and Hunt,

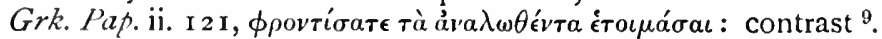

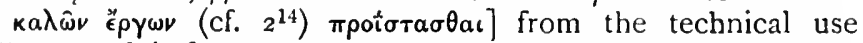
= "to stand before a shop as a tradesman selling his goods," "to practise a profession" (cf. Plutarch, Vit. Per. 24, of Aspasia,

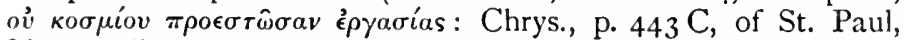

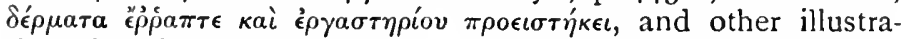
tions in Field, Ot. Norvic.). Here the application may be: (a) literal, "to profess honest occupations" (R.V. margin), "to

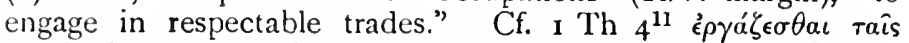

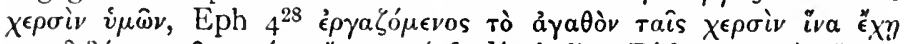

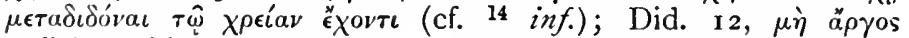

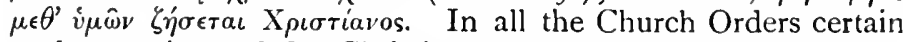
trades are banned for Christians, such as the making of idols, acting, dancing on the stage, fighting as a gladiator, dealing in witchcraft. Cf. Egyptian Church Order, p. 149; Canones Hippol. $\$ \S 65-67$; Const. Apost. viii. 3 ; and Tertullian, de Idololatria, passim.

Or (b) metaphorical, "to make a business of all that is excellent," to be active in all good works: "bonis operibus preesse," Vulg.; " bona opera exercere," Herm. Sim. x. 4; " ad bona opera docenda præesse"; Pelag. "misericordiæ studere," Ambrosiast., and Chrys. $(765 \mathrm{~A}-767 \mathrm{D})$ refers it to almsgiving. Cf. Clem. Rom. 34 (which seems to recall this chapter), тротрє́тєта८

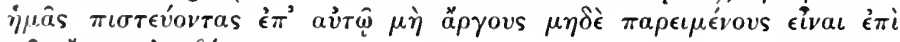

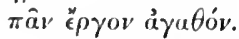

Here the wider sense is strongly supported by $2^{\mathbf{1 4}}$ and $3^{2}$, where there is no limitation, and by the analogy of Eph $2^{10}$; but the narrower reference may have been consciously included and seems to be the primary meaning in ${ }^{14}$.

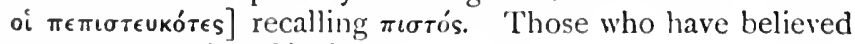
a message so worthy of belief.

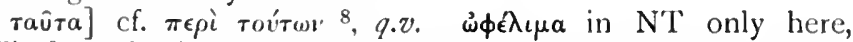
I Ti $4^{8}, 2$ Ti $3^{16}$; not in I.XX, but frequently in classical writers in combination with $\kappa$ adós; $v$. illustrations in Wetstein. 


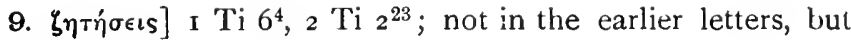
frequent in Acts.

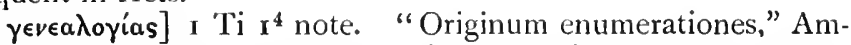
brost., who refers it to Jewish pride in their descent from the patriarchs, and to legends about the burial of Moses, the building of the Temple, etc. Similarly Jerome (whose note here with his account of Origen's work on the O.T., and of the teaching of Isaac, his own contemporary at Rome, is full of historical interest).

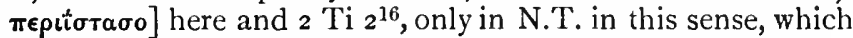
is late and censured as a solecism by Lucian, but common in Josephus, M. Aurelius, etc.

àv $\omega \phi \in \lambda \in \hat{\imath}$ s here and Heb $7^{18}$ only in N.T.; cf. Ign. Magn. 8,

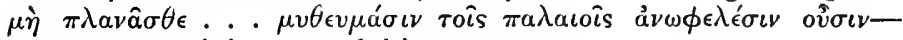
perhaps a reminiscence of this verse.

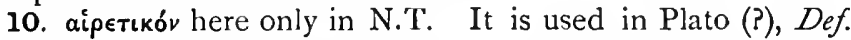
4 I $2 \mathrm{~A}=$ "having the power of choice": here it is still an adjective, from the secondary meaning of aip $\rho \in \sigma s=$ either a self-chosen party, a sect (Acts $5^{17} \times 5^{5} 24^{5}$ (of Jewish sects), Gal $5^{20}$, I Co $\mathrm{II}^{19}, 2 \mathrm{P} \mathbf{2}^{1}$ (of Christian)), or, self-chosen teaching, heresy (Ign. Eph. 6). Either is possible here. (a) factious (R.V. margin),

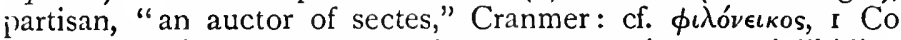
I I" "ambitiosos omnes, præfractos, contentiosos, qui libidine impulsi turbant Ecclesiæ pacem ac dissidia concitant . . . quod nomen, quamvis inter philosophos et politicos homines sit honorificum, merito infame est inter Christianos" (Calvin); or (b) "given to heresie," Tynd., heretical (cf. Tert. de Prcescr. 6). This

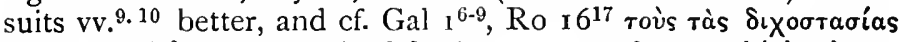

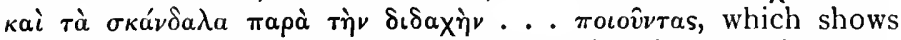
how close the two thoughts lay in St. Paul's mind. This seems the earliest use of the adjective in this sense: it is not found in the Apostolic Fathers, but is frequent in Irenæus and Tertullian, as a substantive $=$ "a heretic," though it still preserved the sense of a "schismatic," cf. Concil. Constant. Canon vi. with Dr. Bright's Note and Suicer, Thes. s.v.

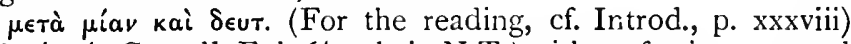

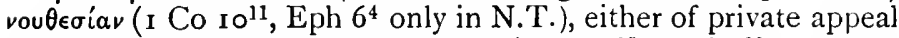
(cf. Acts $20^{31}$ ) or of public censure $\left(2 \mathrm{Th} 3^{15}\right.$, I Ti $\mathrm{I}^{20}$ ). There may be a conscious allusion to Our Lord's command, Mt $\mathrm{I} 8^{15-17}$, and also a reminiscence of the practice of the Jews, under which there was a first admonition of an offending Rabbi lasting for thirty days: then a second for another thirty days: then exconmunication was pronounced (Edersheim, Life and Times of Jesus, ii. p. 183).

тараєтой] a favourite word in P.E. not in the earlier letters: ci. I $\mathrm{Ti}_{4}^{7} 5^{11}, 2$ 'Ti $2^{23}$.

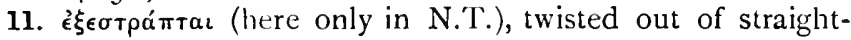




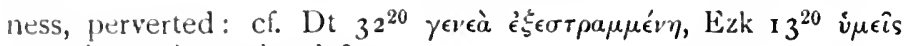
ér.

ápaptáveเ] both as "factious" and as refusing to listen to admonition.

аӥтоката́крьтоs] Condemned "by his own action"; he can be left to God's judgment; cf. Mt $18^{17}$, I Co $5^{12.13}$; perhaps also "by his own conscience," cf. Lk $19^{22}$, Jn $8^{9 \cdot 11}$.

12-15. Cf. Introduction, p. xxxiv ; Harrison, P.E., pp. I 15-18.

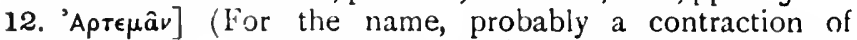
Artemidorus, cf. Pap. Oxyr. iii. 505); according to a later tradition, one of the Seventy and bishop of Lystra. Tuxı́óv of Asia, Acts $20^{4}$, frequently trusted with messages by St. Paul. Eph $6^{21}, \mathrm{Col}_{4}{ }^{7}, 2 \mathrm{Ti}_{4}{ }^{12}$. The contrast with $\mathrm{v}^{13}$ suggests that which. ever came might be meant to take 'Titus' place in his absence, when he left for Nicopolis; cf. $2 \mathrm{Ti} 4^{12}$ note.

Nıкómo $\lambda_{\iota v}$ ] probably Nicopolis in Epirus: a good centre for missionary work in Dalmatia (cf. $2 \mathrm{Ti} 4^{10}$ ) or for a journey to Rome. Here not many years later Epictetus settled and taught his pupils to live a life true to nature, possibly with some 'nowledge of St. Paul's work and writings, but without the knowledge of the saving, enabling grace which would help them to live it.

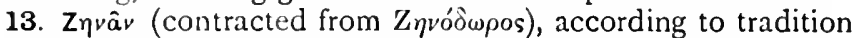
bishop of Diospolis and author of an apocryphal "Acts of Titus."

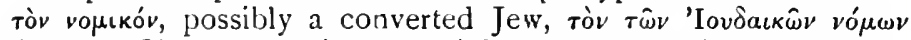

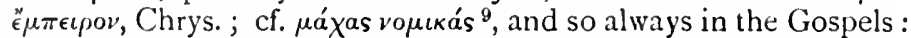
or a Roman lawyer, "jurisconsultum." $\mathrm{H}$ is association with Apollos, a Jew, makes the former more probable.

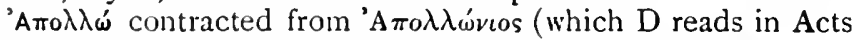

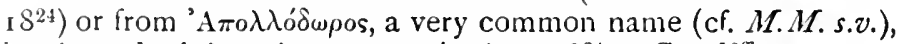
but here doubtless the same as in Acts I $8^{24}$, I Co ${ }^{12 f f}$.

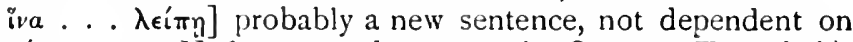
$\pi \rho о \pi \epsilon ́ \mu \psi \nu$ (so Hofmann and apparently Oecum. 'Theophyl.). "See that nothing is wanting to them," cf. $\mathrm{Mk} 5^{23}$ iva $\dot{\epsilon} \lambda \theta \dot{\omega} \nu$

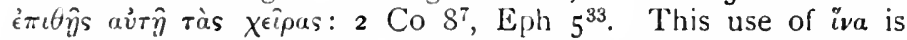

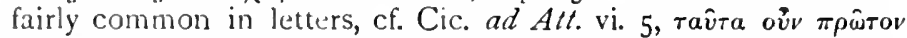

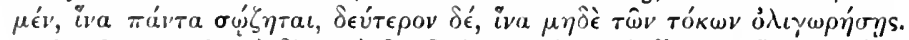

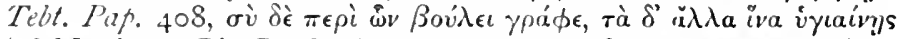
(cf. Moulton, Gk. Gr., Proleg. p. I 76 ; Blass, $\$ 64.4$, M. H. s.v. iva).

14. xai "as well as yourself." Yes, and let all our people be always prepared to help; perhaps also "as well as their pagan

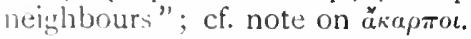

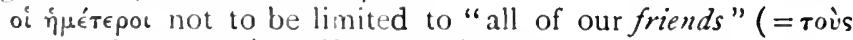

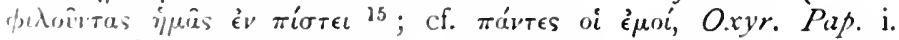
p. I81, "les nótres" of the Port Royalists) as opposed to the false teachers, $1{ }^{10}$ : but $=$ "the whole household of faith," "our brothers and sisters," in contrast to their pagan neighbours : cf. 


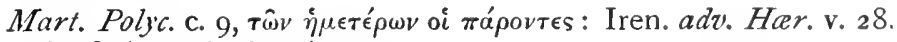

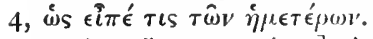

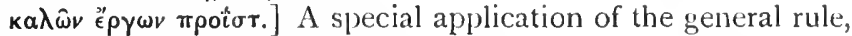
with reference to a new purpose, and here peculiarly applicable to working at trades; $\mathrm{cf}^{8} 8$ note.

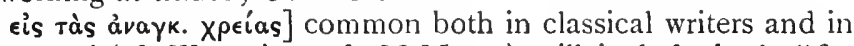
the papyri (cf. Wetstein and M.M. s.v.), will include both "for

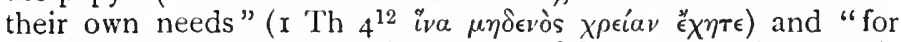

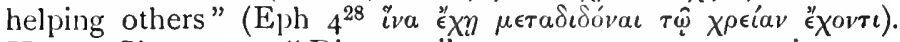
Herm. Sim. x. 4: "Dic omnibus ut non cessent, quicunque (Qy. legendum, "quæcumque") recte facere possunt, bona opera exercere; utile est illis. Dico autem omnem hominem de incommodis eripi oportere"; perhaps a reminiscence of this chapter. A comparison of I 'Th $4^{12}, \mathrm{Eph} 4^{28}$ with this place is very suggestive as to the gradual deepening of Christian motives, the desire of independence, the willingness to help individuals, the desire to be a useful member of society.

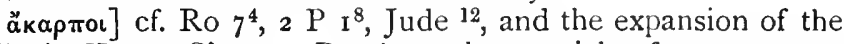
simile in Herm. Sim. 4. But here the special reference seems to be to the Roman taunt that Christians were unprofitable to the State, as keeping apart from many trades, that they were "infructuosi in negotiis," Tert. Apol. 42, and his reply, "Navigamus nos vobiscum et militamus et rusticamur et mercamur: proinde miscemus artes nostras, operas nostras publicamus usui vestro"; cf. notes on ${ }^{3}$ and ${ }^{8}$.

15. oi $\mu \in T^{\prime}$ 'é $\left.\mu \hat{u}\right]$ perhaps "my travelling companions," as no place is mentioned; $\mathrm{cf}$. Gal $\mathrm{I}^{2}$.

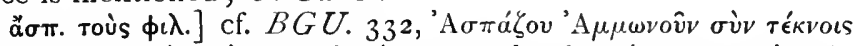

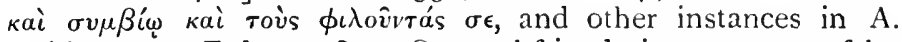
Robinson on Eph., p. 28I. Our real friends in contrast to false teachers, $I^{9} 2^{8}$.

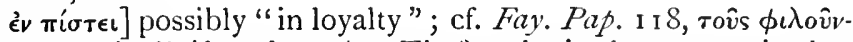
$\tau \alpha \varsigma \dot{\eta} \mu \hat{\alpha} s$ roòs $\dot{\alpha} \lambda \dot{\eta} \theta \iota \alpha \nu$, but $\mathrm{I}^{4}$, I $\mathrm{Ti}^{2}{ }^{2}$ make it almost certain that it is "in a common faith," "in loyalty to Christ."

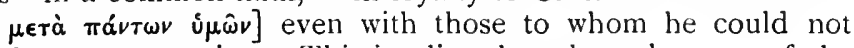
send a warm greeting. This implies that the substance of the letter would become known to the whole church. 



\section{N D E X E S.}

\section{GREEK WORDS.}

áratós, 22.

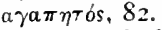

aै $\gamma \gamma \epsilon \lambda o \iota, 46,63$.

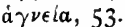

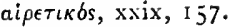

ăкартоs, I 59 .

aे

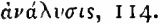

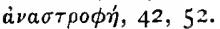

à $\nu \in \pi a i \sigma \chi v \nu \tau o s, 98$.

$\dot{\alpha} \nu \theta \rho \dot{\omega} \pi\llcorner\nu$ os, xxxvi, 35 .

ă $\theta \rho \omega \pi \operatorname{os} \theta \epsilon o \hat{v}, 70$, I II.

$\dot{\alpha} \nu \tau \imath \theta \epsilon \sigma \epsilon \iota s, 76$.

$\dot{a} \nu \tau \iota \lambda a \mu \beta a ́ v \epsilon \sigma \theta a \iota, 66$.

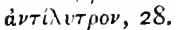

áóparos, 17.

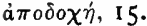

$\dot{a} \sigma \omega \tau i a, 130$.

ai่fáôns, I 30 .

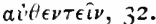

aن่та́ $\rho \kappa \epsilon \iota a, x v, x v i, 6 S$.

$\beta a \theta \mu o ́ s, 4$ I.

Гахаті́, хххvii. II7.

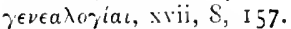

$\gamma$ үá $\mu \mu \alpha \tau a$, IO9.

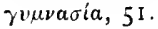

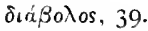

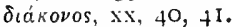

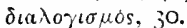

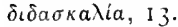

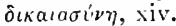

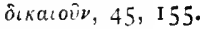

óitoros, 40.

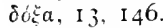

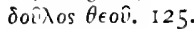

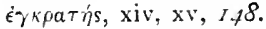
$\epsilon \kappa \lambda \epsilon \kappa \tau$ oi, $63,95,125$.
E $\lambda \pi$ is, 5 .

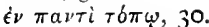

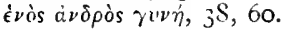

है $\nu \tau \epsilon \nu$ है

$\epsilon^{2} \pi i \gamma \nu \omega \sigma \iota s \dot{\alpha} \lambda \eta \theta \epsilon i a s, 27$.

є̇

$\dot{\epsilon} i \sigma \kappa o \pi$ os, xix, xxiii, 35 .

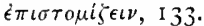

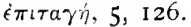

Ė

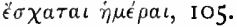

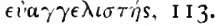

$\epsilon$ i' $\epsilon$ $\gamma \epsilon \sigma i a, 66$.

$\epsilon \dot{v} \sigma \epsilon \beta \epsilon \iota a, 26,44,58$.

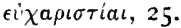

$\zeta \omega \gamma \rho \epsilon \hat{\imath \nu}, \mathrm{IO} 2$.

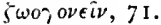

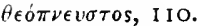

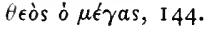

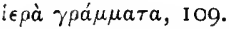

iє $\rho \circ \pi \rho \epsilon \pi \dot{s}$, xiv, I 4 O.

'Inoốs Xiforós, xxi, 5, I6, 94.

iva, $15 \mathrm{~S}$.

каıроis ioiots, 72, 126.

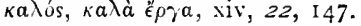

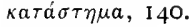

$\kappa \nu \dot{\eta} \theta \epsilon \iota \nu$, I I 3 .

kolvwvitós, 74.

$\kappa o ́ \sigma \mu \iota s, \mathrm{xiv}, \mathrm{xvi}, 3 \&$.

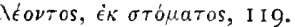

入óros $\theta \epsilon o \hat{1}, 48,155$.

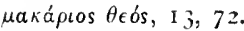

$\mu \epsilon \sigma i \tau \eta s, 28$

uıâs ruvaıkòs àvíp, 36 .

$\mu$ î $\theta 0$, xvii, 8, I 35 . 
l'ébutos, xxix, 39.

vp

oin ovcuia $\forall \in o \hat{,} 9$.

ontlotoutiv, 99 .

$\pi a_{i} \hat{)} \in i \epsilon \iota \nu, x v, 144$.

$\pi a \backslash \gamma, \in \nu \in \sigma i a, 154$

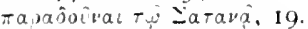

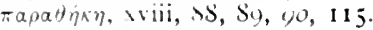

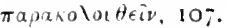

Taposvos, 1 jo.

$\pi$ eploúolos, 147.

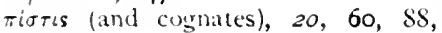
I 14 .

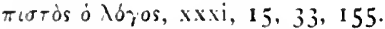

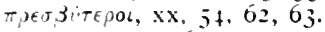

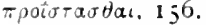

трофитеí, 19,54 .

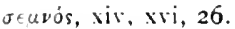

जरe $\pi$ av $\mu a, 6$ ?

$\sigma \pi a r a \backslash a ̀ v, 5 S$.

vTEvôual, 114

"Tésua Ja.36\%, 95.

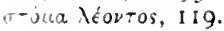

orpateia, IS.

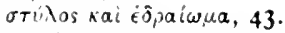

$\sigma \omega \tau \dot{\eta} \rho, 5,5 \mathrm{~s}$.

$\sigma \dot{\omega} \phi \rho \omega \nu$ (and cignales), xir, xv, $3 \mathbf{1}$,

33. $39,86,140,1+5$.

TEห⿻orovia, 32 .

$\tau \iota \mu \bar{\nu} \nu, 57,02$.

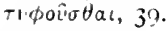

irvaivew, xiv, xvi, 12, 139.

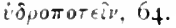

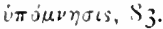

ілтотаүฑं, 32 .

in от í $\omega \sigma$ s, 16.

pac入óvi?s, I I $S$.

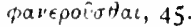

$\phi$ i $\backslash \alpha \nu \theta p \omega \pi i a$, I 53 .

$x \in \iota \rho \hat{\nu} \nu \dot{\epsilon} \pi \imath \theta \epsilon \sigma เ s, 54,63, S_{j}$.

$\chi \bar{\eta} \rho a \iota, x x, x \times v i, ; 0$.

Xiprotós, z'. 'Inoais.

xpóvoเ aísvเot, $\$ 7,126$.

$\dot{\omega} y \dot{\epsilon} \sigma \tau t, x x x i, 19,99$.

\section{SUBJECTS ANI NAMES.}

Abrahame, I., 25, 37, 68, 74 .

Agrapha, xxiii, 62, 68, 101, 108, 135 , 155.

Anacolutha, 7 .

Apocalyptic (Jewish, 105.

(Christian), 47 .

Apocrypha (Jewish), 33, 100, 107

Baptism, xviii, 154.

lishops, xx, xxiii, 35, 129.

Character, Chrintian, xiii. 41.

, Cretan, 122, 1,32, 151.

.. St. l'aul, xxт1, 16, if 2.

,. Timolhy, xxy.

," lilus, xxi, $1,:$

(mintom, l)e Sacertolzo, xl, 7, 56, 6 , 103 .

(ituren life, xiv, 25,151 .

(reet. germs of, 45, 71, 95.

1) coacuns, xx.

biliche. sxxix.

1) nciplane, xuiii, 19, 6 I, 157 .

1) wurce, 37 .
Epictetus, xr, 18, 27, 54, 65, 69, 87, $9 j, 101$.

Epimenides, 134.

Excommunication, 19.

Family life, xiv, xxv, xxvii, 39, 55, $58,1,3 \mathrm{~s}$.

Cialatia, 117 .

Gousticism, xvii, xxiii, sxri, 9, 24 , $47,76,99$.

Gospels, relation to, xxiii.

God, titles of, xxi, 13, 17, 52, 73, 125.

Grace before meat, 49.

Greek Proverls, $4 \$$, 69.

Gregory, Regula fastoralis liber, xli.

Ilippolytus, Canons of, $x$ l.

llomer, 48 .

llymns, xxiv, 42,96 .

Inspiration, I 10.

Jannes and Jambres, 107. 
Johannine phrases, xxiv, 15,45,48, Riches, right use of, 69, 73, 75 .

155.

Iudaism, xvii, 8, 47, 133 .

Law, function of, $\mathrm{II}$.

Laying on of hands, $54,63,85$.

Lord's Prayer, i I6, I 20.

Roman Emperor, prayer for, 25.

$72,86,95,120,145$.

worship of, xxii,

Rose, H. J., v.

Salvation, 27, 52 .

Scripture, purpose of, I09, 1 I0.

Man of God, 7o, I I I.

Marcion, xiii, xxiii, xxvi, 76 .

Marcus Aurelius, xvi, xviii, I13, I40.

Married life, $36,3^{8}, 48,60$.

Mysteries, 6, I $8,2 S, 44,145$, I 54.

Order of composition, xxxiv.

Ordination, xix, $3,18,54,63,85$, 129.

Oxymoron, xxviii, 59 .

Penitence, 16.

I Peter, relation to, xxiv.

Play on cognate words, xxviii.

Prayer for all men, 25.

,, for rulers, 25 .

" for the dead, 90.

Presbyters, xx, 54, 62, 129.

Prophecy, xviii, I 8, 47, 54 .

Psalm xxii, I 16.

Rendel IIarris, I 34 .

Resurrection, $96,99$.

, reading of, 53 .

Secular trades, 93.

Self-condemnation, 16.

Self-praise, I1 2, I I 4.

Servant of Jehovah, IoI.

Services, Church, xviii, $23,29,53,5^{9}$.

Shechinah, $13,146$.

Slavery, I $2,65,66,142$.

Spirit, the lloly, xxii, S9.

Stricism, xv, xvi, 36, 140,154 .

Style, xxvii.

" clausula of sentences, $v$.

Teacher, the Christian, 2, 78 .

, in face of death, 79 .

Torm, F., xxviii.

Traherne's . Neditations, 5r, 69, 74 .

Turner, C. Il., xxxi, xxxv, 54.

V'icarious sacrifice, 28.

Widows, xx, xxvii, 56 .

Women, ministry of, $x x, 29,31$.

(See also pp. ix-xi, and $x$ li-xliv.) 



Lock, Walter.

Pastoral epistles.
BS

491

. 16 v. 39 
